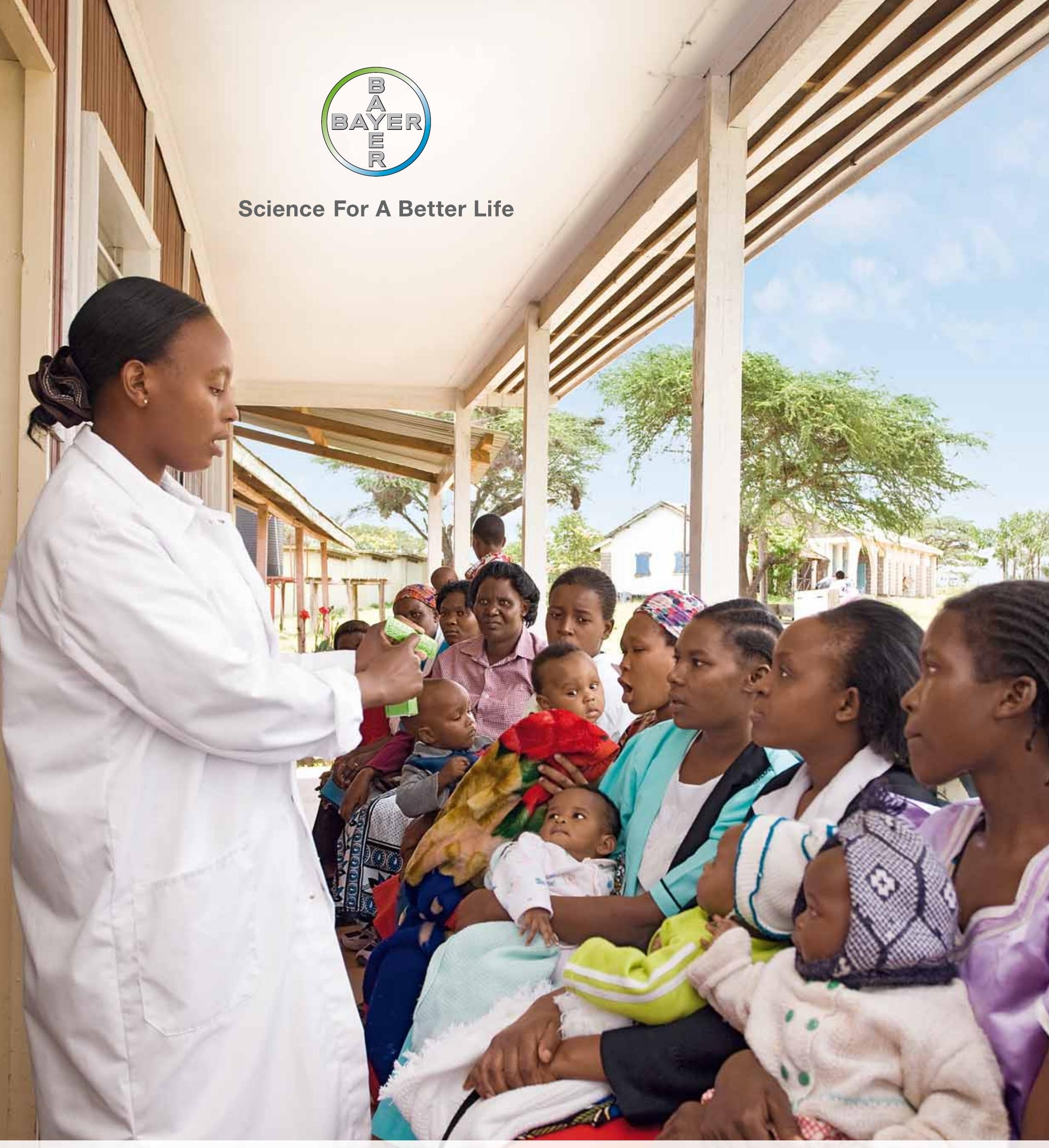

\title{
Sustainable Development Report
}

2009

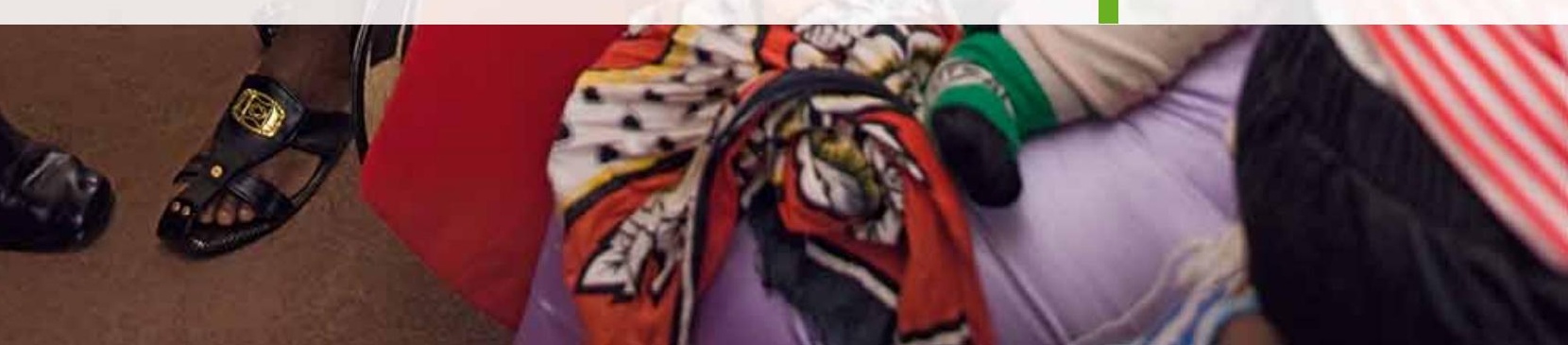




\title{
Sustainable Development Report 2009
}

\author{
With our Sustainable Development Report we would like to give our stakeholders a \\ transparent and comprehensive description of the economic, ecological and social \\ challenges that are linked to our operations and show them the strategies and solutions \\ that we are applying to meet them.
}

This publication is aimed at business partners, employees, stockholders, non-governmental organizations, suppliers, authorities and the general public. The concerns of our stakeholders form the basis of our reporting and our sustainability strategy, which we updated in 2009.

With this strategy we set the focus of our sustainability commitment on health care, security of food supply and climate and resource protection. These are the areas in which we can provide the most efficient and effective approaches as they reflect our fields of expertise. At the same time they have a high social relevance to our company. We feature detailed information on the Bayer sustainability strategy and its new areas of focus in the "Strategy \& Management" section and in the focus issue articles. You can find up-to-date information on the subject of water featured as a focus issue last year in the "Ecology" section.

Our Performance Report gives an overview of all other facts and figures that are relevant to sustainability management in the Group, allowing the reader quick and easy access to data on our Group-wide sustainability performance.

In this Sustainable Development Report we have endeavored to ensure maximum transparency, clarity of layout and ease of verification. The statements pro- vided here apply to all sites and activities of the Bayer Group. All data in the focus issue articles and in the Performance Report were subjected to an assurance process by Ernst \& Young (see page 113).

The report is published in German, English and Spanish. The editorial deadline was April 30, 2010. Our next Sustainable Development Report is due to be published in 2011.

Designations such as manager and employee refer equally to men and women; the masculine form of personal pronouns is used in such cases solely to simplify the text.

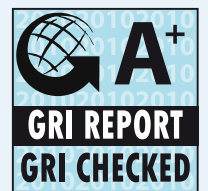

An important orientation for our reporting is provided by the guidelines of the Global Reporting Initiative (GRI), with which, in this report, we comply fully. The GRI has checked and confirmed that level A+, the highest reporting level, has been maintained. An index at the end of the report lists the pages on which information is provided on the individual GRI indicators.

\section{WWW Further information on the Internet}

The report is supplemented by further information given on our website. The report contains references to enable easier access: at www.sustainability2009.bayer.com you will find a page entitled "Additional Info Links." Here, all references are listed with a corresponding code number. By clicking on these you will go to the desired information. 


\begin{tabular}{|c|c|c|c|}
\hline \multirow{2}{*}{\multicolumn{4}{|c|}{ Bayer Group }} \\
\hline & & & \\
\hline Sales & 32,918 & 31,168 & -5.3 \\
\hline$\overline{\text { EBITDA }^{1}}$ & 6,266 & 5,815 & -7.2 \\
\hline EBITDA before special items & 6,931 & 6,472 & -6.6 \\
\hline EBITDA margin before special items & $21.1 \%$ & $20.8 \%$ & \\
\hline$\overline{\mathrm{EBIT}^{2}}$ & 3,544 & 3,006 & -15.2 \\
\hline EBIT before special items & 4,342 & 3,772 & -13.1 \\
\hline Income before income taxes & 2,356 & 1,870 & -20.6 \\
\hline Net income & 1,719 & 1,359 & -20.9 \\
\hline Earnings per share $(€)^{3}$ & 2.22 & 1.70 & -23.4 \\
\hline Core earnings per share $(€)^{4}$ & 4.17 & 3.64 & -12.7 \\
\hline Gross cash flow ${ }^{5}$ & 5,295 & 4,658 & -12.0 \\
\hline Net cash flow ${ }^{6}$ & 3,608 & 5,375 & +49.0 \\
\hline Net financial debt & 14,152 & 9,691 & -31.5 \\
\hline Capital expenditures as per segment table in the Annual Report 2009 & 1,982 & 1,669 & -15.8 \\
\hline Research and development expenses & 2,653 & 2,746 & +3.5 \\
\hline Dividend per Bayer AG share $(€)$ & 1.40 & 1.40 & 0.0 \\
\hline \multicolumn{4}{|l|}{ Bayer HealthCare } \\
\hline Sales & 15,407 & 15,988 & +3.8 \\
\hline EBITDA $^{1}$ & 3,692 & 4,148 & +12.4 \\
\hline EBITDA before special items & 4,157 & 4,468 & +7.5 \\
\hline EBITDA margin before special items & $27.0 \%$ & $27.9 \%$ & \\
\hline $\mathrm{EBIT}^{2}$ & 2,181 & 2,640 & +21.0 \\
\hline EBIT before special items & 2,764 & 3,012 & +9.0 \\
\hline Gross cash flow ${ }^{5}$ & 3,045 & 3,153 & +3.5 \\
\hline Net cash flow ${ }^{6}$ & 2,259 & 3,431 & +51.9 \\
\hline \multicolumn{4}{|l|}{ Bayer CropScience } \\
\hline Sales & 6,382 & 6,510 & +2.0 \\
\hline$\overline{\text { EBITDA }^{1}}$ & 1,450 & 1,311 & -9.6 \\
\hline EBITDA before special items & 1,603 & 1,508 & -5.9 \\
\hline EBITDA margin before special items & $25.1 \%$ & $23.2 \%$ & \\
\hline $\mathrm{EBIT}^{2}$ & 918 & 798 & -13.1 \\
\hline EBIT before special items & 1,084 & 1,017 & -6.2 \\
\hline Gross cash flow 5 & 1,192 & 1,043 & -12.5 \\
\hline Net cash flow 6 & 736 & 745 & +1.2 \\
\hline \multicolumn{4}{|l|}{ Bayer MaterialScience } \\
\hline Sales & 9,738 & 7,520 & -22.8 \\
\hline$\overline{\text { EBITDA }^{1}}$ & 1,041 & 341 & -67.2 \\
\hline EBITDA before special items & 1,088 & 446 & -59.0 \\
\hline EBITDA margin before special items & $11.2 \%$ & $5.9 \%$ & \\
\hline $\mathrm{EBIT}^{2}$ & 537 & (266) & $\cdot$ \\
\hline EBIT before special items & 586 & (126) & •. \\
\hline Gross cash flow ${ }^{5}$ & 850 & 319 & -62.5 \\
\hline Net cash flow ${ }^{6}$ & 782 & 849 & +8.6 \\
\hline
\end{tabular}

1 EBITDA: EBIT plus amortization of intangible assets and depreciation of property, plant and equipment. EBITDA, EBITDA before special items and EBITDA margin are not defined in the International Financial Reporting Standards and should therefore be regarded only as supplementary information. The company considers underlying EBITDA to be a more suitable indicator of operating performance since it is not affected by depreciation, amortization, write-downs/write-backs or special items. The company also believes that this indicator gives readers a clearer picture of the results of operations and ensures greater comparability of data over time. The underlying EBITDA margin is calculated by dividing underlying EBITDA by sales.

ensures greater comparability of data ove
EBIT as shown in the income statement

3 Earnings per share as defined in IAS $33=$ net income divided by the average number of shares

3 Earnings per share as defined in IAS 33 = net income divided by the average number of shares picture of the results of operations and ensures greater comparability of data over time.

5 Gross cash flow = income from continuing operations after taxes, plus income taxes, plus non-operating result, minus income taxes paid or accrued, plus depreciation, amortization and write-downs, minus write-backs, plus/minus changes in pension provisions, minus gains/plus losses on retirements of noncurrent assets, plus non-cash effects of the remeasurement of acquired assets. The change in pension provisions includes the elimination of non-cash components of the operating result. It also contains benefit payments during the year.

6 Net cash flow = cash flow from operating activities according to IAS 7 


\section{Bayer}

Bayer AG defines common values, goals and strategies for the entire Group. The subgroups and service companies operate independently, led by the management holding company. The Corporate Center supports the Group Management Board in its task of strategic leadership.

\section{Bayer HealthCare}

Bayer HealthCare is among the world's foremost innovators in the field of pharmaceutical and medical products. This subgroup's mission is to research, develop, manufacture and market innovative products that improve the health of people and animals throughout the world.

\section{Bayer CropScience}

Bayer CropScience, with its highly effective products, pioneering innovations and keen customer focus, holds global leadership positions in crop protection and non-agricultural pest control. The company also has major activities in seeds and plant traits.

\section{Bayer MaterialScience}

Bayer MaterialScience is a renowned supplier of high-tech polymers and develops innovative solutions for a broad range of applications relevant to everyday life. Products holding leading positions on the world market account for a large proportion of its sales.

\section{SERVICE COMPANIES}

\section{Bayer Business Services}

Bayer Business Services is the Bayer Group's global competence center for IT-based services. The focus of this company's offering is on integrated services in the core areas of IT infrastructure and applications, procurement and logistics, human resources and management services, and finance and accounting.

\section{Bayer Technology Services}

Bayer Technology Services, the global technological backbone and a major innovation driver of the Bayer Group, is engaged in process development and in process and plant engineering, construction and optimization.

\section{Currenta}

Currenta offers services for the chemical industry including utility supply, waste management, infrastructure, safety, security, analytics and vocational training. 


\title{
Working to create value through innovation and growth
}

\author{
Bayer is a global enterprise with core competencies in the fields of health care, nutrition \\ and high-tech materials. Our products and services are designed to benefit people and \\ improve their quality of life. At the same time we want to create value through innova- \\ tion, growth and high earning power.
}

We are firmly aligned to our mission statement "Bayer: Science For A Better Life" and continue to optimize our portfolio, concentrating our activities in three high-potential, efficient subgroups with largely independent operations: HealthCare, CropScience and MaterialScience. These provide us with access to major global growth markets and are supported by our service companies.

As an inventor company, we plan to continue setting trends in research-intensive areas. Innovation is the foundation for competitiveness and growth, and thus for our company's success in the future.

Our knowledge and our products are helping to diagnose, alleviate or cure diseases, improving the quality and adequacy of the global food supply, and contributing significantly to an active, modern lifestyle. Our expertise and innovative capability also enable us to offer solutions for protecting the climate and addressing the consequences of climate change.
We are committed to the principles of sustainable development, and to our role as a socially and ethically responsible corporate citizen. For us, there is a clear link between technical and economic expertise and corporate social responsibility. This, in turn, we define as our responsibility to work for the benefit of humankind, become socially involved and make a lasting contribution to sustainable development. At Bayer, we regard economy, ecology and social commitment as objectives of equal rank.

We seek to retain society's confidence through performance, flexibility and open communication as we work in pursuit of our overriding goals: to steadily create corporate value and generate high value-added for the benefit of our stockholders, our employees and the community in every country in which we operate. 
Foreword by Bayer Management Board Chairman Werner Wenning

News 2009/2010

The company

Subgroups and service companies

Strategy and Management

Our sustainability management

Step-by-step development of sustainability in the company 25

Interview with Management Board member Dr. Wolfgang Plischke 26

Bayer in dialogue with its stakeholders

\section{Focus Issues}

Economics

Employees

Human rights

Corporate social responsibility

Product stewardship

Financial calendar

Global Compact 
Alliances for health 30

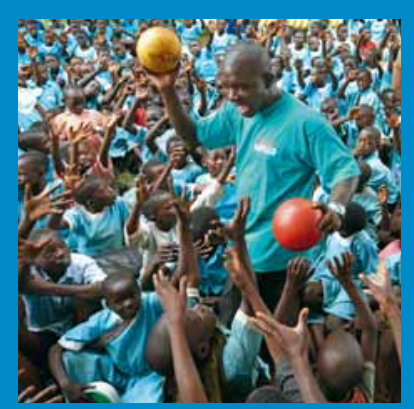

Controlling population growth

in developing and emerging

countries and stemming tropical and neglected diseases in these countries are the main objectives of our alliances for health - alongside measures to ensure fair access to medicines worldwide.

\section{Partnerships for good harvests 36}

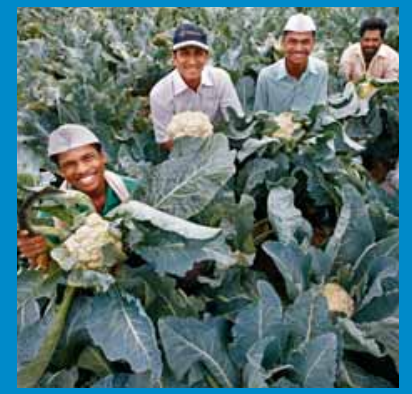

Demand for foodstuffs is growing and consumer behavior is changing: with innovative, sustainable solutions from sowing to the harvest and in partnership with farmers and other key players along the entire food chain, we are working toward the goal of high-quality food for all.

\section{Climate program takes effect $\quad 42$}

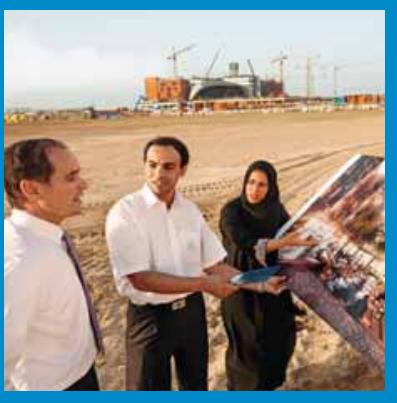

Innovative materials for energyefficient building are playing a key role in protecting the climate. In addition, intelligent measuring tools that we have developed are also helping to enable a responsible use of resources. 


\section{Sustainable and successful business practices}

\section{Dear reader:}

Sustainable business practices have long been a prime goal of corporate policy in our Group - a policy that has also proven its worth in the global financial and economic crisis. This has brought us success in what has been a difficult environment.

Our strategy is focused on global megatrends and related issues such as health care, reliable food supplies, energy efficiency and climate protection. We align our product portfolio and our commitment to sustainability to these future-related topics by offering innovative strategies, products and solutions in the fields of health care, nutrition and high-quality materials. One of our key objectives is to balance economic growth with environmental and corporate social responsibility. We are also staunch supporters of the objectives of sustainable development and are committed to the principles of the UN Global Compact.

We are focused on making sustainability a reality on three levels - through our products and innovations, which are designed to benefit humankind and help improve people's quality of life; through our business activities, by acting responsibly toward all our interest groups; and finally through our corporate social responsibility commitment, which includes around 300 projects worldwide and numerous sponsorship activities by our two foundations.

With this in mind, we built on our sustainability strategy last year and launched the integrated Bayer Sustainability Program. This focuses on three core areas - strong alliances for sustainable health care, innovative partnerships to provide more high-quality food, and new solutions for climate protection and resource use.

We are incorporating the company's products and its employees' know-how into eight international lighthouse projects to continue driving sustainable development forward in many parts of the world. These projects are a shining example of our commitment and a concrete illustration of the partnership principle.

Sustainability essentially means ensuring future viability. And our innovations play no small part of this. That's why, as in the past, we will continue to make substantial investments in research and development this year and maintain our R\&D budget at a record €2.9 billion.

The principles of sustainable development are also firmly established in our Corporate Compliance Policy, a set of rules that makes legal compliance and Responsible Care mandatory for every Bayer employee. We have reinforced this by arranging for non-compliance with our policy to affect the variable remuneration component for our senior management, the Global Leadership Circle.

We launched a Group-wide initiative on process and plant safety at the start of 2010 with the goal of driving forward our Bayer systems and our commitment to safety in an even more targeted way. We set out the key principles and organizational structures in the Group Directive on Process and Plant Safety. 
Werner Wenning,

Chairman of the Board of Management of Bayer AG

A further top priority for us is maintaining diversity in our staffing, including equal opportunities for men and women. We have continuously increased the percentage of women in senior management positions in the last few years, for example. Yet the current figure of 5.5 percent means we still have some way to go. Specialist and personal skills and professional experience are crucial in the staff selection process, and a quota system would run counter to this. That's why we remain committed to targeted programs to promote women. By appointing a woman as CEO of Bayer CropScience, we have sent a clear signal that women at Bayer can reach top positions.

We also expect sustainable development from our suppliers. In 2009, we therefore adopted and communicated our Supplier Code of Conduct. This details the criteria according to which we evaluate and select suppliers.

We place particular emphasis on our foundation activities. The Bayer Science \& Education Foundation, for example, not only promotes projects to improve science teaching in schools, it also supports students and recognizes scientists for outstanding research work.

Our commitment has been rewarded through numerous awards and excellent ratings by independent institutions. For example, in 2009 we were included in the Carbon Disclosure Leadership Index as the world's best company based on our transparent reporting. Bayer is also listed in the Dow Jones Sustainability World Index, one of the leading global sustainability indexes.

All of this underlines the fact that we want to achieve sustainability in everything that we do. Our contributions are many and varied, yet they serve a single goal, as expressed by our mission statement: "Science For A Better Life."

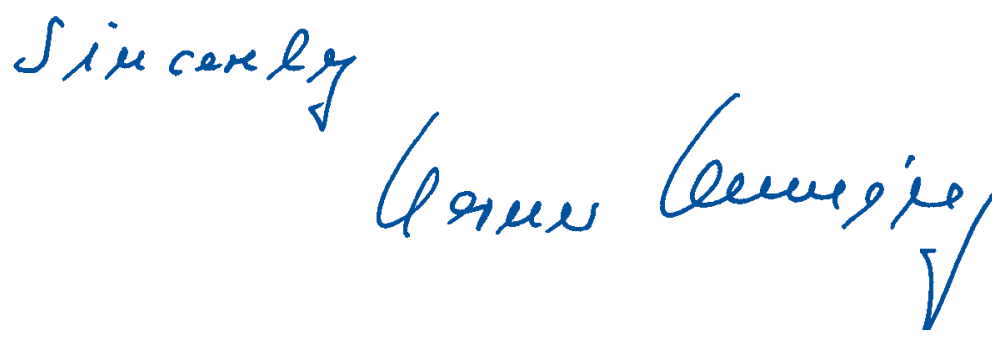




\section{Bayer researchers win the German Future Prize}

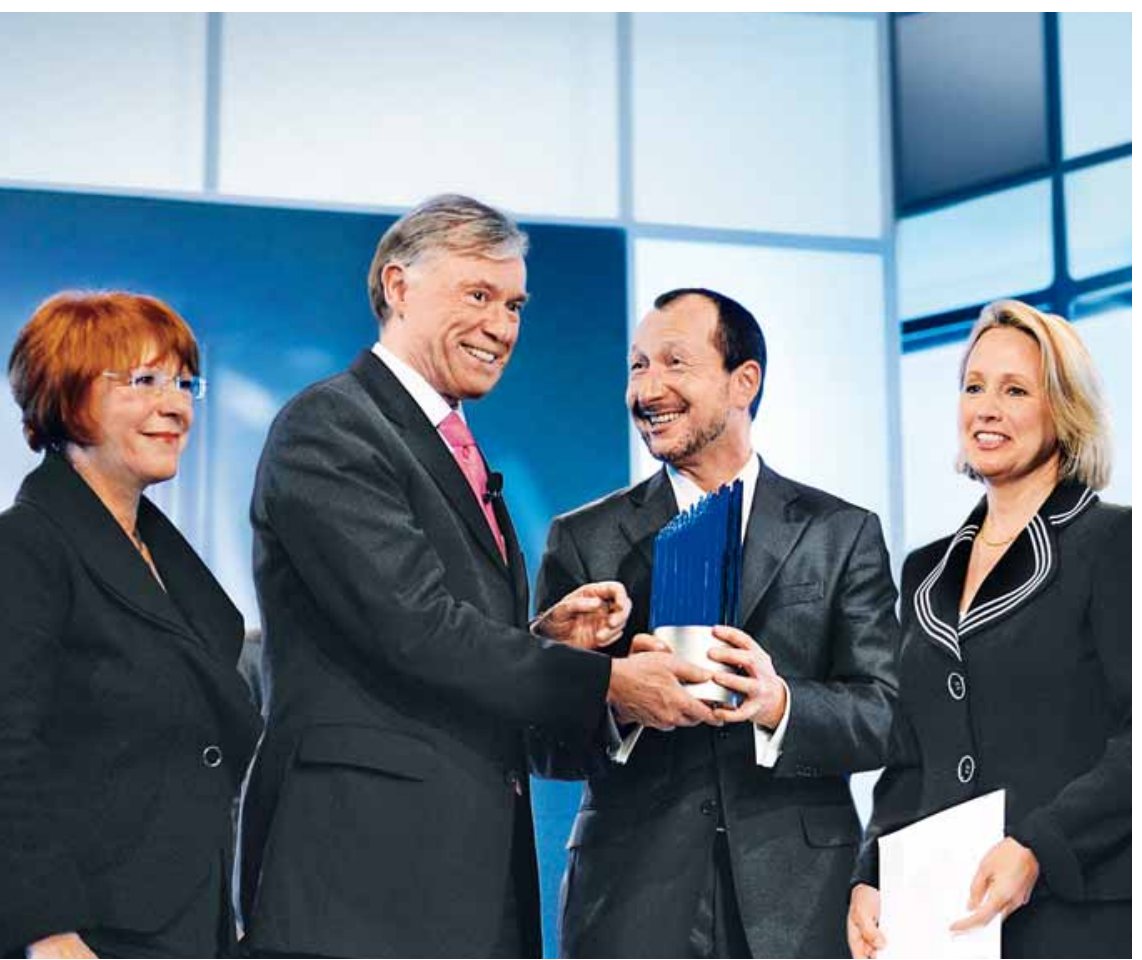

Award for top research: German President Horst Köhler (second from left) presents the German Future Prize 2009 to Bayer researchers

Dr. Elisabeth Perzborn (left), Dr. Frank Misselwitz (second from right) and Dr. Dagmar Kubitza.
The German Future Prize 2009, awarded by the country's Federal President, went to an R\&D team from Bayer: Dr. Frank Misselwitz, Dr. Elisabeth Perzborn and Dr. Dagmar Kubitza received the prize for achievements in technology and innovation from President Horst Köhler at a ceremony in Berlin. The Bayer scientists from Wuppertal were honored with this prestigious award for the development of the new anticoagulant drug rivaroxaban (Xarelto ${ }^{\circledR}$ ). Thromboembolism is a life-threatening disorder which affects millions of people every year - often with a fatal outcome. In the western world, venous thromboembolism kills more than twice as many people as breast cancer, prostate cancer, HIV/Aids and road traffic accidents combined. Rivaroxaban is an anticoagulant with a novel mechanism of action. The active substance selectively targets a pivotal stage in the blood clotting process and inhibits the activity of the enzyme Factor xa, which plays a key role in the development of thrombosis. Rivaroxaban offers patients and doctors major advantages over the current standard therapies. Studies have shown rivaroxaban to be particularly effective in preventing venous thromboembolism following elective hip and knee replacement surgery in adults. Moreover, rivaroxaban is administered in tablet form and does not have to be injected like the current standard therapies.
Future-focused

\section{project to protect the climate}

Together with SBM Offshore, Bayer MaterialScience is planning a particularly innovative project on climate protection: the two companies want to develop a flexible wave energy converter for use in the Atlantic. With this technology, the previously unused resources of the seas are to be harnessed for environmentally friendly energy generation. The World Energy Council estimates that global wave energy resources are equivalent to about double the total quantity of electricity currently generated throughout the world. This new technology will be of particular interest to utility companies looking to expand their renewable energy portfolios. In 2015, there are plans to build a power plant on the open sea.

\section{High-quality fruit and vegetables}

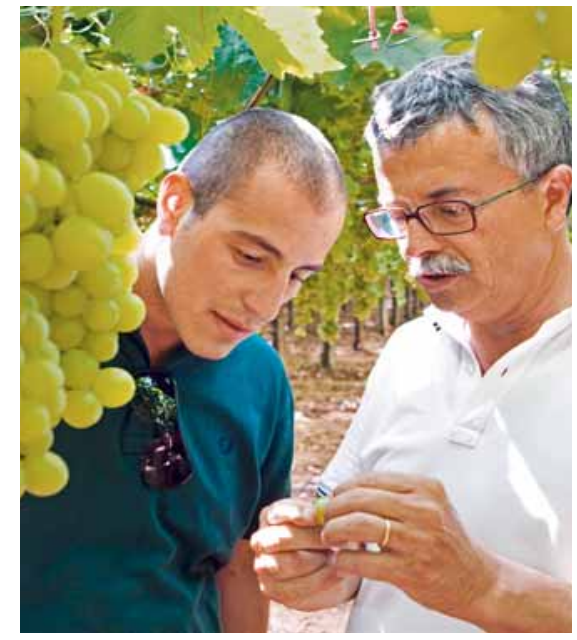

Focus on quality: through close cooperation with their suppliers, Giuseppe Cortese (left) und Angelo Marazia from Bayer CropScience help to improve quality in the vineyards.
As part of its Food Chain Partnership project, Bayer CropScience has signed a global cooperation agreement with The Greenery B.v., an international trading company specialized in the marketing of vegetables, fruit and mushrooms, based in The Netherlands. The agreement complements the 30 existing Food Chain Partnership projects in Central and South America, Europe, Africa and Asia. It has advantages for both consumers and producers: consumers have access throughout the year to high-quality produce for a healthy diet, while the producers are supported and advised by Bayer CropScience in the implementation of optimized crop protection programs (see also page 36 ). 


\section{Safety with nanotechnology}

In September 2009, Bayer MaterialScience received regulatory approval from the U.S. Environmental Protection Agency (EPA) for Baytubes ${ }^{\circledR}$, its multi-walled carbon nanotubes (CNT). The addition of Baytubes ${ }^{\circledR}$ improves the mechanical stability and antistatic properties of polymers. Typical areas of application include rotor blades for wind power plants and sports articles such as skis. CNTs can also be used for an innovative safety technology that significantly reduces the risk of explosions in fuel tanks. For this purpose, Bayer MaterialScience has concluded an exclusive cooperation and supply agreement for Baytubes ${ }^{\circledR}$ with Hirtenberger PROSAFE Safety Technology GmbH (HPST), Hirtenberg, Austria. HPST is to use the Bayer MaterialScience product in the manufacture of newly developed special spheres designed to prevent the formation of explosive gas mixtures in fuel tanks.

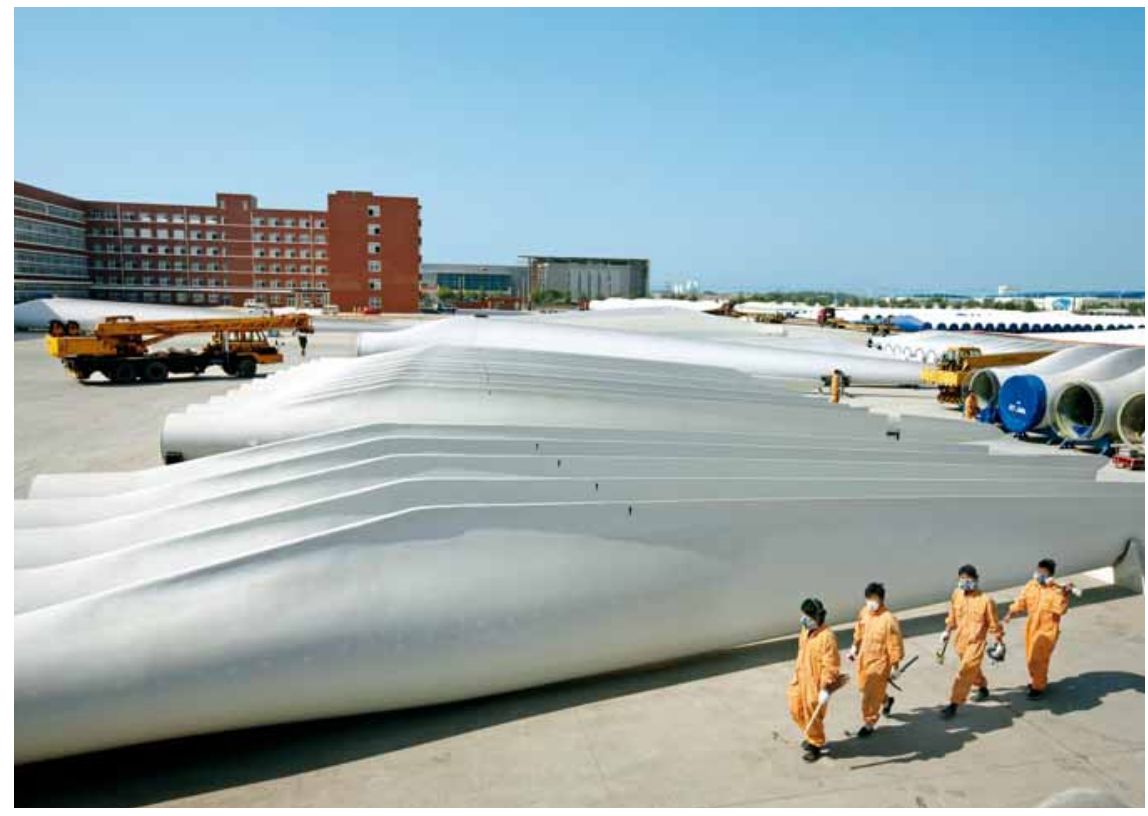

Safety through Baytubes ${ }^{\circledR}$ : carbon nanotubes not only improve the stability of rotor blades (above) in wind power plants, they also increase the safety of fuel tanks.

\section{Progress with Nexavar in new indications}

Bayer HealthCare and Onyx Pharmaceuticals have launched a Phase III study with Nexavar ${ }^{\circledR}$ for patients with locally advanced or metastatic differentiated thyroid cancer. The study observes patients with thyroid cancer who no longer respond to the usual treatment with radioactive iodine. The drug has also demonstrated positive effects in breast cancer: a combination therapy of Nexavar ${ }^{\circledR}$ with the oral chemotherapy agent capecitabine extended progression-free survival in patients with advanced breast cancer by 74 percent in an independent Phase II study. A further Phase II study with Nexavar ${ }^{\circledR}$ and paclitaxel indicated a positive trend in the combination arm. Further analyses are necessary here.

The drug is already approved in more than 90 countries to treat liver cancer and for the treatment of kidney cancer. The drug is also being evaluated by Bayer and Onyx, government agencies, oncological study groups and individual investigators as a single-agent or combination treatment in a wide range of other cancers.

\section{Our challenges}

\section{Cases concerning traces of genetically modified rice}

In lawsuits concerning genetically modified rice, rice farmers in the United States allege that they have suffered financial losses as a result of traces of precommercial genetically modified rice from Bayer CropScience that were discovered in the harvest in 2006. In two lawsuits in December 2009 and February 2010, a court in Missouri decided that Bayer had to pay compensation amounting to a total of approximately us\$3.5 million to five agricultural plaintiffs. In a third case in February 2010, a court in Arkansas sentenced Bayer to pay total compensatory and punitive damages of us\$1 million. In a fourth lawsuit in February 2010, a court in Arkansas ordered Bayer to pay compensatory and punitive damages of around US\$48 million in total to 14 rice farmers. Bayer disagrees completely with the findings of liability and the awards of compensatory and punitive damages, and will appeal the decisions.

\section{Patent infringement taken to court}

Bayer has taken the Indian pharmaceutical company Lupin to court in the United States for patent infringement. Lupin applied for regulatory approval in the United States for a special formulation - a liquid for oral administration - of the broad-spectrum antibiotic Cipro ${ }^{\circledR}$, for which patent protection runs until 2015.

\section{Dispute with generics specialist in India}

In February 2010, a court in New Delhi, India, rejected Bayer's plea to prevent approval of a generic version of its patented cancer drug Nexavar ${ }^{\circledR}$. Indian generics company Cipla had filed for registration even though Nexavar ${ }^{\circledR}$ has patent protection until 2020. Bayer has appealed to the Supreme Court and sued Cipla for patent infringement. 


\section{Bayer strengthens sustainability commitment}

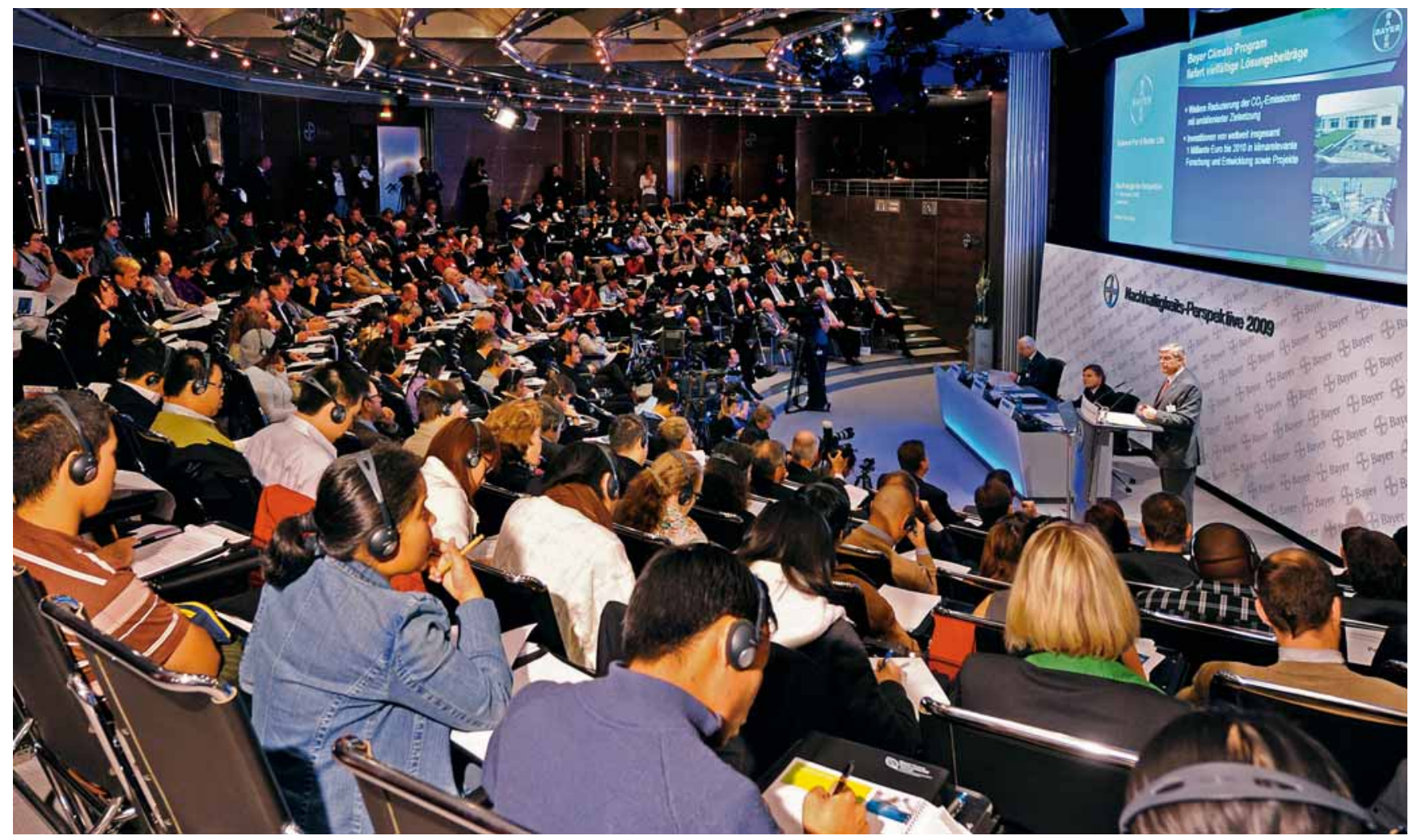

Bayer is increasing its commitment to sustainability. To this end, the Group has launched an extensive program with eight lighthouse projects focusing on the fields of health care, nutrition and climate protection. Its objective is to integrate the company's products and its employees' know-how into international projects to promote sustainable development right across the globe. Chairman of the Bayer Board of Management Werner Wenning and Board member Dr. Wolfgang Plischke presented the Bayer Sustainability Program at a news conference in Leverkusen attended by approximately 120 journalists from 35 countries. More than 15 million people worldwide will benefit directly from the lighthouse projects that serve as the centerpiece of the Sustainability Program. In addition, by 2013, the Group aims to increase energy efficiency in production by 10 percent compared with 2008, corresponding to an annual reduction
International news conference in the packed Bayer Communications Center in Leverkusen: Bayer CEO Werner Wenning (at the lectern) and Management Board member Dr. Wolfgang Plischke (on the podium at left) explained the new Sustainability Program to journalists.

of 350,000 metric tons of greenhouse gas emissions. Furthermore, through a new technology for chlorine production, it will be possible to lower annual greenhouse gas emissions by a further 250,000 metric tons through 2020. Bayer's business activities are focused on sustainability. According to Wenning, "sustainable development forms an integral part of Bayer's corporate policy, which is geared toward highquality solutions and long-term success." You can read more about the company's Sustainability Program on page 18 and in the sections on the focus issues of health, nutrition and climate protection, starting on page 30 .

\section{Investing in the growing market of medical technology}

Bayer MaterialScience (BMS) is helping to support the growing demand for innovative medical technology and is expanding its activities here. To this end, BMs has signed an agreement to acquire the British company PolyBioMed Limited. The aim is to enhance the design, manufacturing and end-use performance of medical products with innovative materials. As a result, BMS is looking to further develop its own polyurethane-based hydrophilic coatings for medical devices with PolyBioMed's technologies. A subsidiary of Lombard Medical Technologies PLC, PolyBioMed is specialized in polymer coatings, surface treatments and biomaterials for the medical technology industry. The acquisition gives Bayer MaterialScience access to application areas such as coronary drug-eluting stents plus catheter systems for interventional cardiology, urology and neurology. 


\section{Experiencing research up close}

The new student laboratory in Leverkusen - the BayKomm Baylab - has been open since the beginning of 2010. Baylabs are designed in particular to get children and young people interested in the world of science. In the Baylab, the young visitors become researchers for a day on projects specially designed for their ages. The company's new Baylab the fourth of its kind - shows how seriously Bayer takes the support of natural science education. Bayer also provides extensive support to schools, educational establishments and the scientific community through the Bayer Science \& Education Foundation with around $€ 1$ million of funding each year. In addition, Bayer sponsors the "Jugend forscht" youth science competition and the Chemistry and Biology Olympiads.

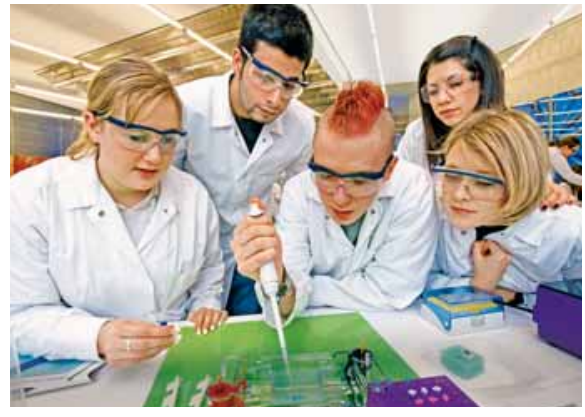

Young researchers: in the Baylabs, schoolchildren can carry out their own experiments under experienced guidance, for example to study their own DNA.

\section{Strategic step for modern plant breeding}

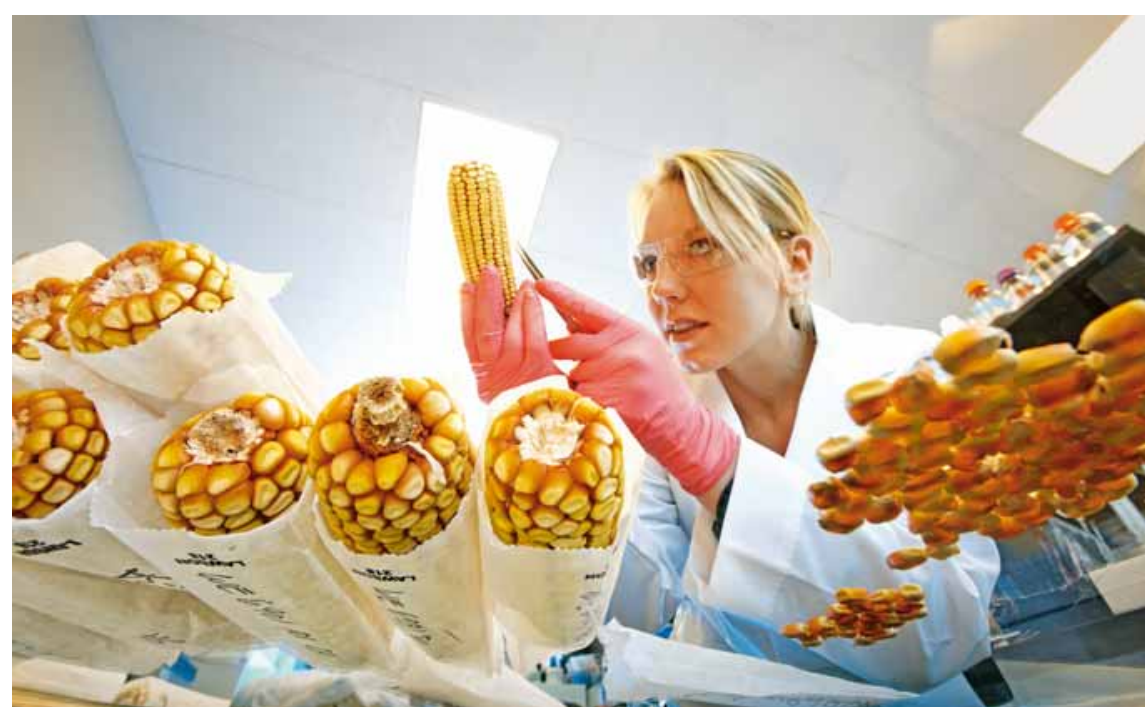

New collaboration: in the Athenix laboratory in Research Triangle Park, North Carolina, United States, Laura Schouten examines maize cobs for signs of nematodes.

In November 2009, Bayer CropScience completed the acquisition of Athenix Corp., a biotechnology company headquartered in Research Triangle Park, North Carolina, United States. Athenix not only has the largest bank of Bacillus thuringiensis $(\mathrm{Bt})$ genes in the industry, it also has an extensive herbicide toler- ance and insect resistance trait development platform. Athenix is also working on nematode (threadworm) resistance, a field in which current chemical options are limited. The company has a valuable collection of proprietary microbes that may play an important role in future trait development.

\section{Our challenges}

\section{New pipeline to safe- guard supply of CO}

Bayer MaterialScience (BMS) wants to supplement the existing integrated carbon monoxide system connection between Dormagen and Leverkusen by constructing a new co supply pipeline between the chemical facilities of Dormagen and Krefeld-Uerdingen. The aim is to ensure the safe, smooth, cross-site supply of carbon monoxide. The building work has not been completed yet. The start-up of the pipeline is dependent on various permits being obtained from the district authorities in Düsseldorf and on the outcome of legal proceedings. Some residents are worried about health risks and have filed a suit. Bayer is very much aware of its responsibility to its neighbors and the region as a whole. The safety of the pipeline takes top priority for the Group and has been attested in several expert reports. The Landtag (State Parliament) of North Rhine-Westphalia found unanimously in 2006 that the pipeline serves the common good. In the following years, too, the parliament considered the project on several occasions and has always approved it - most recently in March 2010 - with a large majority. Bayer is keen to maintain close contact with the local community and continues to provide comprehensive information about the project.

\section{Blaze at the Ankleshwar plant}

In March 2010, for as yet unknown reasons, a fire broke out at the Bayer CropScience site in Ankleshwar, India. The blaze was rapidly brought under control, but unfortunately one employee died during the incident. There was minimal impact to the rest of the site and the incident posed no hazard to the neighborhood at any time. 


\section{Positive results from study on treatment of pulmonary hypertension}

A first Phase II trial with the oral agent riociguat in pulmonary hypertension in combination with interstitial lung disease (PH-ILD) has successfully been completed. PH-ILD is a form of pulmonary hypertension for which no approved treatment options are currently available. The primary objectives of the study - to investigate the safety and tolerability of riociguat in patients - were achieved. The study demonstrated a reduction in pulmonary vascular resistance (PVR), together with a considerable increase in cardiac output and slight improvement of exercise capacity. Riociguat is the first member of a novel class of medicines known as soluble guanylate cyclase (sGC) stimulators. Bayer is investigating this active substance as a new approach to treat different forms of pulmonary hypertension. According to the wHo classification, there are five different groups of pulmonary hypertension.

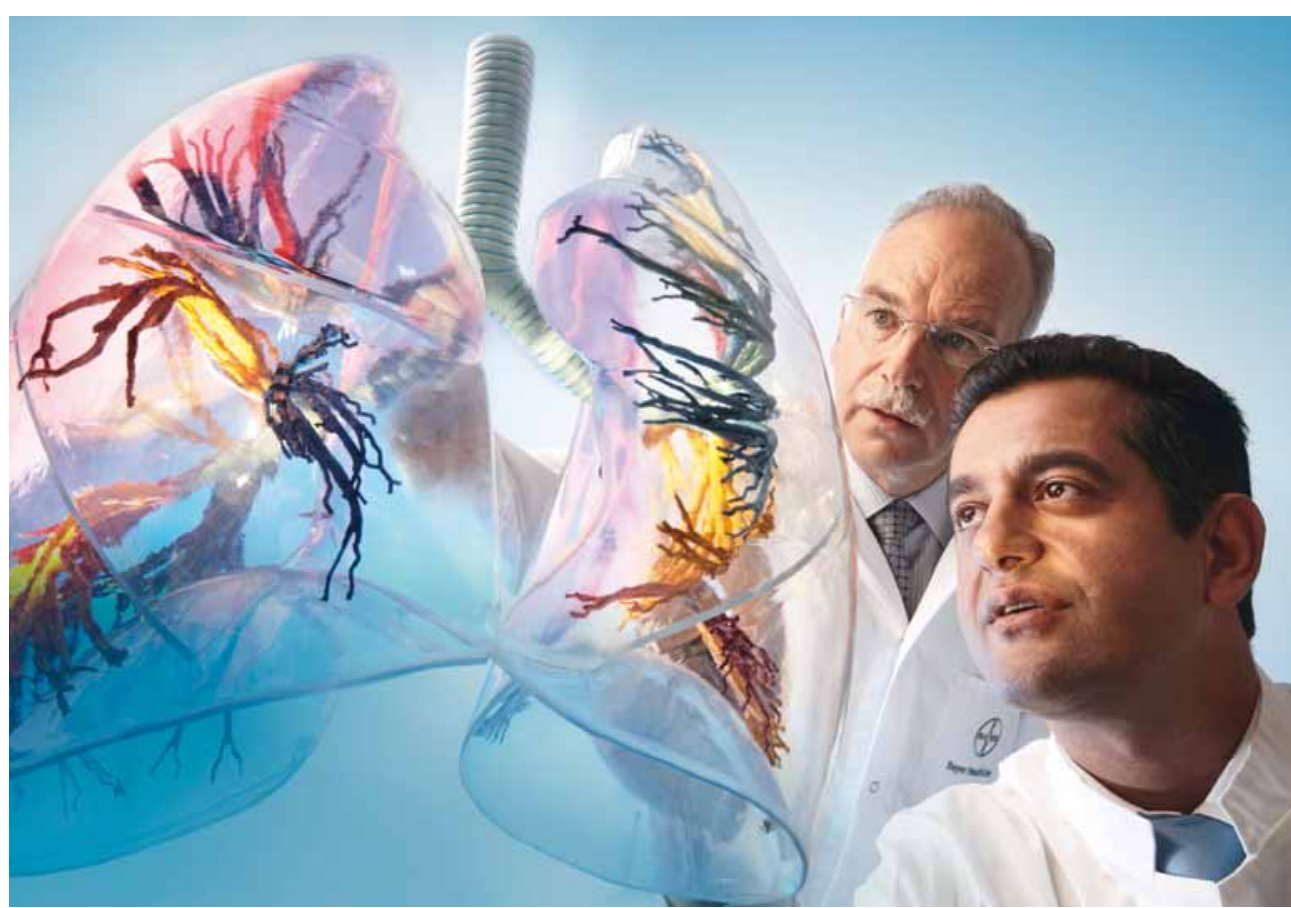

Help for pulmonary hypertension: at present there are few drugs available for the treatment of pulmonary hypertension. Bayer researcher Dr. Johannes-Peter Stasch (left) and Prof. Hossein Ardeschir Ghofrani from Giessen University Hospital, shown here with a model of a lung, have confidence in the promising new active substance riociguat.

\section{Sustainability also of major importance in the growth market of China}

Bayer is intensifying its commitment to sustainability in China, as is illustrated by the initiatives launched in 2009. In conjunction with Tongji University in Shanghai and the United Nations Environment Programme (UNEP), the Group organized the first Sustainable Development Forum. The forum, which provided the opportunity to pursue political discussions and share expertise at both a regional and international level, attracted more than 200 scientists, students and representatives from government and business. Bayer wants to support China in its efforts to follow a new course in matters of climate protection and energy efficiency. At the beginning of 2010, Bayer China was awarded the China Environmental Excellence Prize in the category "Best Corporate Performance

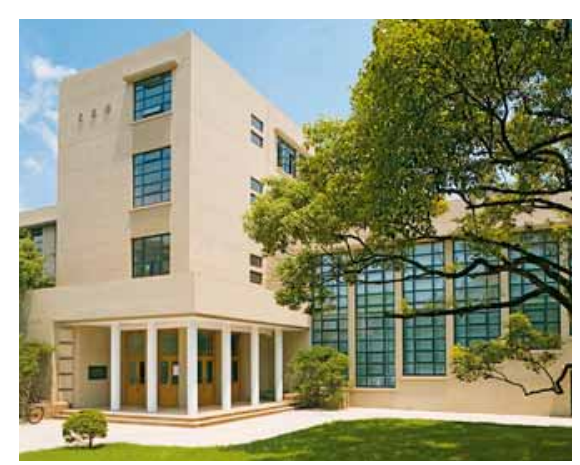

on Environmental Protection." This category, which is specifically aimed at industry, is regarded as one of the most important environmental protection awards made in the People's Republic. Before now, only two companies with headquarters outside China have won the award.

Initiative for sustainability: together with Tongji University (left) and UNEP, Bayer organized the first Sustainable Development Forum.

\section{Research cooperation in cereal cultivation}

Bayer CropScience and the Commonwealth Scientific and Industrial Research Organisation (CSIRO), Australia's national research agency, have signed a cooperation agreement to research the consequences of newgeneration cereals in the context of global environmental and food security challenges.

Innovative crops can deliver greater yields while requiring less resources such as water and energy. To evaluate the likely advantages, a methodology is to be developed to assess the effects on the environment, including the influence of the new plants on the carbon footprint of cereal production. The new project scheduled to take two years will build on the cooperation between the two organizations that began in 1998. 


\section{Our challenges}

\section{Better diagnosis of Alzheimer's disease}

In November 2009, Bayer Schering Pharma announced the start of a Phase III study to investigate the efficacy and safety of florbetaben in the identification of beta amyloid plaques in the brain using positron emission tomography (PET). The plaques are a pathological feature of Alzheimer's disease and are the focus of new therapeutic options currently under development. Florbetaben may be able to support the development of these new therapies. Bayer expects study results of relevance for a marketing authorization application to be available in 2011.

\section{Fresh hope with bone metastases}

Bayer Schering Pharma and the Norwegian company Algeta ASA will jointly develop and market the cancer drug Alpharadin ${ }^{\mathrm{TM}}$. Alpharadin ${ }^{\mathrm{TM}}$ is a new alpha-emitting radiopharmaceutical based on radium-223. The substance is currently being evaluated in a global Phase III trial for the treatment of bone metastases in prostate cancer patients who no longer respond to hormone treatment. Worldwide, prostate cancer is the second most frequently diagnosed form of cancer and one of the most common cancer-related causes of death among the male population.

\section{Greater focus on future- oriented technologies}

Bayer CropScience aims to treble its seed and biotechnology business by 2018 with investments of some $€ 3.5$ billion. The expenditures will concentrate on research and development and the infrastructure of the BioScience segment, and do not include possible acquisitions. The systematic expansion of this business goes hand in hand with the strategic alignment of Bayer CropScience, which is aimed at offering farmers integrated solutions consisting not only of products but also of technologies and services.

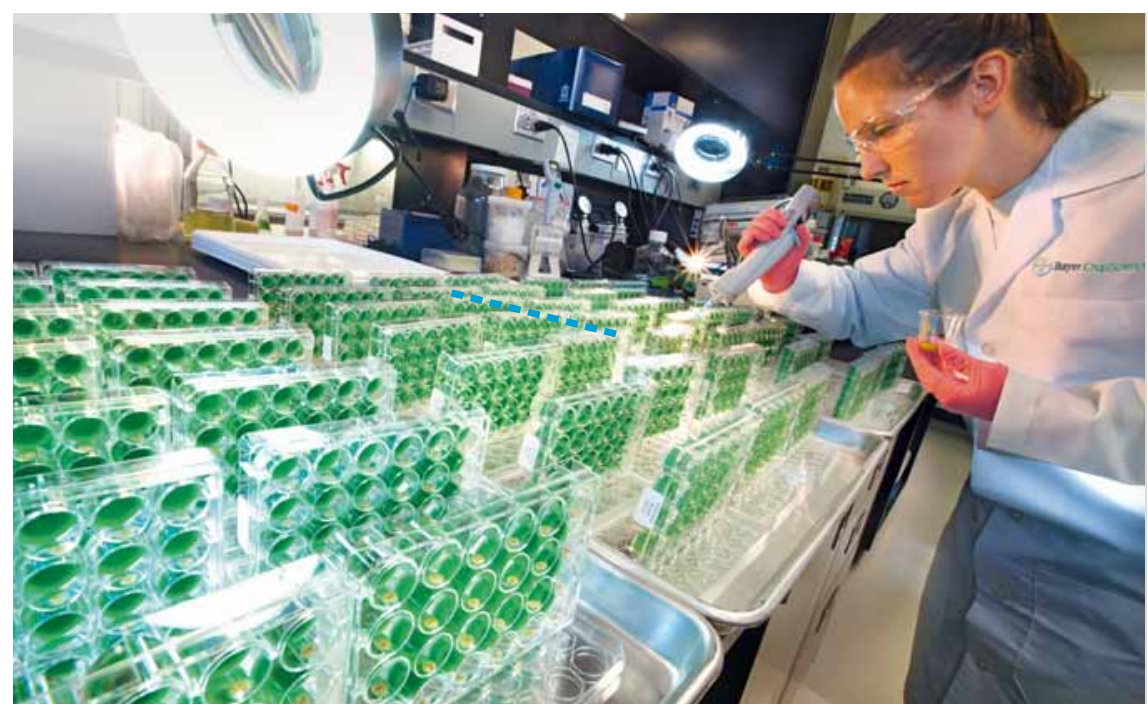

Plants of the future: Kellie Milam prepares plant trials in the lab. Here, crops are equipped with important new properties such as herbicide tolerance and resistance to insects.

\section{Combined oral contraceptives in the spotlight}

As of April 12, 2010, there were about 1,750 lawsuits pending in the United States served upon Bayer involving Bayer's oral contraceptives Yasmin ${ }^{\circledR}$ and $\mathrm{YAZ}^{\circledR}$. Plaintiffs allege to have suffered personal injuries, some of them fatal, from the use of Yasmin ${ }^{\circledR}$, $\mathrm{YAZ}^{\circledR}$ and/or Ocella ${ }^{\circledR}$, a generic version of Yasmin ${ }^{\circledR}$ marketed in the United States by Barr Laboratories, Inc. The plaintiffs seek compensatory and punitive damages, claiming in particular that Bayer knew or should have known of the alleged risks and should be held liable for having failed to disclose them or adequately warn users. Bayer believes it has meritorious defenses and intends to defend itself vigorously.

So far it appears that most of the lawsuits focus on side effects described in the product information of all combined oral contraceptives, including the Bayer products.

\section{Explosion in waste incinerator}

In September 2009, there was an explosive reaction leading to a fire in the area around a discharging unit belonging to the waste incinerator at the Supply Center in Bergkamen. It occurred while waste containing metal alkyls escaped from a transport container being emptied. The fire was extinguished. The air pollutant measurements immediately initiated gave no reasons to suspect a health risk to employees or residents. 


\title{
Moving into the future with innovations
}

\author{
Bayer is a global enterprise with core competencies in the fields of health care, nutrition and high- \\ tech materials. As an inventor company, we set trends in research-intensive areas. Our objective is to \\ offer products and services that benefit people and improve their quality of life. At the same time, we \\ aim to create value through innovation, growth and high profitability - for the benefit of our stock- \\ holders, our employees and the community in every country in which we operate.
}

Our commercial success

In 2009, Bayer was successful in a difficult environment. We achieved the third-highest earnings level in the company's history, with EBITDA before special items amounting to $€ 6.5$ billion, and came close to achieving our ambitious goal of limiting the decline in earnings against the record 2008 level to approximately 5 percent. Moreover, the net cash flow improved by 49 percent to a record $€ 5.4$ billion. Net financial debt declined further than expected, dropping $€ 4.5$ billion to $€ 9.7$ billion. Net income in 2009 was €1.4 billion.

\section{Our stock}

In 2009, Bayer stock outperformed the DAX and EURO STOXX 50 indices for the third consecutive year, gaining 34.7 percent over the year. Including the dividend of $€ 1.40$ per share paid in May 2009, the share price performance was 39.8 percent. Bayer shares ended 2009 at $€ 55.96$, very close to their high for the year. A long-term investor who purchased Bayer shares for $€ 10,000$ five years ago and reinvested all

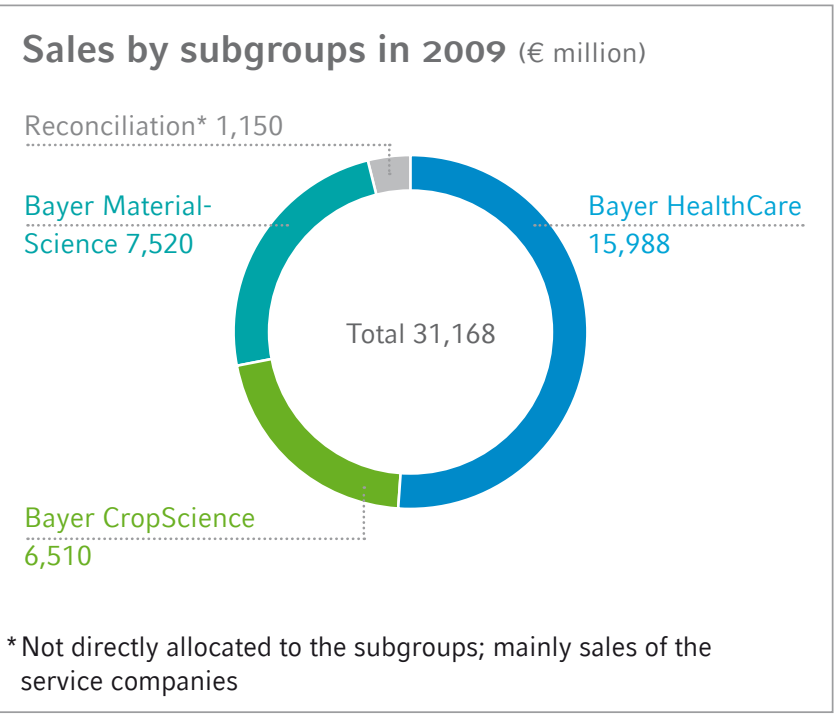

dividends would have seen the value of the position grow to $€ 27,247$ as of December 31, 2009. That corresponds to an average annual return of 22.2 percent.

Equity was €18,951 million as of December 31, 2009, including $€ 54$ million attributable to non-controlling interests. Our stockholder structure is still very international: according to a survey of shareholdings by institutional stockholders conducted in 2009, around 28.60 percent of the identified capital is held by investors based in the United States and Canada, while 25.74 percent is held by investors based in Germany. 8.48 percent of investors are based in France, Spain, Italy and Portugal, 7.10 percent in the United Kingdom and Ireland, 4.57 percent in the Benelux countries, 4.56 percent in Austria, Switzerland and Liechtenstein, and 3.11 percent in Denmark, Finland, Norway and Sweden. All other countries together account for 0.26 percent of institutional investors. The survey covered all but 17.58 percent of the capital stock.

The Board of Management and Investor Relations Department maintain a regular dialogue with private and institutional investors, for example through the Annual Stockholders' Meeting, investors' conferences, private investment forums and roadshows. Bayer also explained its commitment to sustainability at one-on-one meetings and conferences with investors.

Following the resolution adopted at the Annual Stockholders' Meeting on May 12, 2009, Bayer AG converted its entire capital stock of $826,947,808$ bearer shares into registered shares at a ratio of 1:1 in September 2009. Listing our stockholders in the share register is intended to facilitate contact with them and increase transparency.

\section{Our acquisitions and investments in 2009}

Bayer HealthCare acquired two dermatology product lines from the U.s. company SkinMedica, Inc. of Carlsbad, United States, for $€ 43$ million in 2009. Bayer CropScience acquired 
Board fulfilled its role of advising and continuously overseeing the Board of Management in 2009. Key elements of the Supervisory Board's work in 2009 were the ongoing development of corporate governance at Bayer, the amendments to the German Corporate Governance Code in June 2009 and revised legislation on the appropriateness of the compensation of members of management boards. In December 2009, the Board of Management and Supervisory Board renewed their declaration that Bayer AG had fully complied with the recommendations of the German Corporate Governance Code and would continue to do so in the future, with one temporary exception (see Annual Report 2009 on page 88).

\section{Our compensation policy}

The compensation of the Board of Management basically comprises four components: a fixed annual salary, a shortterm incentive award on a yearly basis based on a target amount, a long-term incentive award for a three-year period based on a target amount, and a company pension plan conferring pension entitlements that increase with years of service. Remuneration in kind and other benefits are also provided, such as the use of a company car for private purposes or reimbursement of the cost of health screening examinations. The short-term incentive award for 2009 is calculated partly on the Group's EBITDA margin before special items, and partly on the weighted average target attainment of the HealthCare, CropScience and MaterialScience subgroups. The target attainment of the subgroups is measured chiefly in terms of their EBITDA before special items. A qualitative appraisal in relation to the market and competitors is also taken into account.

The compensation system for the Board of Management was already aligned to sustainability and complied with the recommendations of the German Corporate Governance Code. It also met many of the demands made by the new legislation on the appropriateness of the compensation of members of management boards, which was passed in August 2009. In December 2009, the Supervisory Board resolved on adjustments to ensure that the compensation of Bayer's Board of Management continues to comply fully with the requirements of the new legislation and the recommendations of the German Corporate Governance Code. These are described in detail on page 72 .

The remuneration of the Supervisory Board is based on the relevant provisions of the Articles of Incorporation, which were last amended by a resolution of the Annual Stockholders' Meeting on April 29, 2005. This provides that, in addition to reimbursement of their expenses, each member of Bayer's Supervisory Board receives fixed and variable remuneration. The fixed annual remuneration is $€ 60,000$, while the variable component is based on corporate performance measured by the gross cash flow reported in the consolidated financial statements of the Bayer Group for the respective fiscal year. The members of the Supervisory Board receive $€ 2,000$ for every $€ 50,000,000$ or part thereof by which the gross cash flow exceeds $€ 3.1$ billion, but the total variable remuneration of each member may not exceed $€ 30,000$. In accordance with the provisions of the German Corporate Governance Code, additional remuneration is paid to the Chairman and Vice Chairman of the Supervisory Board and for chairing and membership of committees. The Chairman of the Supervisory Board receives three times the basic remuneration, while the Vice Chairman receives one-and-ahalf times the basic remuneration. Members of the Supervisory Board who are also members of a committee receive an additional one quarter of the amount, with those chairing a committee receiving a further quarter. However, no member of the Supervisory Board may receive total remuneration exceeding three times the basic remuneration. It has been agreed that no additional remuneration shall be paid for membership of the Nominations Committee. If changes are made to the Supervisory Board and its committees during the fiscal year, members receive remuneration on a pro-rated basis. Details of remuneration received by individual members of the Board of Management and Supervisory Board are disclosed in our Annual Report.

\section{Sustainability criteria as a performance yardstick}

We have started to link the variable remuneration of Bayer executives directly to success in the sustainability arena by including sustainability criteria in their annual personal performance objectives. Our aim is to ensure a close link between sustainability targets and variable compensation components throughout the Group.

\section{Our global workforce}

Bayer's success is based on the day-to-day commitment of our 108,400 employees around the world (2008: 108,600). Around 34 percent (2008: 34 percent) of them work at our sites in Germany. Globally, around 72 percent of our employees (2008: 74 percent) are in countries that belong to the Organisation for Economic Co-operation and Development (OECD). Almost 28 percent (2008: 26 percent) work in a total of 43 non-OECD countries. The largest of these is China, where we have around 7,435 employees, followed by India $(3,688)$ and Brazil $(3,370)$. 


\section{The Bayer Group}

The Bayer Group is a global enterprise with companies all over the world.

The map shows some of our most important locations.

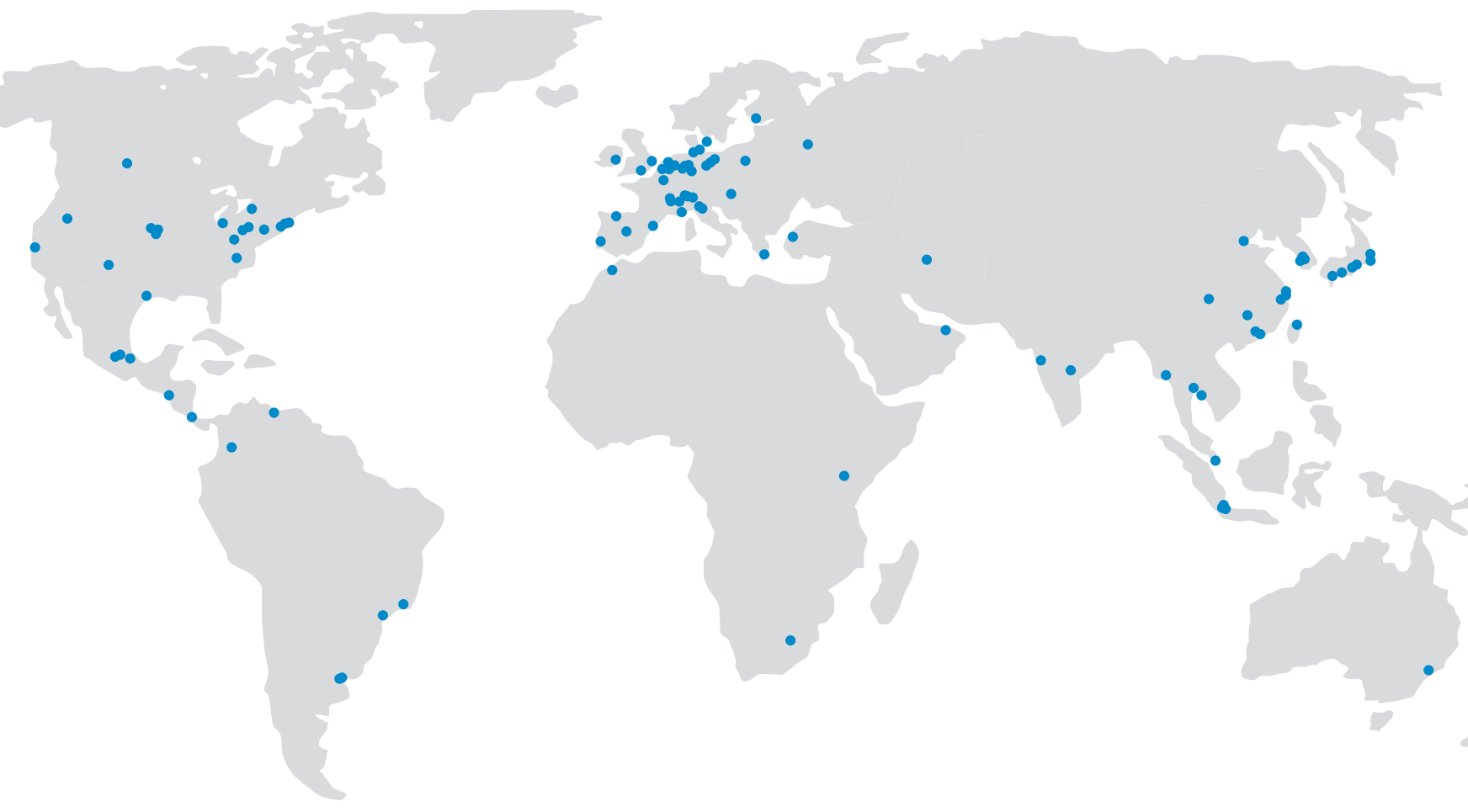

The Bayer Group in 2009 in figures (values for previous year in brackets)

\begin{tabular}{l|c|c|c|c|c} 
& $\begin{array}{c}\text { North } \\
\text { America }\end{array}$ & $\begin{array}{c}\text { Latin America/ } \\
\text { Africa/ } \\
\text { Middle East }\end{array}$ & Europe & Asia/Pacific & Total \\
\hline Sales (€ million) & $7,705(8,026)$ & $4,783(4,958)$ & $12,968(14,549)$ & $5,712(5,385)$ & $31,168(32,918)$ \\
\hline Employees & $16,300(17,000)$ & $16,000(15,300)$ & $54,500(55,500)$ & $21,600(20,800)$ & $108,400(108,600)$ \\
\hline $\begin{array}{l}\text { R+D expenditures } \\
(€ \text { million) }\end{array}$ & $507(459)$ & $28(36)$ & $2,080(2,014)$ & $131(144)$ & $2,746(2,653)$ \\
\hline $\begin{array}{l}\text { No. of fully consolidated } \\
\text { companies }\end{array}$ & $44(45)$ & $45(46)$ & $156(167)$ & $57(58)$ & $302(316)$
\end{tabular}

WWW 1 Annual Report | 2 Investor relations | 3 Stock market indices which include Bayer | 4 Supervisory Board $\mathbf{5}$ Corporate governance | 6 Board of Management I 7 Compensation I 8 Bayer sites 


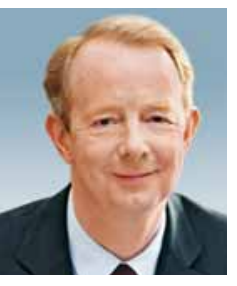

Dr. Marijn Dekkers,

Chairman of the Executive Committee (until August $14,2010)^{*}$ of

Bayer HealthCare

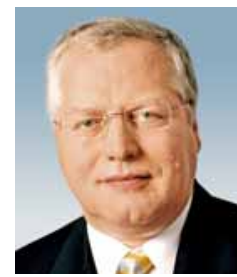

Professor

Friedrich Berschauer, Chairman of the Board of Management (until September 30, 2010)* of Bayer CropScience AG

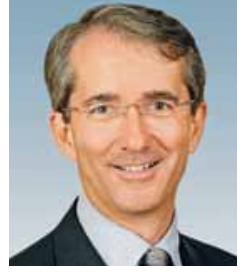

Patrick Thomas, Chairman of the Board of Management of Bayer MaterialScience AG

\section{Strong partnerships for global health care}

As a health care company, our role is to develop innovative medicines and medical equipment and bring these products to market. This task is closely linked to our commitment to achieving improved access to health care and medical care worldwide. Our business objectives require us to live up to our social responsibility.

To this end we invest continuously in the development and optimization of products which benefit people and society worldwide and improve the quality of life. Our research and development activities focus on serious and chronic diseases.

We are also involved in public-private partnerships with non-governmental organizations, government organizations and other companies committed to the global improvement of health care provision. Our main focus is on global family planning programs, the control of neglected diseases, and access to innovative medicines.

We are also committed to breaking down barriers which block access to innovative medicines by people in developing countries. Our business conduct is at all times governed by our responsibility to people, animals and the environment.

\section{Innovations to meet the global demand for food}

Agriculture is facing some major challenges. The world's population is growing relentlessly. At the same time, the growing demand for food is colliding with the restraints imposed by limited arable land and harvests at the mercy of climate change. The productivity of plants must be improved in order to ensure a sustainable supply of food worldwide.

As one of the leading companies in crop protection, seeds and plant traits, we believe that we have an obligation to work towards this goal. Every day, our technological expertise, our business skills and, not least, our products make an important contribution to achieving sustainable development. Research and development activities pursued on our own and with cooperation partners enable us to develop solutions which can safeguard and boost yields.

Sustainable agriculture can only be achieved on the basis of functioning ecosystems. The preservation of biodiversity is therefore one of our deeply rooted objectives. In many regions, particularly in Latin America and Asia, we also contribute to social and economic development by supporting local agriculture. The Food Chain Partnerships project organized by Bayer CropScience, for example, helps fruit and vegetable farmers to grow and market their produce.

\section{High-tech materials for increased energy efficiency}

Our innovative materials offer efficient solutions to effectively counteract the increase in global energy consumption. The ecological focus of our sustainable development strategy is just one aspect. Sustainability is also firmly anchored in the safety, financial performance, product development and process engineering segments of our business. The success of our company is based primarily on our people. Their happiness, protection and safety are the top priorities for us. We take our responsibility to society and to all our stakeholders very seriously. To ensure the company's sustainability, we need to deliver an impressive financial performance, and this is another cornerstone of our sustainability strategy.

We intend to play a leading role in reducing the environmental impact of our industry. Our particular focus is on reducing energy consumption and carbon dioxide emissions through innovative products and new, future-oriented applications in process engineering and development. These are projects that will benefit people both today and in the future.

We provide innovative materials for zero-emission houses as part of the EcoCommercial Building Program. This program shows how we are actively putting climate protection into practice.
Headquarters: Leverkusen, Germany

Headcount: 53,400 (2009) 53,100 (2008) Sales: €16.0 billion (2009),

$€ 15.4$ billion (2008)

Sites: in over 120 countries

Specific directives: Voluntary

commitment to Responsible Care, 2003;

Sustainable Development Strategy, 2009; CMS (Compliance Management System)

Basic Policy Statements, 2009

Website: www.bayerhealthcare.com
Headquarters: Monheim, Germany

Headcount: 18,700 (2009), 18,300 (2008)

Sales: €6.5 billion (2009),

$€ 6.4$ billion (2008)

Sites: in over 120 countries

Specific directives: Voluntary

commitment to quality, health, safety and environmental protection (QHSE), 2009;

Product Stewardship Policy 2009

Website: www.bayercropscience.com
Headquarters: Leverkusen, Germany

Headcount: 14,300 (2009), 15,100 (2008)

Sales: €7.5 billion (2009),

$€ 9.7$ billion (2008)

Sites: in over 55 countries

Specific directives: Voluntary

commitment to health, safety, environment and quality, revised

version 2008

Website: www.bayermaterialscience.com 
Bayer Business Services

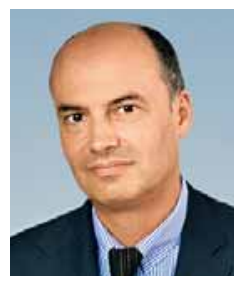

Daniel Hartert,

Chairman of the

Executive Board

of Bayer Business

Services $\mathrm{GmbH}$
Bayer Technology Services

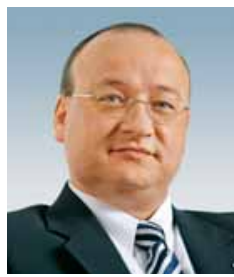

Dr. Dirk Van Meirvenne, Managing Director (effective June 1, 2010)* of Bayer Technology Services $\mathrm{GmbH}$

\section{Currenta}

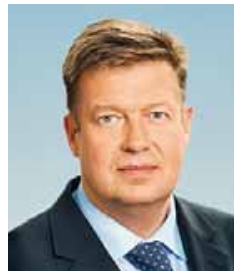

Dr. Klaus Schäfer, Chairman of the Executive Board of Currenta $\mathrm{GmbH}$ \& $\mathrm{Co}$. $\mathrm{OHG}$

\section{Services for a sustainable future}

Bayer Business Services is the Bayer Group's international competence center for IT and business services. We focus on offering services in the core areas of IT infrastructure and applications, procurement and logistics, human resources and management services, and finance and accounting. Our innovative solutions make business processes faster, simpler and more cost-efficient. In this way we make an important contribution to sustainable development at Bayer.

We are working on three initiatives - EcoFleet, Business Travel and Green IT - as part of the Bayer Climate Program. Under the EcoFleet initiative, we are looking to cut the $\mathrm{CO}_{2}$ emissions of Bayer company vehicles by 20 percent between 2007 and 2012. Through the introduction of innovative high-definition video conferencing systems, the Business Travel initiative is providing carbon-dioxide-cutting alternatives to business trips. And through Green IT we aim to reduce the energy consumption of our three data centers by 20 percent between 2009 and 2012.

By introducing a new screen saver, which we installed in 2009 on all 85,000 PC and laptop workstations around the world supported by Bayer Business Services, and by changing PCs and laptops over to energy-saving settings we shall enable up to three million kilowatt hours of energy to be saved every year. That corresponds to a reduction of up to 1,700 metric tons of carbon dioxide.

\section{Innovative environmental protection worldwide}

Bayer Technology Services is the Bayer Group's global technological backbone and a key innovation driver for the development, planning, construction and optimization of processes and plants.

Bayer Technology Services is involved in ensuring that Group-wide ecological and social responsibilities are met globally. This includes implementing international standards at all sites, as well as developing processes and planning and constructing plants in line with the latest technology.

We have, for example, developed the Bayer Climate Check, which provides detailed statistical data on all emissions caused by individual production processes. This instrument enables the prioritization of measures aimed at maximizing the potential for reducing emissions, and was successfully introduced at more than 100 production plants in 2009 as part of the Bayer Climate Program. On the basis of the good results achieved to date, a further 40 Bayer plants will be analyzed using this method by mid-2010, and the technology will also be offered to external companies.

Another example is BayOpX ${ }^{\circledR}$, the Bayer Technology Services Operational Excellence Program, which is designed to identify further optimization potential, for example in raw materials consumption or plant availability.

\section{Energy-efficient chemical park operator}

Currenta offers services for the chemical industry, including utility supply, waste management, infrastructure, safety and security, analytics and vocational training. This service company - a joint venture between Bayer and Lanxess - operates the CHEMPARK sites in Leverkusen, Dormagen and KrefeldUerdingen, Germany.

As the manager of CHEMPARK, we offer attractive conditions for production, thereby maintaining the competitiveness of our sites. We focus on rigorously optimizing technologies and processes and on the implementation of our climate protection program A++, with the aim of increasing the energy and commercial efficiency of our facilities and at the same time conserving natural resources. Occupational safety has a top priority at Currenta, which is why we launched our "Working together to improve safety" initiative in 2009. Through this we are endeavoring to further reduce the injury figures and establish a sustainable safety culture in the company. Another key area of our commitment is staff development and training. Our focus here is on our company health management system, age-appropriate workplace ergonomics, strengthening the leadership culture in the company, broadening staff qualification as part of a lifelong learning process and a future-oriented recruitment policy.
Headquarters: Leverkusen, Germany

Headcount: 5,600 (2009), 5,500 (2008)

Sites: in over 70 countries

Specific directives: Voluntary

commitment to Responsible Care by

Bayer Business Services, 2003

Website: www.bayerbbs.com
Headquarters: Leverkusen, Germany

Headcount: 2,600 (2009), 2,600 (2008) Sites: Belgium, Germany, India,

Mexico, P.R. China, Switzerland, Singapore, United States, United Arab Emirates

Specific directives: Health, safety, environment and quality policy in BTS

Website: www.bayertechnology.com
Headquarters: Leverkusen, Germany Headcount: 5,400 (2009), 5,500 (2008) (both figures excluding trainees)

Sites: Leverkusen, Dormagen, KrefeldUerdingen (all Germany)

Specific directives: Voluntary commitment to Responsible Care of Bayer Industry Services, 2003; Policy on health protection, safety, environmental protection and quality, 2004 Website: www.currenta.com 


\title{
Our sustainability management
}

\author{
The world is facing a number of major challenges - among the greatest of these is global population \\ growth and the associated exacerbation of other important factors: sufficient food, access to health \\ care, and environmental and climate protection. These global issues are at the focus of our revised \\ sustainability strategy.
}

For Bayer, a corporate management strategy oriented to values and sustainability is the key to lasting success. Our business and sustainability strategies help us to manage the company responsibly and strengthen its competitiveness over the long term. Sustainable development forms an integral part of our corporate policy, which is geared toward long-term success and high-quality solutions. Our vision is to achieve sustainability in everything we do.

\section{In line with external trends and expectations}

Bayer views itself as a member of society - both globally and locally in all the regions and countries in which we operate. Companies such as Bayer can play a decisive role in assuming responsibility and developing solutions. Responsible actions of companies are scrutinized and their license to operate debated. All stakeholder groups - be they analysts, investors, employees, customers, politicians or regulatory authorities - increasingly expect sustainability concepts and performance. We focus on balancing commercial success based on sound business models with the needs of our employees and of society at large. This means that we take external trends and expectations into account in our strategies and activities. This also necessitates a high level of transparency, which increasingly demands the recording of non-financial, quantitative indicators.

\section{Development of sustainability}

Responsible Care has long been a central objective of our business policy. This was reflected in our program "Bayer: research for a clean environment" in the 1970s and 1980s, and is now expressed in our commitment to the Responsible Care initiative and in the agreements we reached with the workforce to safeguard employment. We published our first Environment and Social Report in 1976 and our first international Environmental Protection Report in 1992. In 2000, we were among the founding members of the UN Global Compact.

This basic understanding is also integral to our company values and principles, which include the sustainability of our actions, respect for people and nature, and a passion for our employees, business partners, stockholders and society at large. Other values anchored in our mission statement "Bayer: Science For A Better Life" are a will to succeed and integrity, openness and honesty.

\section{The Bayer sustainability concept}

Successful sustainable development in balance with social needs and goals

1. The basis of our strategy comprises our products and innovations, which create value for our business and society.

2. Our everyday business practices in dealings with our suppliers, employees and customers are aligned to sustainability. Core areas include compliance, product stewardship, a responsible human resources policy and sustainable supplier management.

3. In addition, with our foundations and voluntary social activities we assume targeted corporate social responsibility. The focus is on issues of particular social relevance with a clear link to Bayer.

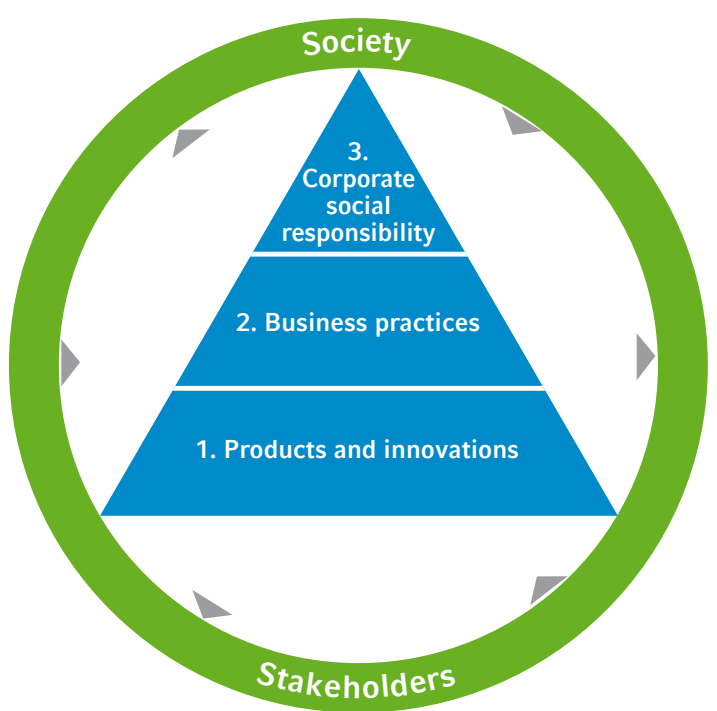


Objectives of our sustainability strategy - sustainability is business-oriented

Sustainability at its core means the ability to thrive in the future. It is an elementary component of our business strategy. On the one hand, sustainability trends open up new market opportunities that support our competitiveness and safeguard earnings in the long term. On the other hand, we want our business activities to benefit customers and society at large - economically, ecologically and socially. Innovation plays a dual role in this context:

- creating new solutions to master global challenges

- integrating sustainability requirements into innovation management

Despite the economic crisis, therefore, Bayer has further increased its research and development budget.
In addition to this business focus, we are also active in social areas that are of strategic importance to us. This commitment includes a number of projects from our Climate Program (such as the Bayer Climate Award), our efforts to tackle neglected diseases such as Chagas disease, and our partnership for youth and environment with UNEP.

\section{Portfolio and business strategies}

Major global trends have a very significant impact on our company in terms of safeguarding our future viability. Such trends include global population growth, rising life expectancy, climate change and water scarcity. These trends are creating challenges that we must address and overcome. We therefore integrate them into our strategies. We also include in our deliberations issues covered by the United Nations Millennium Development Goals such as poverty, nutrition and health care. At the same time, these challenges pro-

\section{Further development of our sustainability strategy}

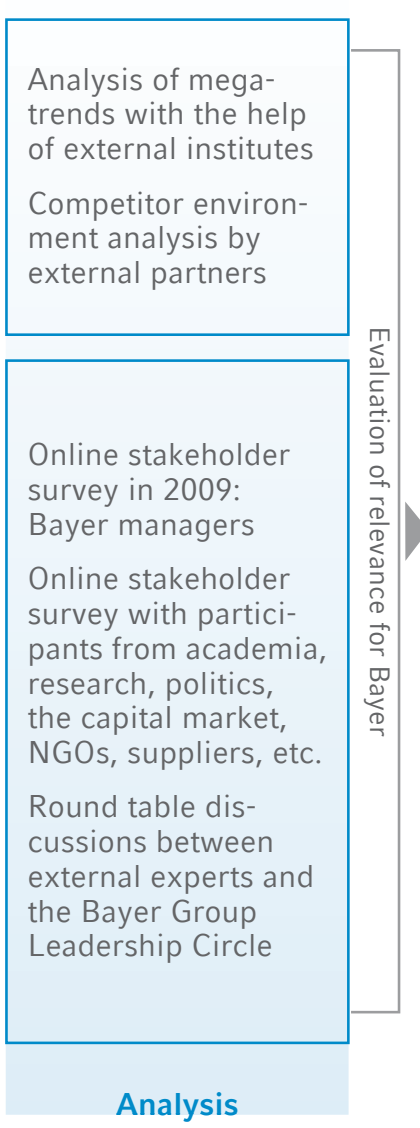

Materiality analysis used for the Sustainability Program: trends and challenges were analyzed with respect to their relevance for Bayer with the aid of internal and external tools, and above all through the involvement of stakeholders. The further development of our sustainability strategy is based on this. It was adopted by the Community Board for Sustainable Development and the Group Management Board. The Sustainability Program currently comprises eight so-called lighthouse projects that illustrate the focus of our strategy particularly clearly.

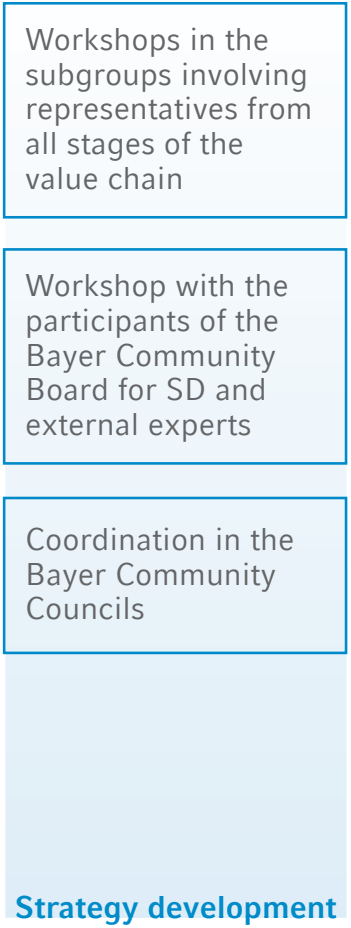

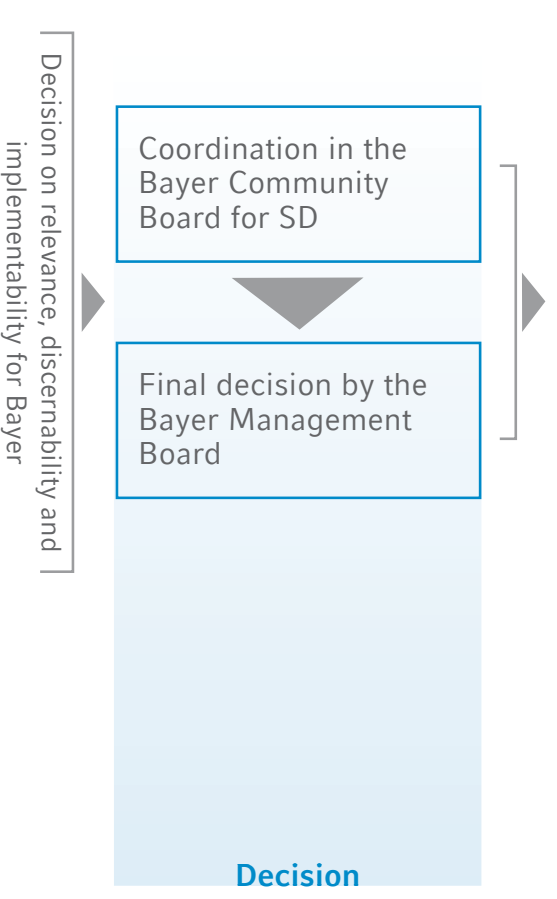

Final decision by the Bayer Management Board
Bayer Program Sustainability

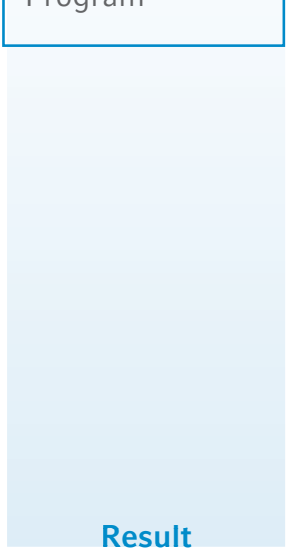


vide us with business opportunities. To systematically take account of trends - as well as internal and external factors - we have incorporated a materiality analysis system into our strategy process (see chart on page 19).

\section{Sustainability Program}

In accordance with this further development of our sustainability strategy, we have drawn up a Sustainability Program. This program currently comprises eight so-called lighthouse projects that illustrate the focus of our strategy particularly clearly.

1. Global access to health care: Bayer HealthCare's goal is to develop innovative pharmaceuticals, diagnostic options and medical equipment that benefit patients worldwide and improve their quality of life. We contribute these solutions to alliances to help provide health care worldwide (see also Focus Issue Health on page 30).

2. Nutrition for a growing world population: as an innovation leader, Bayer CropScience provides farmers with modern crop protection options and new solutions based on plant breeding and biotechnology to safeguard and increase harvest yields. We contribute this expertise to partnerships involving all players in the value chain that are aimed at achieving greater amounts of high-quality food (see also Focus Issue Nutrition on page 36 ).
3. Solutions for climate protection and resource use: Bayer MaterialScience develops innovative materials and processes to increase energy efficiency. This includes the company's own production activities, as well as products for sustainable buildings, lighter-weight cars and efficient wind turbines (see also Focus Issue Climate Protection on page 42).

\section{Organization and steering}

The Bayer Community Board for Sustainable Development (CB SD) is responsible for steering our sustainability strategy across the Bayer Group. Headed by the member of the Board of Management responsible for Innovation, Technology and Environment, this body each year defines goals, adopts corresponding Group directives and monitors the implementation of the measures involved. Further members include one management board member from each of the subgroups, the managing directors/executive board chairmen of the Bayer service companies, and the heads of six Corporate Development departments.

The CB SD is supported by a further sustainability body, the Bayer Community Council for Sustainable Development (CC SD). Here, the sustainability officers from the subgroups and service companies steer the implementation of our strategy under the leadership of the Head of Environment \& Sus-

\section{Bayer Sustainability Program}

\begin{tabular}{|c|c|c|c|}
\hline Challenge & $\begin{array}{l}\text { Global access to } \\
\text { health care }\end{array}$ & $\begin{array}{l}\text { Nutrition for a growing } \\
\text { population }\end{array}$ & $\begin{array}{l}\text { Climate and environ- } \\
\text { mental protection }\end{array}$ \\
\hline Focus & $\begin{array}{l}\text { Health care alliances } \\
\text { for SD }\end{array}$ & More quality food & $\begin{array}{l}\text { Solutions for } \\
\text { climate protection } \\
\text { and resource use }\end{array}$ \\
\hline $\begin{array}{l}\text { Lighthouse } \\
\text { projects }\end{array}$ & $\begin{array}{l}\text { Family planning } \\
\text { Neglected diseases }\end{array}$ & $\begin{array}{l}\text { Food Chain } \\
\text { Partnership for } \\
\text { vegetables } \\
\text { Direct seeding of } \\
\text { rice }\end{array}$ & $\begin{array}{l}\text { EcoCommercial } \\
\text { Building program } \\
\text { Energy efficiency } \\
\text { Resource efficiency }\end{array}$ \\
\hline
\end{tabular}


tainability. This necessitates close coordination with further Bayer Group bodies such as the Bayer Community Council for Health, Safety, Environment \& Quality (CC HSEQ), the Bayer Community Council for Innovation, the Bayer Community
Council for Industrial Operations and the Bayer Community Council for Politics. The global organization is rounded off by committees at subgroup and regional level. Group-wide cooperation is governed by our Sustainable Development Policy.

\section{Bayer Community Board for Sustainable Development (CB SD)}

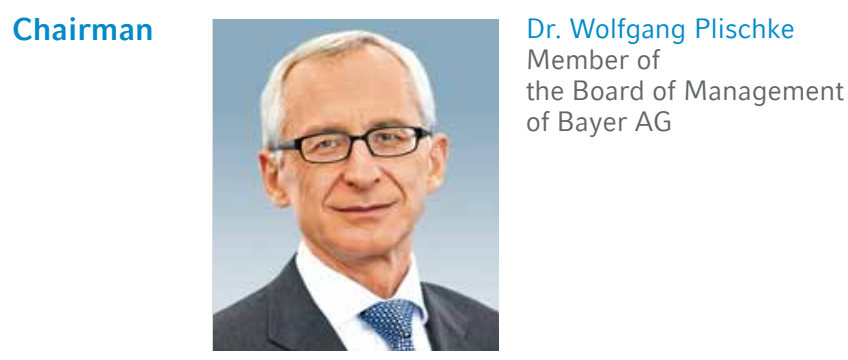

\section{Members}

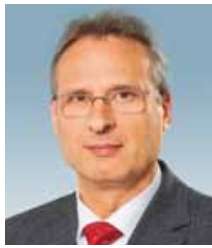

Dr. Hartmut Klusik Bayer HealthCare, Head of Product Supply

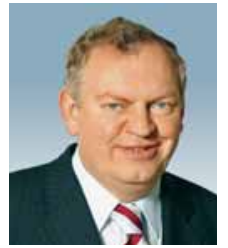

Dr. Franz-Josef Placke Bayer CropScience, Head of Development

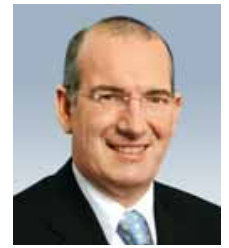

Dr. Tony Van Osselaer Bayer MaterialScience, Head of Industrial Operations

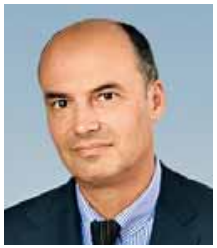

Dr. Daniel Hartert

Bayer Business Services, Chairman of the Executive Board

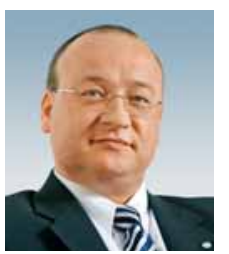

Dr. Dirk Van Meirvenne* Bayer Technology Services, Managing Director

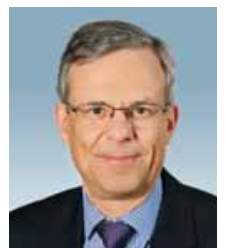

Jörg Krell Bayer AG,

Head of the Corporate Office

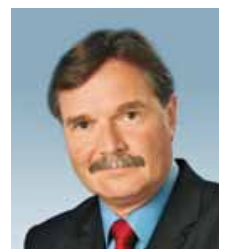

Michael Schade Bayer AG,

Head of Communications

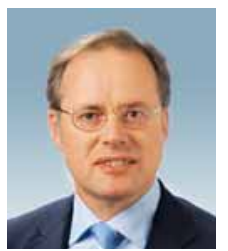

Dr. Alexander Rosar Bayer AG,

Head of Investor Relations

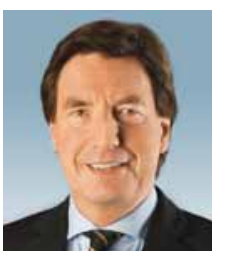

Jan Peters

Bayer AG,

Head of Corporate Human Resources \& Organization

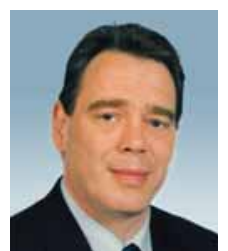

Dr. Matthias Mangold Bayer AG,

Head of Corporate Development

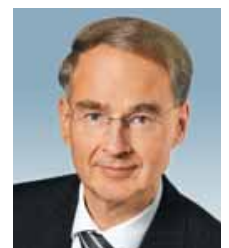

Dr. Roland Hartwig Bayer AG,

Head of Law \& Patents, Insurance

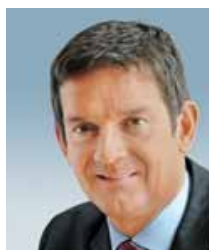

Dr. Wolfgang Grosse Entrup Bayer AG,

Head of Environment \&

Sustainability 
Integration of sustainability at Bayer

Our commitment to uphold the 10 principles of the UN Global Compact and the Responsible Care initiative of the chemical industry underlines our adherence to sustainability. These internationally acknowledged sustainability principles and our mission statement "Bayer: Science For A Better Life" give all organizational units and employees a clear orientation framework. The principle of sustainability is therefore also enshrined in our internal Group regulations such as the Bayer Sustainable Development Policy, our position on human rights and labor conditions and our Corporate Compliance Policy.

On this basis we develop Group-wide directives covering issues such as HSEQ audits, donations and process and plant safety designed to ensure that our sustainability strategy is consistently implemented in all parts of the company and along the entire value chain.

The implementation of the directives is definitively supported by efficient management systems in all subgroups and service companies:

- HSEQ (health, safety, environment and quality)

To ensure uniformly high health, safety, environment and quality standards, Bayer has established HSEQ management systems that are aligned to acknowledged international standards (see Performance Report on page 51f.). In addition, the subgroups enact systems and rules that address their productspecific requirements.

By continuously updating and expanding HSEQ directives and through internal audits, each organizational unit ensures that its management systems meet the current requirements. The Bayer Group also regularly conducts internal observer audits of the subgroup audit processes.

\section{- Compliance}

We continuously develop our Corporate Compliance Program further and support its implementation with various internal Group initiatives. To anchor the theme of compliance more strongly in the leadership organization, we have made it a target attainment criterion in the annual performance appraisal of Group Leadership Circle (GLC) members. As such, it is relevant to the variable compensation component of each GLC member (see Performance Report on page 59f.).

\section{- Sustainable procurement management}

The policy guideline of the Group-wide Procurement Community also clearly supports the principles of the UN Global Compact, our values and leadership principles, and Bayer's position on human rights and labor conditions.

\begin{tabular}{|c|c|c|c|c|c|}
\hline \multirow{6}{*}{ 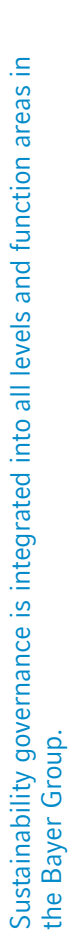 } & \multicolumn{5}{|c|}{ Integration of sustainability at Bayer } \\
\hline & \multirow{2}{*}{$\begin{array}{l}\text { Group level: } \\
\text { General }\end{array}$} & \multicolumn{4}{|c|}{ Bayer mission statement: "Science For A Better Life" } \\
\hline & & \multicolumn{4}{|c|}{ Values and leadership principles } \\
\hline & & \multicolumn{4}{|c|}{ Sustainability strategy } \\
\hline & $\begin{array}{l}\text { Group level: } \\
\text { Sustainability }\end{array}$ & $\begin{array}{l}\text { Commitments } \\
\square \text { UN Global Compact } \\
\square \text { Responsible Care } \\
\square \text { World Business } \\
\text { Council for Sustain- } \\
\text { able Development } \\
\square \text { Corporate citizen- } \\
\text { ship }\end{array}$ & $\begin{array}{l}\text { Relevant positions } \\
\text { such as } \\
\square \text { Sustainable } \\
\text { Development } \\
\square \text { Human Rights } \\
\square \text { Corporate } \\
\text { Compliance } \\
\square \text { Responsible } \\
\text { Lobbying }\end{array}$ & $\begin{array}{l}\text { Committees such as } \\
\square \text { Community Board } \\
\text { for SD } \\
\square \text { Community Council } \\
\text { for SD } \\
\square \text { Community Council } \\
\text { for HSEQ } \\
\square \text { Community Council } \\
\text { for Politics }\end{array}$ & $\begin{array}{l}\text { Sustainability } \\
\text { performance } \\
\square \text { Sustainability } \\
\text { Program } \\
\square \text { Targets/KPIs } \\
\square \text { Reporting }\end{array}$ \\
\hline & $\begin{array}{l}\text { Subgroup and } \\
\text { service company } \\
\text { level (including } \\
\text { regions and coun- } \\
\text { tries) }\end{array}$ & \multicolumn{4}{|c|}{$\begin{array}{l}\text { Policies, objectives and strategies, HSEQ management systems and audits, } \\
\text { Responsible Care programs and initiatives, opportunity and risk management }\end{array}$} \\
\hline
\end{tabular}


Bayer has combined all of its fundamental sustainability standards and requirements for its suppliers in a Supplier Code of Conduct ( $\mathrm{SCoC}$ ). The code is accessible on the Internet and published as a brochure in seven languages, and has been implemented on a step-by-step basis since December 2009. Implementation of the code is steered by the Procurement organization.

The code of conduct comprises the areas of ethics, employee relations, management systems, and health, safety, environment and quality (HSEQ). It covers, for example, the prohibition of corruption and child labor, the observation of human rights, the assurance of product and workplace safety and health protection, and the responsible use of natural resources.

Prior to the publication of the code, strategic purchasers around the Group were acquainted with its contents and with the supplier selection and evaluation procedure in a web-based training course based on specific examples. So far, more than 1,100 employees from 37 countries - or nearly 100 percent of the relevant purchaser group - have participated in the training course, which consists of three modules.

Our procedure for selecting and evaluating suppliers specifies in detail the four-step method for implementing the code of conduct. In the first step, our purchasers notify suppliers of the new code. After that, the risks existing in the supplier country are determined using a special Bayer Country Sustainability Risk Index. The third step is the assessment of performance: our purchasers evaluate the individual suppliers' specific sustainability achievements and risks using a questionnaire.

By the end of 2009, 116 suppliers had been evaluated according to this new procedure in a globally coordinated manner. In 2010, we plan to assess more than 150 further suppliers. Additional suppliers are evaluated through country- and subgroup-specific projects.

The fourth step involves the use of the results of the questionnaire to determine whether respective suppliers meet Bayer's requirements or whether it is necessary to work with them to develop them further and establish goals. Bayer undertakes to maintain close and productive cooperation with its suppliers. However, if all efforts to develop a certain supplier fail and the plan of action cannot be implemented within the agreed timeframe, a termination of the contractual relationship is considered. In addition, our Quick Check Tool for New Suppliers - a first-time evaluation of new suppliers - is available for those who have not yet worked together with Bayer.
To introduce the supplier code, information events and workshops have already been held for our suppliers in Germany and Spain and at sites in China and India.

\section{- Risk management}

The steering of opportunities and risks is an integral part of the Group-wide management system (see page 62f.). In addition, the subgroups enact systems and standards that address their specific requirements.

\section{The Bayer Sustainability Check}

We want our products to satisfy economic, ecological and social criteria. We therefore worked together with z_punkt, a renowned trend research institute, to design and develop a tool with which individual products and product groups are analyzed in detail with respect to sustainability aspects: the Bayer Sustainability Check (formerly Sustainability Value Balance). The methods of the tool were certified by the internationally recognized Wuppertal Institute of Climate, Environment and Energy.

The tool enables Bayer to systematically evaluate its product portfolio and align it to societal megatrends such as population growth or climate change. The Bayer Sustainability Check compares the positive contributions our products make to sustainability effects during their development, manufacture, marketing, use and disposal with potential negative effects.

In 2009, we successfully used three pilot projects to test applicability in all three subgroups. For example, Bayer MaterialScience analyzed polyurethane insulation panels. The main sustainability effect here comes from energy savings achieved during their use. The check shows that our products also favorably impact other socio-economic sustainability parameters. There were equally surprising positive results when we analyzed an innovative cereal herbicide at Bayer CropScience. The deployment of our herbicide enables a productivity gain in the region of one million metric tons of additional cereal.

We plan to roll out the tool this year. To this end, we will use the Sustainability Check to evaluate six further products or product groups. Through increased transparency and elevated awareness, we want to further raise the contribution to sustainability of our products and processes with the aid of the check.

\section{Objectives}

Sustainable development objectives are an integral part of our management process. With our 2006+ program of objectives, we have set ourselves ambitious goals in the areas of innovation, product stewardship, excellence in corporate management, social responsibility and responsibility for the environment. The 
program was expanded at the end of 2007 to include the Bayer Climate Program goals.

This program of objectives comprises all sustainabilityrelevant goals and measures throughout the Bayer Group, the subgroups and the service companies through the end of 2010. The implementation of these measures is regularly monitored by the management and executive boards of the individual subgroups and service companies, and by our SD committees. The table shows the 10 most important targets from this extensive catalogue; the status of all these targets can be found on the Internet.

A progress report on our program of objectives 2006+ will be contained in our Sustainable Development Report 2010. We will also set and publish new, focused Bayer Group objectives. In this connection, we aim to define measurement parameters that quantify if possible not just our input, but also the output and effects of our activities. After all, we are convinced that measurability and transparency are becoming increasingly important.

\section{Key sustainability targets of the Bayer Group through 2010} (unless stated otherwise):

\begin{tabular}{|c|c|}
\hline & $\begin{array}{c}\text { Target achievement } \\
\text { by } 2009\end{array}$ \\
\hline $\begin{array}{l}\text { Cancer therapy } \\
\text { Expansion of the scope of application for the cancer drug Nexavar }{ }^{\circledast} \text { to include the indications liver, } \\
\text { lung and breast cancer }\end{array}$ & \\
\hline $\begin{array}{l}\text { Therapeutic proteins } \\
\text { Development of patient-specific medicines by } 2015 \text { through the expression of therapeutic proteins } \\
\text { from tobacco plants (plant-made pharmaceuticals), see also page } 56\end{array}$ & \\
\hline $\begin{array}{l}\text { Occupational safety } \\
\text { Reduction in the incidence of industrial injuries with lost working days to less than two per million } \\
\text { hours worked, see also page } 76\end{array}$ & \\
\hline $\begin{array}{l}\text { Climate protection } \\
\text { Restriction of global greenhouse gas emissions (metric tons of } \mathrm{CO}_{2} \text { equivalents) to the } 2007 \text { level } \\
\text { through } 2020 \text { despite an increase in production, see also page } 93\end{array}$ & \\
\hline $\begin{array}{l}\text { Energy-efficient production process } \\
\text { Optimization of a production process for monomer diisocyanate with the goal of reducing energy } \\
\text { consumption by about } 15 \text { percent }\end{array}$ & \\
\hline $\begin{array}{l}\text { Emissions into air } \\
\text { Reduction in VOC (volatile organic compounds) emissions by } 30 \text { percent per metric ton of sales } \\
\text { product, see also page } 94\end{array}$ & \\
\hline $\begin{array}{l}\text { Protection of the ozone layer } \\
\text { Adherence to a maximum threshold of less than } 20 \text { metric tons of ODS (ozone-depleting } \\
\text { substances) emissions per year (CFC } 11 \text { equivalents), see also page } 94\end{array}$ & \\
\hline $\begin{array}{l}\text { Emissions into water } \\
\text { Reduction in the discharge of TOC (total organic carbon) and nitrogen into receiving waters by } \\
10 \text { percent per metric ton of sales product, see also page } 95\end{array}$ & \\
\hline $\begin{array}{l}\text { Waste } \\
\text { Reduction in the volume of waste requiring special supervision (hazardous waste) to less than } \\
2.5 \text { percent per metric ton of sales product, see also page } 97\end{array}$ & \\
\hline
\end{tabular}

The full program of objectives 2006+ including the status of implementation and the degree of achievement in 2009 can be found on the Internet in our list of links under point 19.

WWW 9 un Global Compact | 10 Mission statement | 11 Bayer Sustainability Program 12 Bayer Sustainable Development Policy | 13 Bayer Human Rights Position 14 Bayer Corporate Compliance Policy I 15 Responsible Care I 16 Certifications and memberships 17 Sustainable procurement management | 18 Supplier Code of Conduct | 19 Objectives 2006+ 


\section{Step-by-step development of sustainability in the company}

\begin{tabular}{|c|c|c|}
\hline & Strategic steps & Projects and measures \\
\hline $\begin{array}{l}\text { Through } \\
2012\end{array}$ & $\begin{array}{l}\text { Systematic integration of sustainability into } \\
\text { businesses, functions and regions }\end{array}$ & $\begin{array}{l}\text { - Expansion of Sustainability Program } \\
\text { - Further development of the "Access to Medicine" } \\
\text { strategy } \\
\text { - Climate Program } 2.0 \\
\text { - Initiative for plant and process safety }\end{array}$ \\
\hline $\begin{array}{l}2008- \\
2010\end{array}$ & $\begin{array}{l}\text { 2009/2010: Further development of Bayer's sustain- } \\
\text { ability strategy and program } 2009 \\
\text { 2009: Directives on process and plant safety, } \\
\text { occupational safety and occupational health } \\
\text { 2009: Code of Conduct for Responsible Lobbying } \\
\text { 2008: Corporate CompliancePolicy } \\
\text { 2008: Expansion of the strategy for sustainability in } \\
\text { procurement }\end{array}$ & $\begin{array}{l}\text { 2010: } \\
\text { - Roll-out of sustainability check } \\
\text { - Roll-out of the STRUCTese }{ }^{\circledR} \text { energy efficiency } \\
\text { management system } \\
\text { - Bayer Climate Program: further implementation } \\
\text { 2009: Roll-out of the Bayer Supplier Code of Conduct } \\
\text { 2009: Implementation of the Climate Check } \\
\text { 2008: Support for the CEO Water Mandate and "Caring } \\
\text { for Climate" initiatives of the UN Global Compact } \\
\text { 2008: REACH implementation } \\
\text { 2008: First presentation of the Bayer Climate Award }\end{array}$ \\
\hline $\begin{array}{l}2006- \\
2007\end{array}$ & $\begin{array}{l}\text { 2007: Launch of the Bayer Climate Program } \\
\text { 2006: Sustainable Development Policy } \\
\text { 2006: Signing of the Responsible Care Global Charter }\end{array}$ & $\begin{array}{l}\text { 2007: Bayer Anti-Corruption Year } \\
\text { 2007: Bayer Group positions on the themes of human } \\
\text { rights, biomonitoring, the responsible use of gene } \\
\text { technology and nanotechnology } \\
\text { 2007: Bayer Code of Good Practice on Nanomaterials } \\
\text { 2006: "Triple-i" innovation initiative }\end{array}$ \\
\hline $\begin{array}{l}2003- \\
2005\end{array}$ & $\begin{array}{l}\text { 2005: Directive on Health, Safety, Environment and } \\
\text { Quality (HSEQ) Audits } \\
\text { 2004: Formulation of a mission statement, values and } \\
\text { leadership principles for the Bayer Group } \\
\text { 2003: Development of a strategy for sustainable } \\
\text { agriculture }\end{array}$ & $\begin{array}{l}\text { 2005: Launch of systematic initiatives to reduce child } \\
\text { labor in India } \\
\text { 2004: Sustainability committees anchored in the } \\
\text { Bayer Group organization } \\
\text { 2004: Organizational stakeholder in the Global } \\
\text { Reporting Initiative (GRI) } \\
\text { 2003: Definition of key performance indicators for } \\
\text { health, safety and environment (HSE) }\end{array}$ \\
\hline $\begin{array}{l}\text { Before } \\
2002\end{array}$ & $\begin{array}{l}\text { 2001: Guidelines for Responsible Care in Environ- } \\
\text { mental Protection, Health Protection and Safety } \\
\text { 2000: Bayer is a founding member of the UN Global } \\
\text { Compact } \\
\text { 1986: Policy guidelines for environmental protection } \\
\text { and safety }\end{array}$ & $\begin{array}{l}\text { 2000: Registration of all production sites in the } \\
\text { Bayer Site Information System BaySIS }{ }^{\circledR} \text { introduced in } \\
\text { 1999 to determine HSE key performance indicators } \\
\text { 1998: Policy guidelines for the responsible use of } \\
\text { genetic engineering } \\
\text { 1995: Launch of the Agrovida program to improve } \\
\text { the living and working conditions of rural laborers in } \\
\text { Brazil } \\
\text { 1987: Launch of a DM3 billion program to improve } \\
\text { environmental protection }\end{array}$ \\
\hline \multicolumn{3}{|c|}{$\begin{array}{l}\text { External evaluations: } \\
\text { 2009: Top ten placement in the European Good Company Ranking of manager magazin } \\
\text { Since 2005: Annual inclusion in the Climate Disclosure Leadership Index of the Carbon Disclosu } \\
\text { company worldwide" in } 2009 \\
\text { Since 2001: Uninterrupted inclusion in the FTSE4Good Global } 100 \text { and ASPI Eurozone Index } \\
\text { Since 1999: Uninterrupted annual inclusion in the global Dow Jones Sustainability Index (DJSI) }\end{array}$} \\
\hline
\end{tabular}




\section{"Sustainability opens up new business opportunities"}

Bayer has performed relatively well in the global financial and economic crisis and, in the difficult environment of 2009, was even able to achieve the company's thirdstrongest operating result ever. What role did aligning the corporate strategy more strongly to sustainability play in this?

A very crucial one. After all, ideas and action at Bayer have always been focused on long-term success. We have oriented the Group's strategy to the development of approaches for tackling the major megatrends. This strategy has proven to be the correct one in view of the crisis that now hopefully lies behind us. Innovation is the driving force in our sustainability-focused corporate strategy. We consider the development of viable solutions for the future as a duty and an opportunity. This long-term approach is a key aspect of sustainability.

What part can employees play in your opinion?

Our employees naturally have a key role to play. Without their innovative strength and motivation, our strategies would be doomed to fail. That's why it is so important to support both - for example by enabling employees to share in the company's success or stepping up activities in the fields of occupational safety and health protection and introducing measures to deliver a sounder work/life balance. We are thus committed to a responsible human resources policy that results in us attracting the best and most innovative employees to the company and retaining them. If we manage this, each of our over 100,000 employees will then act as ambassadors for our company.

You unveiled an extended sustainability strategy in November 2009. What does this involve?

First off, I feel it is important to build on what we have already achieved. For there is one thing we are proud of: sustainable development at Bayer has a long tradition, our commitment here is acknowledged globally by many stakeholders. But we don't want to and won't rest on our laurels. Our updated sustainability strategy is based even more firmly on our core skills and our portfolio. We have used global trends and the resulting challenges as a starting point and are focusing our commitment on three key areas - health care, nutrition and protecting the climate and resources. Our areas of activity in eight international lighthouse projects currently show how Bayer can harness its expertise to make effective contributions to sustainable development.

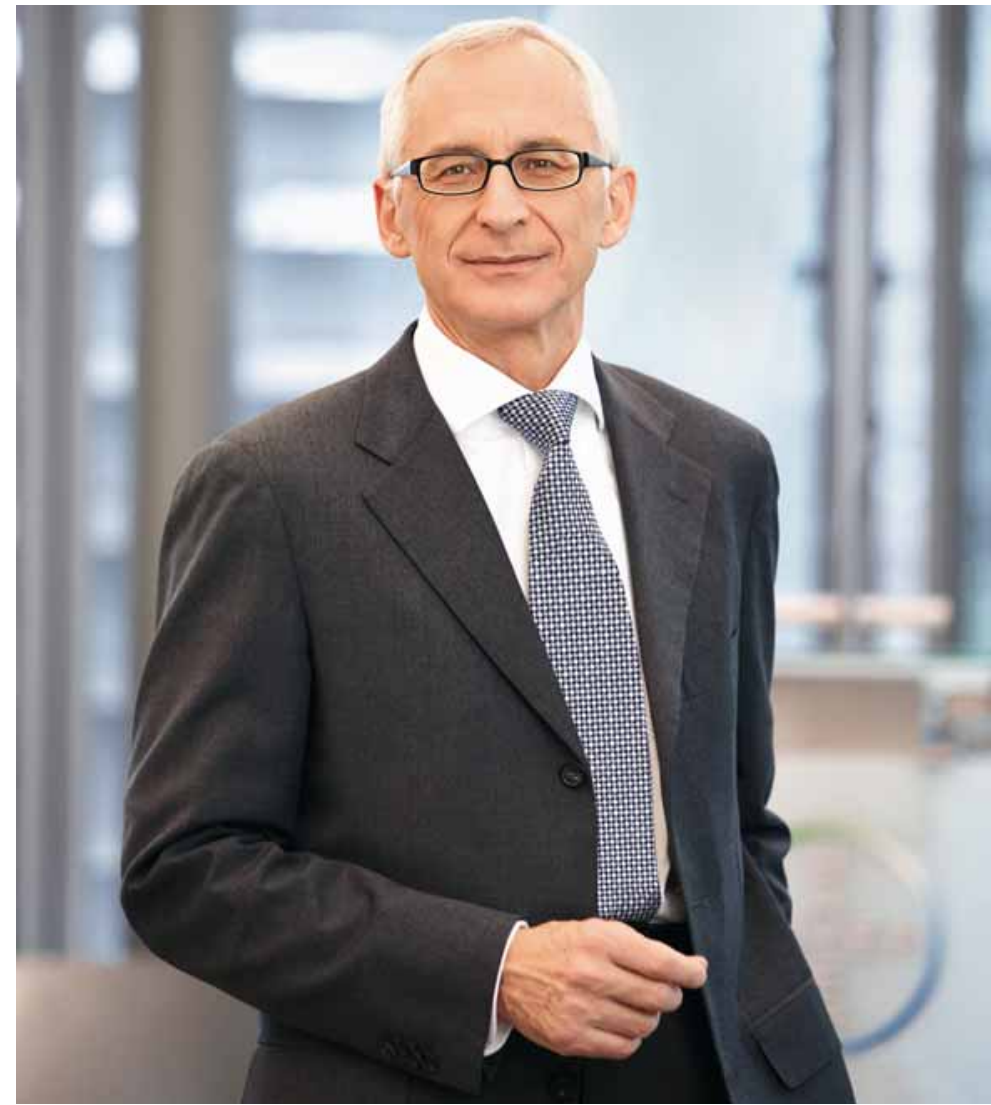

Dr. Wolfgang Plischke, member of the Board of Management of Bayer AG responsible for Innovation, Technology and Environment and for the Asia/Pacific region

What form do these contributions take?

Let's take food as an example. The demand for food will continue to rise, whereas agricultural land will decrease in area. What's more, the progression of climate change is threatening crops and harvests, due to factors such as extreme weather conditions and growing populations of harmful insects in certain regions. Sustainable agriculture will only be possible in the future through the integrated use of crop protection agents and innovative seeds...

... but it will also need to be able to feed farmers in those regions.

Indeed. And that's why we have launched a program to champion a new cultivation method in Indonesia - where 
over 40 million people live from the staple food crop rice that aims to achieve sustainable improvement in the crop yield and income of the country's rice farmers. As part of its integrated approach, Bayer is supplying the requisite sowing machinery along with expertise and crop protection agents.

Sharing knowledge and experience is also at the heart of your Food Chain Partnerships concept. How do you proceed here?

Food Chain Partnerships bring together all players in the value added chain - i.e. those involved in the production, processing, transportation and sale of food. This concept also forms the basis for our lighthouse project in Indian vegetable cultivation. We support local and sustainable farming structures with the aim of ensuring that consumers get the best quality. At the same time, the Indian farmers improve their income. It's a partnership that benefits everyone.

Partnerships seem to be becoming increasingly important for Bayer.

Absolutely. We are entering into partnerships in the most disparate of fields. This can be seen, for example, in our dealings with various players in the business world. In our view, these should always have a partnership-based character. And we are thoroughly committed to partnershipbased collaboration to help achieve solutions together.

\section{Could you give us an example?}

Let's take health. The major challenge of delivering global health care can only be overcome through partnership. Our alliances for sustainable health care address this head-on. For instance, as part of our "Family Planning" lighthouse project, we work closely with partners such as the German Foundation for World Population (DSW) and the United States Agency for International Development (USAID). In Africa, we have joined forces in launching contraceptives onto the market at prices that are affordable for the local population. And in the World Health Organization (WHO) we have a strong partner in the fight against neglected diseases.

In the light of climate change, many people strongly associate sustainability with emissions and responsibility for the environment. How do you carry through this responsibility? Although we already reduced our absolute greenhouse gas emissions in the Group by 32 percent between 1990 and 2005 through a whole raft of measures, we have now set ourselves new ambitious targets. In the Bayer MaterialScience subgroup, for example, which is responsible for around 80 percent of Bayer's energy consumption, we have committed to reduce specific emissions by a further 25 percent by the year 2020 . We also want to control the use of resources even more effectively. We are therefore currently testing our Resource Efficiency Check in pilot projects. The aim here is to identify steps in the production process and processing procedures that can be used to further enhance the resource efficiency of, for example, starting materials, water and solvents.

But can Bayer products also be of direct help in conserving resources?

Definitely. Bayer MaterialScience offers numerous examples of this. The product portfolio in this field of activity ranges from cutting-edge insulating materials and hightech films to energy-saving lighting elements, enabling us to play a direct role in energy-efficient design. It is against this backdrop that we also created the "EcoCommercial Building" lighthouse project - after all, 20 percent of global greenhouse gas emissions can be attributed to the energy consumption of buildings. In this project, we integrate all players in building construction and promote the use of construction materials that further reduce emissions.

But this also means sustainable products are important for your business, doesn't it?

Naturally. Sustainability opens up fresh business opportunities - and we are harnessing these, for example in the development of health care markets worldwide or through research into stress-resistant plants. I am also convinced that demand for sustainably produced goods will increase, just as consumer awareness of sustainability issues will also rise. This continuously spurs us on to bring to market innovative products in all areas of our business that will satisfy this demand. And we are already helping to do this today with our new tool for measuring the contribution that our products make to sustainability.

A number of your sustainability objectives relate to 2010 what will happen from 2011 onwards?

We'll be working on two areas. We will continue to offer transparent reporting on our target attainment in the future. And we will formulate new, ambitious goals. After all, we do not consider sustainability a mere passing phase but something that needs to be integrated into our business. We will be rigorous in pursuing this strategy. 


\section{In dialogue with our stakeholders}

As an internationally operating company, we know that social acceptance of business activities cannot be achieved without communication with stakeholders in transparent and open dialogue. Sustainability and mutual acceptance can only be attained together.

That's why we specifically seek dialogue at the local, national and international levels with representatives from politics, industry and society. Our conversation partners are our stakeholders - employees, customers, suppliers and investors. Of equal importance to Bayer are public interests - those of our direct neighbors at our sites and of non-governmental organizations (NGOs), politicians and the general public. Last but not least, Bayer operates within a scope of activity that is heavily influenced by scientific institutions and public administration bodies, as well as by legislation.

We see dialogue with our various stakeholders as the basis for building mutual understanding and trust, and as an opportunity to openly communicate to each other points of view and courses of action. It helps us to identify challenges and view them from various perspectives. We want cooperative dialogue to create value for all partners. We take the suggestions of our stakeholders seriously, as they provide important impulses for our company. They help us to avoid risks, as well as to recognize at an early stage both trends and markets - and thus also to define focus areas for our activities. Systematic dialogue therefore makes an important contribution to both innovation and risk management. This results in sustainable solutions that account for a broad spectrum of interests.

Our Sustainability Program illustrates the implementation of this conviction: all our lighthouse projects in the areas of health care, nutrition and climate change are based on dialogue and partnership (see page 3of.).

\section{Intensive cooperation}

We work closely with our stakeholders on a number of initiatives. The topics of these initiatives and the perspectives of the various stakeholder groups are extremely diverse. Although sustainability issues are global, they can vary widely with respect to regional priorities or perspectives. We constantly strive to view the various challenges in a dif- ferentiated manner and take account of context in order to develop solutions on a case-by-case basis that satisfy the framework conditions. For this reason, stakeholder dialogue is an important task for the various functions, organizational units and regions.

Our stakeholder activities range from local projects through participation in committees and specialist workshops to comprehensive information programs and collaboration in international initiatives. The table on the right provides examples of the activities we participate in with various stakeholder groups.

\section{Analysis of stakeholder feedback}

We regularly verify that our reporting satisfies the information needs and concerns of our stakeholders. Between June 2009 and January 2010, some 250 of our most important stakeholders (NGOs, associations, regulatory authorities, analysts and investors, customers, suppliers and politicians) took part in our global online survey. This survey determined, among other factors, which sustainability issues are considered to be of particular importance to our stakeholders as regards Bayer. The results confirm that Bayer focuses on the right societal megatrends: a responsible approach to drinking water, children's health, energy-efficient and environmentally friendly production and innovation are viewed as crucial issues, as are climate change and climate protection, sustainable health care and safety at the workplace. The transparent implementation of these issues is detailed particularly clearly in the focus issue sections but is also demonstrated in the Performance Report.

The stakeholders' preferred method of dialogue is discourse in discussion events, followed by issue-related workshops and discussion sessions with individual stakeholder groups. We aim to further expand these communication channels in the future.

To further improve and more tightly shape dialogue with our stakeholders, we are currently working with HHL (Leipzig Graduate School of Management) on a project aimed at developing a new approach to stakeholder analysis and prioritization, the results of which will be taken into account in our stakeholder management process. 


\section{Examples of dialogue with various stakeholder groups in 2009}

Employees

$\square$ Dialogue with sustainability experts (round table for Group Leadership Circle members)

$\square$ 18th European Forum: dialogue with local employee representatives

$\square$ Bayer Executive Sustainability Summit (USA)

$\square$ Managerial employee survey on sustainability issues

$\square$ Continuing education seminars for our employees in the areas of compliance, human rights, sustainability in purchasing, and diversity $\square$ Innovation Community Workshop

\section{International initiatives}

$\square$ Cooperation with the United Nations (UN): UN Global Compact with the initiatives "Caring for Climate" and CEO Water Mandate; United Nations Environment Programme (UNEP); Sustainable Buildings and Climate Initiative

$\square$ Collaboration by BHC with the U.S. Agency for International Development (USAID), the UN Population Fund (UNFPA) and the International Planned Parenthood Federation (IPPF)

$\square$ Organizational stakeholder in the Global Reporting Initiative (GRI)

$\square$ Participation in the WEC (World Environment Center)

\section{NGOs}

$\square$ Support of "HOPE" in the area of diabetes during a training supervisor project in India

$\square$ Project with the German Foundation for World Population (DSW)

$\square$ Collaboration with "Engender Health" in the area of contraception

$\square$ Cooperation with Vigyan Ashram, Prajayatna, Naandi and Vignana Jyothi in India on the "Learning for Life" initiative

$\square$ Biodiversity collaborations: "Ducks Unlimited" (United States), "Stiftung Rheinische Kulturlandschaft" (Germany), "Sociedade Humana Despertar" (Brazil)

$\square$ Cooperation with and assistance of "Die Arche e.V." children's and youth welfare organization in Berlin

\section{Science and research}

$\square$ Cooperation by BCS with the Commonwealth Scientific and Industrial Research Organisation (CSIRO) on wheat research

$\square$ Cooperation by BCS with the China National Rice Research Institute (CNRRI) and the International Rice Research Institute (IRRI)

$\square$ Participation in scientific bodies such as the Society of Environmental Toxicology (SETAC), the International Life Science Institute/Health and Environmental Science Institute (ILSI/HESI) and the European Center for Ecotoxicology and Toxicology of Chemicals (ECETOC)

$\square$ Partnership of BHC in the Juvenile Diabetes Research Foundation (JDRF)

$\square$ Forums and conferences with participation by industry and government in cooperation with the Chanzhou Coatings Research Institute (China)

$\square$ Professorships at universities in the fields of medicine, pharmacy and chemistry

$\square$ Strategic collaborations with universities in Cologne (Germany), the NUS (Singapore), Tsinghua University (Beijing, China) and the DKFZ (Heidelberg, Germany)

$\square$ Presentations and discussions on sustainability at BayKomm with visiting student groups from Germany and abroad

$\square \mathrm{BHC}$ as an industry partner to the international Graduate Research Training (GRT) Program on Pharmacometrics \& Computational Disease Modelling

$\square$ Assistance and presentation at the World Health Summit 2009 in Berlin

\section{Customers}

$\square$ Participation in the dialogue circle of the Global Automotive Stakeholder Group (BMS)

$\square$ Customer satisfaction survey for farmers and product dealers in Poland, Austria and the Netherlands (BCS)

$\square$ Customer satisfaction survey (farmers) on Arize ${ }^{\circledR}$ hybrid rice in Vietnam (BCS)

$\square$ Participation in World Diabetes Day and World Contraception Day through presentations and activities (BHC)

\section{(Industry) associations}

$\square$ Chairmanship of the European Federation of Pharmaceutical Industries and Associations (EFPIA)

$\square$ Chairmanship of the German Association of Research-Based Pharmaceutical Companies (VFA)

$\square$ Participation in numerous national, European and international associations, including the Federation of German Industries (BDI), the German Chemical Industry Association ( $\mathrm{VCI}$ ), the American Council on Chemistry (ACC) and the European Chemical Industry Council (CEFIC)

$\square$ Continuous participation by the subgroups in their respective industry associations

$\square$ Membership of the Board of Management of the sustainable development forum of German industry (econsense)

\section{Public-private partnerships}

$\square$ Collaboration with the WHO in the area of "neglected tropical diseases" (Chagas, African sleeping sickness)

$\square$ Global Alliance for TB Drug Development (tuberculosis)

$\square$ Collaboration with the initiative "Drugs for neglected diseases" (DNDI)

$\square$ Cooperation on malaria issues with the International Vector Control Consortium (IVCC), part of the Bill \& Melinda Gates Foundation (BMGF)

\section{Politics}

$\square$ Participation by BHC in the EPAA (European Partnership for Alternative Approaches to Animal Testing)

$\square$ Participation by BMS in the "NanoDialog" between the German government and industry

$\square$ Participation by $\mathrm{BHC}$ in a dialogue event for water protection in North Rhine-Westphalia

$\square$ Anti-cancer workshop featuring the E.U. Health Commissioner and E.U. parliamentarians (BHC)

$\square$ Brussels Academy: dialogue platform of BCS in cooperation with the European Training Institute

\section{Society/Neighborhood}

$\square$ Sustainability News Conference

$\square$ Bayer experts' round table on sustainability featuring international speakers

$\square$ "Brainstorming for Berlin" dialogue series (BHC)

$\square$ Discussions with neighbors, public authorities and elected officials on topics such as the CO pipeline (BMS/Currenta)

$\square$ "Chemistry is the future" dialogue series between the German Mining, Chemical and Energy Industrial Union (IGBCE) and BMS

$\square$ Neighborhood dialogue with local government representatives, companies and residents at the BHC site in Shiga, Japan

\section{Investors/Analysts}

$\square$ Meet Management 2010 - investors and analysts pursue direct dialogue with Bayer management

$\square$ Participation in the task force of the Society of Investment Professionals in Germany (DVFA) for the development of non-financial reporting indicators

$\square$ Participation in podium discussions/events on the subject of sustainable investment

\section{Schools}

$\square$ Expansion of the Bayer education program "Making Science Make Sense"

$\square$ “Baylab" school laboratories with programs maintained by the subgroups in Leverkusen, Monheim, Berlin and Wuppertal (Germany)

$\square$ “Bayerchios Program" in Colombia: promotion of scientific teaching at public schools by Bayer employees

\section{Suppliers}

$\square$ Supplier Days 2009: e.g. Bayer HealthCare in China and Germany

$\square$ Logistics suppliers workshop on transport safety in China (BMS)

$\square$ Annual presentation of a supplier award for outstanding sustainability performance by Bayer suppliers in India 
The 30 Focusissue MAN H

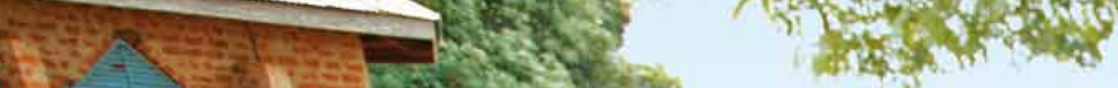

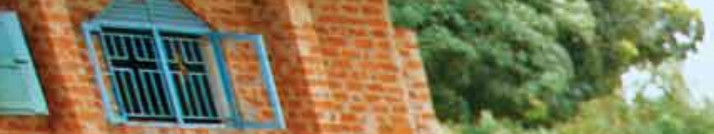

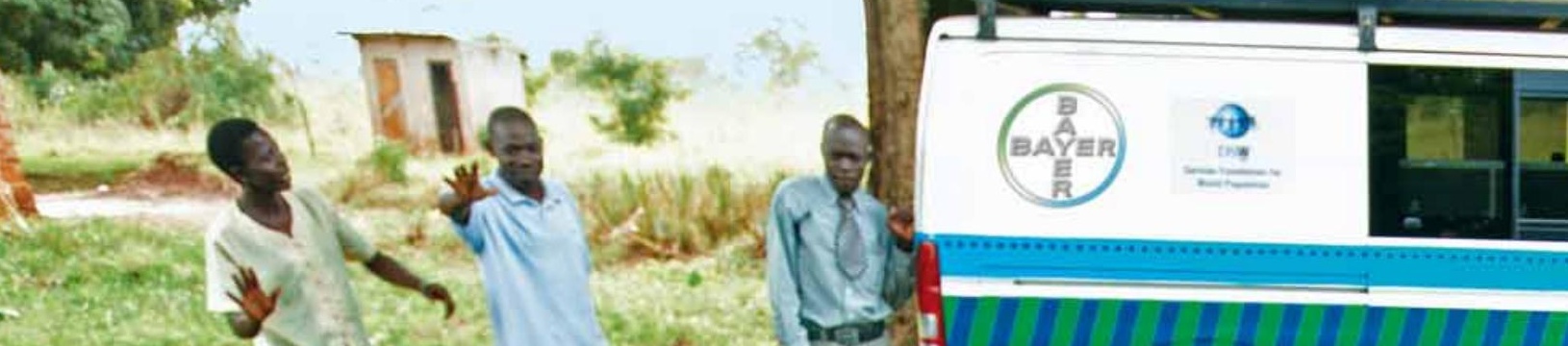

a $-1-1$

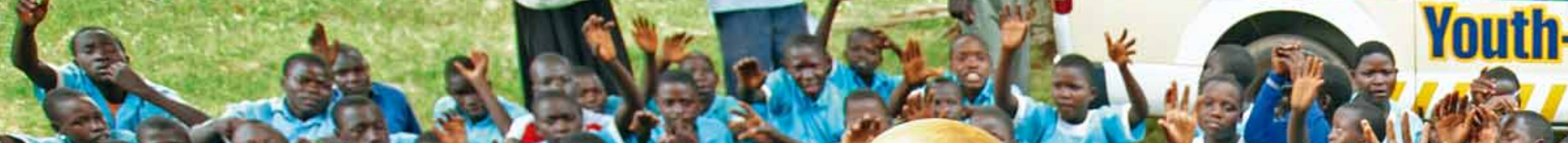
3 ang ras

T.

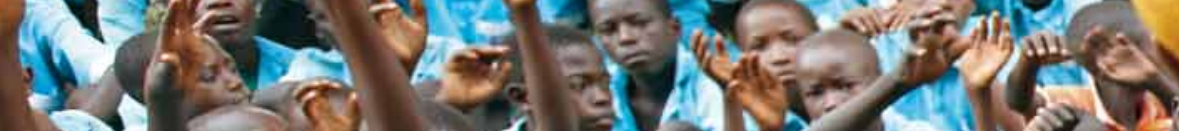

J

J

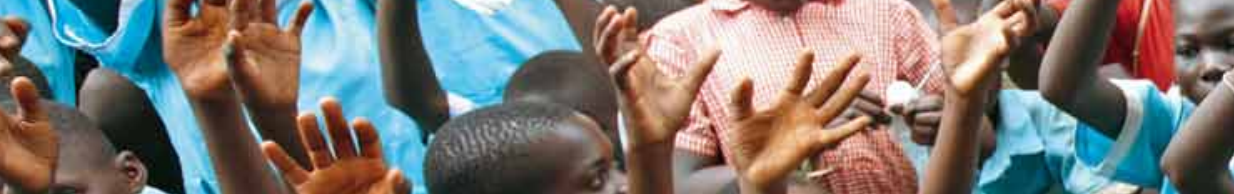

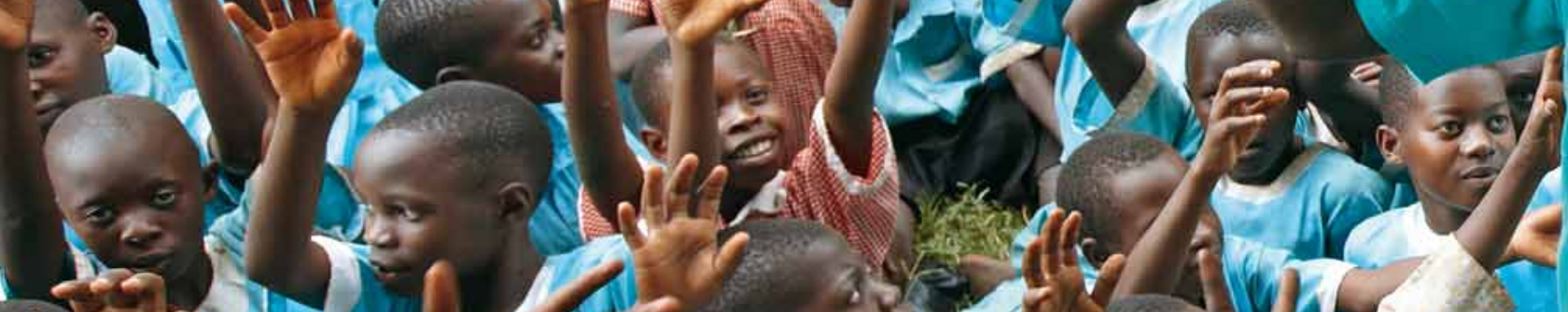

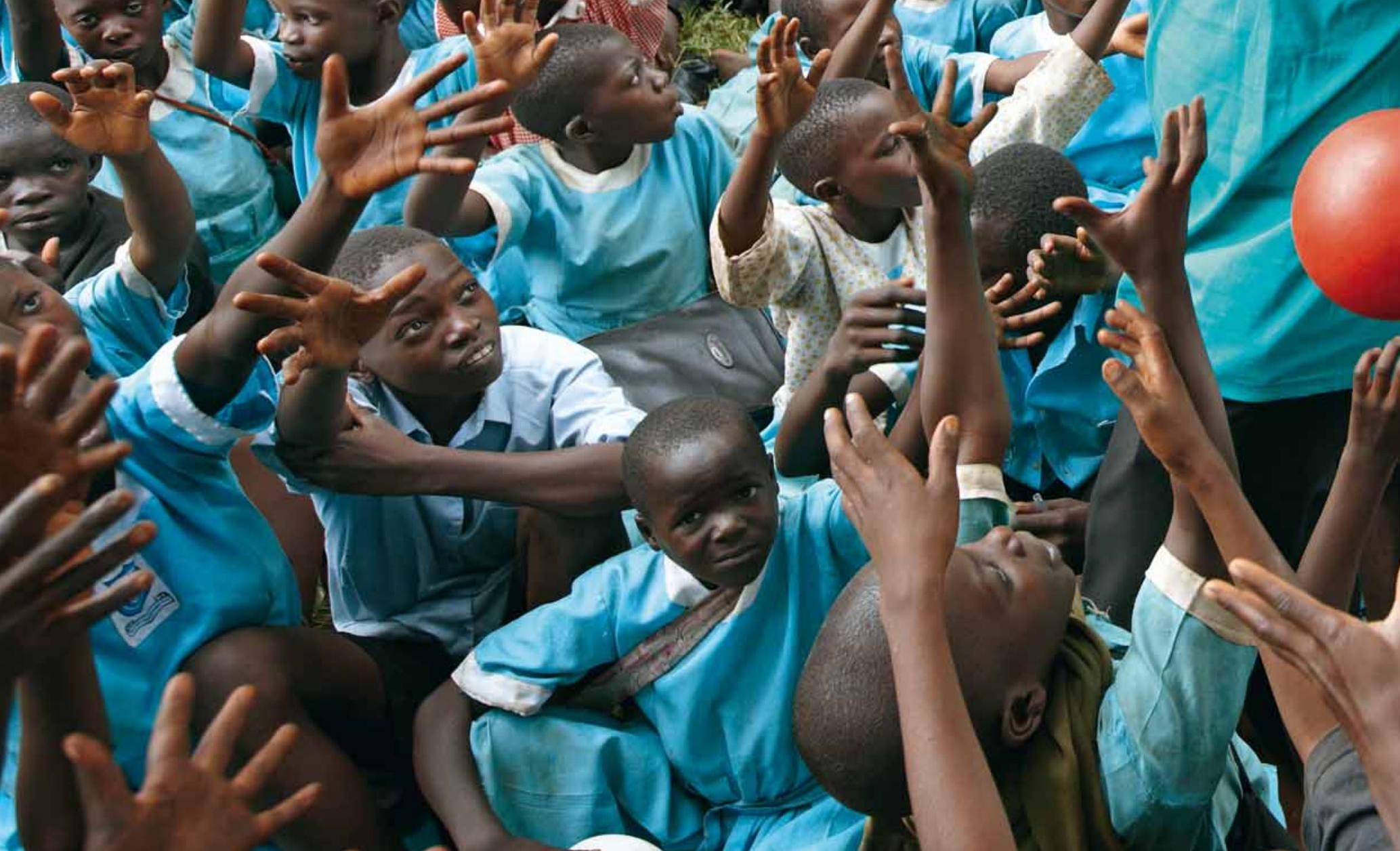




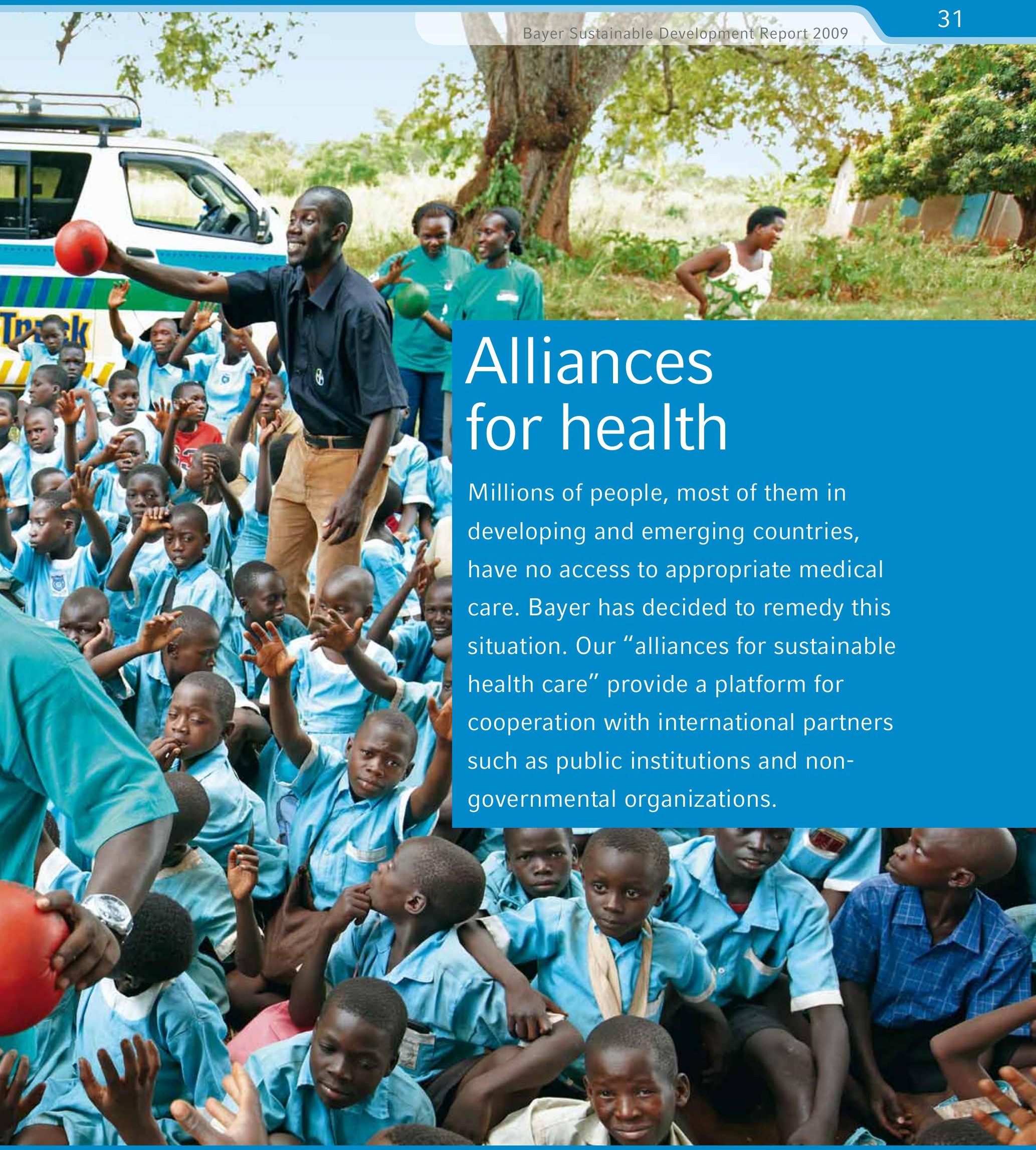

Compared to many of their contemporaries, young people in Africa are extremely reluctant to talk about issues of sexuality. This is because all matters relating to this topic are taboo in their culture. It is therefore particularly important that they are educated in topics such as sexuality, contraception and HIV/AIDS at an early age. Uganda, for example, has the highest birth rate in Africa. On average, women in this country give birth to seven children. Most pregnancies are unwanted. Bayer HealthCare has teamed up with the German Foundation for World Population (DSW) to provide a pioneering sex education program for teenagers under the age of 15. David Kafambe and his colleagues from the DSW take the "Youth Truck" to areas where they are sure to find young Ugandans - schools, marketplaces and youth centers. They use games to coax the young people out of their shell: the first person to catch the ball asks a question that interests them about sexuality. Then the ball is thrown to the next teenager, who then has the opportunity to pose the next question. More information is provided each time the ball is caught, giving the teenagers a better insight into this important topic. 
Self-determined family planning program

Self-determined family planning is still a taboo subject in many developing and emerging countries. Many women have unplanned pregnancies, often at a very young age. According to the World Health Organization (WHO), 1,500 women die every day as a result of complications during pregnancy and childbirth. 10,000 children worldwide die every day during their first few months of life, 99 percent of them in developing countries. As part of its Sustainability Program, Bayer intends its lighthouse project "Family Planning" to make a substantial contribution to helping

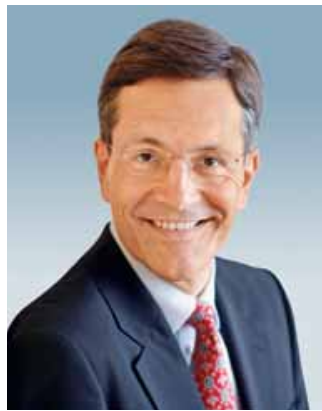

Dr. Ulrich Köstlin, member of the Executive Committee of Bayer HealthCare

"Our commitment to sustainable health care is important for our business development, and it is a central element of our corporate responsibility."

women to plan their lives themselves. A fundamental aspect of family planning is access to contraceptives. Working with partners such as the United Nations Population Fund (UNFPA) and the International Planned Parenthood Federation (IPPF), Bayer hopes that the provision of more health information and education will reduce the risks associated with unplanned pregnancies and unsafe termination of pregnancy.

The Group's commitment is a contribution towards achieving the Millennium Development Goals of the United Nations (UN). These goals, which should be achieved by 2015, commit the global community to reducing child mortality, improving maternal health and supporting gender equality. But the challenges are considerable. The WHo estimates that of the 210 million or so pregnancies which occur in the world every year, around 38 percent are unplanned and 20 percent are terminated. That's more than 40 million terminations annually, most of them in developing countries.
Cooperation facilitates access to contraception

The "Family Planning" lighthouse project draws on the many years of experience that Bayer HealthCare (BHC) has with contraception. "But our objective is not only to bring reliable, low-risk methods of contraception onto the market," explains Dr. Ulrich Köstlin, a member of the Bayer Schering Pharma AG Board of Management and of the Bayer HealthCare Executive Committee. "We are also aware how important it is to provide comprehensive information about the benefits and risks of contraceptives and on how to use them correctly. Another factor is that the price of contraceptives is a challenge in many countries. Bayer therefore also takes into account the low purchasing power in developing countries in particular." The prices of contraceptives must be adjusted to patients' income, and are an essential factor in giving patients access to medical care.

In September 2009, BHC concluded a model cooperation agreement with the United States Agency for International Development (USAID). In this agreement, the company undertakes to market an oral contraceptive at a reduced price in a number of developing countries in Africa so that women with a low income can afford the original product. This initiative will begin with the oral contraceptive Microgynon ${ }^{\circledR}$ Fe in Ethiopia, followed by Tanzania and Uganda. Eight further African countries will be included by 2012 .

This is the first time that a government organization has cooperated with a manufacturer to make available a lowprice oral contraceptive to women in Ethiopia. "We will work with USAID in this region to create conditions under which patients can be educated, the product can be distributed, and health care professionals can be trained," says Klaus Brill, Head of the Corporate Commercial Relations function. We will be launching numerous family planning programs with the aim of doubling our current joint activities in this field by 2012 . For example, we will be providing up to 110 million monthly cycles of oral contraceptives annually so that eight million women in developing countries can use reliable contraception every year.

\section{Partnerships for sex education}

According to WHO statistics, around 16 million children are born every year to mothers who are between 15 and 19 years of age. More than 90 percent of these mothers live in developing or emerging countries. In these countries, there is very often a lack of knowledge on sexuality and contraception methods and the topic is frequently seen as taboo. Yet knowledge, education and explanation are vital elements in empowering women to determine their 


\section{Objectives of Bayer's Sustainability Program}

\section{Lighthouse project "Family Planning"}

- Introduce original contraception products at prices in line with the market in 11 African countries jointly with USAID by 2012

- Double current family planning activities in collaboration with our partners (e.g. USAID, UNFPA, IPPF) by 2012

- Increase annual provision of oral contraceptives to 110 million cycles jointly with partners (e.g. USAID)

Lighthouse project "Neglected Diseases"

- Support the WHo in tackling Chagas and treating African sleeping sickness

- Research to shorten duration of tuberculosis therapy together with the Global Alliance for tB Drug Development

own lives and make their own family planning decisions. Bayer HealthCare's family planning program therefore also pursues another approach: we support comprehensive sex education. This includes the topic of HIV/AIDS, particularly in Africa. Our goal is to help children and adolescents to make a conscious decision to use contraception and to stop the spread of sexually transmitted diseases.

Bayer is participating in a project organized by the German Foundation for World Population (DSW), which runs sexual and reproductive health education programs in developing countries. The programs encourage young people to pass on their knowledge to their peers. "We approach the young people who visit the youth clubs which we have set up, and then spend five days teaching them to cope with sexuality, to use condoms, and to protect themselves against HIV/AIDS," explains Silke Rauschenbach from Dsw. "They put their new knowledge into practice using creative methods such as games, songs and little theater performances in schools and village communities." This approach also takes cultural differences into account. "The only way we can reach people here is through creativity. If we talk to them directly, they just walk away," explains Dsw employee David Kafambe.

Awareness of the fact that the "first time" can have farreaching consequences if contraception is not used is sadly also lacking in the industrialized countries. Some 25 percent of young women in the 14 to 24 age-bracket worldwide are not sufficiently well informed. This is why Bayer HealthCare also plays a part in World Contraception Day (WCD), celebrated every year on September 26. Initiated by 10 international organizations involved in sexual health, WCD creates a global platform for activities, initiatives and awareness campaigns. The global website at www.your-life.com is part of this education initiative.

Bayer HealthCare is involved in a further project which aims to increase awareness of the wide range of contraceptives available and to provide information on long-term contraception and sterilization. The RESPOND project (Responding to the Need for Family Planning through Expanded Contraceptive Choices and Program Services) launched by the non-governmental organization Engender Health in June 2009 is receiving support from Bayer HealthCare in the form of training material. It provides information on long-term contraception and sterilization for developing countries.

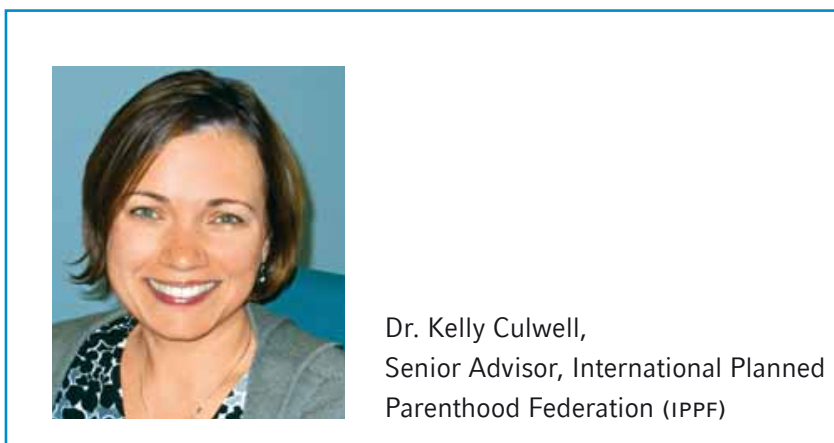

Self-determined family planning is a central aspect of maternal health and the development of entire societies. IPPF sees itself as a voice for women "which is dedicated to making the best methods of family planning available not only in privileged countries but to all women worldwide," Dr. Kelly Culwell explains. In African countries, in particular, there is a major need for improved family planning activities. "But in many parts of the continent we face political, logistical and often cultural difficulties."

The organization also champions engaging local communities in order to promote family planning, especially in developing and emerging countries. Reliable protection with contraceptives can only be ensured if they are used correctly. This means carrying out education and communication activities appropriate for the cultural context and in local languages. As IPPF is a federation of local organizations operating in 171 countries, the organization is able to utilize their knowledge, experience and trust gained with local communities to plan the appropriate family planning interventions. The need for improved family planning is not limited to developing countries. "We also need to invest more in more effective methods and more education in developed countries as well," Culwell adds.

IPPF welcomes Bayer HealthCare's global and wide-ranging commitment to family planning. Culwell is positive about the project currently being run in Uganda by Bayer HealthCare in collaboration with Dsw. "The key to success here is that the sponsors are working locally with trustworthy peers." 


\section{High-quality support}

Bayer HealthCare complies with the highest quality standards, a commitment that also extends to the medicines which it supplies to developing and emerging countries. For its contraceptive pills Microgynon ${ }^{\circledR}$ and Microlut ${ }^{\circledR}$ and the contraceptive implant Jadell ${ }^{\circledR}$ Bayer HealthCare has attained the prequalification status awarded by the World Health Organization (WHO). Through this, the wHo confirms that the preparations and their manufacture meet international standards in terms of efficacy, compatibility, quality etc. Bayer HealthCare is the first manufacturer of contraceptive products to be prequalified by the wHO.

\section{Drugs for "neglected diseases"}

The world's poorest people often suffer from diseases which are neglected by medical research. Against this background, Bayer HealthCare has designated a further lighthouse project to focus on tropical and neglected diseases. According to the WHo, more than 3.3 billion people, or in other words about half the world's population, are threatened by diseases such as African sleeping sickness, Chagas disease, malaria and tuberculosis. These conditions place a lasting burden on entire families or village communities.

Bayer HealthCare participates in aid programs to provide drugs for the treatment of these diseases which are included in the list of essential medicines drawn up by the World Health Organization (WHO).

To tackle African sleeping sickness, the company has been supplying 10,000 ampoules annually containing the active substance suramin for single-entity therapy of an early stage of the disease since 2003. In 2009, the company additionally started supplying, at no charge, 400,000 tablets per year of its drug Lampit ${ }^{\circledR}$; the active substance nifurtimox treats the advanced stage of African sleeping sickness. Since 2009, a further compound has been used in a combination therapy which opens up new perspectives in the treatment of late stages of the disease. The wHo included this combination therapy in the list of essential medicines in 2009.

Chagas disease, which is an infection transmitted in Latin America by a biting parasitic bug, claims around 14,000 lives every year. Bayer HealthCare has been collaborating with the WHO since 2002, annually supplying tablets of nifurtimox at no charge. In 2007, this cooperation agree- ment on the supply of 2.5 million tablets of Lampit ${ }^{\circledR}$ and support to the tune of us\$1.5 million for training and distribution was extended for a further five years.

"Our collaboration with the WHO is particularly important to us because it provides us with a specific way of reaching the people who are affected by these diseases," Köstlin explains. Our donations of Lampit $^{\circledR}$ and Germanin ${ }^{\circledR}$ to help control Chagas disease and African sleeping sickness are routed exclusively through the wHo. Bayer's Donation Directive stipulates compliance with the WHO's Guidelines for Drug Donations.

Tuberculosis is another "neglected disease." Around nine million new cases of active tuberculosis (TB) are reported every year. The wHo estimates that two million people die of the disease annually. Bayer HealthCare is working with the тв Alliance (Global Alliance for тв Drug Development) on the clinical development of a therapy option involving combination therapy with moxifloxacin, a drug substance produced by Bayer, which could reduce the duration of tuberculosis treatment from the present six months to four months. This would represent a substantial improvement for affected patients, who often stop taking the protracted and thus expensive treatment before it is completed. If their studies are successful, Bayer HealthCare and the тв Alliance will work towards making moxifloxacin available to tuberculosis patients at affordable prices, especially in developing countries which have a heavy burden of disease. In addition, we joined the "Critical Path to TB Drug Regimens" (CPTR) initiative in March 2010. This collaboration between industry, the authorities and NGOs is intended to accelerate the clinical development of тв therapies and to achieve faster regulatory approval of combination therapies.

Mosquito nets provide effective protection

Figures from the wHo show that some 3.3 billion people, or half the world's population, are at risk of developing malaria. Around 250 million people contract the infection every year, and almost a million die as a result. Climate change is expected to hasten the spread of tropical diseases such as malaria and dengue fever into regions which have not been affected by these parasites in the past. Researchers at Bayer CropScience were the first to find a way of incorporating the active substance deltamethrin, which the wHo recommends as protection against mosquitoes, into polypropylene fibers. The outcome of this work is a new textile fiber which can be used to make impregnated mosquito nets which are softer, stronger and stay effective for longer. The product, which goes by the brand name LifeNet ${ }^{\mathrm{TM}}$, is a long-lasting insecticidal net 
(LLIN) which is scheduled to reach the market in the next few years.

In 2009, Bayer CropScience concluded a forward-looking cooperation agreement with the Innovative Vector Control Consortium (IVCC) in Liverpool, United Kingdom. The objective of this project, which is initially planned to run for three years, is to discover new compounds effective against mosquitoes and other insects which are disease vectors. These compounds will be marketed as public health products (PHP) with the aim of protecting the health of the population. Bayer CropScience is contributing to this project its many years of experience and a comprehensive spectrum of substances and screening technologies. Bayer is opening its substance library - one of the most extensive in the world - for the first time as part of this collaboration.

Making innovative medicines universally available Successful innovative therapies and drug products are already available for many of the diseases which are becoming more prevalent especially in emerging countries. However, many patients in these countries have no access to these products and treatments. The first access program for Nexavar ${ }^{\circledR}$, a cancer treatment from Bayer HealthCare, was started in China in 2007. The drug is approved in the E.U. for the therapy of kidney and liver-cell carcinoma. The program gives cancer patients access to therapy with $\mathrm{Nexavar}^{\circledR}$ and covers the cost of the drug either for a limited period of time or for the full duration of therapy.

The program is now being extended to other countries, including India.

We will continue to pursue our strategy of "alliances for sustainable health care" and review the possibility of implementing it for other business units and regions. This includes the issues of market access and pricing concepts. The existing Bayer Social Healthcare Programs will remain a core activity here. In the future Bayer will maintain its innovative and research efforts, and will continue to enter alliances to intensify global partnerships and provide medicines for these projects. Bayer HealthCare's commitment is a contribution towards achieving the Millennium Development Goals announced by the United Nations.

\section{Malaria-affected regions}

Malaria is one of the most dangerous tropical diseases. According to the wHo, more than 880,000 people around the world die of malaria each year. Areas in Africa south of the Sahara are particularly badly affected by this disease. Here, a child dies every 30 seconds as a result of the Plasmodium parasite, which is transferred by the bite of the Anopheles mosquito. Drugs that can be taken by adults have become less effective due to resistance. Impregnated mosquito nets offer excellent protection, particularly for very young children.

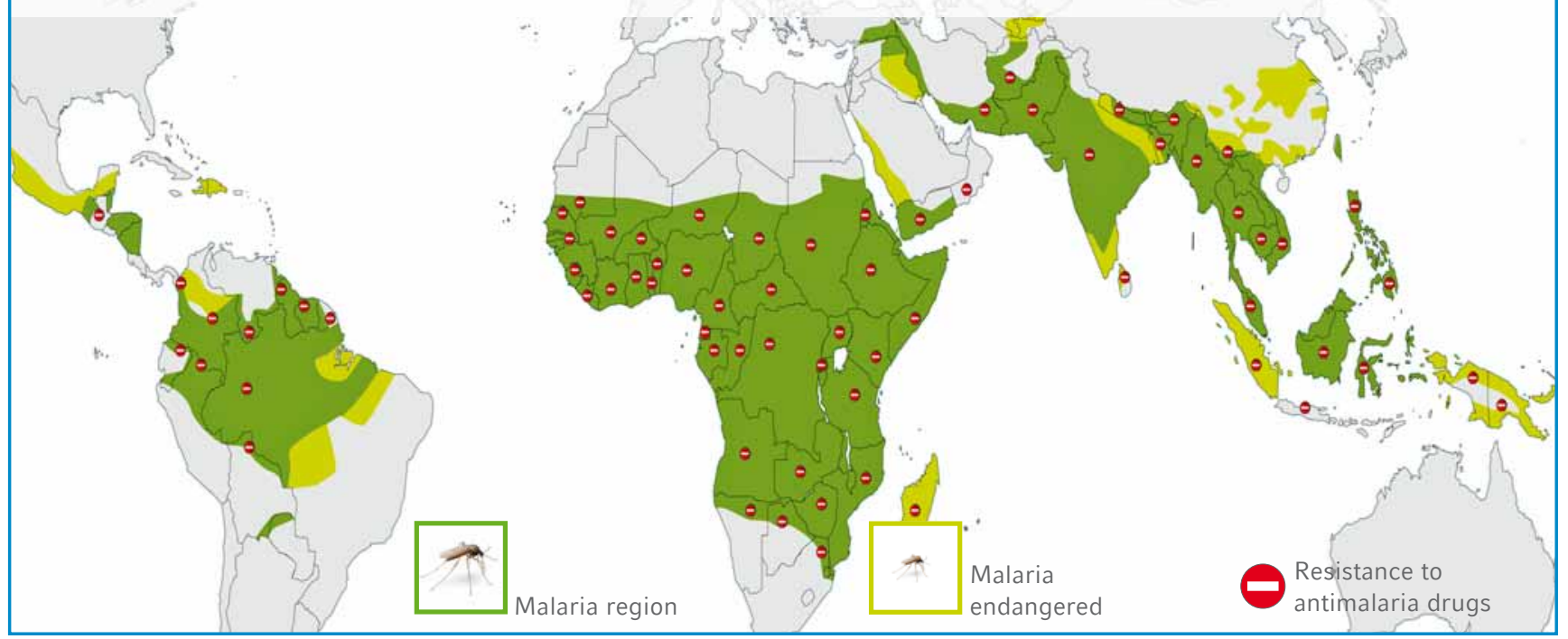

WWW 20 UNFPA | 21 IPPF | 22 WHO | 23 USAID | 24 DSW | 25 RESPOND | 26 Who prequalification | 27 TB Alliance 28 CPTR initiative I 29 IVCC 


\section{Partnerships for good harvests}

"High-quality food for everyone" is not just a slogan; it is a strategic objective of Bayer's Sustainability Program. The company has set itself the objective of becoming the global innovation leader - with sustainable solutions from sowing to harvest - and serves as a competent partner and consultant to all players involved in the production of food products.
1.720.

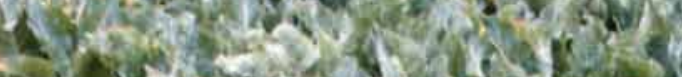
DNh 5 . S. Nof 2010 in

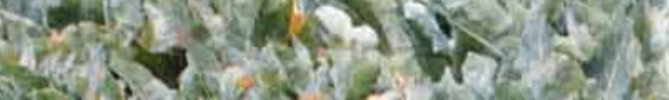

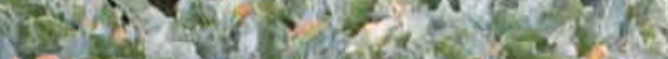
a $2 x-1,(2)$ (1) $\quad x=52$

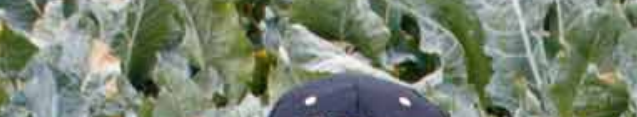
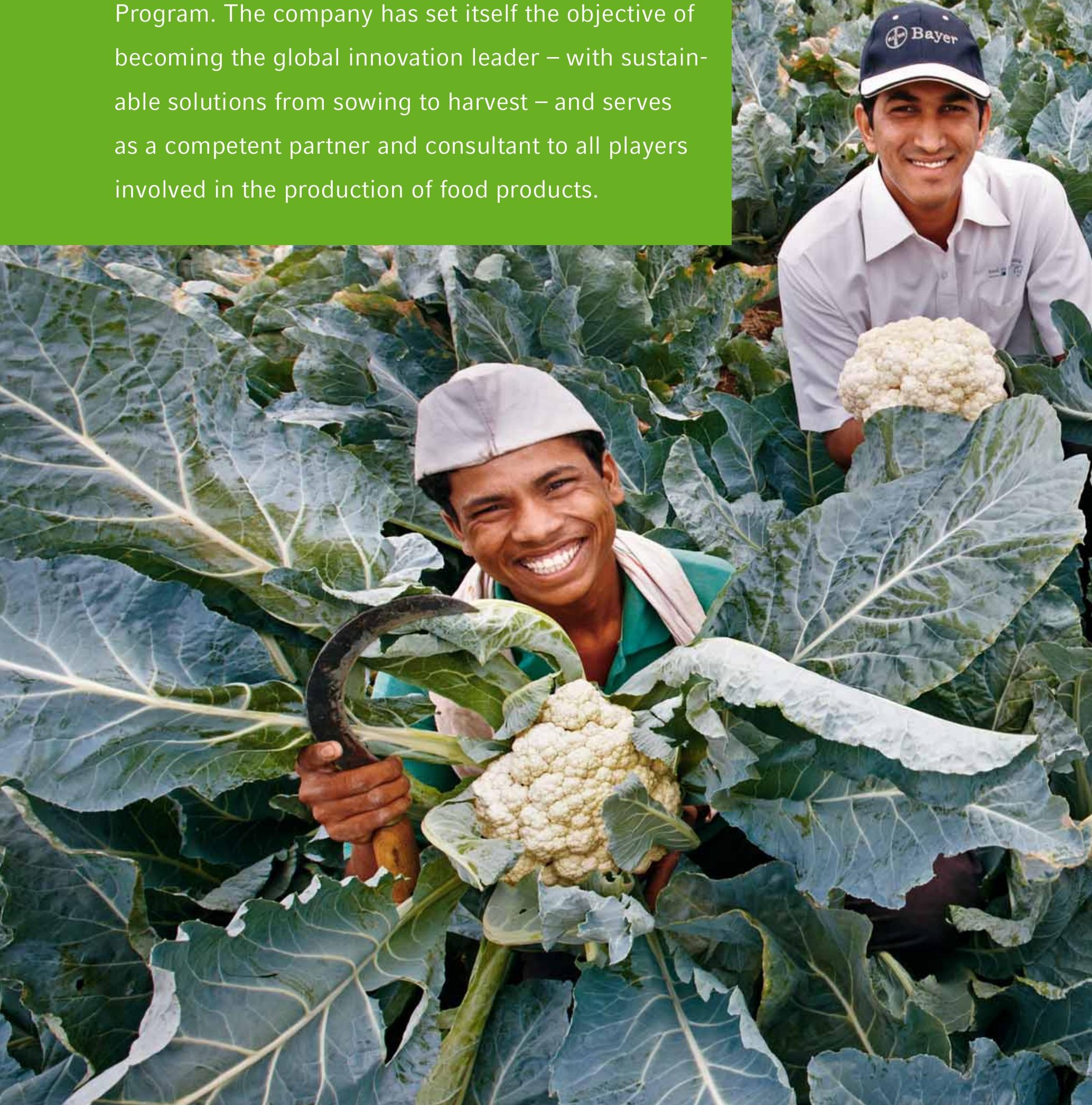


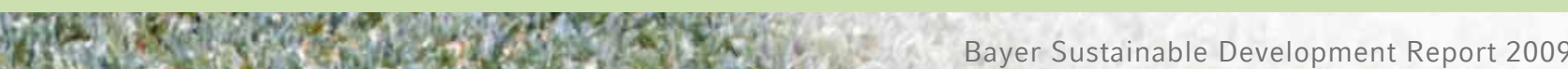

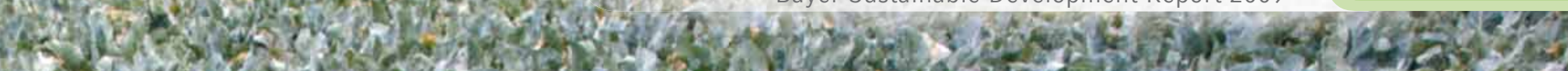

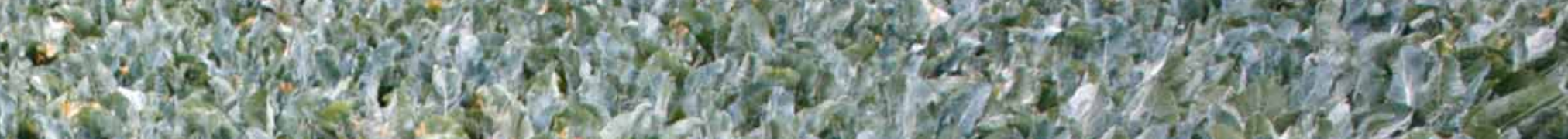

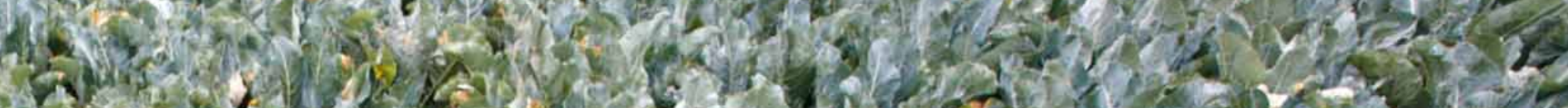

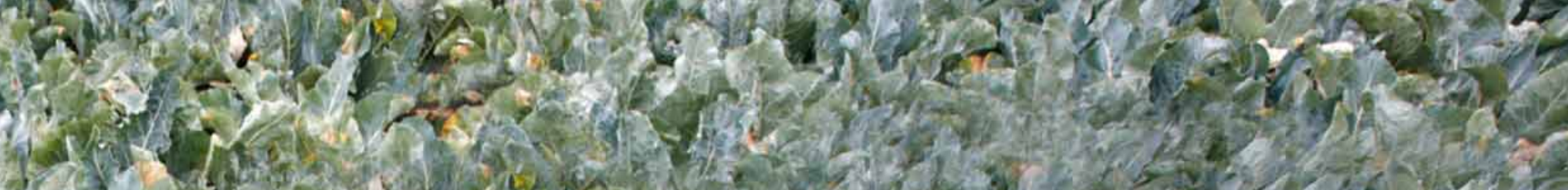
1.

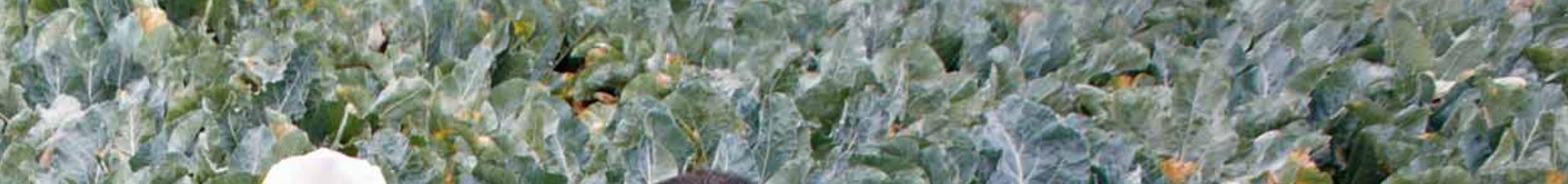
1.

(1)
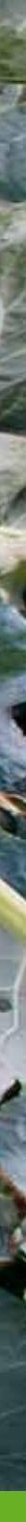

ing innovative concepts for sustainable agriculture in order to safeguard future food supplies. Food Chain Partnerships play a

key role in this context. The aim of these projects is to network key players along the value added chain - from producers to

on his fields and harvests them with the help of seasonal workers. Bayer employee Dinesh Balkrishna Bhoir (2nd from left) then

makes sure that the harvest reaches the end consumers. 


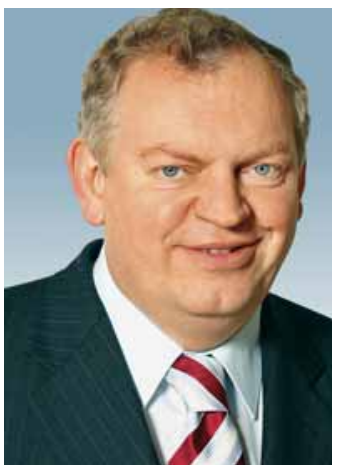

Dr. Franz-Josef Placke, member of the Executive Committee of Bayer CropScience

"We need a second green revolution in agriculture to sustainably master the challenges involved in safeguarding the world's food supply."

The challenges are great. While more than one billion people are already going hungry today, the demand for food and plant-based raw materials continues to rise. However, the amount of land available for growing crops is limited. Current forecasts published by the United Nations show that the amount of agricultural land available worldwide is likely to remain at approximately 1.5 billion hectares, which means that the amount available per person will diminish to just 0.16 hectares by 2050 . As a result, only 30 percent of the amount of arable land that was used for agricultural production in 1950 will be available per person in 2050 .

\section{Research for the future}

Bayer Cropscience is addressing these challenges with intensive research and development efforts. "Our goal is to increase the yields of numerous crops and improve their resistance and stress tolerance against environmental factors," explains Dr. Franz-Josef Placke, member of the Executive Committee and Head of the Development function at Bayer CropScience. "At the same time, we are working on boosting the quality of agricultural products, for example by extending shelf lives and improving taste properties and the quality of the fibers." To this end, Bayer CropScience is investing some $€ 650$ million yearly - equivalent to 10 percent of sales in 2009 - in conventional crop protection research (Crop Protection Business Unit) and the development of improved crops through modern breeding methods (BioScience Business Unit).
Bayer is thus actively supporting the United Nations' Millennium Development Goal of fighting hunger and poverty as well as providing a growing world population with sufficient quantities of high-quality food - an objective that all 191 participating countries at the 2009 World Food Summit in Rome reaffirmed in a pledge to the "human right to food."

\section{Partnerships with local producers}

This issue is not just about providing sufficient quantities of food, however; it is also about changing consumer habits, which are further stimulating the demand for fresh, affordable food products. Consumer quality awareness continues to grow, and increasing numbers of people are placing value on transparent and sustainable production conditions.

A food product undergoes numerous production, processing and quality control stages before it lands on the plate. Bayer CropScience is working together closely with food chain players such as growers, transporters, dealers and the processing industry to ensure that consumers can always count on first-class goods. Food Chain Partnerships exist in more than 40 countries, covering over 125 fruit and vegetable varieties. "By cooperating with all partners in the food chain, Bayer CropScience helps growers around the world supply the highest quality agricultural produce," explains Dr. Birgitt Walz-Tylla, Head of Food Chain Management at Bayer CropScience. "Through our range of modern and sustainable crop protection solutions, technical know-how and competent consulting services, we are able to offer producers and dealers high-quality goods for resale or processing. End consumers can ultimately look forward to a wide variety of healthy and tasty products all year long."

\section{Focusing on quality}

Since 2009, Bayer CropScience has been focusing on sustainable vegetable growing in India with a lighthouse project entitled "Food Chain Partnership Vegetables." One of the local growers is Yaseen Mohammed Shareef. "We are very pleased to have gained Bayer CropScience as a partner. The BCs experts assist us with sustainable cultivation; as a result, we now handle crop protection products much more prudently and use high-quality seed products. This in turn enables us to increase harvest yields and tap into new selling opportunities," he reports. Increasing crop yields also helps to prevent the expansion of agricultural land to nature or forest areas. The project currently comprises 80 units with a total area of 8,200 hectares; by 2011 Bayer expects to expand the program to 125 project units with a total area of 50,000 hectares - equivalent to about 70,000 soccer fields. 


\section{Objectives of Bayer's Sustainability Program}

\section{Lighthouse project "Food Chain Partnership Vegetables"}

- Work together with partners to jointly develop solutions for sustainable vegetable growing

- The objective is to help a total of 65,000 farmers grow vegetables on 50,000 hectares in 125 individual projects by 2011 .

- For the farmers, this means higher yields, better quality, larger-scale sales opportunities and an improved income.

\section{Lighthouse project "Direct Seeding of Rice"}

- Integrated program for sustainable rice-growing with a combination of new growing method involving directly seeding pregerminated rice with efficient use of pesticides and fertilizer

- Around 10 percent higher yield

- Approximately 30 percent reduction in water consumption and emissions of the greenhouse gas methane

To further stimulate demand for the products from the Food Chain Partnerships, Bayer CropScience signed a global cooperation agreement with Dutch-based company The Greenery in September 2009. The agreement with the international trading company, which specializes in the marketing of vegetables, fruit and mushrooms, complements the 30 existing Food Chain Partnership projects in Central and South America, Europe, Africa and Asia.

\section{Increasing competitiveness}

For the fifth time, Bayer CropScience exhibited at Fruit Logistica in Berlin, the world's biggest trade fair for the international fruit trade. At its stand at the fair, which took

\section{Strategic partnerships in Mexico}

Bayer CropScience has also implemented its internationally successful Food Chain Partnership concept in Mexico and entered into important alliances with leading certification agencies such as Mexico Calidad Suprema. Mexico is one of the biggest exporters of agricultural produce in the world. The country's most well known export goods include mangoes, melons,

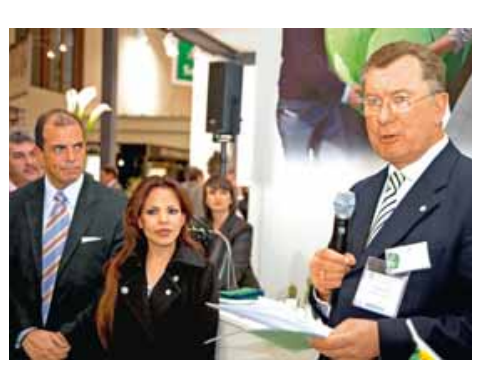

onions, cucumbers, tomatoes, citrus fruits, bananas, coffee and cocoa. This branch of the economy is one of the most important sources of national income.

At the Mexican reception at the Bayer CropScience stand at Fruit Logistica in Berlin (from left): Gabriel Padilla Maya (Mexican trade minister), Lizeth Quintero Posadas (Mexico Calidad Suprema) and Dr. Rüdiger Scheitza (member of the Board of Management of Bayer CropScience AG and Head of Global Portfolio Management) place from at the beginning of February 2010, the company's experts presented projects being conducted in more than 40 countries to facilitate the sustainable production of high-quality food. Bayer CropScience's integrated solutions based on innovative crop protection solutions and comprehensive advisory services play an important part in securing harvests and maintaining the quality of harvested produce. "In addition, we support fruit and vegetable growers in their efforts to market their goods internationally," says Walz-Tylla.

New cultivation methods and varieties for rice

Another Bayer lighthouse project focuses on rice, one of the most important food staples in the Asia/Pacific region. More than 40 million people subsist on rice in Indonesia alone. Bayer CropScience launched a program in this country in 2009 that aims to lastingly improve the yield and income situation of rice growers. The program is based on a new method of cultivation - direct seeding. Unlike the customary wet rice cultivation, by which growers set young plants in flooded paddies by hand, direct seeding involves the dry planting of pre-germinated rice by machine. This increases yields, saves enormous quantities of water, reduces the need for fertilizer and also lowers by 30 percent emissions of the greenhouse gas methane, which is produced through fermentation in stagnant water. The program comprises an integrated mix of seed, sowing machines, crop protection products and training courses for growers.

In the development of new rice varieties, Bayer CropScience also cooperates with the International Rice Research Institute (IRRI; see inset) in the Philippines. The Bayer researchers' goal is to increase rice yields by between 15 and 20 percent and make rice plants more resistant to environmental factors. Building on the IRRI's research results, Bayer CropScience is working on a variety of rice that can survive for up to 10 days under water without "drowning." This resistance is important in coastal regions that are subjected to repeated flooding - a situation that will likely become increasingly frequent as a result of climate change. 
Progress through innovation and partnerships Bayer's wide range of activities makes clear that the company will continue to focus intensively on the theme of nutrition in the coming years. The developmental pipeline for the Crop Protection Business Unit is well stocked: "Between 2010 and 2012 we plan to introduce six new crop protection active substances to the market. They will protect seeds against disease, weeds and pests. Some will also strengthen crops to enable them to better cope with weather- and soil-related stress situations," explains

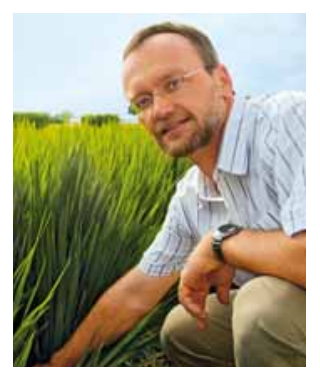

Dr. Achim Dobermann,

Deputy Director General for Research at the International Rice Research Institute (IRRI) in Manila, Philippines

Fruitful partnership for food safety

"Rice is the food staple for the world's less affluent populations. Since there is practically no space for additional growing areas, we have to work on increasing yields on existing acreages." This is how Dr. Achim Dobermann explains the most important task of the International Rice Research Institute (IRRI).

Bayer CropScience has been working together with the IRRI since April 2008 to breed new rice varieties and drive forward the development of ecologically sustainable rice production. Dobermann is optimistic about the future: "We have the potential to produce sufficient food in the world in an environmentally friendly manner. To achieve this, we need intensively managed agriculture: with modern technology that requires a low input of labor, water and energy. In most growing areas, we could harvest one to two tons more rice per hectare with better methods. This would provide enough rice for the next 15 to 20 years to keep pace with the growing world population." At the same time, Dobermann stresses, new high-yielding rice varieties are needed in the long term - including plants that can withstand higher temperatures, require less irrigation and are resistant to pests.

His assessment of Bayer's lighthouse project for direct rice seeding is positive: "Rice yields increase considerably with these newly developed cultivation methods. That is tremendously important - not just for Indonesia, but also for supplying rice to the entire world population."
Placke. In the area of bioscience, the company is currently concentrating on about 60 research projects in six different crops. Alongside the four traditional core crops cotton, canola, rice and vegetables, the BioScience Business Unit has expanded its research activities to include wheat and soybeans.

In 2009, Bayer CropScience further intensified its research activities by entering into more than 10 alliances with public and private research institutions, including the Commonwealth Scientific and Industrial Research Organisation (CSIRO) in Canberra, Australia. CSIRO is among the world's leading institutions in the development of new wheat varieties, which is a new research focus area for Bayer CropScience. The goal of this research alliance is to achieve higher yields, increased resistance and improved nutrient uptake by wheat crops.

In the context of international partnerships with institutes and organizations in China, Australia and the Netherlands, Bayer CropScience researchers achieved a key research breakthrough in 2009: they sequenced for the first time the entire genome of rapeseed (Brassica napus) and its constituent genomes present in field mustard (Brassica rapa) and wild cabbage (Brassica oleracea). This achievement will help Bayer CropScience to speed up its research and breeding programs, thus bringing new technologies and better products to growers much sooner. It will also enable research to be conducted into significantly more innovative ideas that will further improve the value of rapeseed as a crop. Rapeseed is the second largest oilseed crop after soybeans, accounting for approximately 15 percent of world production. 
The challenge

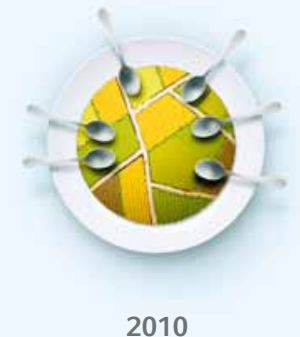

2010

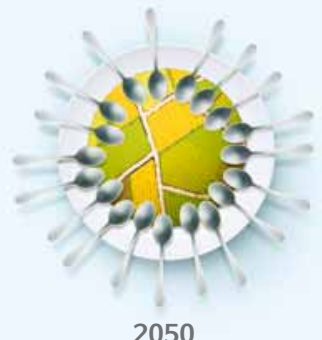

2050
Demand for food until 2050 will increase by $70 \%$ if the world's population grows from today's figure of 6.8 billion to 9.2 billion in 2050 as forecasted (source: UN) and in the face of changes in dietary habits and rising prosperity in populous emerging countries.

\section{The objective}

To provide humankind with sufficient high-quality, affordable food while using resources responsibly in the interests of sustainable agriculture

\section{Bayer CropScience's contribution to sustainable agriculture}

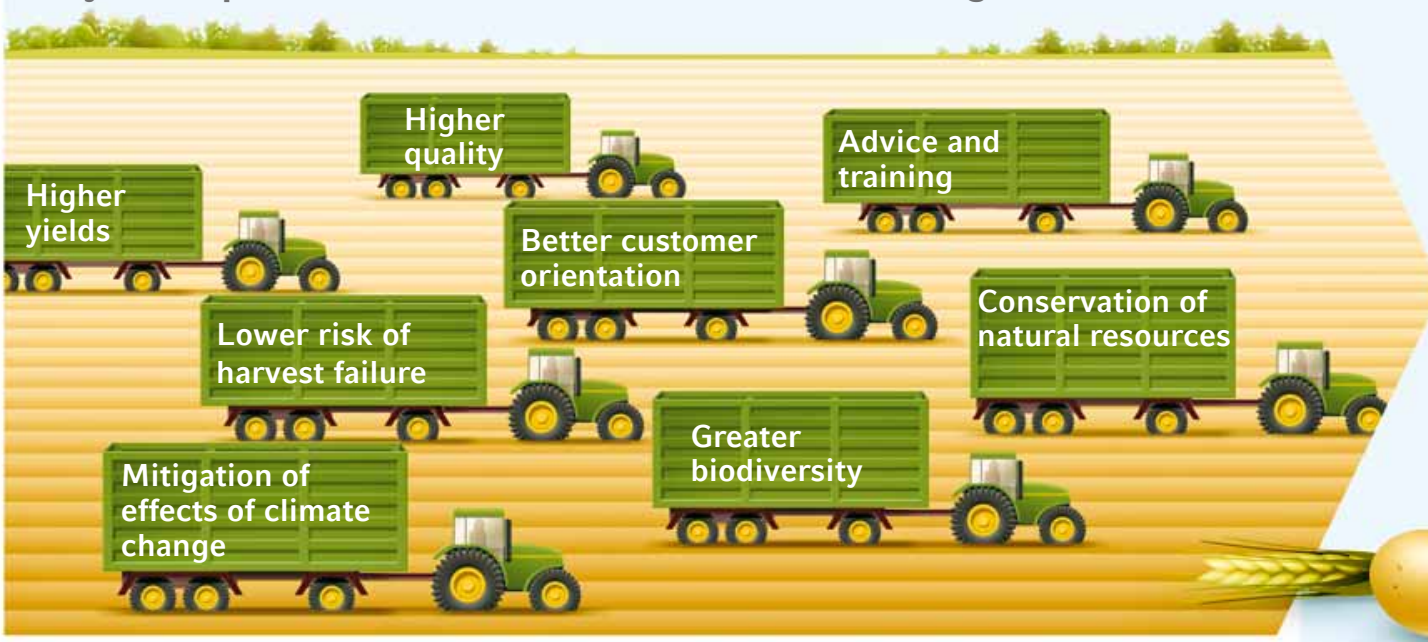

\section{The solutions}

Research and innovation are the key to mastering the agricultural challenge. Improving resource management and yields through innovative technologies forms the focus of the company's research into safeguarding and increasing harvests across a constant area of arable land.

The growing world population's rising demand for food stands in contrast to the increasing scarcity of arable land and natural resources (water, energy). Bayer CropScience has therefore aligned its research and development activities and its portfolio to sustainable agriculture. In doing so, Bayer CropScience is addressing all three cornerstones of sustainability - economy, ecology and society.

Through innovative products and services that are matched to the needs of farmers and the entire consumer chain, the company brings increased productivity into tune with the conservation of resources and the environment. To this end, Bayer CropScience is further expanding its business with crop protection agents, seeds and plant traits to meet the challenges of our time - from quality and profitability through to biodiversity and climate change.

WWW 30 un Millennium Development Goals | 31 World Summit on Food Security | 32 Food Chain Partnerships 33 The Greenery I 34 IRRI | 35 CSIRO 


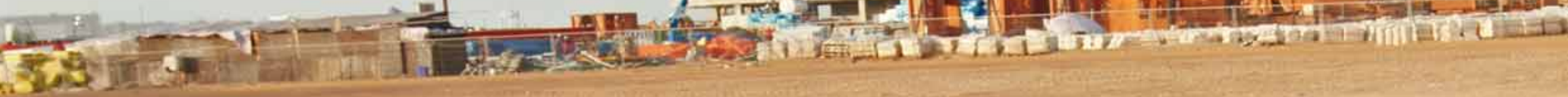

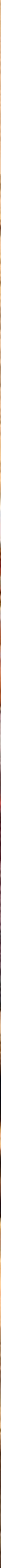




\section{Climate program takes effect}

Buildings account for a significant share of the world's greenhouse gas emissions.

Therefore, to achieve effective climate protection, there is a need for solutions

through which buildings can be constructed and operated in a more energy-efficient

way. This is an area in which Bayer has become one of the world's leading experts.

Other initiatives focus on increasing energy efficiency in production and dealing with the effects of climate change.

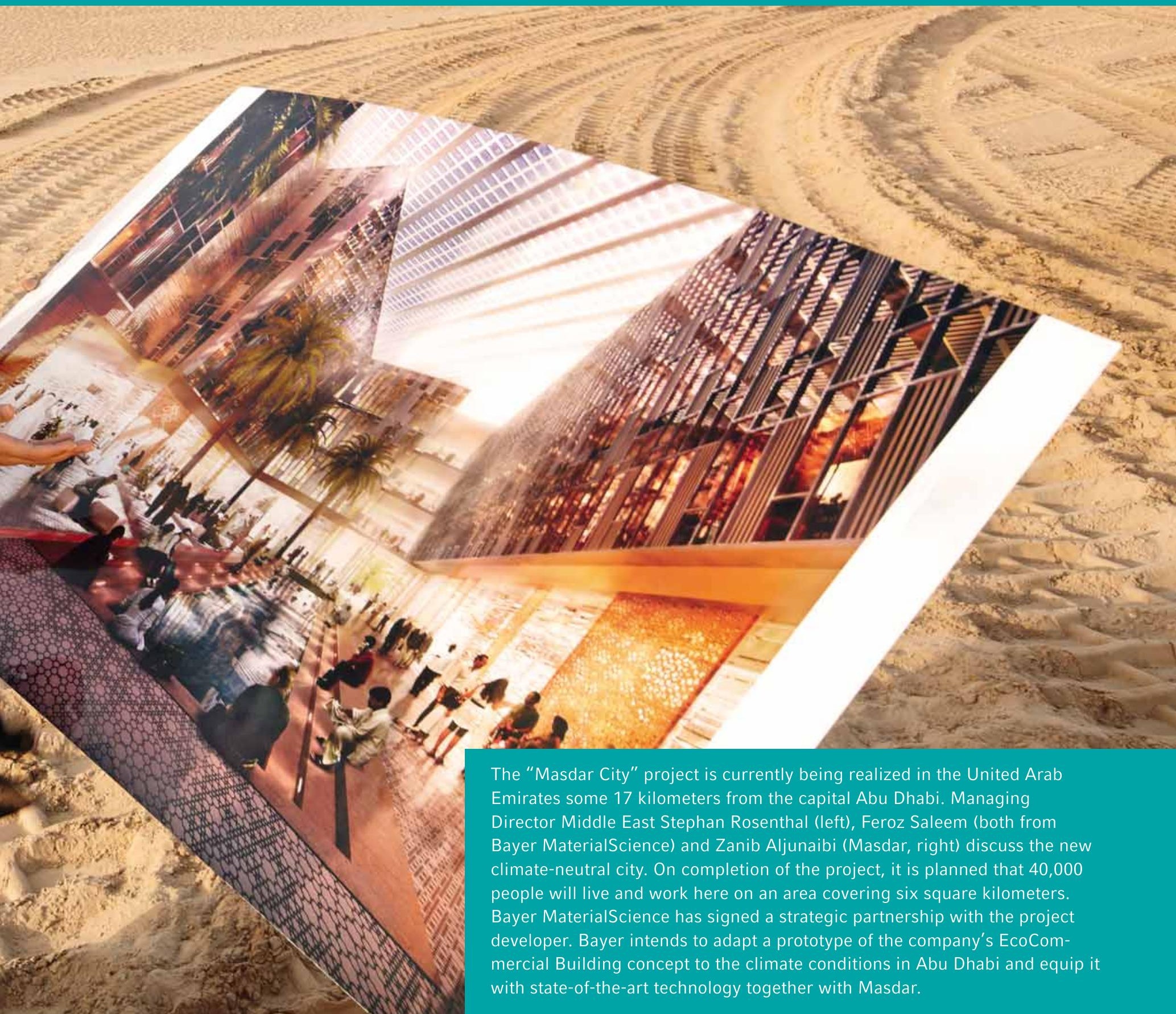


The Climate Program is one of three key focuses of the Bayer Sustainability Program. It trains the spotlight on solutions for climate protection. Our considerations and activities take in both our own energy use and production processes and solutions that support our customers in their climate protection efforts. Our lighthouse projects are playing a key role in this. These are initiatives that have an overriding significance for the entire Sustainability Program. The "Ecology" section (see page 92ff.) reports specifically on the progress Bayer has made towards achieving its climate objectives.

\section{Expanding the EcoCommercial Building program}

An important component of Bayer's climate initiative is the EcoCommercial Building (ECB) program. This involves the principle of bringing together the best materials, systems and technologies in order to construct an energy-optimized building to suit the climatic conditions at the site in question. At the heart of this is a comprehensive partnership network that brings together suppliers, building companies and architects. One of the partners is Bayer Technology Services, which contributes its expertise in sustainable construction to the ЕСв program. Since this is a worldwide proj-

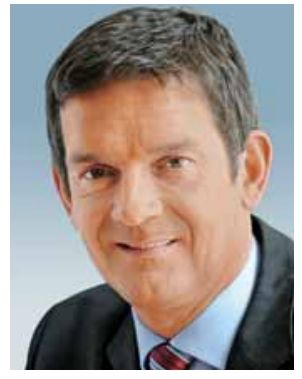

Dr. Wolfgang Grosse Entrup, Head of Environment \& Sustainability at Bayer AG

"The Copenhagen Accord issued after the Climate Conference in 2009 makes it clear that climate protection will only succeed if it goes hand in hand with economic development and sustainable growth. Ahead of the conference, Bayer stated plainly that its commitment to climate protection is geared towards long-term goals and that its efforts did not depend on the results of the negotiations." ect, ECB Centers of Excellence have been set up as points of contact in Europe, the Middle East and Africa, North America, China, Japan and Thailand.

While the EcoCommercial Building partnership project in Masdar is still at the planning stage, some of Bayer's own buildings constructed according to this concept are already in use. The first EcoCommercial Building (ECB) was opened in Germany in November 2009 - the Bayer CropScience children's daycare center in Monheim. This was honored with the award for "Energy-optimized building 2009" by the German Ministry of Economics. And an emissions-neutral office building, adapted to the climatic conditions of the subtropics, is currently being constructed in Greater Noida near New Delhi, India.

Another example of an energy-efficient building opened in Diegem, Belgium, in May 2009. This Bayer administrative center consumes around 40 percent less energy than comparable buildings and received the Belgian award for architecture and energy in 2009. And the zero-energy ECB Conference Center which opened at the company's site in Pittsburgh, United States, in May 2010 also demonstrates the range of eco-friendly applications that are possible using products from Bayer MaterialScience.

Alongside the new construction projects, there is also naturally provision for monitoring the energy efficiency of all existing Bayer real estate to identify potential and improve building operation.

Establishing climate protection as a core business "The EcoCommercial Building program is a good example of how Bayer is putting its climate protection strategy into practice," states Dr. Wolfgang Grosse Entrup, Head of Environment \& Sustainability at Bayer. According to him, it focuses on practical solutions that dovetail perfectly with the company's structure. "After all, our commitment will only be successful when climate protection is incorporated systematically into both our core business and our sustainability strategy."

This conviction is also reflected in the Copenhagen Accord, the political declaration of intent reached at the international Climate Summit in Copenhagen in 2009. Among the important priorities expressed is the stated intention to limit the rise in average global temperatures to a maximum of below two degrees Celsius above pre-industrial temperatures. In addition, climate protection is to be classified under the topic of sustainable development to ensure that ecological aspects are not separated from the issues of 


\title{
Objectives of Bayer's Sustainability Program
}

\author{
Lighthouse project "EcoCommercial Building Program"
}

- Focus on new large-scale commercial and public building projects; alignment to international core and growth markets

Lighthouse projects "Energy efficiency"

- Oxygen depolarized cathode (ODC) technology based on common salt: use of ODC technology at Bayer MaterialScience for industrial-scale chlorine manufacture; operational maturity of technology by 2013; reduction in electricity requirement of 30 to 50 percent compared with existing processes and thereby reduction in indirect $\mathrm{CO}_{2}$ emissions; first sale of ODC technology to third parties by 2015

- Establishment of StRUCTese $^{\circledast}$ energy management system to achieve sustainable and systematic reduction of $\mathrm{CO}_{2}$ emissions in energy-intensive plant

business development, economic growth and the struggle against poverty.

\section{Bayer Climate Check is a success}

As part of our climate protection activities, Bayer Technology Services has developed a new type of control tool which is aimed at energy-efficient and climate-friendly production. By mid-2010, around 140 production facilities and buildings will have been put under the microscope. Based on calculations for 126 plants, Bayer believes there is realistic potential for reducing both energy consumption and greenhouse gas emissions by approximately 10 percent through 2013 . This is a level that applies approximately to all regions in which Bayer has operations.

In parallel with the Climate Check, Bayer Technology Services has also developed a method for checking resource efficiency, which is to be applied in pilot projects in 2010 (see page 90).

Roll-out of the STRUCTese ${ }^{\circledR}$ energy management system Energy efficiency is also at the center of the new measurement and management method STRUCTеse ${ }^{\circledR}$ (Structured Efficiency System for Energy), which has been developed by Bayer MaterialScience in collaboration with Bayer Technology Services and Bayer Business Services. By the end of 2009, STRUCTese ${ }^{\circledR}$ had been successfully installed in 16 plants, enabling energy savings of more than $€ 10$ million to be sustainably realized and documented. The method is to be applied globally to 60 of the company's most energyintensive production facilities worldwide by 2012 .

Implementing climate-friendly processes worldwide The centerpiece of the particularly energy-efficient processes for the production of chlorine reported on in the Sustainable Development Report 2008 is the oxygen depolarized cathode technology. This enables hydrochloric acid to be recycled in chlorine production in an energyefficient way. Bayer researchers have now joined forces with partners as part of a project initiated by the BMBF (German Federal Ministry of Education and Research) with the goal of extending this technology to produce chlorine from common salt ( $\mathrm{NaCl}$ ). Bayer MaterialScience (BMS) has signed an agreement with the engineering company Uhde on the construction of a chlorine production facility based on this principle. For the first time, chlorine is to be produced on an industrial scale using oxygen depolarized cathode (ODC) technology from Bayer MaterialScience in electrolysis cells developed by UHDENORA. The plant, which will have an annual capacity of 20,000 metric tons, is scheduled to be taken into service in the first half of 2011.

At the end of October 2009, a Memorandum of Understanding was signed with the China Blue Star Group, one of the world's top four electrolysis cell manufacturers. Among its declarations, this Memorandum of Understanding states that Bayer will make its oxygen depolarized cathode technology available to the Chinese partner.

"China has always been an important growth market for Bayer. That's why it is important to us to support the spread of high standards for climate protection there," states HansJoachim Wittig, Head of ( $\mathrm{NaCl})$ ODC Technology at Bayer Material Science.

The modernization of waste air incineration at the site in Dormagen is an important milestone in Currenta's climate protection program, enabling the reduction of $\mathrm{CO}_{2}$ emissions by 30,000 metric tons a year.

Agriculture and health

Climate protection will play a bigger role in agriculture too in the future, according to the Copenhagen Accord. For example, Bayer CropScience has launched a lighthouse project for sustainable rice cultivation in Indonesia, where one of the goals is to reduce methane emissions by around 30 percent (see Focus Issue Nutrition on page 39). 
But in addition to implementing active measures for climate protection, responding to the effects of climate change is also an integral part of the Group-wide sustainability strategy. With this in mind, Bayer is working, for example, on increasing the yields and stress tolerance of crops, focusing in particular on state-of-the-art cultivation methods such as plant biotechnology. Researchers at Bayer CropScience are collaborating in international partnerships specifically to develop, among other crops, varieties of cotton and wheat that are resistant to drought.

Another important project is devoted to tackling malaria, because experts from the United Nations Environment Programme (UNEP) fear that climate change could cause the number of malaria sufferers to rise by between 40 and 60

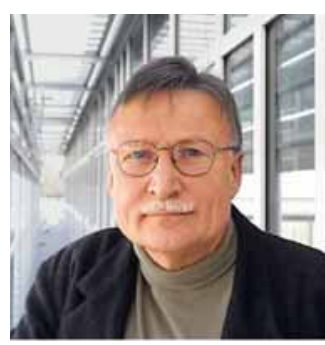

Professor Volker Hartkopf Professor of Architecture, Carnegie Mellon University, Pittsburgh, United States; Chair of Think Tank, Benchmarking of Best Practices, UNEP/SBCI (United Nations Environment Programme/Sustainable Building and Climate Initiative)

Worldwide, the operations of buildings account for up to 40 percent of $\mathrm{CO}_{2}$ emissions. In major urban centers, such as New York City, building operations account for 80 percent of emissions, though on a per capita basis, the city emits less than half the amount of greenhouse gas compared to the United States as a whole. Globally, urban populations are increasing rapidly. Currently, 50 percent of our population lives in cities. This figure is expected to increase to 70 percent by 2050 .

On numerous occasions, leading policy-makers have vowed to reduce carbon emissions by as much as 80 percent by 2050 . While intermittent steps are being taken, a holistic approach with verifiable attainments at credible intervals is largely missing.

The EcoCommercial Building program is of great significance in this context. This program will develop methodologies, approaches, associated guidelines and workbooks, as well as examples of solutions in different climatic and social economic contexts. This will provide measurable and verifiable data that can be credibly reported and thus help make it possible to successfully reach the necessary targets in both rehabilitation and new construction.

The Bayer Climate Program focuses on energy and resource efficiency regarding chemical processes, building materials and operations as well as agriculture. Valuable contributions to tackle climate change will result from this effort. million cases in Africa alone. The tropical disease could also spread to areas that were previously unaffected by malaria. Bayer CropScience has been working for many years with the World Health Organization (WHO) in the area of vector control. Now scientists at Bayer have developed a method of incorporating long-lasting active substances into the material of mosquito nets (see Focus Issue Health on page 34f.).

\section{Green IT, logistics and transport}

The "Green IT" initiative from Bayer Business Services focuses on energy-saving potential in IT and communication technology. The goal of this initiative is to improve the energy efficiency of Bayer's data centers in Leverkusen (Germany), Pittsburgh (United States) and Singapore by 20 percent between 2009 and 2012. These efforts are being supplemented by projects for cutting energy consumption and conserving resources at PC workstations and with centralized printers.

As another supporting measure under the Climate Program, Bayer is setting up telepresence rooms and optimized video conferencing systems to reduce the amount of travel necessary. So far, corresponding systems have been installed at the company's sites in São Paulo (Brazil), Raleigh, Pittsburgh (both United States), Leverkusen, Monheim (both Germany), Lyon (France) and Singapore.

Furthermore, by reconfiguring its fleet of vehicles worldwide, Bayer aims to cut corresponding $\mathrm{CO}_{2}$ emissions by 20 percent through 2012 compared to 2007 levels. Through the increased use worldwide of vehicles with consumptionoptimized engine technologies, a reduction of almost 10 percent in the average $\mathrm{CO}_{2}$ emissions per kilometer could be achieved in new registered vehicles procured compared to 2007. This initiative has received the International Green Fleet Award 2009 from Fleet Europe, the European specialist magazine for operators of international vehicle fleets.

Based on the slogan "Green Supply Chain \& Logistics," Bayer Technology Services is supporting the optimization of logistics processes. With the goal of bringing "all products under one roof," Bayer HealthCare has managed through this initiative to cut the number of warehouses worldwide and increasingly organize the transport of freight by railroads and waterways rather than by air.

\section{Cooperations and partnerships}

How cooperation in research and day-to-day business can lead to successful climate protection is illustrated by the "F ${ }^{3}$ Factory" (Flexible, Fast and Future Factory) research consortium headed by Bayer Technology Services. This is a project sponsored by the European Union where for the 


\section{Bayer Climate Fellowship - encouraging dedicated students}

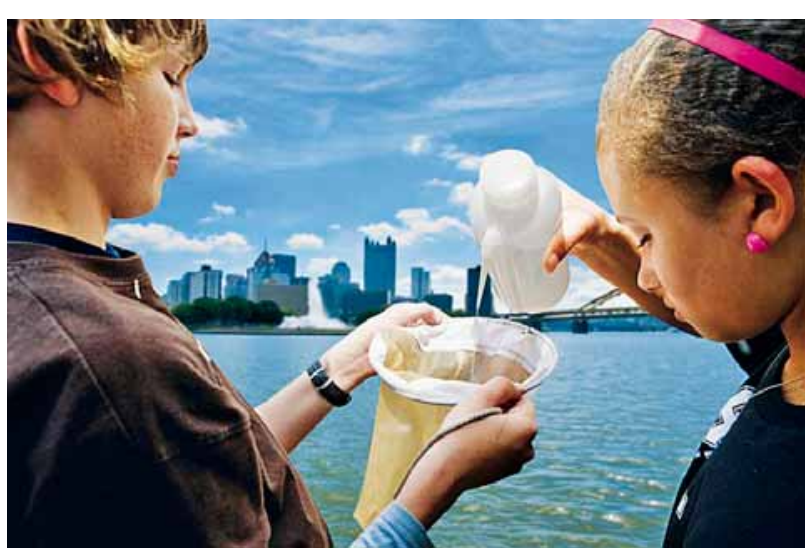

As part of the Bayer Climate Program, seven schoolchildren in Germany received scholarships from the Bayer Science \& Education Foundation to attend a two-week sustainability camp in Pittsburgh, United States, focusing on climate protection and sustainability. The camp was jointly organized by the Bayer USA Foundation and the environmental organization RiverQuest. The seven schoolchildren from Germany were joined by five children from the United States to focus on water as an ecosystem, the sustainable use of resources and the challenges posed by climate change. One scholarship student was also invited by Bayer to attend the Climate Summit in Copenhagen. first time 25 competing companies and research institutes have been collaborating on the development of efficient and sustainable manufacturing processes. These are to become accessible to the public in a new technology center at the CHEMPARK Leverkusen site to be completed by the beginning of 2011.

Bayer MaterialScience also cooperates closely with the United Nations Environment Programme (UNEP), in whose Sustainable Building and Climate Initiative $(\mathrm{SBCl})$ the company is intensively involved. Bayer MaterialScience supports the SBCI proposals for an internationally coherent and standardized method for measuring the climate footprint of buildings.

\section{Bayer Climate Award 2010}

Every two years, the Bayer Science \& Education Foundation presents the Bayer Climate Award in recognition of pioneering interdisciplinary research on climate change. The prize, which is worth $€ 50,000$, was awarded in 2010 to Professor Peter Lemke. His groundbreaking research on polar ice provided a key set of basic principles for climate sciences long before climate change became the focus of wider public awareness.

Lemke has worked at the Alfred Wegener Institute for Polar and Marine Research (AWI) in Bremerhaven since 2001, where he is currently Head of the Department of Climate Sciences. He is also Professor for Physics of Ocean and Atmosphere at Bremen University.

\section{Awards and prizes}

- Inclusion as the world's best company in the Carbon Disclosure Leadership Index for transparent reporting on climate strategy and greenhouse gas emissions

- China Environmental Excellence Prize in the category "Best Corporate Performance on Environmental Protection". This is the highest award handed out by the People's Republic of China for environmental protection.

- European Risk Management Award for the Climate Program in the "Best Environmental Initiative" category presented by the specialist magazine Strategic Risk

- International Green Fleet Award 2009 presented by Fleet Europe, the European specialist magazine for international operators of vehicle fleets, for the company's eco-friendly fleet management system as part of its Climate Program

WWW 36 Masdar | 37 ECB program | 38 Bayer Climate Program | 39 Copenhagen Accord | 40 UNEP | 41 WHO $42 \mathrm{~F}^{3}$ Factory | $43 \mathrm{SBCl}$ | 44 Bayer foundations | $\mathbf{4 5}$ RiverQuest | $\mathbf{4 6}$ Strategic Risk | $\mathbf{4 7}$ Carbon Disclosure Project 
$\oint$ TABLE OF CONTENTS

48 PERFORMANCE REPORT

Reporting principles
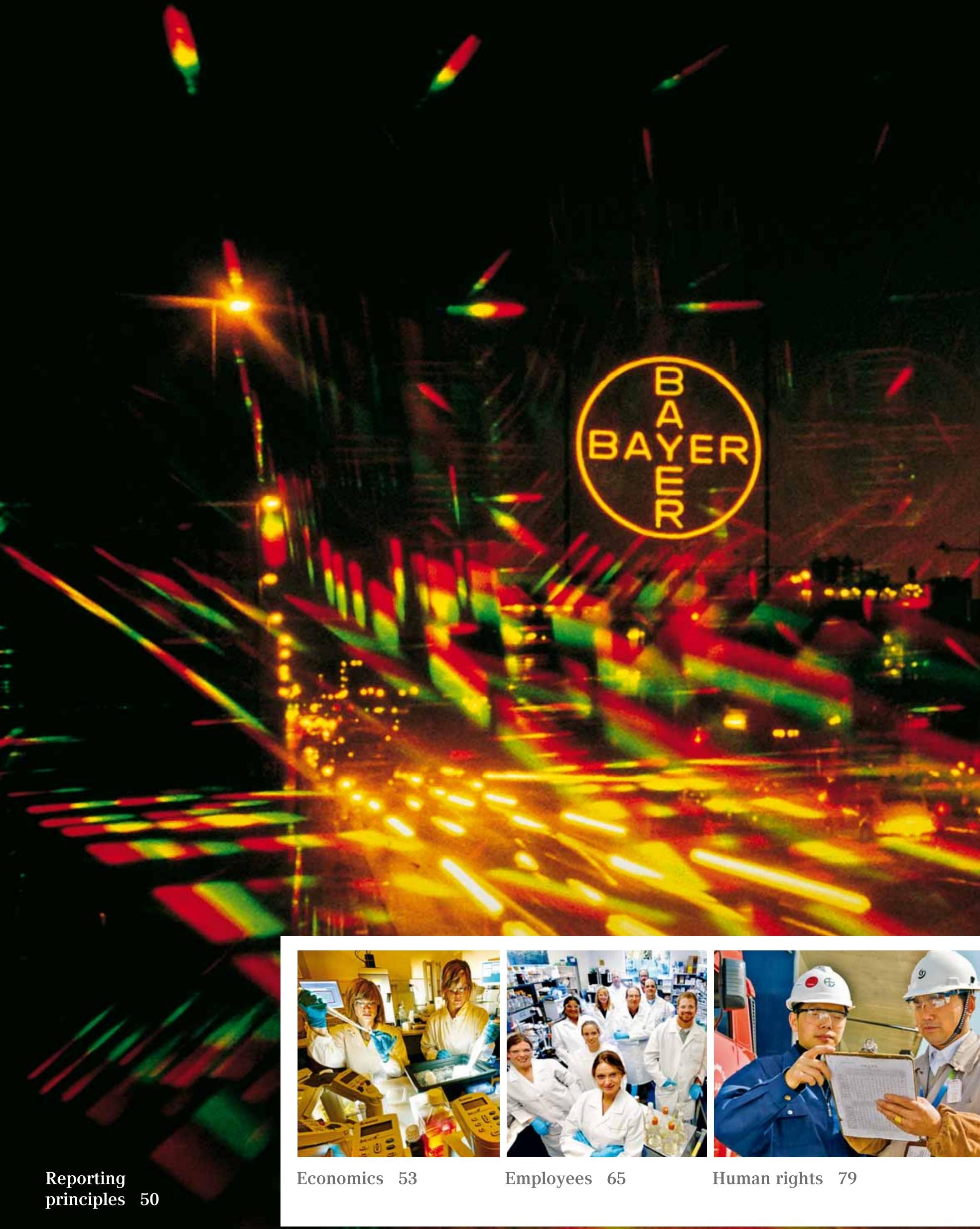

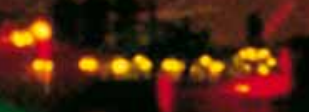

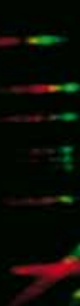




\section{Reporting principles}

Our Performance Report provides clear and concise information on all issues that we and our stakeholders consider to be of relevance for sustainability. It meets the requirements established in the current Global Reporting Initiative (GRI) guidelines and covers all internationally recognized financial and non-financial indicators corresponding to GRI level A+. You can find the full GRI index inside the back cover.

In 2006, for the first time, Bayer formulated specific five-year sustainability objectives to allow itself to measure its sustainability performance. The majority of the objectives will end their term in 2010. Meanwhile, in individual areas such as climate protection, we have already defined targets that go beyond those originally set. We shall take stock of the level of achievement of the 2006+ objectives in our Sustainable Development Report 2010 and also then publish new, focused Group objectives.

When selecting and measuring indicators, we took recommendations by the following into consideration:

- World Business Council for Sustainable Development (WBCSD)

- Greenhouse Gas Protocol (GHg Protocol)

- European Chemical Industry Council (Conseil Européen de l'Industrie Chimique, CEFIC) and

- Society of Investment Professionals in Germany (Deutsche Vereinigung für Finanzanalyse und Asset Management, DVFA) in conjunction with the European Federation of Financial Analysts Societies (EFFAS), for the reporting of non-financial indicators.

We also base our reporting on the content of the 10 principles of the UN Global Compact. Progress in the implementation of these principles is reported on an annual basis (cop - Communication on Progress, see inside the back cover).

\section{Recording sustainability indicators}

Transparent reporting is based on the acquisition of valid and plausible data. All HSE (health, safety and environment) performance indicators for the Group are summarized in BaySIS ${ }^{\circledR}$, our Group-wide, site-based information system. The data undergo plausibility checks and crosschecks to ensure a high level of data integrity. We use various other information systems to gather HR performance indicators and social data, such as ProKon, the Global HR Productive (GHP) system and the reporting database HRCT (Human Resources Controlling Tool).

We capture data from all of the relevant organizational units and companies worldwide which fall within the scope of the Bayer Group's consolidated financial statements. Our health, safety and environment (HSE) data cover all companies in which we have a holding of at least 50 percent. The key performance data of these companies have been fully consolidated, regardless of Bayer's precise share in the respective company. The years 2005 to 2009 reflect the continuing business operations without the divested Wolff Walsrode, H.c. Starck and Diagnostics sites. Schering sites have been included in the figures from the date of acquisition, June 23, 2006.

We present our greenhouse gas emissions from 2005, the baseline year for the climate targets up to 2020 set in the Bayer Climate Program. Greenhouse gases are presented on a portfolioadjusted basis in accordance with the financial control approach of the GHG Protocol. 
The data capture process and the statements made in the focus issue sections and throughout the Performance Report have been reviewed by the auditing company Ernst \& Young to verify that they are consistent, appropriate and plausible (see page 113f.). Furthermore, on-site visits were made to 10 reporting objects in Germany, Switzerland, China, Japan and Mexico. During these visits, random checks were made on the gathering and reporting of HSE data.

\section{Interpreting performance indicators}

Our Performance Report provides a clear depiction of the development in our sustainability performance indicators. In order to rank the performance indicators, it is important in the case of many of the parameters to present the values in relation to the annual production volume. The volume of products sold fell by 1.3 million metric tons during the reporting year to 8.7 million metric tons (for further details see the "Ecology" section on page 86).

\begin{tabular}{lrrrrr}
\hline Volume of products sold & 2005 & 2006 & 2007 & $\mathbf{2 0 0 8}$ & $\mathbf{2 0 0 9}$ \\
\hline $\begin{array}{l}\text { Volume of products sold } \\
\text { (million metric tons) }\end{array}$ & 9.7 & 10.1 & 10.6 & 10.0 & 8.7 \\
\hline $\begin{array}{l}\text { Change compared with the previous } \\
\text { year (percent) }\end{array}$ & +6.6 & +4.1 & +5.0 & -5.7 & -13.3 \\
\hline
\end{tabular}

\section{Management systems for attaining company-wide HSEQ objectives}

Bayer's goal is to achieve an appropriate and uniform level of performance in the areas of health, safety, environment and quality (HSEQ) throughout the Bayer Group worldwide, and to make continuous improvements. In order to attain this goal, Bayer has established corresponding HSEQ management systems in all subgroups and service companies. These systems are based on international standards and are regularly reviewed and updated.

At the end of 2009, Bayer CropScience completed the auditing of relevant sites in accordance with the HSEQ core requirements. The subgroup also reviewed all 36 production sites with regard to process and plant safety between 2007 and 2009.

Bayer HealthCare is also optimizing and auditing its HSEQ management systems on a continuous basis in accordance with an annually specified, risk-based program. In 2009, the subgroup enacted seven new HSE directives.

The Bayer MaterialScience (BMS) Integrated Management System is monitored continuously as part of a global internal HSEQ auditing program and is externally certified to ISO 9001.

In all, 87 percent of our production sites had a Bayer-audited HSE management system in 2009.

\section{7 percent}

87 percent of our production sites have a Bayer-audited HSE management system. 


\section{International standards and certifications}

Around 40 percent of our production sites have been externally certified according to internationally recognized regulations such as the environmental management standard ISo 14001 or validated according to the European environmental management regulation EMAS (Eco-Management and Audit Scheme).

All subgroups and service companies have quality management systems. Because quality requirements and standards are commonly defined on an industry-specific level, their implementation lies within the responsibility of our subgroups and service companies.

In order to support our goal of further reducing the occupational injury rate, further sites underwent certification during the reporting year in accordance with oHSAS (Occupational Health and Safety Assessment Series) 18001, an international standard focused primarily on prevention.

Due to an overall reduction in the number of certified production sites (e.g. due to sales or closures) and the expiry of various certificates at some sites, we have observed a downward trend in the percentage of our sites that are certified. As part of our company objectives, we will strive in the coming years to increase this percentage once again.

\begin{tabular}{lcccccc}
\hline $\begin{array}{l}\text { Certifications and audits (as a percentage of the total number of Bayer production sites) } \\
\end{array}$ 2005 & 2006 & 2007 & 2008 & 2009 \\
\hline $\begin{array}{l}\text { Sites with a management system certified } \\
\text { to ISO 14001 or validated to EMAS }\end{array}$ & 36 & 36 & 33 & 34 & 31 \\
\hline $\begin{array}{l}\text { Sites with an HSE management system } \\
\text { based on other external standards * }\end{array}$ & 4 & 7 & 10 & 21 & 14 \\
\hline $\begin{array}{l}\text { Sites with a management system } \\
\text { certified to OHSAS 18001 }\end{array}$ & 5 & 8 & 8 & 8 & 15 \\
\hline $\begin{array}{l}\text { Sites with a Bayer-audited HSE } \\
\text { management system }\end{array}$ & - & 62 & 64 & 77 & 87 \\
\hline
\end{tabular}

* e.g. RCMS (Responsible Care Management System) in the United States or Industria Limpia (clean industry) in Mexico

WWW 48 GRI | 49 WBCSD | 50 GHG Protocol | 51 CEFIC | 52 DVFA | 53 EFFAS 54 UN Global Compact | 55 BaySIS | 56 Certifications and memberships 


\section{Economics}

Innovations play a key role in developing future-oriented solutions to tackle global challenges. We aim to achieve a lasting increase in company value through continuous R\&D and customer-oriented products and services in our core areas of competence: nutrition, health care and high-tech materials.

\section{9 operationally one of Bayer's strongest years}

Bayer was successful in 2009 in difficult circumstances: earnings before interest, taxes, depreciation and amortization (EBITDA) before special items came in at $€ 6.5$ billion, the third-highest level in our history. However, that was 6.6 percent lower than in 2008. The operating result (ЕВIT) was diminished by a number of special items totaling $€ 766$ million. These chiefly related to the integration of Schering, restructuring and litigation.

Group sales declined in 2009 by 5.3 percent to €31.2 billion. As expected, sales trends differed in the three subgroups. HealthCare lifted its sales by 3.8 percent in nominal terms to almost $€ 16.0$ billion. CropScience gained market share and grew sales by 2.0 percent to $€ 6.51$ billion. MaterialScience was severely impacted by the global financial and economic crisis, and sales declined 22.8 percent to $€ 7.5$ billion.

Stockholders benefited from last year's robust overall business performance. Bayer paid an unchanged dividend of $€ 1.40$ per share, giving a payout ratio of 38.5 percent of core earnings per share.

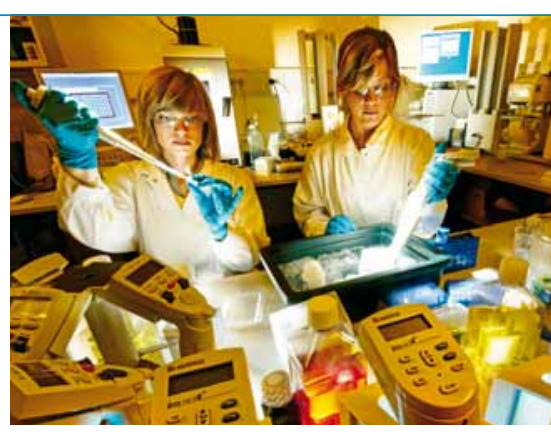

Innovations are absolutely essential for Bayer's future. That's why we invested almost $€ 2.8$ billion in research and development in 2009. Linda Sarah Hoffmann and Sandra Geschka (from left) prepare test series for a new active substance in the Pharmaceutical Research Department at the Elberfeld site.

\section{In focus}

Continued high spending on R\&D

- Generating growth through sustainable innovations

- Protecting our intellectual property

Actively fostering lawful and responsible conduct

Safeguarding the value of the company through effective risk management 
Key financial data for the Bayer Group * (€ million or percent)

\begin{tabular}{lrrrrr} 
& 2005 & 2006 & 2007 & 2008 & \multicolumn{1}{c}{2009} \\
\hline Net sales & 24,701 & 28,956 & 32,385 & 32,918 & 31,168 \\
\hline Sales outside Germany & $84.4 \%$ & $84.4 \%$ & $85.1 \%$ & $85.4 \%$ & $86.7 \%$ \\
\hline Income before income taxes & 1,912 & 1,980 & 2,234 & 2,356 & 1,870 \\
\hline $\begin{array}{l}\text { Income from continuing } \\
\text { operations after taxes }\end{array}$ & 1,374 & 1,526 & 2,306 & 1,720 & 1,359 \\
\hline $\begin{array}{l}\text { Income from discontinued } \\
\text { operations after taxes }\end{array}$ & 221 & 169 & 2,410 & 4 & - \\
\hline Income after taxes & 1,595 & 1,695 & 4,716 & 1,724 & 1,359 \\
\hline Return on equity & $14.4 \%$ & $14.1 \%$ & $31.8 \%$ & $10.4 \%$ & $7.7 \%$ \\
\hline Net financial debt (total) & 5,494 & 17,539 & 12,184 & 14,152 & 9,691 \\
\hline Income taxes & -538 & -454 & 72 & -636 & -511 \\
\hline
\end{tabular}

* Figures for 2005-2008 as last reported

Further key data can be found inside the front cover and in the Annual Report 2009.

\section{Research and development}

As an inventor company, Bayer stands for research and development. Innovation is vital for the future of the company. With this in mind, we maintained our commitment to research and innovation despite the economically challenging environment. In 2009, we invested €2.75 billion in research and development (R\&D), more than ever before, and more than any other company in the German chemical and pharmaceutical industry. Our R\&D budget was 3.5 percent higher than in the previous year and amounted to 8.8 percent of sales.

Research has always been a driving force of the Bayer Group and we will strive to continue our high level of research in the future. Our R\&D budget is expected to total some €2.9 billion in 2010. Further details of the global R\&D activities of our subgroups can be found on page $100 \mathrm{ff}$. of the Annual Report 2009.

We currently have some 12,400 people employed in R\&D. Their work is supplemented by an international network of leading universities, public research institutes and partner companies.

Our open innovation approach to research plays an increasingly important role. Projects are undertaken in collaboration with a range of partners from all stages in the value-added chain. Such research alliances are supported by public funding, thus facilitating the entrepreneurial decision to invest in risky development projects. Overall, Bayer was involved in 80 research alliances in Europe in 2009, for which it received public funding amounting to €12 million. For example, Germany's Federal Ministry of Education and Research supports the commitment of Bayer MaterialScience and Bayer Technology Services to the innovation alliance Carbon Nanotubes Inno.cNT (http://www.innocnt.de/en/). This initiative brings together more than 80 highly specialized small and mid-sized companies, large industrial corporations, scientific institutions and a large number of universities. The objective is to support the development and use of carbon nanotubes (CNT). Findings from 2009 pave the way to raise the energy efficiency of many products. 
Research and development costs* (€ million)

\begin{tabular}{lrrrrr} 
& 2005 & 2006 & 2007 & 2008 & 2009 \\
\hline Total & 1,729 & 2,297 & 2,578 & 2,653 & 2,746 \\
\hline of which BHC & 834 & 1,426 & 1,700 & 1,742 & 1,847 \\
\hline of which BCS & 664 & 614 & 637 & 649 & 653 \\
\hline of which BMS ** & 214 & 227 & 209 & 221 & 207 \\
\hline of which reconciliation *** & 17 & 30 & 32 & 41 & 39 \\
\hline
\end{tabular}

* Figures for 2005-2008 as last reported

** Excluding R\&D undertaken jointly with customers

*** Not directly allocated, mainly expenditures of the service companies

\section{Protecting intellectual property}

Reliable global protection of intellectual property is essential for an inventor company like Bayer because intellectual property is vital for innovation. Without effective global patent protection, companies like Bayer would have no way of recouping the substantial amounts they spend on research into new solutions. This would eliminate the commercial incentive and funding for further innovation. Patented products and technologies account for around 40 percent of the sales generated by each of our three subgroups. We therefore vigorously defend our intellectual property.

Since the end of 2008, Bayer has been engaged in a dispute with the Drug Controller General of India (DCGI), which processed a registration application submitted by an Indian company for a generic version of our cancer drug Nexavar ${ }^{\circledR}$ despite valid patent protection because, unlike Europe and the United States, India does not recognize protection of registration documents. Before expiry of the patent, Bayer would have to take out a court injunction against every single distributor to prevent marketing of this me-too product even though it infringes patent protection. That would be extremely expensive and time-consuming. And we could make better use of those resources.

\section{Innovation in our areas of expertise}

Innovations are essential for the future of our company. Indeed, since innovative products and services are the key drivers of sustainable growth at an inventor company, they are at the heart of our corporate and sustainability strategy. Focused development of new products that strengthen our core businesses is particularly important. We therefore strive for constant renewal and expansion of our product portfolio and endeavor to optimize our production processes. Since our research and development activities are closely aligned to market needs, they are subject to a continuous process of adjustment. Our subgroups and service companies contribute their specific know-how and utilize synergies, for example in interface technologies such as nanotechnology and biotechnology. Areas of innovation that are not central to the subgroups' areas of business are developed by Bayer Innovation $\mathrm{GmbH}$ in cooperation with the subgroups and external partners such as universities, start-up initiatives or other companies.

Patent protection

Patented products and technologies make up 40 percent of our sales. 
We aim to create a dynamic and sustainable culture of innovation that is based on our strengths in research and development and is constantly enriched by new ideas. Triple-i - Inspiration,

\section{Personalized vaccines from tobacco plants}

The approval of a Phase I study on a personalized vaccine by the FDA (Food \& Drug Administration) in the United States is a milestone for Bayer Innovation $\mathrm{GmbH}$. This vaccine, the first to be obtained from tobacco plants using magnicon ${ }^{\circledR}$ technology, is now being tested in human subjects in the United States. The patient-specific vaccines are intended for the treatment of non-Hodgkin's lymphoma (NHL), a type of cancer affecting lymphocytes. The objective of the new therapy is to activate the patient's immune system, enabling the malignant cells to be targeted and destroyed by the body's own defense system.

magnicon ${ }^{\circledR}$ technology is a new process for the rapid production of high yields of proteins such as biopharmaceuticals in tobacco plants. The plant is not genetically modified: the blueprint for the required product is merely inserted into it temporarily using a species of Agrobacterium. The protein is subsequently extracted from the plant's leaves in a very pure form. The process can also be carried out in a large-scale closed facility.
Ideas, Innovation - was introduced in 2006 to encourage Bayer employees worldwide to submit ideas for possible new products and thereby help to strengthen the company's innovative capability. So far, more than 10,000 suggestions have been submitted and the first products have already been commercialized. In 2009, Triple-i had a threefold focus: a drive to find ideas to improve marketing of the Supradyn nutritional supplement, the "Womanology" campaign for new women's health products and services, naturally including the areas of contraception, pregnancy and gynecological therapies, and a Triple-i China campaign.

\section{Examples of sustainable innovations by Bayer's subgroups and service companies in 2009}

\begin{tabular}{|c|c|}
\hline Product & Explanation \\
\hline \multicolumn{2}{|l|}{ Bayer HealthCare } \\
\hline $\begin{array}{l}\text { Decentralized drug approval } \\
\text { procedure for Visanne }{ }^{\circledR} \text { for the } \\
\text { treatment of endometriosis in } \\
\text { Europe completed }\end{array}$ & $\begin{array}{l}\text { This product for the treatment of chronic endometriosis } \\
\text { (painful proliferation of the lining of the uterus) will be } \\
\text { launched in Europe from mid-2010. }\end{array}$ \\
\hline $\begin{array}{l}\text { CONTOUR }{ }^{\circledR} \text { USB } \\
\text { New blood glucose meter }\end{array}$ & $\begin{array}{l}\text { This new blood glucose meter based on plug- } \varepsilon-\text { play } \\
\text { diabetes management software is geared to the individual } \\
\text { needs of diabetics. }\end{array}$ \\
\hline $\begin{array}{l}\text { BETAPLUS }^{\circledR} \text { program and } \\
\text { innovative application system }\end{array}$ & $\begin{array}{l}\text { Successful treatment of multiple sclerosis will be } \\
\text { supported by an extensive patient care program and } \\
\text { a progressive injection system that makes injections } \\
\text { more comfortable and less painful for the patient. }\end{array}$ \\
\hline \multicolumn{2}{|l|}{ Bayer CropScience } \\
\hline $\begin{array}{l}\text { Routine }{ }^{\circledR} \text { stimulates the immune } \\
\text { system of rice plants to resist rice } \\
\text { blast and thus prevents harvest } \\
\text { losses. }\end{array}$ & $\begin{array}{l}\text { Isotianil is a new systemic active substance. It has no } \\
\text { direct fungicidal effect but activates the immune system in } \\
\text { rice plants. Market launch in the main Asian rice-growing } \\
\text { countries started in } 2009 \text {. }\end{array}$ \\
\hline $\begin{array}{l}\text { Introduction of new, higher- } \\
\text { yielding cotton varieties with a } \\
\text { less active stress gene }\end{array}$ & $\begin{array}{l}\text { Cotton varieties in which the activity of a stress-induced } \\
\text { gene (PARP gene) is reduced yield up to } 10 \text { percent more } \\
\text { cotton fiber in field tests in both optimal and sub-optimal } \\
\text { conditions. The technology used to control the stress } \\
\text { gene is RNA interference (RNAi), which is widely used in } \\
\text { medical research. }\end{array}$ \\
\hline
\end{tabular}




\begin{tabular}{|l|l}
\hline Product & Explanation
\end{tabular}

\section{Bayer MaterialScience}

Dream production: pilot plant for effective, environmentally compatible utilization of $\mathrm{CO}_{2}$

Construction of a state-of-theart, world-scale facility for the polyurethane raw material toluene diisocyanate (TDI) at the integrated production site in Shanghai

Joining forces for climate protection: Bayer MaterialScience and SBM Offshore are developing technology for wave energy farms.

\section{Bayer Technology Services}

BAYQIK $^{\circledR}$ (quasi isothermal catalysis) process for the production of sulfuric acid

\section{Bayer Business Services}

E-learning tool to train employees in the new Globally Harmonized System of Classification and Labeling of Chemicals (GHS)
This project developed by BMS, Bayer Technology Services, RWTH Aachen University and other partners chemically bonds $\mathrm{CO}_{2}$, which is used as a component in polyether polyols. The project is financed by the German Ministry for Education and Research (BMBF).

Mechanical construction work is scheduled for completion in 2010 and the plant is expected to start operating in 2011. The Chinese authorities have issued an initial operating permit for 250,000 metric tons p.a. The company's global TDI capacity will thus increase to over 700,000 metric tons p.a.

This technology aims to generate eco-friendly energy in the future by harnessing the untapped resources of the sea. The World Energy Council estimates that global wave energy resources are roughly double current global consumption of electricity.

\begin{tabular}{|c|c|}
\hline ( & and provides training. \\
\hline \multicolumn{2}{|l|}{ Currenta } \\
\hline $\begin{array}{l}\text { Water tower: innovative } \\
\text { energy optimization concept in } \\
\text { Dormagen }\end{array}$ & $\begin{array}{l}\text { Currenta has significantly reduced the energy required } \\
\text { to pump process water, by } 15 \text { percent. That corresponds } \\
\text { to around } 4,800 \text { Megawatt hours (MWh) a year. This has } \\
\text { been achieved through energy-optimized operation cou- } \\
\text { pled with a change in line integration of the water tower } \\
\text { to regulate pressure (for more information see page } 89 \text { ). }\end{array}$ \\
\hline
\end{tabular}




\section{Our regional commitment}

As an international company, Bayer supports economic and social development in many parts of the world. As an employer, fair remuneration and pension and health care plans improve the social security of employees at our sites and strengthen local purchasing power. In 2009, our personnel expenses and expenses for pension plans and pension obligations amounted to $€ 23,707$ million. We also make a contribution to the common good through our tax payments.

\begin{tabular}{lccccc}
\multicolumn{7}{l}{ Personnel expenses and pension obligations* (worldwide, $€$ million) } \\
& 2005 & 2006** & 2007 & 2008 & 2009 \\
\hline Personnel expenses & 5,318 & 6,630 & 7,571 & 7,491 & 7,776 \\
\hline $\begin{array}{l}\text { - of which pension and social } \\
\text { security contributions }\end{array}$ & 1,009 & 1,414 & 1,611 & 1,513 & 1,490 \\
\hline Pension obligations*** & 15,561 & 16,708 & 15,022 & 14,910 & 15,931 \\
\hline
\end{tabular}

* Figures for 2005-2008 as last reported

** The 2006 figures only contain Schering from June 23, 2006.

*** Present value of defined-benefit obligations for pensions and other post-employment benefits

Our procurement volumes are also a significant factor in the development of many regions. Bayer sources goods and services totaling some €13.7 billion from around 87,000 suppliers in around 100 countries. Roughly 14 percent of the total is for purchases made in non-OECD countries.

\section{Suppliers and procurement expenses according to economic region}

\begin{tabular}{lcc} 
& Suppliers (percent) & Spending (percent) \\
\hline $\begin{array}{l}\text { Non-OECD countries } \\
\text { (approx. 70\% of all countries) }\end{array}$ & 26 & 14 \\
\hline $\begin{array}{l}\text { OECD countries } \\
\text { (approx. 30\% of all countries) }\end{array}$ & 72 & 84 \\
\hline N/A* & 2 & 2 \\
\hline Total & 100 & 100 \\
\hline
\end{tabular}

* Master data not harmonized due to ongoing system integration

We actively support local development in many parts of the world. For example, Bayer CropScience facilitates direct market access for farmers in 15 villages in the Indian state of Karnataka in collaboration with the Indian commodity futures exchange and the Indian post office, thus cutting out middlemen. An employee funded by this project provides the farmers, many of whom cannot read and write, with information from specialized websites such as those operated by the commodities exchange. Post offices, which all have computers, are used to distribute information to the farmers, for example on current market prices for crops. This gives farmers better access to the market, enabling them to sell their crops where they obtain the highest prices, so a higher proportion of value-added remains in their villages. 
At our CHEMPARK site in Dormagen, Germany, we are planning to invest €150 million in the construction of a new high-tech production facility for toluene diisocyanate (TDI). Capacity will be 300,000 metric tons p.a. and the facility will replace the present plants in Dormagen and Brunsbüttel. The new facility will be based on innovative, patented TDI process technology that cuts energy requirements by up to 60 percent and uses 80 percent less solvent.

The area occupied by the CHEMPARK sites in Leverkusen, Dormagen and Krefeld-Uerdingen in Germany totals some $11 \mathrm{~km}^{2}$. More than 70 manufacturing, research and service companies operate from these three CHEMPARK sites. Over 45,000 people work at these locations, which are responsible for one-third of chemical production in the German state of North Rhine-Westphalia. Securing the ongoing development of these sites by attracting new companies is one of the main tasks of Currenta, which manages and operates CHEMPARK. A partnership agreement has now been signed with Nanjing Chemical Industry Park, one of the three largest chemical and industrial parks in China. The aim is to share information and experience and step up site marketing. This is the world's first cooperation between two chemical parks.

\section{A global commitment to compliance}

Lawful and responsible conduct is mandatory for all employees in the Bayer Group and we do not tolerate infringements of the law. This is set out in our Corporate Compliance Policy, which contains a strict ban on corruption and anti-competitive practices. It specifically fosters the creation and safeguarding of fair and respectful working conditions and contains a clear commitment to respect intellectual property rights. It also forms the basis for our sustainability principles. Corporate Auditing reviews the effectiveness of the Corporate Compliance Policy at regular intervals on behalf of the Group Compliance Committee.

The Corporate Compliance Policy brochure is available in 38 languages and compliance information is published in the intranet Group-wide in German, English, French and Spanish. Here, employees can also find details of how to contact compliance officers, together with the phone numbers of local compliance hotlines, which are organized either nationally or regionally. In countries where we have not been able to set up a local compliance hotline for legal or organizational reasons, this function is fulfilled by ombudsmen or compliance officers.

A web-based training program, "Corporate Compliance Basics," has been developed to accompany the Corporate Compliance Policy, which was updated at the end of 2008. The first group of around 900 employees from two of our German companies has already completed this training program and roll-out within the Group will continue in 2010. In parallel with this, we will be continuing our Group-wide employee training sessions on compliance to bring the importance of the issue home to employees. 
Every Bayer employee is required to report any violation of this policy. The only exception is in France, where this reporting requirement is not applicable due to the nature of national law. In the event of proven violation of the compliance policy, the consequences range from a reprimand to dismissal, and may also include changes in business processes. In 2009, our global compliance hotline and e-mail address registered 57 reports -27 from Germany and 30 from other countries. 43 of these were received by e-mail, including 19 anonymously, and 14 were phone calls, 11 of which were anonymous. All reports were investigated by the responsible compliance officers. In most cases where the investigations have been completed, no infringement of compliance principles has been found.

In Germany, each subgroup and service company has a compliance committee and there is at least one compliance officer and often a local compliance committee in every country where we operate. In April 2009, a new Group Directive on Compliance Organization came into effect. This sets out the clear and binding responsibilities of the compliance officers, defines reporting lines and integrates the established hotline system. In connection with this new regulation, in 2009 we introduced a standardized training concept for our compliance officers, covering the responsibilities associated with this function, and held our first Compliance Officer Training Workshop in September. The workshops, which also aim to foster networking between compliance officers and the creation of a Group-wide compliance community, will be continued in 2010.

Compliance officers are also expected to become more involved in verifying and approving payment instructions. To support this, we issued a procedure on verifying payment transactions in 2009. Payments to external parties are checked by the accounting departments from a range of viewpoints. In cases of doubt, the matter should be passed on to the responsible compliance officer, who will then decide whether to approve or halt the payment.

In 2010, we plan to introduce a global database where local compliance officers will be required to enter compliance issues that are drawn to their attention and investigated. In parallel with the introduction of this tool, a Group-wide regulation will be issued defining how to conduct investigations when suspected infringements of compliance rules are reported.

To anchor compliance even more firmly at senior management level, an initiative to integrate compliance into performance management for Group executives (members of the Group Leadership Circle) was introduced in 2009. From 2010, a compliance target will be included in the performance objectives agreed with every executive and taken into account in their annual appraisal. They are required to compile an overview of the potential risks in their area of responsibility, prepare and implement a risk limitation plan and report regularly on its progress. Systematic violation of the law in their area of responsibility that has damaged the Bayer Group can have serious implications for executives if suitable measures could have prevented them from occurring. 


\section{Political lobbying by Bayer}

Politics and legislation play a key role in shaping the conditions in which we operate. As a global company, we want to actively contribute our expertise and participate in the political decisionmaking process. We see lobbying as an important and legitimate way of doing this.

We have set clear rules for these activities. These are applicable for all employees and consultants of the Bayer Group and are set out in a Group-wide Code of Conduct for Responsible Lobbying, which was issued on January 1, 2009. Since 2005, there has been a mandatory directive covering the conditions under which German employees may exercise public and voluntary offices.

To ensure transparency, Bayer was one of the first companies in the chemical and pharmaceutical sector to be entered in the European Commission's lobby register and discloses the relevant costs of its lobby work at E.U. level (€1.5 million in 2009). We are expecting a similar initiative in Germany and would enter the company in a German register if one were to be introduced.

In keeping with its directives, Bayer does not make any direct donations to political parties, related institutions, politicians or candidates for political office. However, associations to which we belong make donations on their own initiative, in compliance with the relevant statutory regulations, especially laws on party political activity. For example, the German Chemical Industry Association (VCI) makes donations to political parties on behalf of member companies. The amounts donated and their distribution among the parties are determined by the Executive Board of the vcI. In the United States, individual employees utilize the opportunity to support candidates for parliamentary office by making private donations to the Bayer Corporation Political Action Committee (BayPac). In 2009, donations totaling us\$216,500 were made to various candidates in federal and state elections.

Within the Bayer Group, uniform communication with political decision-makers is coordinated by the Community Council for Politics, which is responsible for defining the focus and priorities of the company's political affairs activities. This includes Group-wide issues such as the newsletter on research at our German sites, entries in the lobby register and subgroup-specific issues.

Key interfaces are our liaison offices in Berlin, Brussels, Washington and Beijing. Bayer collaborates closely with national and international industry associations on key political plans in the interests of a consensus-based approach. We also maintain close contact with other stakeholder groups in society, for example in the environmental and health care areas. Good collaboration with local initiatives and organizations close to our sites is also important to us. 
Effective risk management

Clear responsibilities ensure the efficient control of opportunities and risks.

\section{Effective risk management}

Business operations necessarily involve opportunities and risks. Effective and proactive management of opportunities and risks is therefore a key factor in maintaining the company's value over the long term. In the Bayer Group, the management of opportunities and risks forms an integral part of the Group-wide corporate governance system. Key elements of the opportunity and risk management system are the planning and controlling process, Group regulations and the reporting system. The qualitative and quantitative assessments of the opportunities and risks used to define the strategy of the business entities and regions are updated at regular conferences on business development, and targets and necessary actions are agreed upon.

The principles of the Bayer Group's risk management system are set forth in a Group directive. Our subgroups and service companies and the organizational units at the holding company have named risk officers at top management level and risk management coordinators to ensure the efficiency of the risk management system.

Corporate Auditing is responsible for coordinating Group-wide identification and documentation of risk factors and for ongoing development of the risk management system. The effectiveness of the risk management system is reviewed by internal auditors at regular intervals. In addition, the external auditor of the Annual Report assesses the risk management system as part of the year-end annual audit.

In 2009, we continued to develop and optimize our established risk management processes and our Group Risk Management Directive to take account of current circumstances. We regularly enter and evaluate internal and external risks in a database. The criteria for identifying and evaluating risks are set out in a procedure (BayRisk Instruction), which has also been updated.

Bayer has production facilities in more than 100 countries, some of which could be at increasing risk from the consequences of climate change, such as floods and tornadoes. An emergency response system (Bayer Emergency Response System, BayERS) to protect employees, the environment and production facilities is therefore an obligatory element in the integrated HSEQ management systems at our production sites. The basis for this is set forth in a procedure on crisis management in the Bayer Group.

In 2009, Bayer HealthCare (BHC) published its Directive on Enterprise Risk Management outlining its risk management process for production facilities. Its purpose is to ensure timely identification of potential risk factors in order to prevent them impacting the supply of our products to patients and minimize the potentially adverse consequences for the company. At all BHC production sites, potential risks are recorded and assessed and - where necessary - action is initiated. Included are risks that could affect production, the fields of health, safety, environment and quality (HSEQ), procurement and potential natural disasters. The globally standardized methodology provides a transparent and uniform overview of risks as a basis for deciding on any necessary counteraction.

Moreover, in 2009 Bayer HealthCare issued special directives and contingency plans to prioritize the medicines to be produced, their delivery and the protection of employees in the event of a pandemic.

Bayer participates in European trading in emissions allowances. Scenario-based calculations suggest that we will have to bear substantial additional expenses up to 2012 for rising energy prices and the purchase of emissions allowances, which could amount to up to 1 percent of 
EBITDA according to current calculations. In the United States, where we operate several power plants, Bayer Corporation voluntarily participates in trading in emissions allowances on the Chicago Climate Exchange (CCX).

As an exporter, Bayer is subject to a wide range of foreign trade regulations. Our Corporate Compliance Policy specifically requires employees to observe these laws. This calls for an efficient organization that ensures compliance with these regulations and provides for corresponding monitoring measures. Bayer's internal organization comprises export officers, export control officers and an export control department. The organizational framework is set out in the Group Directive on Organization of Export Control in the Bayer Group. Practical information on handling international trade controls is contained in a manual drawn up by Bayer Business Services in consultation with the subgroups and service companies.

\section{Managing legal disputes}

Legal proceedings are pending against Bayer in several countries and some cases were concluded in 2009. As a global company with a diverse business portfolio, the Bayer Group is exposed to numerous legal risks, particularly in the areas of product liability, competition and antitrust law, patent disputes, tax law and environmental protection. The outcome of any current or future proceedings cannot be predicted with certainty. It is therefore possible that legal or regulatory judgments could give rise to expenses that are not covered, or not fully covered, by insurers' compensation payments and could significantly affect our revenues and earnings. Further information on product-related lawsuits, antitrust litigation and patent disputes affecting our company can be found on page 241ff. of the Annual Report 2009.

\section{Investors stepping up their focus on sustainability criteria}

More and more investors are showing an interest in the extent to which companies integrate ecological and social aspects into their strategies and business activities. That is particularly true of long-term investors such as pension funds.

Bayer stock is included in a variety of sustainability indices and funds. For instance, we have been listed in the Dow Jones Sustainability Index (DJSI) World since its establishment in 1999. The analysts at the SAM rating agency have given Bayer consistently good marks on environmental aspects, for example for its contribution to climate protection, and for the overall transparency of its reporting. Moreover, Bayer once again scored more highly than in the previous year on anti-corruption and corporate governance activities.

In September 2009, we were included in the Carbon Disclosure Leadership Index (CDLI) initiated by the Carbon Disclosure Project (CDP) as the world's best company. This accolade was based on our sound and transparent reporting on our climate strategy and greenhouse gas emissions. Renewed inclusion in this index makes Bayer the only European company in the chemical and pharmaceutical sector to be included for the fifth time in succession in the CDLI.

Our successful performance in these and other sustainability ratings is an acknowledgement of our business strategy and our commitment to sustainable development.
Transparent climate reporting

We were rated as the world's best company in the Carbon Disclosure Leadership Index (CDLI). 
Our performance in sustainability indices and sustainability funds

\begin{tabular}{|c|c|c|c|c|c|c|}
\hline & \multirow[t]{2}{*}{ Index/Fund } & \multirow[t]{2}{*}{$\begin{array}{l}\text { Rating } \\
\text { agency }\end{array}$} & \multirow[t]{2}{*}{ Focus } & \multicolumn{3}{|c|}{$\begin{array}{c}\text { Bayer's performance } \\
\text { (years in which Bayer } \\
\text { was listed) }\end{array}$} \\
\hline & & & & 2007 & 2008 & 2009 \\
\hline \multirow[t]{2}{*}{ 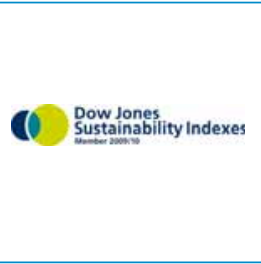 } & $\begin{array}{l}\text { DJSI World } \\
\text { (Dow Jones } \\
\text { Sustainability } \\
\text { Index) }\end{array}$ & \multirow{2}{*}{$\begin{array}{l}\text { SAM - Sustain- } \\
\text { able Asset } \\
\text { Management } \\
\text { (Switzerland) }\end{array}$} & \multirow{2}{*}{$\begin{array}{l}\text { Corporate governance, risk manage- } \\
\text { ment, innovation, environmental } \\
\text { performance, working conditions, } \\
\text { employees, HSEQ, sustainability } \\
\text { reporting }\end{array}$} & $\checkmark$ & $\checkmark$ & $\checkmark$ \\
\hline & $\begin{array}{l}\text { DJSI STOXX } \\
\text { (European } \\
\text { companies) }\end{array}$ & & & $\checkmark$ & - & - \\
\hline \multirow{3}{*}{ FTSE4Good } & $\begin{array}{l}\text { FTSE4Good } \\
\text { Global Index } \\
\text { (Financial } \\
\text { Times and } \\
\text { London Stock } \\
\text { Exchange) }\end{array}$ & \multirow{3}{*}{$\begin{array}{l}\text { EIRIS } \\
\text { (United } \\
\text { Kingdom) } \\
\text { and IMUG } \\
\text { (Germany) }\end{array}$} & \multirow[t]{2}{*}{$\begin{array}{l}\text { Environmental management, climate } \\
\text { protection, anti-corruption, human } \\
\text { rights and labor rights, sustainability } \\
\text { within the supply chain, sustainability } \\
\text { reporting }\end{array}$} & $\checkmark$ & $\checkmark$ & $\checkmark$ \\
\hline & $\begin{array}{l}\text { FTSE4Good } \\
\text { Europe Index }\end{array}$ & & & $\checkmark$ & $\checkmark$ & $\checkmark$ \\
\hline & $\begin{array}{l}\text { FTSE4Good } \\
\text { Environmental } \\
\text { Leaders Eu- } \\
\text { rope } 40 \text { Index }\end{array}$ & & $\begin{array}{l}\text { Environmental management system, } \\
\text { environmental performance, reporting }\end{array}$ & $\checkmark$ & $\checkmark$ & $\checkmark$ \\
\hline \multirow[t]{2}{*}{ BEST IN CLASS } & $\begin{array}{l}\text { Storebrand SRI } \\
\text { Funds }\end{array}$ & $\begin{array}{l}\text { Storebrand } \\
\text { (Norway) }\end{array}$ & $\begin{array}{l}\text { Environmental and social criteria, clear } \\
\text { exclusion criteria being tobacco, land } \\
\text { mines and violations of human rights }\end{array}$ & $\checkmark$ & $\checkmark$ & $\checkmark$ \\
\hline & $\begin{array}{l}\text { Advanced } \\
\text { Sustainable } \\
\text { Performance } \\
\text { Indices (ASPI) } \\
\text { Eurozone } \\
\end{array}$ & Vigeo (France) & $\begin{array}{l}\text { Sustainable corporate management, } \\
\text { relations with customers and } \\
\text { suppliers, HSEQ, employees and work- } \\
\text { ing rights, social responsibility }\end{array}$ & $\checkmark$ & $\checkmark$ & $\checkmark$ \\
\hline NYSE Euronext & $\begin{array}{l}\text { NYSE Euronext } \\
\text { Low Carbon } \\
100 \text { Europe } \\
\text { Index (LC } 100 \\
\text { Europe) }\end{array}$ & \begin{tabular}{|l|} 
Trucost (United \\
Kingdom) and \\
Credit Agricole \\
Cheuvreux \\
(France) \\
\end{tabular} & $\mathrm{CO}_{2}$ intensity in the chemical sector & $\begin{array}{l}\text { Had } \\
\text { not } \\
\text { started }\end{array}$ & $\sqrt{ } *$ & $\checkmark$ \\
\hline $\begin{array}{l}\text { access to } \\
\text { medicIne } \\
\text { Invex }\end{array}$ & $\begin{array}{l}\text { Access To } \\
\text { Medicine } \\
\text { Index ** }\end{array}$ & $\begin{array}{l}\text { RiskMetrics } \\
\text { (United States) }\end{array}$ & $\begin{array}{l}\text { Management of access to medicines, } \\
\text { R\&D, attitude to patents, pricing policy, } \\
\text { donation of medicines, voluntary social } \\
\text { commitment, transparency }\end{array}$ & $\begin{array}{l}\text { Had } \\
\text { not } \\
\text { started }\end{array}$ & $\checkmark \star * *$ & $\checkmark \star * * *$ \\
\hline CAREOM DISCLOSURE MEOAECT & $\begin{array}{l}\text { Carbon } \\
\text { Disclosure } \\
\text { Leadership } \\
\text { Index }\end{array}$ & \begin{tabular}{|l|} 
Carbon \\
Disclosure \\
Project (United \\
Kingdom) \\
\end{tabular} & $\begin{array}{l}\text { Transparency on risks and opportu- } \\
\text { nities, and corporate strategies and } \\
\text { action on climate change and climate } \\
\text { policy }\end{array}$ & $\checkmark$ & $\checkmark$ & $\checkmark$ \\
\hline
\end{tabular}

* The NYSE Euronext Low Carbon 100 Europe Index was established in October 2008.

** The Access to Medicine Index and the Carbon Disclosure Leadership Index are not trading indices.

*** The Access to Medicine Index was established in 2008.

**** Not re-assessed in 2009

WWW 57 Bayer stock I 58 Annual Report I 59 Innovation Alliance Carbon Nanotubes 60 Bayer Innovation GmbH | 61 FDA | 62 SBM Offshore | 63 CHEMPARK 64 Bayer Corporate Compliance Policy I 65 Bayer Position for Responsible Lobbying 66 E.U. register | $67 \mathrm{vcl}$ | 68 Political letter | 69 Brussels Academy 70 Chicago Climate Exchange I 71 Ratings 


\section{Employees}

The tremendous commitment of our employees plays a central role in ensur-

ing the success of our business. We therefore feel it is important to maintain a

responsible human resources policy, ranging from vocational training through

healthy working conditions and extensive continuing education opportunities

to high standards of health care and pension provision.

\section{Our employees}

The Bayer Group had 108,400 employees worldwide at the end of 2009. We thus managed to maintain our headcount almost unchanged despite the global economic crisis. This is thanks to the sustainable focus of our human resources policy, among whose aims is to retain qualified employees in the company even in economically challenging times. The constructive collaboration between the management and employee representatives is also very important for maintaining jobs and enables us to find creative solutions to safeguard employment in tough business conditions.

For example, we were able to counter the impact of the global economic crisis on staff at Bayer MaterialScience in Germany through the introduction of a solidarity pact that applied to all employees. A reduction in working hours and pay from February until the end of October 2009 helped compensate for the effects of the drop in orders and avoid the use of statutory short-time working arrangements for one employment group. In December 2009, the existing agreement under which Bayer Group companies in Germany refrain from dismissing employees for operational reasons was extended until the end of 2012.

A low staff fluctuation rate is regarded as a reliable indicator of the satisfaction of employees. Bayer's Group-wide fluctuation rate was 7 percent in 2009, but it varies by region. In 2009, it was 6 percent in North America, Latin America and the Middle East and Africa, 10 percent in Asia/Pacific and 7 percent in Europe. Alongside employee and employer-driven terminations, the fluctuation rate includes retirements and deaths.

Bayer is an attractive employer. This was once again confirmed by a large number of accolades received by the company around the world in a variety of surveys and competitions. For example, we were voted "Employer of the Year" by the Employee Services Management Association (ESM) in the United States. This honored the company's commitment to its employees and the wide range of programs and offerings that contribute to satisfaction in the workplace. In Canada, Mediacorp singled us out as one of the best employers for the third time in succession. Similarly, in Indonesia Bayer was again voted one of the best-regarded pharmaceutical companies in the country by more than 1,800 stakeholders. In Japan, the innovative workplace design and modern equipment at the new Bayer House in Osaka won the Nikkei New Office Award 2009 presented by the media corporation Nikkei Inc. and the New Office Promotion Association (NOPA).

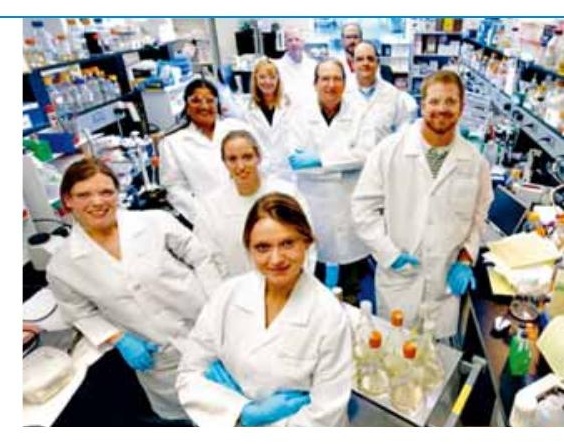

Bayer pursues a sustainable HR policy that, among other aspects, is based on diversity, equality of opportunity and social safeguards. 74 percent of our employees have access to a company pension plan.

\section{In focus}

Sustainable human resources policy

High standards of pension insurance and health care benefits

Diversity and equal opportunities for all employees

Answers to demographic change

Fostering occupational health and safety 
The Bayer Group's personnel expenses increased 3.8 percent in 2009 to around $€ 7.8$ billion. This was principally due to exchange rate effects and increased contributions to the pension assurance association.

Employees* by region and function

\begin{tabular}{lrrrrc}
\hline & $\mathbf{2 0 0 5}$ & $\mathbf{2 0 0 6}$ & $\mathbf{2 0 0 7}$ & $\mathbf{2 0 0 8}$ & $\mathbf{2 0 0 9}$ \\
\hline Europe & 45,700 & 57,800 & 56,200 & 55,500 & 54,500 \\
\hline North America & 13,100 & 17,200 & 16,800 & 17,000 & 16,300 \\
\hline Latin America/Africa/ & 10,600 & 13,700 & 14,300 & 15,300 & 16,000 \\
\hline Middle East & 13,200 & 17,300 & 18,900 & 20,800 & 21,600 \\
\hline Asia/Pacific & 41,600 & 47,800 & 48,800 & 49,100 & 47,800 \\
\hline Production & 25,200 & 37,400 & 36,900 & 38,000 & 38,900 \\
\hline Sales & 8,000 & 12,300 & 11,600 & 12,300 & 12,400 \\
\hline Research and development & 7,800 & 8,500 & 8,900 & 9,200 & 9,300 \\
\hline Administration & 82,600 & 106,000 & 106,200 & 108,600 & 108,400 \\
\hline Total & & & & & \\
\hline
\end{tabular}

*Full-time employees. Part-time employees are included pro rata based on their contractual working hours.

\section{Modern human resources administration}

Efficient personnel administration is another important aspect of human resources management. Through the Transforming Human Resources (THR) project, we have been rolling out an innovative HR operating model across the Group since 2006. The aim is to achieve a further improvement in the quality and efficiency of human resources processes and raise the contribution made by the human resources function to creating value for the operating business.

The project was successfully completed in Germany at the beginning of 2009 and the new structures were introduced in Spain, Belgium, Mexico and Brazil in the following months. From its base in Leverkusen alone, the Bayer Group's HR service center, HR//direct, is now responsible for $\mathrm{HR}$ administration for around 38,000 employees in five European countries.

In addition, the country organizations in Pakistan and Poland set up new employee portals and online applications last year to enable their employees to utilize self-service features for personnel administration and call up important information.

\section{Respecting employee rights worldwide}

In our Human Rights Position (see page 79) we give a clear undertaking to respect employee rights around the world. The working conditions for about 55 percent of our global workforce are set forth in collective or company agreements. Employees have the opportunity to form representative bodies at all our sites. Where they do not do so, we make a special effort to ensure direct and open communication. 
Bayer has a long tradition of collaboration with employee representatives from European countries. Since its establishment in 1991, the Bayer European Forum (BEF) has served as a platform for providing regular information on the development of the Group and for discussing current corporate social policy issues with representatives of the workforce. New bodies to represent employees' interests are being formed in Bayer's companies in other parts of the world as well. For example, union representation with eight elected employees was constituted at Bayer China in November 2009. Establishment of a further body to represent employees at another Group company in China is currently under discussion.

\section{Our contribution to social welfare}

Our sustainable human resources policy also takes into account the social welfare of our employees. In 2009, 74 percent of Group employees had access to a company pension plan. Since the start of 2010, a further 2,800 employees at our country organizations in Finland, Russia and Turkey have been offered company pension plans following a regular review of pension systems. In July 2009, we introduced a company pension plan for employees of Bayer companies in Bulgaria. Our employees throughout the world either have statutory health insurance or access to health insurance through the company. In countries where there is no statutory health care system or the public system only provides rudimentary cover, we arrange additional offers and initiatives to supplement state provision.

\section{Social security and the wellbeing of employees by region (percent)}

\begin{tabular}{|l|c|c|c|c|c|}
\hline Region/Area & Europe & $\begin{array}{c}\text { Latin } \\
\text { America } \\
\text { America/ } \\
\text { Africa/ } \\
\text { Middle } \\
\text { East }\end{array}$ & $\begin{array}{c}\text { Asia/ } \\
\text { Pacific }\end{array}$ & $\begin{array}{c}\text { Bayer } \\
\text { Group } \\
\text { (total) }\end{array}$ \\
\hline $\begin{array}{l}\text { Percentage of full-time employees } \\
\text { with contractually agreed working } \\
\text { weeks of max. 48 hours* }\end{array}$ & 100 & 100 & 100 & 100 & 100 \\
\hline $\begin{array}{l}\text { Percentage of employees with } \\
\text { health insurance** }\end{array}$ & 98 & 89 & 93 & 91 & 95 \\
\hline $\begin{array}{l}\text { Percentage of employees eligible to } \\
\text { take part in a company or company- } \\
\text { financed pension plan*** }\end{array}$ & 83 & 94 & 20 & 75 & 74 \\
\hline $\begin{array}{l}\text { Percentage of employees } \\
\text { covered by collective agreements, } \\
\text { especially on compensation and } \\
\text { working conditions*** }\end{array}$ & 88 & 14 & 42 & 18 & 56 \\
\hline
\end{tabular}

* Standard employment contracts, excluding exempt employees

** State or employer/employee-funded

*** Including programs to supplement statutory pension plans

**** Sector or in-house agreements 
The social data for 2009 were compiled for the first time using an electronic database. Slight differences in the results compared with previous years result from the increased accuracy of the data and a rise in the number of employees in countries where different standards of social security for employees are customary.

\section{Systematic data protection}

When processing personal data, protecting our employees and business partners has priority over third-party information requirements. A Group-wide directive on handling personal data supplements statutory provisions. Such data may only be collected for clearly defined and legally acceptable purposes and processing of such data must comply with the relevant data privacy regulations. Compliance with the directive is monitored by the data security officers at subsidiaries and by the Corporate Data Protection Officer.

\section{Open and efficient employee communication}

Bayer provides employees with regular internal information on current developments within the Group and beyond together with background information. Full and timely information for employees is provided on significant operational changes in compliance with the relevant national and international obligations. Far-reaching changes are communicated to employees through a wide range of media that are closely coordinated. Special information meetings held by the local management are a key focus.

Employees can find up-to-date information on the latest developments in the company in the intranet. Alongside the Bayer News Channel (BNC), which is available Group-wide, the countries, subgroups and service companies have their own intranet sites in their local language. The information provided for our employees is supplemented by a wide range of regular printed publications.

Regular employee surveys are very important for Bayer. Their results offer a crucial insight into the attitudes of employees from all segments of the workforce and provide subjective assessments of the company's situation. Employee surveys also give us a valuable insight into how our corporate strategy, our values and our leadership principles are taken on board and put into practice in our day-to-day activities. Within the Group, the "Pulse Check" developed by Bayer Business Services is used to survey a random sample of employees at all levels. The unfiltered results are published internally. To improve the use of employee surveys within the Group, the current surveys are to be replaced by a uniform Group-wide survey in the future. The new Bayer Employee Survey is designed to compile data annually and will be carried out worldwide for the first time in September 2010. Its modular structure means that the subgroups and service companies will still be able to include company-specific questions as well. The standardized questions in the new survey mean that the results can be compared with those of other companies, thus paving the way for further benchmark analyses. 


\section{Fostering and encouraging diversity}

Bayer regards recognizing and fostering the diverse talents, lifestyles, cultural and ethnic backgrounds of employees as an opportunity for the company and its business performance. Our diversity strategy has two main objectives: our employees should reflect the diversity in society, and they should be able to contribute and develop their skills in a discrimination-free environment. Equality of opportunity for all employees is therefore the prime factor in the selection of personnel. Our directives stipulate that the selection of personnel worldwide is exclusively based on specialist qualifications, development potential and individual performance - irrespective of gender, race, religion and sexual orientation.

Bayer is actively committed to an open and diverse corporate culture and supports associated initiatives. We are therefore a signatory to the Diversity Charter initiated by the German government. Within the Group, we run a variety of activities and campaigns to foster all aspects of diversity. Last year, Bayer HealthCare introduced

\section{Diversity as practiced in the United States}

In the United States, Bayer now has 10 different networks offering like-minded employees a platform for discussion and to represent their interests within the Group. These networks comprise:

- WAVE (Women Advocacy through Visioning and Education)

- WINGs (Women Initiative Networking Group)

- WLI (Women in Leadership Initiative at BHC)

- African American Employee Network (ACCESS) in Pittsburgh

- SGNG (Sandwich Generation Networking Group), a network for employees who are bringing up children and also caring for sick or elderly relatives

- Professional Networking Group (Links), a network to integrate and support new employees

- BASIA (Bayer Asian Society in America)

- ANGLE-B (A Network of Gay and Lesbian Employees at Bayer)

- PhAB (Pharmacists at Bayer)

- Chinese American Leaders in Berkeley (CALIBOR), a network of Chinese American employees at Bayer

"The Power of Diversity," a global informa-

tion campaign to raise employees' awareness of the importance of diversity and inform them of the related initiatives. Bayer CropScience has initiated an extensive training program in the United States with a similar objective and has also set up national and site diversity councils. In France, it has adopted an action plan to foster diversity in the workforce, and trained around 300 managers in diversity.

For a global company, having employees from as many nations and cultures as possible is a key success factor. The top management level in the Bayer Group, the Group Leadership Circle, which comprises around 400 executives, was composed of 22 different nationalities at the end of 2009, compared with just 16 only two years ago. More than 70 percent of these executives are employed in their country of origin.

To facilitate collaboration with colleagues and business partners from different cultures, Bayer HealthCare (BHC) set up the GlobeSmart online database last year to inform employees of customs and etiquette in different countries. Employee networks such as the newly founded Bayer Asian Society in America (BASIA) at BHC's Pharma Division in the United States also promote awareness and respect for other cultures and mentalities within the Group. For its extensive activities, Bayer was selected as one of the Top 10 Global Diversity Companies and Top 10 Companies for Asian Americans by the specialist journal DiversityInc. in 2009. 
Male and female employees at Bayer receive equal compensation. Individual salaries are based on each employee's personal and professional abilities and the level of responsibility assigned to them. Uniform job evaluation based on the internationally recognized Hay method is used for all managerial positions throughout the Group. Moreover, compensation paid by Bayer is based on general market conditions, which we monitor regularly through benchmarking.

Ratio of men's to women's base salaries (by employee category)

\begin{tabular}{cccc} 
Trainees & Skilled employees & Management & Senior managers \\
\hline $100 \%$ & $-{ }^{*}$ & $112.90 \%$ & $108.20 \%$ \\
\hline
\end{tabular}

* Not calculated

The differences between the basic pay of male and female employees in middle and senior management positions is essentially due to the higher percentage of men in more senior positions. Within each contractual level, differences between the genders are low and actually extend in both directions.

For technical reasons, no comparative Group-wide data are available on specialists. In areas of the Group and in jobs in which compensation falls within the scope of binding collective bargaining agreements, there are no differences in pay based on gender. This also applies for the remuneration of trainees in the Bayer Group.

\section{Steady rise in the percentage of female employees}

Fostering the employment of women is one of the central elements of our diversity strategy. At the end of 2009, the proportion of women in the workforce worldwide was around 35 percent. The percentage of female managers is rising steadily. In Germany, it is currently 24 percent across all managerial grades and nearly 30 percent at the junior management level, which is

\section{Women benefit from the SPEED program}

The SPEED program (Significant Progress in Early Executive Development) introduced by Bayer Schering Pharma in Asia demonstrates that able women in particular benefit from the present development tools. The program enables talented employees whose jobs would normally only give them a slim chance of a foreign transfer to spend between three and 12 months working outside their home base. Half of the employees who have completed the SPEED program are now women. the entry level for future managers. Moreover, the proportion is rising. At the most senior management level, the Group Leadership Circle, the proportion of women Group-wide is 5.5 percent.

We are convinced that systematic advancement of talented employees and personnel development are the best way of raising the proportion of female managers. Bayer has therefore introduced a wide range of initiatives and empowerment programs worldwide to achieve this important human resources policy objective. For example, Bayer HealthCare introduced a Women's Leadership Initiative (WLI) in the United States in January 2009 to achieve a significant increase in the proportion of female managers by 2015. Elements of the initiative include an internal mentoring program and coaching networks for female managers. In India, Bayer Business Services has succeeded in almost quadrupling the proportion of female employees through local initiatives. 


\section{Integration and support for severely disabled employees}

Integrating disabled employees and those with health problems is another component in our efforts to foster diversity among our workforce. In Germany, severely disabled employees made up 4.3 percent of the workforce in 2009. To support the employment of severely disabled employees outside the Group as well, in 2009 Bayer placed orders worth nearly €275,000 with recognized workshops for the disabled in Germany alone.

A lack of practical experience often hampers the ability of disabled employees to find permanent employment. Bayer MaterialScience has therefore set up an initiative in the United States to enable disabled people to gain work experience, thereby greatly improving their chances of finding employment with the company or beyond. Our Brazilian company has defined integrating disabled people as the focus of its diversity program this year. The activities already undertaken and those still in the pipeline are geared to improving the proportion of severely disabled employees and raising Bayer's public profile as a responsible employer.

\section{Flexible working hours}

Individual worktime models meet the varying needs of our employees. Through flextime, parttime employment and teleworking, we enable them to arrange their worktime to suit their individual needs. Nearly 15 percent of employees in Germany already benefit from these flexible worktime systems. Since 2008, employees have also had an opportunity to shape their lifetime working individually through the "BayZeit" long-term account, which enables them to build up credits from a variety of time and compensation components for use for an extensive training course or to take paid leave immediately before retirement. So far, more than 7,300 employees in Germany have used this innovative tool.

We also offer our employees various ways of combining work with personal commitments. In Germany, these include taking a break of up to seven years to bring up children, various childcare facilities and assistance in the search for carers. In the United States, "Working Mother" magazine once again included us in the 100 best employers for working mothers in recognition of our family-friendly policies.

\section{Sharing in the company's success}

A largely uniform compensation system for all employee groups and regular participation in corporate success are key elements in our human resources and compensation policy. In 2009, variable payments totaling more than $€ 460$ million were made to around 25,000 eligible employees under the Group-wide incentivization program. The level of individual payments was determined for the first time using a new method, which rewards personal performance more closely and more transparently than in the past. Moreover, in many countries and organizational units further payments are made to employees under local bonus programs. To link variable compensation to sustainability aspects, sustainability criteria are integrated into individual performance objectives wherever this makes sense in relation to the area of responsibility or activity of the employee in question.

Members of the senior management also participate in the "Aspire" long-term incentive program. Payments under this program are determined by the absolute increase in the price of Bayer shares over a three-year period (from 2010 a four-year period) and their relative performance compared with the EUROSTOxx 50 share index. In view of these demanding return targets, coupled with an appropriate personal investment in Bayer stock and the moderate level of the program, it has been regarded as a model example of a sustainability-oriented long-term incentive program since its inception in 2005. 
Employees are able to purchase shares in Bayer at a discount under various employee stock programs. In many countries, they supplement our extensive additional benefits and offer nearly 60 percent of employees worldwide a further opportunity to participate in the company and its business performance.

Management Board compensation aligned to the German Corporate Governance Code In December 2009, the Supervisory Board adopted adjustments to the compensation system for the Board of Management to ensure full compliance in the future of the compensation of the Board of Management with the new German Act on the Appropriateness of Management Board Compensation (VorstAG) and the recommendations of the German Corporate Governance Code. These adjustments are outlined below:

To further enhance the sustainability and long-term focus of the compensation structure, the previous short-term incentive (STI) for members of the Board of Management has been split into two parts. 50 percent will continue to be paid out in the following year in the same way as the STI awards for all eligible employees in the Bayer Group. The other 50 percent comprises a new stock-based long-term incentive component, comprising the granting of virtual Bayer shares, which are subject to a three-year retention period. The value of these virtual shares depends on the development of the Bayer share price during the retention period. By strengthening the longterm incentive, the weighting of the three compensation components is now around 30 percent fixed income, 30 percent STI and 40 percent LTI.

The performance period (retention period) under the current Aspire programs (Aspire I and II) is being extended from three to four years. At the same time, the performance hurdles are being raised. Established elements, such as payment caps, outperformance and average share price, are being retained.

Further, Bayer's Board of Management has given a voluntary undertaking to meet the extended share ownership guidelines. These provide that in the future the Chairman of the Board of Management should hold shares equivalent to 150 percent (previously 40 percent) of his annual fixed salary; for the other members of the Board of Management the percentage is 100 percent (previously 40 percent).

The adjustments described, which were approved by a large majority at the Annual Stockholders' Meeting 2010, have applied since January 1, 2010 to all the members of the Board of Management except those leaving during 2010.

\section{Addressing demographic change}

There will be a significant change in the age structure of the population in many countries in the coming years. The declining birth rate, especially in industrialized countries, and increased life expectancy represent strategic challenges for Bayer that we have already been addressing intensively for a number of years. 
One focus of our activities to counter demographic change is the project "Demographic Chance Management@Bayer” initiated in 2007. This has developed tools and methods to systematically analyze the demographic situation in the Bayer Group and make reliable predictions about future changes. The innovative forecasting software and related analytical method developed for this were successfully tested in selected areas of the company in 2008. In 2009, it was used to conduct a demographic test on a large proportion of the workforce in Germany, the first time such an extensive review took place.

The findings were compiled in a factbook which was submitted to corporate management. On the basis of these findings, the main areas of action for Germany have been identified and more detailed analyses have been initiated at the subgroups and service companies. Estimates made by the country organizations on the long-term development of their local labor markets are also included in our strategic considerations.

In its demographic project PROCURA, Currenta has identified six areas of action and drafted demographic guidelines. The initial measures defined in its action plan are to be introduced in 2010, along with a suitable communication program to raise employees' awareness.

\section{Age structure of Bayer's workforce}

The average age of employees in the Bayer Group is currently 41. Since it is foreseeable that lifetime working hours will increase in the coming years, a focal element of our strategy is continually upgrading the skills of employees of all ages to maintain and adapt their professional ability. Another element is expansion of occupational health management. Worldwide, we already run a wide range of programs and initiatives in this area, and we intend to gradually extend them in consultation with employees. In Germany, this is supported by the chemical industry's collective bargaining agreement on lifetime working and demographic change.

\section{Employees according to age group}

younger than $20(1 \%)$

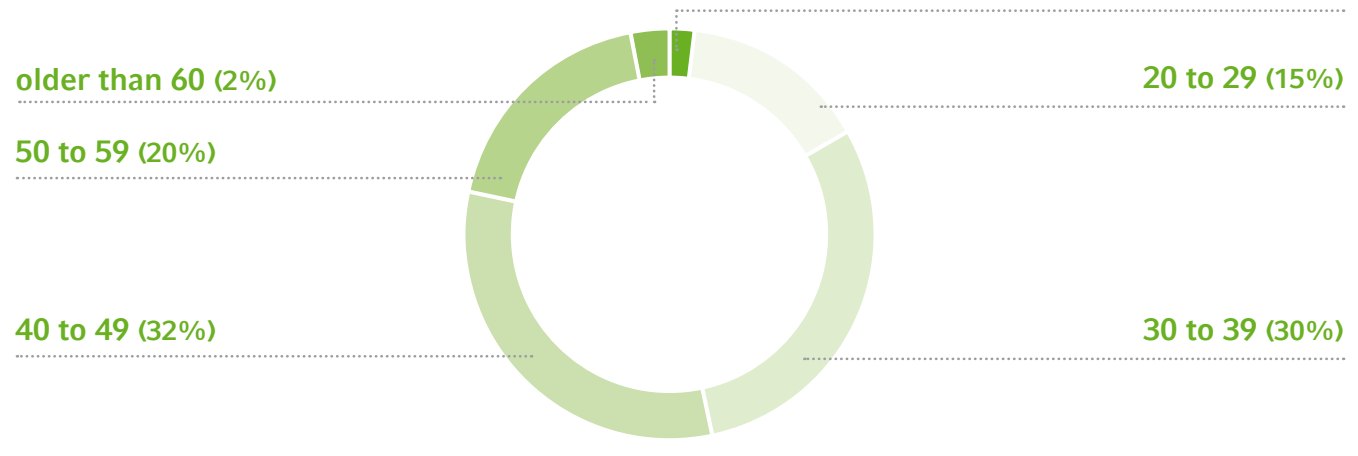

Vocational training and special programs for young employees

We regard offering young people a sound vocational training to give them a good start in working life as part of our social responsibility. In 2009, 930 young people enrolled for vocational training courses in one of more than 20 different qualifications at our German companies. Overall, Bayer currently has around 2,700 trainees. That is fewer than in 2008, principally because of a reduced number of trainees with the training provider in the service company Currenta. 


\begin{tabular}{rrrrr}
\multicolumn{1}{l}{ Trainees } & & & & \\
\hline $\mathbf{2 0 0 5}$ & $\mathbf{2 0 0 6}$ & $\mathbf{2 0 0 7}$ & $\mathbf{2 0 0 8}$ & $\mathbf{2 0 0 9}$ \\
\hline 2,700 & 3,100 & 2,700 & 2,900 & 2,700 \\
\hline
\end{tabular}

In 2009, the European Union's “Learn by S(t)imulation” project confirmed that this investment in the future pays off: the trainees from Currenta who took part in this competition secured first

\section{Jump start for young people}

A total of 156 young people with low educational attainment levels have benefited from our special program to prepare them for vocational training. Around 1,600 young people have taken part in this program since it was established more than 20 years ago and about 85 percent subsequently qualified for vocational training programs. place. A study by the RheinMain University of Applied Sciences in Wiesbaden last year confirmed that our careers website is one of the three best online portals for young people in Germany looking for a vocational training place. That is an important factor in our endeavors to attract the best applicants for our company in spite of the declining number of school students.

Internationally as well, Bayer offers young people opportunities to gain a basic training. In cooperation with local branches of the German chambers of commerce and local educational institutes, we have for many years offered young people in numerous countries in South and Central America and Europe and in the People's Republic of China a sound vocational training based on the standards and principles of the German system.

In addition, we actively endeavor to interest talented youngsters worldwide in our company. As well as offering more than 1,230 stimulating internships for students in a variety of disciplines, we have cooperations with renowned universities and international student organizations on all continents. For example, Bayer supports "Students in Free Enterprise" (SIFE), the world's largest independent student initiative for sustainable enterprise and responsible business conduct. For the past four years, Bayer has provided the president of the German section of SIFE and it played a key role in organizing the SIFE World Cup in Berlin last year. The success of our wide-ranging activities was confirmed last year by the results of a joint survey by the German business magazine "Wirtschaftswoche" and the consultancy company Universum Communications. According to their analysis, Bayer is the second most popular employer for young scientists in Germany.

Our company's student support activities helped us to recruit around 5,000 university graduates to Bayer companies as technical or managerial employees in 2009. China hired around 1,500 employees with an academic background in 2009, putting it at the head of the league, followed by the United States with 965 and India with 525 .

\section{Ongoing training and personnel development}

Ongoing training of employees plays a key role in our human resources strategy. Technological change, progressive globalization and maintaining and upgrading knowledge over a longer working life are just some of the reasons that drive employees to upgrade their personal and professional skills. Our human resources strategy is geared to fostering and utilizing the individual potential of our employees. Acquiring, extending and maintaining professional knowledge is one aspect of this, while targeted human resources development is another. 
Owing to the effects of the global economic crisis, our investment in the vocational and further training of our employees in 2009 did not quite reach the level for previous years. The consistently high standard of ongoing training is guaranteed by our quality management. In Germany this has been validated externally as complying with Iso 9001.

\begin{tabular}{ccccc}
\multicolumn{4}{l}{ Vocational and further training expenses (percent of personnel expenses) } \\
\hline $\mathbf{2 0 0 5}$ & $\mathbf{2 0 0 6}$ & $\mathbf{2 0 0 7}$ & $\mathbf{2 0 0 8}$ & $\mathbf{2 0 0 9}$ \\
\hline 2.3 & 2.2 & 2.0 & 2.7 & 1.9 \\
\hline
\end{tabular}

In 2009, we added a wide range of new programs and initiatives to extend our extensive development tools. The "Niev" management program introduced in India in September 2009 offers talented employees an opportunity to study management while they are working. In Australia, Bayer HealthCare has introduced the "Talent Management Transparency" project to enhance the transparency of internal personnel development and succession planning and encourage employees to make more effective use of opportunities for advancement. This objective is shared by Bayer CropScience's information campaign "Your Career at Bayer," which aims to raise the awareness of managers and employees of their responsibility for successful personnel development.

The IT Mentoring Program run by Bayer Business and Technology Services (BBTS) in the United States is another example of how we actively apply the obligation to develop oneself and others enshrined in our Values and Leadership Principles. Through this program, experienced managers share their knowledge with younger colleagues and thus support their professional advancement.

In addition to these new initiatives, Bayer's employees still have access to the company's established development programs. In 2009, more than 1,800 employees received feedback on their leadership behavior from employees, colleagues and business partners through the Bayer $360^{\circ}$ Feedback system. A further 1,250 employees use the structured Development Dialogue to agree a development plan for the coming year with their managers to help them put their professional ambitions into practice. In addition, more than 40,000 employees across the Group regularly receive a performance appraisal from their supervisors through our global performance management system alone.

\section{Occupational health and safety}

Fostering the health of our employees in the workplace is one of the most important goals of our health, safety, environment and quality (HSEQ) activities. Identifying and assessing potential dangers and managing the related risks are core elements of Bayer's endeavors to protect health in the workplace. These aspects form an integral part of the HSEQ management systems at the subgroups and service companies, which include avoiding occupational health hazards, and protecting and promoting the health of employees. These processes are defined in the new Group directives on occupational health and safety which were introduced in 2009.
Safety

In 2009, our new directives on occupational health and safety came into force. 
Worldwide, our subgroups and service groups are working to make Bayer's workplaces even safer. The new occupational safety directive adopted in 2009 should also make a major contribution to this. It sets out actions and procedures to prevent accidents at work and investigate the causes of any accidents that nevertheless occur. The findings have to be translated into action to prevent a recurrence. At the same time, systematic and practically oriented contingency plans and precautions are designed to minimize the impact of accidents.

In 2009, we almost achieved our goal of reducing the lost time injury frequency rate to less than 2.0 injuries per million working hours (million working hour quota $=\mathrm{MAQ}$ ) by 2010. The MAQ declined from 2.2 in 2008 to 2.0 in 2009. The ratio of reportable injuries based on Bayer's definition also fell, namely from 3.6 to 3.1 year-on-year.

\section{Occupational injuries affecting Bayer employees}

\begin{tabular}{lcccccc} 
& 2005 & 2006 & 2007 & 2008 & 2009 & Target* $^{*}$ \\
\hline $\begin{array}{l}\text { Occupational injuries to Bayer } \\
\text { employees resulting in days lost } \\
\text { (MAQ**) }\end{array}$ & 2.7 & 2.8 & 2.4 & 2.2 & 2.0 & $<2.0$ \\
\hline $\begin{array}{l}\text { Reportable occupational injuries } \\
\text { to Bayer employees (MAQ }\end{array}$ & 4.0 & 4.3 & 3.7 & 3.6 & 3.1 \\
\hline \begin{tabular}{l} 
Fatal accidents (total) \\
\hline of which Bayer employees
\end{tabular} & 4 & 9 & 4 & 2 & 4 \\
\hline $\begin{array}{l}\text { of which contractor } \\
\text { employees** }\end{array}$ & 1 & 4 & 0 & 0 & 0 \\
\hline
\end{tabular}

* Target to be achieved by 2010 based on 2005 figures

** MAQ = million working hour quota (injuries per million hours worked)

***Employees working for third parties

Unfortunately, Bayer employees died in four fatal accidents at our sites in Beijing, Valencia, Thailand and Leverkusen in 2009. Two of these were traffic accidents during worktime, one death resulted from an accident when a fork-lift truck overturned and a fourth involved a fall from a crane.

Bayer responds rapidly and comprehensively to accidents and identified shortcomings. Following the death of two employees as a result of an explosion at Bayer CropScience's site in Institute, West Virginia in the United States in 2008, the company will invest us\$25 million to improve safety standards at the site. One key measure comprises reducing the amount of methyl isocyanate stored at the site by 80 percent by August 2010. Improved emergency communications systems were installed in 2009.

All subgroups and service companies organize a wide range of programs to promote occupational health and safety as part of their HSEQ obligation. "Fit in Production" (FIP) is a program run by Bayer MaterialScience (BMS) to ensure that all employees worldwide receive uniform training in the correct conduct at work and in emergency situations. The occupational safety initiative run by Bayer MaterialScience at its facilities at CHEMPARK sites in Germany focuses on traffic safety, noise protection, mutual support in safety-related conduct and correct use of electrical appliances. In 2009, BMS introduced a cEO Safety Award to improve the safety of employees and working processes and raise general awareness of safety within the company. The cEo Safety Award builds on the core processes of the BMs Integrated Management System and uses the corresponding expert network as a global platform for sharing and evaluating safety programs. 
Bayer HealthCare's global accident prevention initiative "Managing Safety!" focuses on emergency response and accident prevention. As part of this program, local occupational safety initiatives have been developed and introduced at many sites. Moreover, to reduce accidents in sales organizations, a global Road Safety Initiative has been established to foster safety among members of the field force.

Bayer CropScience has set itself the goal of reducing the number of injuries resulting in days lost to no more than 1.0 per million hours worked. To achieve this, it is stepping up its occupational safety programs. The main ele-

\section{Accolade for Bayer Thai}

Bayer Thai's production site in the Map Ta Phut industrial district received the Prime Minister Industry Award 2009 for its outstanding safety concept. This award is based on an evaluation of the safety training and motivation of employees, fire prevention and emergency response plans, and injury statistics for the past three years. ments are safe driving, updating workplace hazard assessments, new accident prevention campaigns and training in safe working practices. Workshops will be run at the sites to enhance awareness of the importance of occupational health.

In view of the increase in accidents at work, in 2009 Currenta introduced a long-term accident prevention program "Joining forces to improve safety." Around 100 events, discussions, training sessions, training documents and short films are being used to achieve the three main goals of this initiative: a lasting reduction in the number of injuries, the fostering of a safety-conscious corporate culture and the implementation of a long-term health protection strategy.

\section{Modern health management}

Providing general preventive health care and medical advice for our employees is very important to us. This applies above all in less developed countries, where our company-financed offers are often able to make up for shortfalls in public health care provision. As a responsible modern employer, Bayer offers employees in many countries a range of programs and initiatives. Their scope and type depend on the specific needs of the local workforce.

For example, Bayer CropScience introduced a "heart program" at its site in Bangpoo, Thailand. Bayer is also conducting a program to vaccinate employees at the site against hepatitis B. Health education measures and regular medical check-ups for all employees round off the services.

Widespread obesity and the resulting health problems among members of the workforce at Bayer CropScience's Canlubang site on the Philippines triggered an innovative sports program for employees in 2008 and 2009. This initiative proved so successful that a new round is to be organized in 2010. For its staff in the Philippines, Bayer CropScience also offers preventive medical check-ups for all employees, along with influenza vaccinations and an extensive sports program.

Bayer Schering Pharma established a Company Health Management working group in Berlin last year to develop site-specific health management and social policy. This will supplement the present offers of medical advice and assistance for employees. These include annual health management days and information campaigns to raise awareness of present health risks. A Work Ability Consulting (WAC) working group helps managers at Bayer HealthCare meet their duty to protect employees. Various medical advisory offerings are included in the wide range of seminars and health management activities organized by Bayer Business Services for Group companies in Germany. 
Bayer CropScience offers similarly extensive occupational health management in Australia comprising different programs and seminars tailored specifically to the needs of various employee groups. The spectrum ranges from changing monthly health care offerings to training in the correct working posture and the right way to lift heavy loads.

Currenta assumes responsibility for health protection on behalf of the subgroups and service companies at the German sites in Leverkusen, Krefeld-Uerdingen, Wuppertal-Elberfeld and Dormagen. This comprises basic health care by company physicians and acute and preventive medicine. Currenta is particularly active in systematic occupational health management, also in view of the upcoming demographic trends. By amalgamating the results of employee surveys, analyzing absences, assessing dangers and carrying out preventive medical checks it aims to develop and introduce suitable activities. For many years, Currenta has offered employees psychosocial advice, help with addiction and dealing with conflicts and occupational health management, including reintegration of employees after prolonged periods of illness.

Promoting, maintaining or restoring a work-life balance is becoming another increasingly important aspect of occupational health management. In the United States, special WorkLife programs are designed to achieve this. In Pittsburgh, Bayer also offers employees and their families "Wellness Works," a pilot program to identify health risks and promote a healthy lifestyle. The pilot project is to be rolled out nationwide, probably at the end of 2010.

Many offers enable our employees to take physical exercise during or after working hours, thus combining health management with their personal interests. In Canada, the "Fit at Work" program allows employees access to a gym during working hours, while fitness training for employees at some U.S. sites is encouraged by subsidizing sports centers.

Bayer is also prepared for global threats to health, a policy that proved its worth in the face of the H1N1 pandemic. The company's pandemic crisis plans were implemented as necessary, and the employees were continuously informed of the latest developments and given suitable recommendations. Experience with the H1N1 pandemic has led to a thorough review of the crisis plans and the drafting of a Group directive on the issue of precautions in the event of a pandemic.

WWW 72 Employees | 73 Employee Services Management Association I 74 THR 75 Bayer Human Rights Position I 76 Diversity I 77 Charter of Diversity 78 Diversity at Bayer in the United States | 79 Working Mother | 80 Bayer stock 81 Stock programs for employees | 82 Corporate governance | 83 VorstAG $\mathbf{8 4}$ Jobs and careers | 85 Jump start program | 86 SIFE 


\section{Human rights}

Bayer supports the Universal Declaration of Human Rights of the United Nations. Furthermore, as a founding member of the UN Global Compact, the company undertakes to implement the 10 universally recognized principles in the areas of human rights, labor standards, environmental protection and anti-corruption throughout the company when shaping business processes and strategies.

\section{Our clear position on human rights}

These principles are also anchored in the Bayer Human Rights Position. In addition, our values and leadership principles, the Bayer Sustainable Development Policy and our Corporate Compliance Policy obligate our employees across the Group to conduct themselves respectfully toward colleagues, employees, business partners and customers.

We published the Bayer Human Rights Position for the first time in the Sustainable Development Report 2006. In 2007, it took effect as a binding directive for all employees Group-wide; it was most recently updated in 2009.

\section{Our position on human rights: communication and training}

All managerial staff in our company are obligated to implement our Human Rights Position within their scope of responsibility and sensitize their employees for the importance of this issue in the everyday work environment. To this end, an information brochure explaining our Human Rights Position was sent to more than 7,500 managers in the German-speaking countries at the end of 2008. Last year, we supplemented the brochure with an extensive training presentation on human rights in which the objectives and content of our Human Rights Position are vividly illustrated and communicated by means of numerous examples.

Both communication media were made available to all Bayer country companies at the beginning of 2010 as part of a Group-wide information campaign - allied to the request that employees be trained using the presentation and the brochure distributed to local managerial staff. The information campaign is also supported by an e-learning tool that familiarizes new employees with our Human Rights Position soon after they join the company.

Beyond the new training presentation, the observation of human rights is taught in many other training courses and seminars organized by Bayer worldwide. One example is the managerial employee training course offered by Bayer HealthCare in Switzerland under the title "Respect for People." Human rights aspects also form part of the regular compliance training sessions.

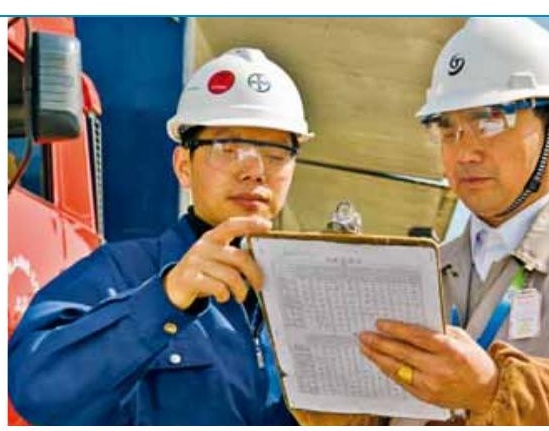

For us, close cooperation and dialogue - as here between Bayer employee Guan Lian Jun (left) and supplier Huan Wei - form the basis for sustainable procurement management.

In focus

Support of the Un's Universal Declaration of Human Rights

Voluntary commitment to the 10 principles of the un Global Compact

Bayer Human Rights Position binding on all employees worldwide

Bayer's Supplier Code of Conduct underlines respect for human rights in the supply chain

Bayer CropScience Child Care Program sets standards in the protection of children's rights 


\section{Clear standards for supplier management}

Bayer's Supplier Code of Conduct, which came into force at the end of 2009, is also based on sustainability principles and our Human Rights Position. Bayer expects its suppliers to adopt the principles spelled out in this code of conduct, observe human rights and treat their employees with fairness and respect. The code is based on the principles of the UN Global Compact.

With this code of conduct, we aim to strengthen a common understanding about how to implement sustainability in our and our suppliers' everyday business operations. The selection and evaluation of our suppliers is based partly on their degree of observation of the principles contained in the code of conduct, which we have verified since the end of 2009 according to specific criteria. This process is governed by a dedicated procedure on supplier selection and evaluation. One important element of the new procedure is a three-stage modular training program that all of our purchasers are obligated to complete so that they know how to apply the code when dealing with suppliers (see page 22f.)

\section{Special protection for children}

Unfortunately, child labor is still widespread in many countries. In a number of regions in which we are present and maintain business operations, children traditionally are still used for activities such as field work to contribute to the subsistence of families.

Following our acquisition of the Indian seed company Proagro at the end of 2002, we began establishing measures to tackle child labor in our cotton seed supply chain. Through the Bayer CropScience Child Care Program, Bayer CropScience takes resolute and systematic action against child labor in India and helps to assert children's rights.

The program works on various levels, with the most important objective being to achieve a change in people's awareness. Agriculture can indeed be pursued cost-effectively without the deployment of children, and education through school attendance is the key to improving their living circumstances in the long term. Conveying this message forms the focus of our communication activities and personal dialogue with the farmers and general population in the affected communities.

\section{2,400}

To date, more than 2,400 children and young people have taken part in the "Learning for Life" initiative.
The program also offers special education and training opportunities to children and young people in the regions in which we operate. Working together with local non-governmental organizations and institutions, we provide children with opportunities ranging from reintegration into the regular school system to vocational training through our "Learning for Life" initiative. More than 2,400 children and young people so far have benefited from these educational opportunities. At the Bayer Ramanaidu Vignana Jyothi School of Agriculture, for example, we provide young people with vocational training culminating in qualification as farm assistants.

Bayer CropScience concludes contracts with seed suppliers that contain a strict "no child labor clause." These contractual agreements are explained in discussions with our partners and meaningfully supported by our communication measures in the villages. Several times a year, special monitoring teams make unannounced visits to the fields to ensure compliance with the clauses. They check the ages of the workers and document this information. The producers receive a bonus at the end of the planting season if no child labor was discovered. In the event that these rules are violated, a graded system of sanction measures takes effect that ranges from an oral warning and the loss of this special bonus to the cancellation of the contract in the case of repeat offenses. If a rare case of child labor is nonetheless discovered, we talk with the farmer in whose field the violation took place, as well as with the child's parents to persuade them to send the child to school. The monitoring system in the fields is inspected through internal audits on a 
periodic basis. In addition, surprise field visits are undertaken by Ernst \& Young Private Limited, India, once a year at randomly selected sample farms in a relevant number. During these checks, observance of the strict ban on child labor and also compliance with the monitoring procedures under the Bayer Child Care Program Management System (CCPMS) are reviewed.

To manage the program in India, a steering committee was deployed comprising the Senior Bayer Representative of the Bayer Group and the Country Head of Bayer CropScience in India, the managerial staff responsible for seed production, the leaders of the Child Care Program and the responsible employees of Bayer CropScience Communications.

We also ensure the additional involvement of important stakeholders through an Advisory Council established in 2008. This body includes not just representatives of Bayer CropScience, but also the following recognized experts from the scientific and developmental cooperation fields:

- The cEO of the Fair Labor Association, Auret van Heerden

- The Dean of Social Science at the Theological University of Friedensau, Professor Horst Friedrich Rolly

- The India Country Director of the German Society for Technical Cooperation (GTZ), Dr. Guenter Dresruesse

- A representative of The Energy and Research Institute (TERI) of India

The task of the Advisory Council is to advise the representatives of the Bayer CropScience Child Care Program on strategic content, such as on ethical production methods in the seed supply chain or the development of educational programs in rural areas. The council meets as often as required, but at least once a year. The first meeting took place on February 6, 2008, the second on December 11, 2008 and the third on November 20, 2009.

In 2009, we further expanded the Bayer CropScience Child Care Program that was originally developed for the area of cotton seed production, also introducing systematic field monitoring in vegetable seed production. The program will be expanded in 2010 to include our growing hybrid rice seed production activities.

Bayer CropScience also works with other companies on an international level to advocate the implementation of a child labor moratorium: on June 12, 2009 - World Day Against Child Labor the international association CropLife International published a position paper against child labor in the seed supply chain that was drafted primarily by Bayer CropScience, Syngenta, Monsanto and Du Pont. The paper was initiated at a "round table" organized by Norges Bank Investment Management (NBIM). Also involved in drafting the paper were non-governmental organizations such as the Fair Labor Association and inter-governmental organizations such as the International Labor Organization (ILO) and the United Nations International Children's Emergency Fund (UNICEF).

Further information on the Bayer CropScience Child Care Program is contained in a brochure of the same name published in 2009.

WWW 87 un Declaration of Human Rights | 88 UN Global Compact 89 Bayer Sustainable Development Policy I 90 Bayer Corporate Compliance Policy 91 Bayer Human Rights Position I 92 Bayer Supplier Code of Conduct 93 Tackling child labor I 94 Fair Labor Association 95 Friedensau Adventist University | 96 GTZ | 97 TERI | 98 CropLife International 99 International Labor Organization I 100 UNICEF 


\section{Corporate social responsibility}

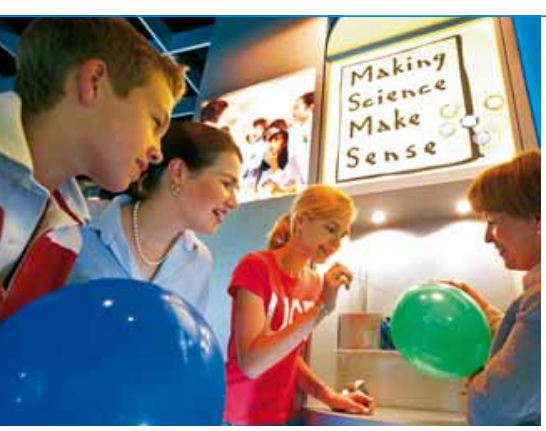

Under our "Making Science Make Sense" program, employees volunteer to visit schools to demonstrate the benefits of science with the aid of hands-on experiments.

\section{In focus}

Commitment to corporate social responsibility as a good corporate citizen

Focus on issues of global or particular social relevance in countries in which Bayer operates

Commitment to areas with a link to our business operations and corporate expertise

Support and encouragement of voluntary work by our employees
Corporate social responsibility (CSR) is an integral part of Bayer's corporate

philosophy and has a history at the company dating back over 100 years. Our primary objective is to reconcile economic success with environmental protection, conservation of natural resources and social concerns.

\section{Our philosophy}

We consider ourselves to be a responsible member of society and a good corporate citizen. We see our CSR activities as a long-term investment in the future well-being of society and our company.

Our corporate social responsibility activities are designed to have an enduring impact. The focus is on issues that have global or particular social relevance in countries in which Bayer operates. We endeavor to provide technical and economic expertise to back up our employees' commitment in areas which have a link to our business operations. We employ a variety of tools ranging from our own projects (often in cooperation with partners), corporate volunteering and donations (financial aid, medicines and materials) to the support programs of the Bayer foundations and the activities of our sports clubs and Bayer Arts \& Culture.

Despite falling sales in 2009 , the Group set aside $€ 44$ million for support projects across the globe in the key areas of Education \& Research, Environment \& Nature, Health \& Social Needs, and Sports \& Culture. Although CSR expenditure was around €5 million lower than in 2008, this was not fully the result of a reduced financial commitment to our core sustainability programs, but was caused by decisions not to implement additional one-off measures.

\section{Our management strategy}

Around half of the sum of $€ 44$ million Bayer spends on its CSR activities is financed by budgets administered at Group headquarters. This includes the funds of the two Bayer foundations. The other half is made available through the local csR budgets of the Group companies. As with the projects we initiate ourselves, professional project management is an aspect we consider to be especially important in third-party projects we provide funding for - and that means in particular a goal-oriented approach, effectiveness, sustainability, efficient and transparent use of funds, and evaluation of support measures. 
A Group-wide directive establishes a framework for the strategic alignment and proper handling of all charitable donations. The Group Management Board's approval is required for amounts exceeding €10,000. Since 2006, Bayer has applied a systematic reporting procedure for its global social commitment.

\section{Social commitment in 2009: overview of expenditure}

\begin{tabular}{|c|c|c|c|}
\hline & $\begin{array}{c}€ \\
\text { thousand }\end{array}$ & $\begin{array}{l}\text { Share } \\
\text { of total } \\
\%\end{array}$ & $\%$ \\
\hline Education \& Research & 4,879 & 11 & \\
\hline $\begin{array}{l}\text { Science education in schools } \\
\text { (e.g. "Baylabs" school support program, scientific } \\
\text { competitions, "Making Science Make Sense" initiative) }\end{array}$ & 1,703 & & 34.9 \\
\hline Student scholarships & 946 & & 19.4 \\
\hline Support for science and research (e.g. awards, chairs) & 1,851 & & 38.0 \\
\hline General school education & 314 & & 6.4 \\
\hline Other & 65 & & 1.3 \\
\hline Environment \& Nature & 2,659 & 6 & \\
\hline Environmental education with the focus on youth & 2,143 & & 80.6 \\
\hline Nature preservation and biodiversity & 265 & & 10.0 \\
\hline Sustainable agriculture & 176 & & 6.6 \\
\hline Other & 75 & & 2.8 \\
\hline Health \& Social Needs & 15,213 & 35 & \\
\hline Public health programs (e.g. access to contraceptives) & 8,358 & & 54.9 \\
\hline Health education & 2,770 & & 18.2 \\
\hline Social community projects & 1,953 & & 12.8 \\
\hline Support for patient organizations & 1,072 & & 7.1 \\
\hline Medical research (non-profit) & 489 & & 3.2 \\
\hline Social volunteer projects & 280 & & 1.9 \\
\hline Disaster aid & 272 & & 1.8 \\
\hline Other & 19 & & 0.1 \\
\hline Sports \& Culture & 20,768 & 48 & \\
\hline Bayer sports clubs & 14,898 & & 71.7 \\
\hline Bayer Arts \& Culture & 4,778 & & 23.0 \\
\hline Bayer cultural clubs & 573 & & 2.8 \\
\hline Other & 519 & & 2.5 \\
\hline
\end{tabular}

\section{Promotion of education and research}

Society as a whole, and Bayer as a research-oriented company in particular, is reliant on having an up-and-coming generation of young people with a sound scientific education. That is why we invest in scientific and technical education at schools, support talented students and honor outstanding research achievements. In the year under review, the Bayer Science \& Education Foundation provided just under $€ 1$ million in funding for appropriate support programs in Germany. 


\section{Awards by the Bayer Science \& Education Foundation}

In 2009, this foundation presented the newly established Bayer Early Excellence in Science Award to three young scientists, who received $€ 10,000$ each. The recipients were Dr. Jürgen Groll of RWTH Aachen University in Germany for the "Materials" field, Dr. Noriyuki Nishimura from the University of California, San Diego, United States, in the "Biology" category, and Dr. Tobias Ritter of Harvard University in the United States for "Chemicals."

The Hansen Family Award 2009 went to Professor Patrik Cramer for his research work in the field of molecular research. The recipient of the Otto Bayer Award 2010 was Professor Detlef Weigel from the Max Planck Institute for Development Biology for his outstanding research work in the field of plant genetics. In 2010, the prize money for the two awards, which are presented every two years alternately, was increased from $€ 50,000$ to $€ 75,000$ each.

Another prize presented by the foundation is the Bayer Climate Award. You can read more about this on page 47 .
The Bayer foundation invested just under $€ 500,000$ in 51 schools situated close to our sites in Germany to improve the conditions for science teaching.

In 2009, Bayer supported talented students in Germany and worldwide with grants totaling just under €1 million.

In the same year, Brazil joined the list of countries participating in Bayer's educational program "Making Science Make Sense," which means schoolchildren in a total of 12 countries are now benefiting from the voluntary involvement of Bayer employees who visit schools to demonstrate the fascinating aspects and benefits of science with the aid of hands-on experiments. The Group further facilitates this commitment on the part of its employees by providing some €350,000 in funding for training measures and teaching materials.

\section{Encouraging a judicious approach to nature and the environment}

As a company with international production operations, Bayer considers environmental protection, nature conservation and the judicious use of natural resources to be an important part of its social responsibility. Given that the next generation will have a major role to play here, one of the company's key areas of focus is encouraging the environmental commitment of young people across the globe and raising their awareness of environmental issues.

As part of our global partnership with the United Nations Environment Programme (UNEP), we supported joint projects in 2009 with $€ 1.2$ million of funding and additional non-financial assistance. The focus was on the International Children's and Youth Conference on the Environment in the South Korean city of Daejeon, with 600 participants from some 100 countries. Thanks to a particularly enthusiastic response from China, the 18th unEP-Bayer International Children's Painting Competition received a record-breaking 2.4 million entries from 89 countries. Also, the Bayer Young Environmental Envoy program was expanded to include Chile - now the 19th participating country.

In China, Bayer launched a special environmental protection program called "Seeding for Green" to lay the foundation for a green future. One aspect of this program is making young people and the population in general more environmentally aware. Our initiatives under the program include the Bayer Environmental Award for Media and a children's book about global warming.

Under its Bayer Climate Program, the company recognizes significant contributions to the scientific debate on climate change. Its aim is to draw attention to the great relevance to society as a whole of research in climate sciences. In 2008, the Bayer Science \& Education Foundation initiated the Bayer Climate Award. This award worth €50,000 is presented every two years. The 2010 winner is Professor Peter Lemke from the Alfred Wegener Institute for Polar and Marine Research (AWI) in Bremerhaven, Germany (see also the Focus Issue Climate Protection on page 47). 


\section{Global commitment to health and social needs}

Bayer demonstrates an active commitment to improving social conditions and health services in many regions of the world with the dual aim of promoting social stability in the communities near its sites and helping to solve global health problems. We are able to draw on the company's particular expertise and many years of experience in the field of health care.

We take on global responsibility in this field through partnerships with the World Health Organization (WHO) and other organizations, such as the German Foundation for World Population (DSW) and the United States Agency for International Development (USAID) (see also Focus Issue Health on page 30f.).

In 2009, the volunteer program of our foundation for corporate social responsibility - the Bayer Cares Foundation - provided more than $€ 100,000$ in funding to support 42 projects close to our German sites. At the beginning of 2010, the program was extended to the Bayer sites in Latin America, with the initial inclusion of six projects in which Bayer employees and members of the public provide active and exemplary support to improve local living conditions.

Another important area is aid for victims of natural disasters. For decades, Bayer has been donating medicines, materials and financial aid to help people in desperate need around the world. For example, we donated medicines worth more than $€ 660,000$ to the victims of the earthquake in Haiti in January 2010. In addition, employees in 34 countries responded to the appeal by Group management and donated a total of €255,000 for a long-term reconstruction project, to which the company added an extra €100,000. Furthermore, a donation of us\$100,000 from the company was used to build emergency accommodation for the victims of the earthquake in Chile in February 2010.

\section{Traditional commitment to sports and culture}

Bayer has a long history of encouraging clubs and has been committed to sports for more than 100 years. The company's three focal points in this respect are popular, youth and disabled sport. The 50,000 active members of the 27 Bayer clubs at our German sites - around half of them Bayer employees - benefit from a wide range of opportunities to practice sport as a valuable leisure pursuit and to keep fit and healthy in the process. Our involvement in professional soccer is not part of our voluntary corporate social responsibility program but comes under the Group's image advertising activities.

Bayer has also served as a patron of the arts for more than a century. The extensive program of events organized by Bayer Arts \& Culture and our support for a range of ensembles and societies make a significant contribution to cultural life and enhance the attractiveness of our corporate locations.
Aid following natural disasters

Bayer donates medicines, materials and financial aid. 


\section{Ecology}

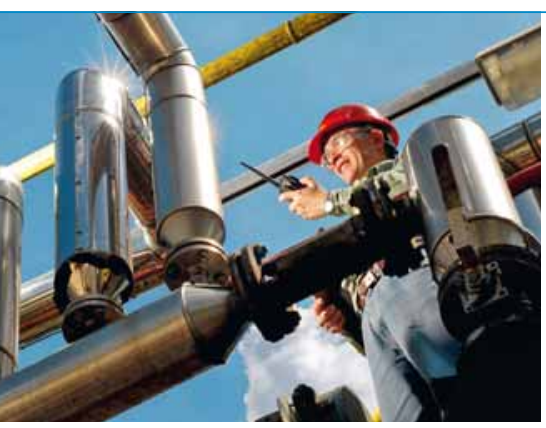

By optimizing processes and production plants we were able to reduce our energy consumption further. Facilities all over the world such as this one in Belford Roxo in Brazil are regularly inspected.

\section{In focus}

Responsible approach to resources

Reduction of emissions into air and water

Use of tools of analysis: Climate Check and Resource Efficiency Check

Reduction in waste volume

Avoidance of environmental incidents and transport accidents

Protection of biodiversity

\section{Bayer has long placed great importance on protecting the environment and} conserving natural resources. We leverage our expertise in technology, process optimization and product innovation to protect nature, the environment and the climate. We are continuously developing new solutions to optimize resource utilization and emission levels, as well as to minimize waste generation,

\section{Energy consumption}

The Bayer Group saw a reduction in all the individual items in the energy balance sheet in 2009. The total energy consumed was 77.3 petajoules, 6.6 percent less than in the previous year. The reduction in energy use was caused primarily by a 13 percent drop in production in the period under review due to economic circumstances. For example, the two production sites in Baytown, United States, and Brunsbüttel, Germany, had entire production lines taken out of service at various times during the reporting period. Meanwhile, the Caojing site in China experienced a significant increase in energy consumption resulting from the expansion of production activities there.

When determining energy use for the Bayer Group as a whole, we focus specifically on energy consumption rates at our production sites. For the purely administrative sites, at which data are not collected, we have performed a qualified estimate of energy consumption. Energy consumption at these sites was of the order of 1 percent of the total energy use for the Group.

\begin{tabular}{lccccc}
\hline Energy consumption & $\mathbf{2 0 0 5}$ & $\mathbf{2 0 0 6}$ & $\mathbf{2 0 0 7}$ & $\mathbf{2 0 0 8}$ & $\mathbf{2 0 0 9}$ \\
\hline $\begin{array}{l}\text { Absolute energy consumption } \\
\text { (petajoules) }\end{array}$ & 82.4 & 80.5 & 85.3 & 82.8 & 77.3 \\
\hline $\begin{array}{l}\text { Volume of products sold } \\
\text { (million metric tons) }\end{array}$ & 9.7 & 10.1 & 10.6 & 10.0 & 8.7 \\
\hline
\end{tabular}

Specific energy consumption in relation to the volume of sales products produced increased in the year under review. The worsening of this indicator can be essentially attributed to the economic crisis and the resulting reduced capacity utilization. A degree of utilization that is far from ideal and start-up and shutdown processes caused by economic conditions automatically lead to a poorer figure for specific energy consumption. Other influencing factors include shifts in the product portfolio and start-ups of new facilities with new technologies.

Energy consumption is broken down further in the energy balance sheet presented on the next page. The starting point is the use of primary fuels for the generation of energy within the Group, which is reported as primary energy conversion. Steam from waste heat and procured electricity (excluding electricity passed on to third parties) are added to this in order to determine what is defined as the total energy volume. The total energy use is obtained by deducting sales of steam and refrigeration energy. This is also termed the "absolute energy use." 


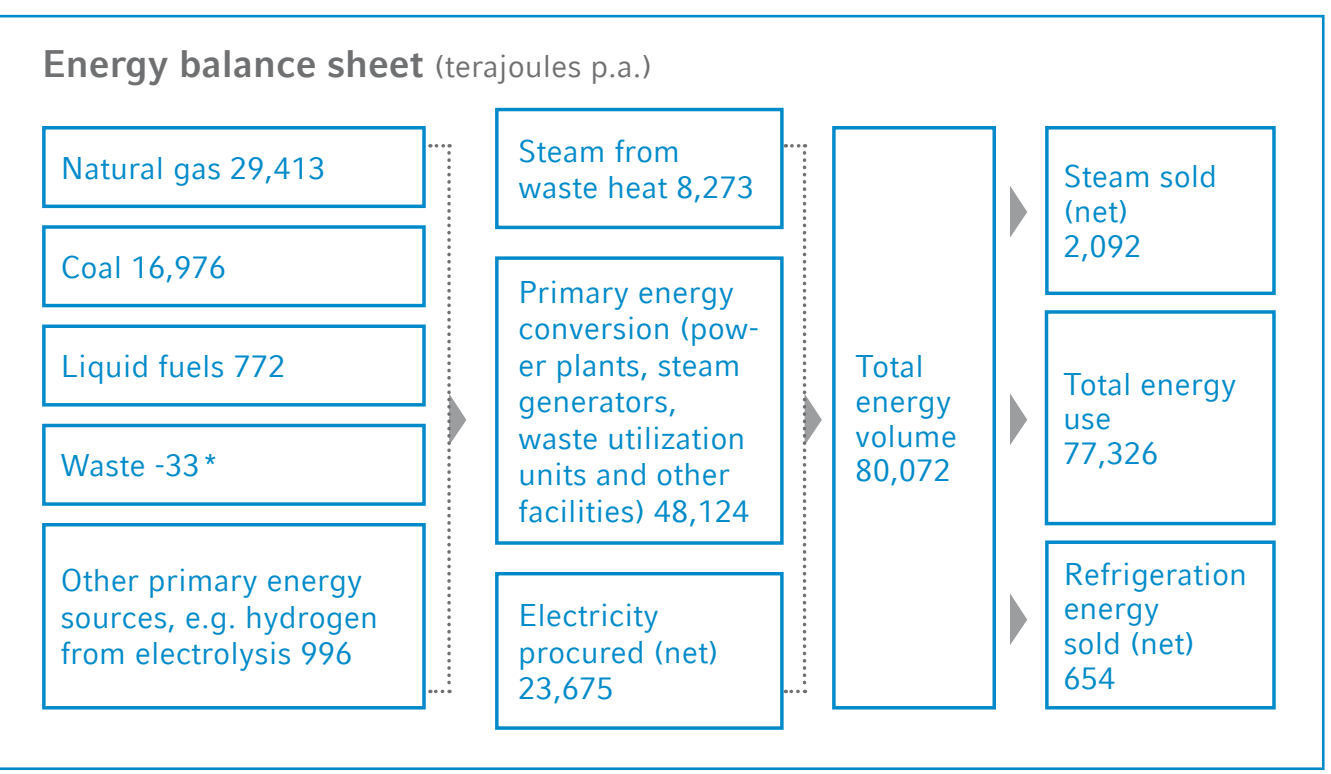

* More energy-generating waste was transferred to third parties than was used as heat sources and recycled within the Group. Therefore, the reported net volume of waste is negative.

Although the economic downturn was the dominant factor behind the development in energy consumption in 2009, we are vigorously pursuing the goal of efficient energy use. To this end, we are developing innovative processes, investing in modern plants, and implementing energysaving measures. Thus, the Bayer Climate Check, which was developed by Bayer Technology Services (BTS), identified potential energy savings of around 10 percent at the plants reviewed (see the Focus Issue Climate Protection on page 45). Building on the Climate Check, Bayer MaterialScience, Bayer Business Services and BTs have developed an innovative energy efficiency management system (STRUCTеse ${ }^{\circledR}$ ) to sustainably implement the energy-saving measures identified. BTS is also marketing the Bayer Climate Check to external companies.

Currenta has also effected numerous improvements in its waste incineration plants and improved efficiency in its energy generation. Considerable savings in fossil fuels have been achieved along with simultaneous reductions in $\mathrm{CO}_{2}$ emissions. Alone due to upgrades to the central waste air incineration plant at the Dormagen site, Currenta is reducing annual $\mathrm{CO}_{2}$ emissions by 30,000 metric tons. Natural gas consumption in this facility has been cut by almost one third by using modern incineration technology.

Many of these measures will be reflected in the energy consumption balance and the level of greenhouse gas emissions in coming years.

\section{Responsible use of water resources}

Drinking water is a resource that is already in short supply in many regions of the world. By developing and promoting solutions for the efficient and responsible consumption of water, Bayer is committed to conserving water as a raw material (see also the Sustainable Development Report 2008 on page $42 \mathrm{ff}$.). We also aim to use our products to make a real contribution to efficient water management and water pollution control worldwide.

\section{0 percent}

Use of modern incineration technology saves around 30 percent of natural gas. 
Progress reporting on the CEO Water Mandate of the UN Global Compact

Bayer will continue to support the UN Global Compact's CEO Water Mandate initiative signed at the end of 2008. We will therefore be working with our stakeholders to develop sustainable strategies for water use, implementing appropriate solutions and reporting on the progress made.

The actions listed provide an overview of how Bayer is implementing the CEo Water Mandate and of the results the Group was able to achieve during the reporting year:

- A new wastewater treatment plant has commenced operation at Bayer CropScience in Dormagen, Germany (see page 95).

- A Wastewater Recycling Tool developed by Bayer Technology Services is being used to estimate the economic benefits of and technical options for efficient water use.

- Development and testing of the Bayer Resource Efficiency Check from BTs, which can be used to perform an overall analysis of water consumption and other production-critical resources, thus enabling steps to be identified to minimize consumption (see page 90)

- Bayer CropScience is working in international partnerships on the development of droughtresistant strains of cotton and wheat with reduced susceptibility to stress resulting from a lack of water and heat damage (see page $45 \mathrm{f}$.).

- Bayer CropScience is running a "direct seeding" program for rice in Indonesia which may increase yields as well as reducing water use and greenhouse gas emissions (see page 39).

- At its production site in South Charleston in the United States, Bayer MaterialScience has optimized the wastewater treatment process in its polymer production facilities. This has reduced the wastewater volume and realized a potential annual cost reduction of us\$100,000.

- As part of Bayer's support for the Chair in Sustainable Development at Tongji University in China, work is under way on projects for the treatment of wastewater from the cassava bio-ethanol production process. This process was generating strongly polluted wastewater due to a lack of process technologies. The wastewater is now being treated using a new patented anaerobic process.

Further performance indicators for trends in water consumption and discharges into water can be found in this "Ecology" section on page $95 \mathrm{f}$.

In 2009, water consumption within Bayer fell by a total of 7.5 percent, primarily due to the drop in production, to a level of 1.11 million cubic meters per day. Over the year, the Group used 407 million cubic meters of water. The vast majority (80 percent) of the water used by Bayer is once-through cooling water (this figure includes losses due to evaporation). This water is only heated and does not come into contact with products. It can therefore simply be fed back into the natural water cycle.

Net water intake by source

\begin{tabular}{lrrrrr} 
& 2005 & 2006 & 2007 & 2008 & 2009 \\
\hline Water use (million m/d) & 1.24 & 1.20 & 1.23 & 1.20 & 1.11 \\
\hline- Proportion from surface water (percent) & 54 & 53 & 57 & 58 & 58 \\
\hline $\begin{array}{l}\text { - Proportion from bore holes/springs } \\
\text { (percent) }\end{array}$ & 35 & 35 & 32 & 32 & 32 \\
\hline $\begin{array}{l}\text { - Proportion from public drinking water } \\
\text { supplies (percent) }\end{array}$ & 2 & 2 & 2 & 1 & 1 \\
\hline $\begin{array}{l}\text { - Proportion from other sources, } \\
\text { generally rainwater (percent) }\end{array}$ & 9 & 9 & 9 & 9 & 9 \\
\hline
\end{tabular}


The Group endeavors to recycle water that is directly involved in manufacturing processes. Bayer Technology Services has developed a range of technologies that can treat process water and make it suitable for repeated reuse within technical cycles. The Wastewater Recycling Tool can be used to calculate the economic benefits and technical options for water reuse for each individual plant.

\section{Material use and resource efficiency}

The sustainable management of scarce natural resources is an important task for the future. Rising prices and falling availability of raw materials and energy make resource efficiency and corresponding process and product innovations a critical competitive factor. Bayer regards technological solutions as a key factor in confronting these important challenges, the goal of which is to make economic development independent as far as possible of resource consumption.

Our production-specific procurement activities, like production itself, are organized on a subgroup-specific basis in light of the diverse nature of our business activities.

Within a global production network comprising internal sites and contract manufacturing facilities, the Product Supply function within the Bayer HealthCare subgroup (Bнс) manages the entire supply chain from raw material procurement through production to product delivery. A large number of the active substances required by BHC's Bayer Schering Pharma division are

\section{Energy efficiency in the Dormagen water tower}

An innovative concept from Currenta's Water Supply Department is creating flexibility in terms of supply pressure, thus creating leeway for further energy optimization projects.

A water tower traditionally performs two functions: first, it provides a backup water supply for emergencies, and second, the column of water present is a determining factor in the network pressure level at the foot of the water tower.

Currenta has succeeded in decoupling the water tower at CHEMPARK Dormagen from the pressure in the process water system. Frequency inverters make it possible to regulate network pressure in line with requirements. The innovative feature of this decoupling process is that it enables both a reduction in the energy consumption of the process water supply (e.g. by adjusting the pressure in the system) and the full retention of the reserves in the water tower. manufactured internally. The starting materials for the production of these active substances are generally procured from external suppliers. To prevent supply bottlenecks and to mitigate major price fluctuations, BHC generally purchases starting materials and intermediates not produced internally both under global contracts and from a number of suppliers BHC has certified and approved. For the Consumer Care Division, we produce certain active substances such as acetylsalicylic acid and clotrimazole internally within the Group. The principal raw materials we purchase from third parties are naproxen, citric acid, ascorbic acid and other vitamins, as well as paracetamol.

Bayer CropScience procures most of its raw materials for the manufacture of crop protection agents externally. These include inorganic basic chemicals such as hydrochloric acid, sodium hydroxide and sulfuric acid, as well as organic fine chemicals and solvents.

The basic raw materials for our Bayer MaterialScience (BMS) products are petrochemical feedstocks such as benzene, toluene and phenol or sodium chloride. In an average business year with a procurement volume of approximately €7.5 billion, BMS purchases petrochemical raw materials worth roughly $€ 2.5$ billion, with the primary feedstocks broken down approximately as follows (in kilotons [kt]): $600 \mathrm{kt}$ of benzene, $800 \mathrm{kt}$ of phenol, $800 \mathrm{kt}$ of propylene and $230 \mathrm{kt}$ of toluene. We obtain these on the procurement markets, generally under long-term contracts. The operation of our production facilities also requires large amounts of energy, mostly in the form of electricity or steam. Energy costs therefore constitute a significant block of costs for the 
Bayer MaterialScience business. To minimize the price fluctuation risk, we aim for a balanced diversification of fuels for steam production. When purchasing power to cover requirements beyond what we produce in our own power plants, we aim for a mix of short-term purchases on the spot market and long-term purchases of forward products.

Bayer Technology Services is currently developing a methodology that can be used to perform a holistic analysis of all production-relevant resources such as energy, water and raw materials and that will indicate steps that can be taken to minimize consumption. This Resource Efficiency Check, which was initiated as part of the Bayer Sustainability Program, is based on the method used for the Bayer Climate Check and will be tested and verified in pilot projects in 2010. The check will in the future be used in production processes and reprocessing procedures to identify potential savings, increase resource efficiency and limit emissions and waste. This will enable process-oriented optimization to be achieved in procedures to increase yields and prevent wastage of starting materials and loss of products, as well as in recycling, the utilization of by-products, and wastewater or waste air treatment.

\section{Recycling}

For a large proportion of our end products, such as pharmaceuticals and crop protection agents, legal requirements make reclamation and recycling impossible. In order to minimize material use and waste volumes to the maximum extent possible, Bayer strives wherever technically feasible and justifiable in terms of cost to reuse materials or divert them to other processes. At Bayer the percentage of packaging that is recycled is not recorded for the whole Group. The range of products is very heterogeneous and subgroup-specific owing to the structure of the Group. For this reason, packaging types and materials can vary considerably (from bulk to blister packs). National recycling programs and establishments are also correspondingly varied, as are the legal requirements in the countries in which we sell our products.

\section{Team solution for saving and recycling}

A cross-subgroup team has shown how the world economic crisis can be used as an opportunity to achieve sustainable success. Bayer HealthCare (BHC) requires about 100,000 liters of acetonitrile a year. This is used as a solvent in active substance production. When acetonitrile became scarce as a result of the crisis - a development that affected all Bayer subgroups - a team set about searching for ways of using the product more sparingly and recycling used materials. The team consisting of experts from BHC, Bayer CropScience, Bayer Business Services, Bayer Technology Services and Currenta was successful: at BHC, the ability to supply was fully maintained and the work in Research \& Development was safeguarded. The experts from the Supply Center in Bergkamen made an important contribution: the employees at the recycling facility there developed a method for recycling used acetonitrile using existing systems. The recycled product is approved for use in analytical procedures registered with the authorities.
In many production processes, we employ technologies that are used to recycle specific materials. For example, we reprocess solvents by distillation and feed them back into processes. The German pharmaceuticals production sites in Bergkamen and Wuppertal-Elberfeld have been working together closely in this area for the past three years. Bergkamen recycles the solvent tetrohydrofuran (THF) for the Wuppertal-Elberfeld site. Recycling THF is more cost-effective and less time-consuming than manufacturing it. Similarly, non-recyclable solvents are used to generate energy at both production sites. At the Bergkamen site in Germany, Bayer HealthCare ( $\mathrm{BHC}$ ) binds iodine released during the incineration of waste from $x$-ray contrast medium production and extracts it as an iodide solution that can be marketed further.

An example of major technical advances in recycling is Bayer MaterialScience's method of hydrochloric acid electrolysis using an oxygen depolarized cathode, which makes it possible to recover 
chlorine from hydrochloric acid, thus saving raw materials and energy. This technology is being applied at the Brunsbüttel site in Germany and at the Shanghai site in China. Bayer MaterialScience has developed a polycarbonate mixture containing recycled polycarbonate production waste (known as post-industrial waste); this is being marketed under the name Levblend ${ }^{\circledR} .400$ metric tons have already been used in the automotive industry for non-safety-critical components. The Bayblend ${ }^{\circledR}$ product group constitutes a further example of conscientious resource use. Shredded water bottles (known as post-consumer waste material) are used as a constituent in Bayblend ${ }^{\circledast}$ FR 610, which is used primarily in the IT industry.

We use the BayCare platform to inform customers of Bayer MaterialScience how Bayer products can be disposed of or recycled in an environmentally friendly manner after use. At the Map Ta Phut site in Thailand, Bayer MaterialScience has established a program in which transportation bags (known as Big Bags) can be taken back from our customers and reused. After use, residues of the chemicals transported are removed from the transportation bags in a special process and the bags are then reused. Reusing the Big Bags resulted in savings of 16,955 new Big Bags in 2009. Warnings on the bags help to prevent them from being used for other purposes by our customers.

At the CHEMPARK sites, Currenta is responsible for organizing recycling: at these locations, waste is collected, sorted and offered on the market for further use. During the reporting period, the service company was able to improve the reclamation of recyclables from electronic scrap and use a new cable recycling machine to achieve a significant increase in the range of recyclable scrap cables.

\section{Protecting biodiversity}

The United Nations designated 2010 as the Year of Biodiversity. Bayer expressly supports the goals of the Convention on Biological Diversity (СBD), which aims to maintain biodiversity and ensure its sustainable use.

For Bayer CropScience (BCS), maintaining biodiversity and healthy agricultural ecosystems is the basis for sustainable agriculture. We have thus devised strategies to protect the diversity and variety of life. These concern research and development, solutions to make plants healthier, assistance in tackling invasive species and measures to promote integrated crop management. BCs is helping farmers to achieve higher productivity on areas that are already in agricultural use. This prevents natural habitats from being turned into cultivable land.

Bayer is involved in biodiversity projects at a whole host of locations. For example, since 2005 Bayer CropScience has been working together in São Paulo in Brazil with partners such as the local Environment Ministry and a humanitarian organization to promote biodiversity in the Taquara Branca microbasin. The goals are shoreline reforestation, the creation of ecological corridors for species of wild animals and the

\section{Promotion of biodiversity and creation of new habitats}

Protecting biodiversity will be one of the main challenges of the next few decades. Already today, agri-environmental measures are subsidized both at state and also E.U. level. Preserving biodiversity will come even more into focus in the future.

Bayer CropScience and the Foundation for the Preservation of the Rhine Culture Landscape (Stiftung Rheinische Kulturlandschaft) have signed a collaboration agreement to preserve rare arable weed species as part of the International Year of Biodiversity. We are supporting the project financially and applying our own extensive expertise: at eight trial farms belonging to Bayer CropScience in Germany, particularly rare and threatened species are reproduced and their seeds are stored for later sowing across suitable areas of land. We are thus demonstrating that modern cultivation management can coexist with state-of-the art biodiversity within the realms of sustainable agriculture. Location-specific flower strips up to 1,000 square meters in size have been laid out at eight test sites. The flower strips are an impressive example of how farmers will be able to meet future legal demands for agrienvironmental measures. 
qualification of young people to perform social activities related to environmental protection. Bayer CropScience is also supporting the U.s. nature conservation organization "Ducks Unlimited" in helping to create refuges for waterfowl in the prairies of North America. Under a fiveyear initiative, new seed varieties for winter wheat are to be developed to create better breeding conditions for waterfowl as a result of the increased cultivation of winter wheat.

Through an internal approval procedure we exclude the possibility that new production sites are set up in areas that are protected by statutory requirements of the countries concerned with respect to natural characteristics, biodiversity or similar factors. In every case, the stipulated minimum distances to protected areas are complied with. To make more precise statements about our existing production sites, we aim from 2010 to record these in stages in our new site register. In order to limit the total area of land use in general, we are committed to land recycling, e.g. by renaturizing unused sites in the CHEMPARK locations.

\section{Greenhouse gas emissions}

We report greenhouse gas emissions in accordance with the Greenhouse Gas (GHG) Protocol. This involves presenting emissions over prior years in a portfolio-adjusted format. During the reporting period, we acquired a nitric acid plant which is being operated by a third party in Baytown, United States. In accordance with the GHG Protocol, the data from the previous years were adjusted accordingly. At the Institute site in the United States, reporting in 2009 was switched to the financial control approach specified in the GHG Protocol. The prior-year figures have been adjusted accordingly.

In 2009, the total greenhouse gases reported in accordance with the GHG Protocol fell by 6.5 percent from the previous year. The drop in direct emissions was primarily due to cuts in production owing to economic factors and process engineering measures. Changes due to the economic circumstances also resulted in reduced indirect greenhouse gas emissions caused by the generation of electricity and heat by external suppliers. This drop in emissions was almost balanced by new conversion factors specified by the International Energy Agency (IEA) for $\mathrm{CO}_{2}$ emissions linked to energy consumption in Germany.

\begin{tabular}{lccccc}
\hline Greenhouse gas emissions * & & & & & \\
& 2005 & 2006 & 2007 & 2008 & 2009 \\
\hline $\begin{array}{l}\text { Direct greenhouse gas emissions ** } \\
\text { (million metric tons of } \mathrm{CO}_{2} \text { equivalents } \\
\text { p.a.) }\end{array}$ & 5.59 & 5.71 & 5.59 & 5.09 & 4.57 \\
\hline $\begin{array}{l}\text { Indirect greenhouse gas emissions } \\
\left(\begin{array}{l}\mathrm{CO}_{2} \text { only) } \\
\left.\mathrm{CO}_{2}\right)\end{array}\right.\end{array}$ & 3.52 & 3.67 & 3.71 & 3.57 & 3.53 \\
\hline $\begin{array}{l}\text { Total greenhouse gas emissions } \\
\text { (absolute) (million metric tons of } \mathrm{CO}_{2} \\
\text { equivalents) }\end{array}$ & 9.11 & 9.38 & 9.30 & 8.66 & 8.10 \\
\hline
\end{tabular}

* Portfolio-adjusted in accordance with the GHG Protocol. The acquisition of a nitric acid plant and the inclusion of greenhouse gases from the Institute site in the United States as part of our validation resulted in changes compared with the Sustainable Development Report 2008 (see text for explanation).

** Composition of direct greenhouse gas emissions in 2009 (in $\mathrm{CO}_{2}$ equivalents): 80.0 percent $\mathrm{CO}_{2}, 19.6$ percent nitrous oxide $\left(\mathrm{N}_{2} \mathrm{O}\right)$, just under 0.3 percent partially fluorinated hydrocarbons, 0.1 percent methane

*** Typically, $\mathrm{CO}_{2}$ in incineration processes accounts for over 99 percent of all greenhouse gas emissions. Therefore, when determining indirect emissions, our calculations are limited to $\mathrm{CO}_{2}$. 
In spite of the significant reduction of around 32 percent in absolute greenhouse gas emissions already achieved between 1990 and 2005, we have set ourselves further ambitious targets in all three subgroups.

\section{Targets for the reduction of greenhouse gas emissions}

\section{Global greenhouse gas emissions from 2005 to 2020}

Bayer MaterialScience

Reduction of greenhouse gas emissions per metric ton of sales product (excl. $\mathrm{NaOH}, \mathrm{HCl}$, trade products)

\begin{tabular}{l|l}
\hline $\begin{array}{l}\text { Bayer HealthCare } \\
\text { Reduction of greenhouse gas emissions }\end{array}$ & -5 percent, absolute \\
\hline $\begin{array}{l}\text { Bayer CropScience } \\
\text { Reduction of greenhouse gas emissions }\end{array}$ & -15 percent, absolute \\
\hline
\end{tabular}

$€ 1$ billion in investments in climate-related research, development and products from 2008 to 2010

Maintenance of Bayer Group greenhouse gas emissions at the 2007 levels until 2020 according to current estimates and despite production growth

The absolute emissions for each subgroup and the specific emissions for Bayer MaterialScience are shown in the table below. The service companies Bayer Technology Services and Bayer Business Services do not have their own climate targets due to their limited emissions. These are summarized under "Other."

Greenhouse gas emissions for subgroups and service companies (total direct and indirect emissions in million metric tons of $\mathrm{CO}_{2}$ equivalents)

\begin{tabular}{|c|c|c|c|c|c|c|}
\hline & 2005 & 2006 & 2007 & 2008 & 2009 & $\begin{array}{c}\text { Target for } \\
2020\end{array}$ \\
\hline BMS & 5.25 & 5.94 & 5.55 & 5.06 & 4.83 & - \\
\hline $\mathrm{BHC}$ & 0.59 & 0.58 & 0.57 & 0.56 & 0.54 & 0.56 \\
\hline $\mathrm{BCS}$ & 1.21 & 1.15 & 1.18 & 1.20 & 1.09 & 1.03 \\
\hline Other* & 0.02 & 0.02 & 0.02 & 0.02 & 0.02 & - \\
\hline Currenta ** & 2.04 & 1.69 & 1.98 & 1.82 & 1.62 & - \\
\hline Bayer Group & 9.11 & 9.38 & 9.30 & 8.66 & 8.10 & 9.30 \\
\hline $\begin{array}{l}\text { Specific greenhouse gas } \\
\text { emissions for BMS (metric } \\
\text { tons of } \mathrm{CO}_{2} \text { equivalents per } \\
\text { metric ton of product)*** }\end{array}$ & 1.18 & 1.21 & 1.07 & 1.05 & 1.16 & 0.89 \\
\hline
\end{tabular}

* Total greenhouse gas emissions for the service companies Bayer Technology Services and Bayer Business Services

** The emissions reported for Currenta are attributable to the provision of energy to other companies at the CHEMPARK sites.

*** The by-products sodium hydroxide solution and hydrochloric acid, which occur during production, are not included in the production volume because they will in the future occur in much smaller amounts thanks to measures aimed at enhancing energy efficiency. Trade products are also not included. 


\section{Emissions trading}

In Europe, Bayer is involved in European emissions trading by way of its own power plants which are used to generate energy. For this purpose, emissions allowances for a total of 2.3 million metric tons of $\mathrm{CO}_{2}$ were required for 11 plants in 2009 .

In the United States, Bayer Corporation has been a voluntary participant in emissions trading on the Chicago Climate Exchange (CCX) since 2003 with several production facilities, formulating plants and administrative centers. There, Bayer has undertaken to reduce greenhouse gas emissions by a total of 6 percent (based on the average for the years 1998 to 2001) between 2003 and 2010. This target has been met since the end of 2008 .

\section{Air emissions}

Emissions of ozone-depleting substances (ODS) increased in 2009 by 2.15 percent over the previous year. Despite this development, we were able to meet our target of limiting the emission of ODS to a maximum of 20 metric tons per year. The biggest increases were seen at the Bayer CropScience site in Vapi, India, and at the CHEMPARK site in Dormagen, Germany. In Vapi, production of an important intermediate was increased, resulting in increased emissions of tetrachloromethane. The increase in Dormagen is attributable to a new, more precise waste air measurement process.

\section{Emissions of ozone-depleting substances* (metric tons p.a.)}

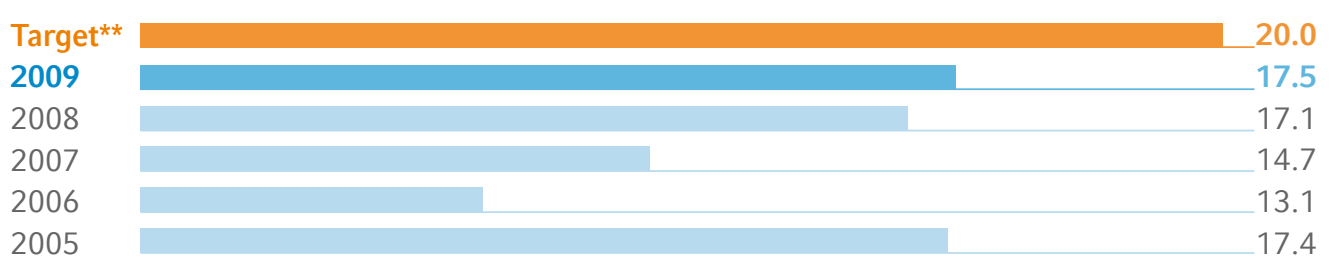

* In CFC-11 equivalents

** Target to be achieved by 2010 based on 2005 figures

The volume of volatile organic compounds (VOC) fell by about 18 percent compared to the previous year. At the Vapi site in India, Bayer CropScience (BCS) sold a production unit which was responsible for a large proportion of Group-wide voc emissions. In Ankleshwar in India, the amount produced was almost halved, while the Widnes site in the United Kingdom was finally shut down and production transferred to other BCs locations. vOc emissions per metric ton of sales product fell to just under 0.3 kilograms. We intend to achieve our target of reducing specific voc emissions to a maximum of 0.25 kilograms per metric ton by optimizing waste air treatment at the BCs site in Vapi; this optimization is to be implemented in steps up to 2015.

VOC emissions (1,000 metric tons p.a.) 


\section{VOC emissions (kg per metric ton of sales product)}

$\begin{array}{lr}\text { Target } & 0.25^{*} \\ 2009 & 0.2979 \\ 2008 & 0.3160 \\ 2007 & 0.2708 \\ 2006 & 0.2832 \\ 2005 & 0.3536\end{array}$

* Target to be achieved by 2010 based on 2005 figures

Carbon monoxide, nitrogen oxides, sulfur oxides and particulate matter from production and incineration processes are also important air emissions. We were able to achieve reductions in all three gaseous emissions.

Other important air emissions (1,000 metric tons p.a.)

\begin{tabular}{lccccc} 
& $\mathbf{2 0 0 5}$ & $\mathbf{2 0 0 6}$ & $\mathbf{2 0 0 7}$ & $\mathbf{2 0 0 8}$ & $\mathbf{2 0 0 9}$ \\
\hline CO & 1.7 & 2.2 & 2.0 & 1.7 & 1.4 \\
\hline NOx & 4.3 & 4.0 & 4.0 & 3.9 & 3.5 \\
\hline SOx & 4.5 & 3.8 & 3.6 & 3.2 & 2.8 \\
\hline Particulates & 0.3 & 0.2 & 0.2 & 0.2 & 0.2 \\
\hline
\end{tabular}

\section{Emissions into water}

Group-wide, Bayer released 76 million cubic meters of wastewater during the reporting period. This includes wastewater from production and from waste air treatment facilities, contaminated cooling water from recooling plants, and sanitation wastewater, as well as rainwater that came into contact with chemicals and fuels such as gas oils, bitumen or lubricants. Once-through cooling water, which accounts for by far the largest proportion of total water requirements, is not included. Because this is only heated during use and does not come into contact with products, it is returned to water bodies after cooling without further treatment. 67 percent of the polluted wastewater was treated in a wastewater treatment plant. Bayer uses high-performance treatment and monitoring technologies for this purpose. We also offer high-efficiency treatment facilities and effective wastewater management to our customers. These facilities utilize a combination of physical, chemical and biological treatment processes to permit a high level of treatment performance and environment friendliness.

We are continuously working on improving wastewater treatment methods: among other measures, Bayer CropScience commissioned a new wastewater treatment facility at its formulation plant in Dormagen, Germany, in 2009, with environmental experts from Currenta acting as consultants. This plant reduced absorbable organic halogen compound (AOX) levels in the process water by over 20 percent.

Phosphorus emissions into water fell by approximately 5 percent in 2009. The two major North American production sites in Baytown and Kansas City had a particularly strong impact on this reduction. In Baytown, the largest phosphorus emitter in the MaterialScience subgroup, 2009 saw a process modification in Makrolon ${ }^{\circledR}$ production, as a result of which the compounds containing phosphorus are now largely no longer used. In Kansas City, production of a phosphoruscontaining active substance was discontinued by Bayer CropScience. 
Absolute nitrogen emissions fell by 4.6 percent from the previous year's level. This was essentially due to the reduced capacity utilization of the production facilities. Because the volume of products sold fell by 13 percent, the specific amount of nitrogen increased in 2009 to 0.074 kilograms per metric ton of sales product. The projects "new cascade biology" and "improvement of nitrification" at the German CHEMPARK sites in Leverkusen and Dormagen had a positive impact. These have resulted in the treatment plants breaking down an additional 300 metric tons of nitrogen annually.

The specific volume of total organic carbon (Тос) fell in 2009 to 0.155 kilograms per metric ton of sales product. In absolute terms, Toc emissions fell by approximately 15.4 percent from the previous year. In this case, production cuts made themselves felt, as did the change in the way loads are accounted for at the site in Caojing, China. It is only since 2009 that Toc contents following appropriate wastewater treatment have been reported here (before this, only untreated water pollution levels were reported).

The volumes of heavy metals and inorganic salts emitted fell by 13.4 percent and 10.5 percent respectively due to economic factors.

Emissions into water (absolute)

\begin{tabular}{lccccc} 
& 2005 & 2006 & 2007 & 2008 & 2009 \\
\hline $\begin{array}{l}\text { Total phosphorus - inorganic and } \\
\text { organic (1,000 metric tons p.a.) }\end{array}$ & 0.74 & 0.81 & 0.99 & 0.78 & 0.74 \\
\hline $\begin{array}{l}\text { Total nitrogen - inorganic and } \\
\text { organic (1,000 metric tons p.a.) }\end{array}$ & 0.58 & 0.73 & 0.68 & 0.67 & 0.64 \\
\hline $\begin{array}{l}\text { Heavy metals } \\
(1,000 \text { metric tons p.a.) }\end{array}$ & 0.0116 & 0.008 & 0.0089 & 0.0104 & 0.009 \\
\hline $\begin{array}{l}\text { Inorganic salts } \\
(1,000 \text { metric tons p.a.) }\end{array}$ & 797 & 843 & 825 & 812 & 726 \\
\hline $\begin{array}{l}\text { TOC* } \\
(1,000 \text { metric tons p.a.) }\end{array}$ & 1.49 & 1.49 & 1.77 & 1.59 & 1.35 \\
\hline $\begin{array}{l}\text { COD** chemical oxygen demand } \\
(1,000 \text { metric tons p.a.) }\end{array}$ & 4.47 & 4.47 & 5.31 & 4.77 & 4.05 \\
\hline
\end{tabular}

* Total organic carbon

${ }^{*}$ Calculated value based on TOC figures (TOC $\times 3=$ COD)

Emissions into water ( $\mathrm{kg}$ per metric ton of sales product)

\begin{tabular}{lcccccc} 
& 2005 & 2006 & 2007 & 2008 & 2009 & Target* \\
\hline Nitrogen & 0.0596 & 0.0723 & 0.0642 & 0.0669 & 0.0737 & 0.0536 \\
\hline Total organic carbon (TOC) & 0.153 & 0.147 & 0.167 & 0.159 & 0.155 & 0.138 \\
\hline
\end{tabular}

* Target to be achieved by 2010 based on 2005 figures 


\section{Waste generation and disposal}

The total volume of waste generated fell by 15 percent in 2009 to 914,000 metric tons due to a drop in production resulting from the economic circumstances. However, some sites had larger relative quantities of production wastes than in the previous year due to changes in the product portfolio or due to their production plants not running at the appropriate capacity.

The volume of hazardous waste from production fell slightly, while the total volume generated, which includes hazardous production and construction waste, was above the previous year's level. The Bayer CropScience sites in Institute, United States, and Thane, India, accounted for the most substantial volumes of hazardous construction waste. In Institute, 22,800 metric tons was disposed of, this being generated when the methomyl plant (including piping) was demolished following an explosion and fire the previous year (see the Bayer Sustainable Development Report 2008). In Thane, an entire production plant was demolished.

\begin{tabular}{lccccc}
\hline Waste generated * (1,000 metric tons p.a.) & & & & \\
& 2005 & 2006 & 2007 & 2008 & 2009 \\
\hline Total waste generated & 760 & 649 & 928 & 1,077 & 914 \\
\hline Hazardous waste generated ** & 351 & 336 & 342 & 365 & 375 \\
\hline $\begin{array}{l}\text { Hazardous waste generated } \\
\text { in production }\end{array}$ & 221 & 234 & 275 & 305 & 302 \\
\hline
\end{tabular}

* Only waste generated by Bayer

** Definition of hazardous waste in accordance with the local laws in each instance

The specific volume of hazardous production waste has increased. Thus, hazardous production waste did not fall to the same degree as the volume of sales product. We have moved further away from the target we set ourselves of reducing the specific volume of hazardous production waste to below 2.5 percent per metric ton of sales product. In 2009, this value was 3.5 percent. This development has two reasons. First, a significant change in the product portfolio over the past few years has led to the generation of more hazardous waste: at Bayer HealthCare owing to the acquisition of Schering and at Bayer CropScience due to a considerable expansion of production activities. Second, the trend has intensified as the Bayer MaterialScience subgroup has recorded a sharp decline in volumes, which worsened the ratio between hazardous waste and volume of sales product. The changes in our product portfolio mean that we shall not achieve our target for the Bayer Group for 2010 either.

\begin{tabular}{|c|c|c|c|c|c|c|}
\hline & 2005 & 2006 & 2007 & 2008 & 2009 & Target* \\
\hline $\begin{array}{l}\text { Volume of hazardous } \\
\text { production waste (percent) }\end{array}$ & 2.28 & 2.32 & 2.59 & 3.05 & 3.47 & 2.5 \\
\hline
\end{tabular}

* Target to be achieved by 2010 based on 2005 figures

The environmentally friendly and legally compliant disposal of waste has a high priority at Bayer. The volume of recycled waste could be increased significantly. 


\begin{tabular}{lcccccc}
\multicolumn{2}{l}{ Waste disposed of* according to means of disposal } & & & \\
& 2005 & 2006 & 2007 & 2008 & 2009 \\
\hline $\begin{array}{l}\text { Total volume of waste disposed of } \\
\text { (1,000 metric tons p.a.) }\end{array}$ & 848 & 654 & 931 & 1,061 & 918 \\
\hline \begin{tabular}{l} 
Proportion removed to landfill (percent) \\
\hline Proportion incinerated (percent)
\end{tabular} & 52 & 44 & 48 & 45 & 40 \\
\hline $\begin{array}{l}\text { Proportion recycled (percent) } \\
\text { Waste that cannot definitively be }\end{array}$ & 18 & 28 & 23 & 28 & 31 \\
\hline $\begin{array}{l}\text { categorized according to one of the } \\
\text { above disposal methods (percent) }\end{array}$ & 1 & 3 & 3 & 3 & 1 \\
\hline
\end{tabular}

* Bayer serves as a certified waste disposal plant operator at various sites. At these locations, Bayer disposes not only of its own waste but also of waste from third parties (companies not belonging to the Bayer Group). There is therefore a somewhat larger amount of waste disposed of than Bayer has generated itself.

\begin{tabular}{lcccccc}
\hline Hazardous waste * disposed of according to means of disposal & \\
& 2005 & 2006 & 2007 & 2008 & 2009 \\
\hline $\begin{array}{l}\text { Total volume of hazardous waste } \\
\text { disposed of (1,000 metric tons p.a.) }\end{array}$ & 351 & 336 & 342 & 365 & 375 \\
\hline $\begin{array}{l}\text { - Volume landfilled (1,000 metric } \\
\text { tons p.a.) }\end{array}$ & 211 & 134 & 101 & 81 & 89 \\
\hline $\begin{array}{l}\text { - Volume incinerated/recycled } \\
\text { (1,000 metric tons p.a.) }\end{array}$ & 140 & 202 & 241 & 284 & 286 \\
\hline
\end{tabular}

* Waste generated by Bayer only

Since April 1, 2010, regulations in Germany have stipulated the use of an electronic waste documentation procedure (eANV), which supersedes the previous paper-based process. Bayer Business Services has developed its own solution - evENTO $^{\circledR}$. This offers clear advantages for generators, carriers and disposal organizations. The application can be used quickly and efficiently by all participants in the process, since all reporting and disposition monitoring documentation is processed and stored electronically.

\section{Environmental incidents and transport accidents}

Bayer uses the term "environmental incidents" to cover incidents resulting in the release of substances into the environment. They are divided into two categories depending on the amount and nature of the substance, the potential hazard, the impact on residents and the scope of reporting in the media:

- Level 1 incidents are serious environmental events whose resultant costs, for example for repairs to plants, clean-up etc., are in excess of $€ 2$ million or that meet other relevant criteria.

- Level 2 incidents are, for example, significant environmental incidents whose resultant costs are in excess of $€ 100,000$ but less than $€ 2$ million or that meet other relevant criteria.

According to our internal voluntary commitment, we report even minor production releases: in the case of substances with a high hazard potential, we report quantities from 0.1 metric tons upwards. 


\begin{tabular}{ccccc}
\multicolumn{2}{c}{ Environmental incidents (number p.a.) } & & \\
\hline 2005 & 2006 & 2007 & 2008 & 2009 \\
\hline 3 & 8 & 3 & 9 & 13 \\
\hline
\end{tabular}

During the reporting period, there were 13 environmental incidents that were reportable according to Group-wide regulations. Of these, nine were level 1 environmental incidents and four were categorized as level 2.

Transport accidents according to means of transport (numbers p.a.)

\begin{tabular}{|c|c|c|c|c|c|}
\hline & 2005 & 2006 & 2007 & 2008 & 2009 \\
\hline Road & 2 & 6 & 9 & 8 & 8 \\
\hline Rail & 1 & 3 & 1 & 1 & 2 \\
\hline $\begin{array}{l}\text { Inland } \\
\text { waterways }\end{array}$ & 0 & 0 & 0 & 0 & 0 \\
\hline Sea & 0 & 0 & 0 & 1 & 0 \\
\hline Air & 0 & 0 & 0 & 0 & 0 \\
\hline Pipeline & - & 0 & 0 & 0 & 0 \\
\hline Total & 3 & 9 & 10 & 10 & 10 \\
\hline
\end{tabular}

We examined the absolute number of 10 transport accidents in relation to the number of transport movements completed in 2009 of 709,744. Around two thirds of the movements were systematically recorded internally, while for the remaining regions/countries, a qualified estimate was determined for 2009. Figures for these will be recorded more precisely in the future. Our analysis gave a rate of 0.14 transport accidents per 10,000 transport movements completed. This rate is more illustrative than the absolute number of transport accidents since, like the method used to present occupational injury rates, it presents the number of accidents as a proportion of the transport operations actually completed.

Unfortunately, even our extensive safety precautions and training procedures cannot entirely prevent environmental incidents or transport accidents occurring. In order to further increase transport safety, we implemented a new Group-level transport safety regulation in 2009. This regulation contains obligatory measures which will enable hazards to be prevented during the transportation of materials and products. It also documents the obligation to carefully analyze and evaluate any incidents and accidents so that appropriate steps can be taken to prevent a recurrence.

In addition, we target our transport service providers directly: the Bayer MaterialScience regional teams responsible for safety in transport and distribution conduct special health and safety training sessions for the logistics partners. Bayer HealthCare (BHC) had no transport accidents in 2009. BHC employs strict criteria when selecting service providers for European land transportation. Preferably, companies with their own equipment (temperature-controlled doubledecker vehicles with GPS /GSM) are used, thus avoiding the use of sub-contractors.

Bayer CropScience continued its training program on the safe handling and transportation of hazardous substances and goods in Asia. A procedure for the proper classification and packaging of samples was established that also supports the qualification of suppliers by BCs staff in these countries. 
As part of the continuous development of our safety management, we also updated our management approach to process and plant safety in 2009, which found expression in a new Group regulation. The first measures, e.g. training, will be implemented in 2010.

The tables below detail environmental incidents and transport accidents recorded at Bayer during the reporting year.

Environmental incidents in 2009

\begin{tabular}{|c|c|c|c|c|c|}
\hline & Plant & Date & $\begin{array}{l}\text { Environ- } \\
\text { mental } \\
\text { incident } \\
\text { level }\end{array}$ & $\begin{array}{l}\text { Personal } \\
\text { injuries }\end{array}$ & Description \\
\hline 1 & $\begin{array}{l}\text { BMS, Dormagen, } \\
\text { Germany }\end{array}$ & $\begin{array}{l}\text { January } \\
14,2009\end{array}$ & 1 & no & $\begin{array}{l}\text { Safety triggering of an ammonia } \\
\text { damping wall to prevent a phosgene } \\
\text { leak }\end{array}$ \\
\hline 2 & $\begin{array}{l}\text { Currenta, } \\
\text { Leverkusen, } \\
\text { Germany }\end{array}$ & $\begin{array}{l}\text { February } \\
22,2009\end{array}$ & 1 & no & $\begin{array}{l}\text { Due to a defect in a dosing system } \\
\text { in the waste air treatment facility, } \\
\text { a short-term leak occurred of a } \\
\text { reddish plume of waste air during } \\
\text { the incineration of iodine-containing } \\
\text { waste. }\end{array}$ \\
\hline 3 & BCS, Thane, India & $\begin{array}{l}\text { May 5, } \\
2009\end{array}$ & 2 & no & $\begin{array}{l}\text { Fire in an interim storage facility } \\
\text { containing } 108 \mathrm{~kg} \text { of BCS products }\end{array}$ \\
\hline 4 & $\begin{array}{l}\text { BCS, Kansas City, } \\
\text { United States }\end{array}$ & $\begin{array}{l}\text { May 25, } \\
2009\end{array}$ & 1 & $\begin{array}{l}1 \text { employee } \\
\text { hospitalized } \\
\text { for observa- } \\
\text { tion }\end{array}$ & $\begin{array}{l}\text { Excess pressure when cleaning a } \\
\text { vessel resulted in the release of a } \\
\text { cloud of vapor which also contained } \\
\text { constituents of hydrochloric acid } \\
\text { and sulfur dioxide. }\end{array}$ \\
\hline 5 & $\begin{array}{l}\text { BMS, Baytown, } \\
\text { United States }\end{array}$ & $\begin{array}{l}\text { June 17, } \\
2009\end{array}$ & 2 & no & $\begin{array}{l}\text { Release of carbon monoxide and } \\
\text { monochlorobenzene (MCB) in a } \\
\text { hydrochloric acid plant }\end{array}$ \\
\hline 6 & $\begin{array}{l}\text { BHC, Bergkamen, } \\
\text { Germany }\end{array}$ & $\begin{array}{l}\text { Septem- } \\
\text { ber 5, } \\
2009\end{array}$ & 1 & no & $\begin{array}{l}\text { Explosion caused by the spon- } \\
\text { taneous combustion of residual } \\
\text { aluminum alkyl }\end{array}$ \\
\hline 7 & $\begin{array}{l}\text { BMS, Brunsbüttel, } \\
\text { Germany }\end{array}$ & $\begin{array}{l}\text { Novem- } \\
\text { ber 25, } \\
2009\end{array}$ & 2 & no & $\begin{array}{l}\text { Release of less than } 1 \text { cubic meter } \\
\text { of } 20 \text { percent sodium hydroxide } \\
\text { due to a leakage in a storage vessel } \\
\text { caused by a defective seal }\end{array}$ \\
\hline 8 & $\begin{array}{l}\text { BMS, Dormagen, } \\
\text { Germany }\end{array}$ & $\begin{array}{c}\text { Novem- } \\
\text { ber } 27 \\
2009\end{array}$ & 1 & no & $\begin{array}{l}\text { Safety triggering of an ammonia } \\
\text { damping wall to prevent a phosgene } \\
\text { leak }\end{array}$ \\
\hline
\end{tabular}




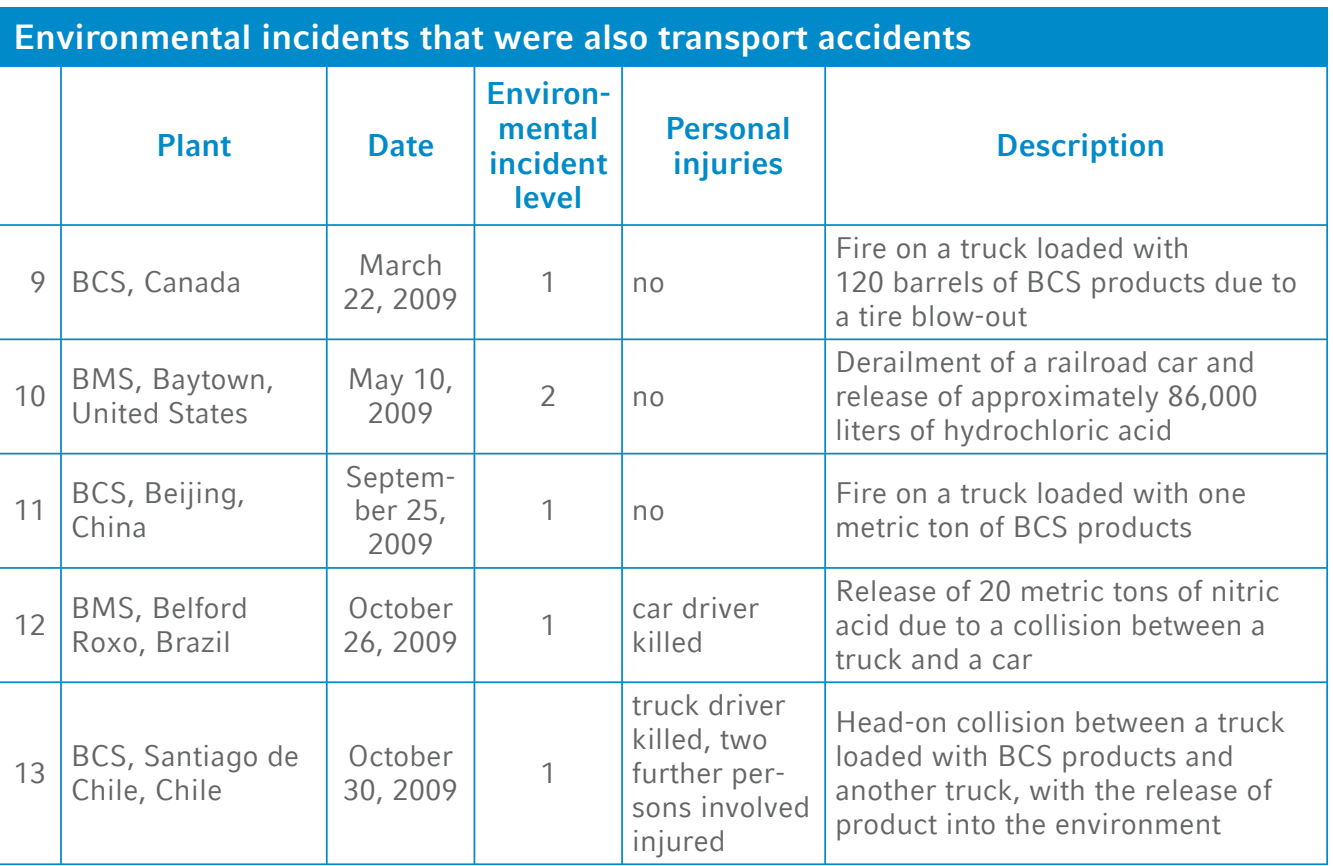

\begin{tabular}{|c|l|c|c|c|l|}
\hline \multicolumn{1}{|c|}{ Purely transport accidents in 2009} \\
\hline 1 & Plant & $\begin{array}{c}\text { Environ- } \\
\text { mental } \\
\text { incident } \\
\text { level }\end{array}$ & $\begin{array}{c}\text { Personal } \\
\text { injuries }\end{array}$ & \multicolumn{1}{|c|}{ Description } \\
\hline 1 & BCS, Canada & $\begin{array}{c}\text { March } \\
12,2009\end{array}$ & no & no & $\begin{array}{l}\text { Minor release of BCS product } \\
\text { approximately 10 liters) due to an } \\
\text { accident involving a truck loaded } \\
\text { with BCS products. }\end{array}$ \\
\hline 2 & $\begin{array}{l}\text { BMS, Foxhol, } \\
\text { Netherlands }\end{array}$ & $\begin{array}{c}\text { April 16, } \\
2009\end{array}$ & no & no & $\begin{array}{l}\text { Sealed but empty barrel with label- } \\
\text { ing for Desmodur (MDI) found in } \\
\text { Denderleeuw, Belgium. The barrel } \\
\text { had been lost due to inadequate } \\
\text { securing of the load. }\end{array}$ \\
\hline 3 & $\begin{array}{l}\text { BMS, Spring, } \\
\text { United States }\end{array}$ & $\begin{array}{c}\text { April 22, } \\
2009\end{array}$ & no & no & $\begin{array}{l}\text { Leaky barrel holding polyol contain- } \\
\text { ing MDI on a truck }\end{array}$ \\
\hline 4 & $\begin{array}{l}\text { BMS, Baytown, } \\
\text { United States }\end{array}$ & $\begin{array}{c}\text { Septem- } \\
\text { ber 15, } \\
2009\end{array}$ & no & two persons & $\begin{array}{l}\text { Excess pressure in a tanker } \\
\text { wagon with the release of steam; } \\
\text { no product released }\end{array}$ \\
\hline 5 & $\begin{array}{l}\text { BMS, Leverkusen, } \\
\text { Germany }\end{array}$ & $\begin{array}{c}\text { Septem- } \\
\text { ber 16, } \\
2009\end{array}$ & no & no & $\begin{array}{l}\text { Leakage during the road transporta- } \\
\text { tion of hydrochloric acid }\end{array}$ \\
\hline
\end{tabular}

WWW 107 UN Global Compact CEO Water Mandate I 108 Tongji University 109 BayCare platform | 110 Biodiversity | 111 Stiftung Rheinische Kulturlandschaft 112 Convention on Biodiversity | 113 Ducks Unlimited | 114 GHG Protocol | 115 IEA 116 Bayer Climate Program I 117 Chicago Climate Exchange 


\section{Product stewardship}

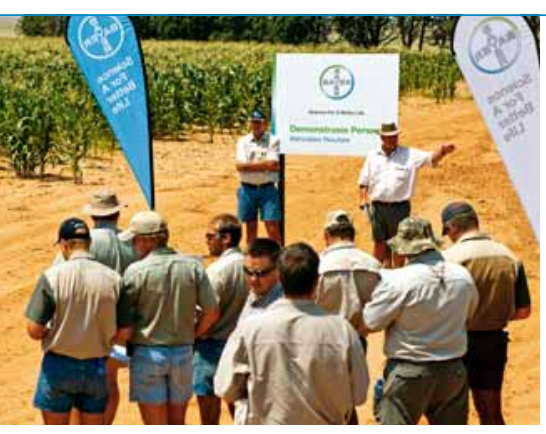

Product stewardship has a high priority for us. Our measures start with product development and extend across manufacture

right through to application. We also train farmers to handle crop protection agents safely, such as here at the Farmers' Day in South Africa.

\section{In focus}

Top priority is given to the safety and compatibility of our products

Risk assessment according to international standards and regulations

Well-founded risk analysis for the use of future-oriented technologies

Comprehensive product information as the basis for responsible and proper use of our products

\section{Bayer assigns maximum priority to meeting its responsibility for the environ-} ment and to maintaining the health and safety of everyone who comes into contact with our products. We take this responsibility very seriously, and check and monitor all Bayer products in applications known to us with respect to health, safety, environment and quality (HSEQ).

\section{Implementation of our Global Product Strategy}

To meet our responsibility conscientiously, we need to monitor products throughout their life cycle - from development through production to application and safe disposal. Since 1994, we have oriented the risk assessment of our products to the voluntary Responsible Care ${ }^{\circledR}$ initiative of the chemical industry and its revised Responsible Care Global Charter - a document we signed in 2006. The Global Product Strategy (GPS) is part of this charter.

The aim of the GPS - based on an initiative of the International Council of Chemical Associations (ICCA) - is to improve and standardize the level of product stewardship in the chemical industry, particularly in emerging and developing countries. In 2009, we developed our own global product strategy in accordance with the ICCA guidelines that is particularly relevant for chemicals in the market. The strategy is implemented in a four-stage process. In this context, certain products are continuously assessed with regard to new findings, their hazard potential and possible risks, and a suitable risk management policy is implemented that includes communication of risks.

\section{Data registration and substance labeling}

For all materials used by Bayer - be they raw materials, intermediates or end products - relevant safety information is available throughout the Bayer Group in product databases and in the form of safety data sheets. All subgroups possess suitable data acquisition systems for product information enabling them to meet the respective product safety and information obligations. We update the acquisition systems whenever this is necessitated by new statutory requirements.

Bayer HealthCare (BHC) is expanding its databases worldwide to further improve the accessibility of environmental, safety and substance data. This should enable new statutory requirements to be satisfied at short notice. In the context of its risk management process, BHC has also carried out risk analyses on such themes as label compliance. The analysis results have been incorporated into the "Regulatory Affairs" procedure governing the creation and revision of product labels and product information sheets. 
Bayer CropScience uses the "E-Label Server" to record data for all products marketed in Europe and parts of Asia and Africa. Furthermore, the External Adverse Incident Guideline governs the internal reporting channels worldwide for incidents involving the company's products. This enables risks to be identified and evaluated at an early stage and taken into account in product developments and market activities. The guideline has been revised and distributed worldwide throughout Bayer CropScience.

As a producer of high-quality materials, Bayer MaterialScience is subject to a wide variety of obligations concerning product safety and the publication of information. All relevant information is available worldwide through a product safety database. For external communications, Bayer MaterialScience is systematically supplementing its BayCare platform with information on industrial chemicals and adapting it to satisfy language requirements in the various regions, as the current examples in Brazil and China show.

\section{Statutory requirements for product evaluation: REACH and GHS}

Virtually all products manufactured by Bayer are subject to extensive legal requirements concerning the publication of information. In accordance with the European chemicals regulation REACH (Registration, Evaluation and Authorization of Chemicals), we successfully completed the pre-registration in 2008 of more than 800 substances that we either produce ourselves or import from outside the European Union. Bayer has thus created the necessary conditions for continued distribution of all these products. The Group-wide Directive on REACH Implementation, which was revised in 2009, stipulates the uniform procedure to be applied through 2018 so that REACH can be quickly implemented in all relevant areas: by the end of November 2010, we will draft registration dossiers for all substances that we produce or import in large volumes. Currenta's Analytics, Toxicology and Process and Plant Safety departments are supporting the subgroups in the creation of the registration dossiers and in substance testing. Bayer participates in consortia with its competitors to promote the exchange of data between companies and obviate the need for additional animal studies. The company obligates its suppliers to provide only substances that satisfy REACH so that we are safe on the raw material side as well. REACH will generally enable more substance information to be passed on in the product chain too, for example through expanded safety data sheets. This applies both to our suppliers and to Bayer itself.

Bayer also supports international efforts to introduce a uniform global system of classification and labeling for substances and preparations (mixtures). The Globally Harmonized System (GHS) for chemicals took effect in Europe at the beginning of 2009; its aim is to standardize the classification and labeling of chemicals. In 2010, the system was expanded to include China. Bayer's subgroups and service companies have formed a joint task force to coordinate all GHS activities throughout the Group. On behalf of this task force, Currenta's Process and Plant Safety Department represents Bayer in legislative bodies of the United Nations as regards GHS and transport issues. Bayer Technology Services has developed the logistics software LEXsY ${ }^{\circledR}$ LabelPrint to support the uniform, legally compliant and cost-effective implementation of GHs. Bayer MaterialScience has made this software the global standard. To ensure the GHS-compliant labeling of substances and mixtures as of November 30, 2010, and May 31, 2015, respectively, Bayer CropScience and Bayer HealthCare are working with Bayer Business Services to implement an SAP-EHS-based labeling program called Global Label Management (GLM). 


\section{International activities for the further development of scientific risk assessment}

Through participation in international associations and the support of political initiatives, Bayer makes an important contribution to the scientific risk assessment of chemicals. In connection with the Long-Range Research Initiative (LRI) set up by the international chemical associations, we enhance understanding about potential hazards posed by chemicals and optimize the scientific methods used to assess possible risks. Together with the Organisation for Economic Co-operation and Development (OECD), the European Center for Ecotoxicology \& Toxicology of Chemicals (ECETOC) and LRI, we are also active as regards the scientific validation of test methods, the further development of scientific risk assessment, and implementation in legal regulations.

Our association activities support important societal objectives: the goals set by the World Health Organization and by E.U. plans of action to improve health and the environment - and particularly children's health - are an example of this, as is the further development of human biomonitoring as an element of chemical risk assessment. Bayer is supporting a joint project of the German Environment Ministry and the German Chemical Industry Association (vCI) on method development. Currenta's Institute for Biomonitoring also plays an important role here through the association activities of its experts in such bodies as the German Research Society (DFG), the German Society for Occupational Health and Environmental Medicine (DGAUM) and the vCI. We also participate in organizations that focus on specific environmental aspects, such as the Society of Environmental Toxicology and Chemistry (SETAC) and the International Life Science Institute/Health and Environmental Sciences Institute (ILSI/HESI).

\section{Implementing the precautionary principle}

The precautionary principle is defined in Article 15 of the Rio Declaration of the United Nations Conference on Environment and Development (1992) and in the Communication from the European Commission. It is applied whenever there is sufficient evidence that people or the environment could suffer significant or irreversible damage, regardless of whether scientific certainty already exists. Bayer supports the application of the precautionary principle according to the stipulations given in the Communication from the European Commission. This means that the measures must be: proportionate, in other words satisfy the intended level of protection; applicable without discrimination, in other words comparable circumstances must not be treated in different manners; consistent with similar measures undertaken previously; and analyzed with respect to the costs and benefits associated with the application of the precautionary principle.

The measures undertaken are evaluated as soon as new scientific data are available for the particular circumstance.

\section{Animal studies for innovation and safety}

As a research-based company, we depend on animal studies to investigate the effects of our products on people, animals and the environment. Such testing is scientifically necessary and is also prescribed by law in the majority of cases. We have anchored in our "Policy on animal welfare and animal studies" the basic principle of using only as many animals as necessary to attain scientifically meaningful results. The principles also apply to external studies and are monitored by our Animal Protection Officer. 
Since 2005, Bayer has been a member of the European Partnership for Alternative Approaches to Animal Testing (EPAA), a joint initiative of the European Commission and industry. We support the EPAA's "3R" principle with the aim of "reducing" the number of experimental animals, "refining" experimentation methods and "replacing" animal studies with other methods. Furthermore, for many years we have been active in German and international projects aimed at developing alternatives to animal studies, and we participate in studies organized jointly by pharmaceutical companies and universities.

In 2009, Bayer scientists conducted studies with 171,251 animals (2008: 157,710) worldwide. In the vast majority of cases, these animals were used in the development of drug products; in other cases, they were used in the development of new animal health products, crop protection agents or industrial chemicals. Most (approximately 92 percent) of the animals used in testing in 2009 were rodents, such as rats and mice. Fish accounted for 3.8 percent of animals used in testing, and birds for 2.3 percent. The total share of dogs, cats and monkeys used in research was 0.6 percent.

The increase compared to 2008 was due to the growth in the use of mice, fish and birds. As a result of increased research efforts in the field of oncology we now require more mice to characterize new active substances, including in response to regulatory inquiries. The larger number of fish tested resulted from the rise in ecotoxicological studies stipulated by the regulatory authorities. The evaluation of promising approaches in the treatment of poultry has led to an increase in the number of corresponding animals tested.

New statutory guidelines worldwide promote the additional generation of data through animal studies to determine the safety of substances. The Protection of Animals Act specifies that only those animals expressly bred for testing purposes may be used in animal studies. This act explicitly allows exceptions for agricultural livestock and fish, as test animals are not bred in these species.

\section{Nanotechnology - an investment in the future}

For a research-oriented company like Bayer, nanotechnology is an important technology of the future. It is regarded as a key technology of the $21^{\text {st }}$ century and harbors tremendous innovation potential for a variety of economic sectors and user industries. Nanoscience offers us ways of gaining a much better understanding of phenomena at the atomic level. Through nanotechnology we are able to develop materials and components that offer completely new properties, functions and levels of performance. Nanotechnology has relevance throughout the Bayer Group and can contribute to sustainable product solutions in all areas of the company.

As nanotechnology is a relatively new technology, a sound, scientific risk analysis is particularly important to protect human health and the environment. Bayer is assuming a pioneering role in safety, particularly as regards activities with carbon nanotubes. A comprehensive Product Stewardship Program supports the safe handling of these materials - from production through processing and use to disposal - in all areas in which this technology is used.

We have summarized our principles for the handling of nanotechnology in the Bayer Position on Nanotechnology. We also support safety projects promoted by the German Ministry of Education and Research such as CarboSafe. We are working intensively on the international harmonization of terminology and characterization at the Iso level and on the drafting of toxicological test guidelines at OECD level. Furthermore, we foster a very close stakeholder dialogue with committees, associations, industry partners, customers, authorities, universities and the public.
Nanotechnology

Product Stewardship Program supports safe handling. 
Quality management

Extensive quality management activities in human and veterinary medicine

\section{Stringent drug safety requirements}

The manufacture of drug products and medical equipment is subject to stringent quality requirements and monitoring. The Global Pharmacovigilance unit of Bayer HealthCare pools all safety-relevant information on our medical products. This information is continuously updated and evaluated by experts. Bayer works closely with the responsible registration and oversight authorities at an international, national and regional level. These include the U.s. Food and Drug Administration (FDA), the European Medicines Agency (EMA) and the German Federal Institute for Drugs and Medical Devices (BfArM).

The Bayer HealthCare Compliance Management System describes measures aimed at permanently and continuously satisfying regulatory requirements for quality assurance in human and veterinary medicine. The observation of compliance standards is verified through systematic internal inspection both for all functions summarized as global clinical development and for production. These audits also include contract service providers and suppliers. Risks are systematically identified and assessed with the help of a risk management system. Deviations, infringements and quality deficiencies are analyzed on a case-by-case basis, and preventive or corrective measures undertaken. Countries and regions continuously receive support in observing compliance.

We continuously evaluate the benefit-risk profile of our pharmaceutical and medical products from their development until their registration and once they are being marketed. Within the scope of risk management at Bayer HealthCare, experts from various disciplines jointly evaluate the available data on a product so as to identify safety risks as early as possible and initiate measures aimed at improving understanding and at preventing or reducing the risk. These measures are summarized, for example, in risk management plans. Should adverse effects or other risks become known following the registration of a product, we immediately take steps to minimize the risks. These actions can range from revision of pack inserts through systematic and comprehensive information campaigns for physicians and patients to measures restricting marketing activities.

\section{Responsible approach to possible product risks}

Bayer temporarily withdrew Trasylol ${ }^{\circledR}$ from the global market in 2007 after the interim results from an independent clinical study in Canada produced evidence of a possibly increased risk of mortality in patients treated with Trasylol $^{\circledR}$. Trasylol ${ }^{\circledR}$ (active substance: aprotinin) is a drug approved for use in managing the perioperative blood loss in patients undergoing coronary artery bypass graft surgery. The marketing suspension will remain in effect until the final results from the Canadian study have been analyzed and the benefit-risk assessment for Trasylol ${ }^{\circledR}$ can be re-evaluated together with the health authorities. In some countries, including the United States, Trasylol ${ }^{\circledR}$ continues to be available to certain surgical patients with an established medical need, however. As of April 21, 2010, there were approximately 1,500 lawsuits pending in the United States and served upon Bayer as well as three class actions in Canada. Additional lawsuits are anticipated. By April 13, 2010, Bayer had reached settlement agreements with approximately 60 plaintiffs without admission of liability. Bayer will continue to consider the option of settling individual lawsuits on a case-by-case basis, but will continue to defend itself vigorously against all claims that are not considered for settlement.

In August 2009, the British Medical Journal (BMJ) published two retrospective studies on the risk of venous thromboembolism (VTE) from the use of combined oral contraceptives (COCs). These conclude that cocs have a differential risk based on the progestin component. The vTE risk when taking Yasmin ${ }^{\circledast}$ is supposedly higher than with cocs containing levonorgestrel but lower than 
with cocs containing gestoden or desogestrel. These studies and our criticism of their methodology have been reported on extensively in the media over the past few months.

We are of the opinion that both studies have significant methodological weaknesses which call the validity of their results into question. We are convinced that Yasmin ${ }^{\circledR}$ 's risk profile is comparable with those of other cocs and base our judgment in particular on two large prospective epidemiological studies on more than 120,000 women that we have sponsored after extensive discussions with health authorities in Europe and the United States. These studies conducted by independent investigators in the United States and Europe confirm that the risk of vTE is comparable in all low-dosage cocs investigated. Additional major studies are ongoing.

\section{Marketing of medicines}

We also adhere closely to provisions specified by national and international codes for the marketing of pharmaceuticals. In this connection, Bayer HealthCare has undertaken to uphold the ethical pharmaceutical advertising code of the International Federation of Pharmaceutical Manufacturers and Associations (IFPMA) and the corresponding code of the European federation EFPIA. These codes contain provisions governing, among other issues, advertising material standards, the distribution of samples, and cooperation with members of medical and pharmaceutical specialist groups in connection with consultancy contracts, studies and scientific lectures. The global and European provisions are implemented through national codes, and various points generally tightened. By recognizing the code of the association "Voluntary Self-Monitoring by the Pharmaceutical Industry" (FSA), for example, we undertake to observe strict rules governing such provisions as the implementation of drug monitoring policies or the disclosure of donations to medical institutions. In the event of discrepancies between national and international rules, we apply the more stringent code in each case.

Since 2008, furthermore, we have observed specific rules in Europe pertaining to collaboration with patient organizations and disclosed cooperation with German patient organizations beyond these obligations, including all project-related data.

\section{Analysis of pharmaceuticals in the environment}

Trace amounts of pharmaceuticals can be found in bodies of water and occasionally in drinking water. One reason for this is the excretion of pharmaceuticals and their degradation products by patients following their use. In many cases, wastewater treatment facilities reduce or degrade these substances. However, some substances are not completely removed and can thus enter natural bodies of water.

Within the scope of its product stewardship, Bayer HealthCare aims to pursue an adequate, riskbased and responsible approach to pharmaceuticals in the environment (PIE). In this connection, a special PIE working group was established to verify and deal with the effects of pharmaceuticals in the environment. We strive to keep trace elements in the soil and groundwater as low as possible and to closely monitor the risks. We conduct tests on ecotoxicity and on the dispersal and degradation behavior of our pharmaceuticals.

Bayer also participates in important research projects. A specific activity in the context of cooperation with various partners, primarily from the water resources industry, is the European PILLS project (Pharmaceutical Input and Elimination from Local Sources), which is scheduled to run from 2007 to 2011. The PILLS partnership focuses on traces of human pharmaceuticals in the context of wastewater treatment. As it seems efficient to undertake measures at high-concentra- 
Modern cultivation methods

The performance and stress resistance of plants can be increased through biotechnology. tion point sources, the collaboration focuses on the development of local treatment facilities for hospitals and nursing homes. Bayer Schering Pharma is represented in the scientific advisory committee of PILLS. Bayer's efforts in this area are focused on the treatment of wastewater resulting from the company's own production activities, with the goal of avoiding ecological risks.

\section{Quality standards in animal health}

Bayer HealthCare's Animal Health Division has marketed products for livestock and companion animals for more than 100 years. Initially, human drugs were also used in veterinary medicine. The first medicine especially developed for animals came onto the market in 1919. The division now offers over 100 different products for animal health and pest control. These products are of benefit not just to the animals themselves, but also to people, as they prevent the transmission of possible pathogens and parasites to humans. At Animal Health too, we apply high safety and quality standards to our research, development, production, marketing and distribution activities that are comparable to those in human medicine and that we observe very thoroughly. Here we also focus particularly on the environmental compatibility of our products. Through training measures and information materials, we provide veterinarians, end users and consumers with targeted details on the proper and responsible use of our products.

\section{Biotechnology - a driver of innovation}

Development and production in the area of pharmaceuticals and plant technology would be unthinkable today without the use of biotechnology. As a modern breeding method, biotechnology can help to enhance, for example, the performance potential and stress resistance of plants and thus increase crop yields. This is necessary in part to further increase the efficiency of agricultural production on limited growing acreages, which in turn enables a significant contribution to be made to feeding the growing world population. In pharmaceutical research and production as well, biotechnology has become increasingly important in recent years. Two of our best-selling products - the multiple sclerosis drug Betaferon ${ }^{\circledR} /$ Betaseron $^{\circledR}$ and the hemophilia treatment Kogenate ${ }^{\circledR}$ - are manufactured in biotechnological processes. What's more, active substances derived from the use of plants - known as "plant-made pharmaceuticals" - are tested with biological methods.

Safety is our top priority in the development and use of biotechnology. Bayer takes consumers' concerns about genetically modified organisms (GMOs) seriously and respects their right to information and freedom of choice when purchasing products. It goes without saying that we observe all relevant legal provisions. We have spelled this out in our Position on the Responsible Use of Gene Technology and in specific regulations in the subgroups and service companies. Before any product reaches market maturity, it is subjected to a stringent registration process to determine whether it is safe for people, animals and the environment.

Bayer CropScience has successfully introduced the test conditions specified by the international Excellence Through Stewardship (ETS) program - a voluntary initiative by industry - and implemented the programs and quality management processes necessary for product safety.

Bayer HealthCare has established strict production safety measures in its Directive on Biological Safety and its "Requirements for a safe handling of biological agents" procedure. 


\section{Measures to combat counterfeit products}

Counterfeit or illegally marketed pharmaceuticals or crop protection agents harbor significant risks for people and the environment due to their quality deficiencies. A total of 34 million counterfeit tablets were confiscated during inspections in the 27 E.U. Member States within two months in 2008. No one can say exactly how many counterfeit products are in circulation on which markets, as there are no reliable data on this subject. However, the large number of confiscated tablets gives a valuable picture about the extent of the danger. The rate of counterfeit products in the crop protection market lies between about 5 and 7 percent.

Bayer actively addresses product counterfeiting to minimize negative effects on the health or lives of unsuspecting patients, customers or users, as well as to protect its own competitiveness. To this end, the subgroups cooperate intensively with the responsible regulatory authorities, law enforcement agencies and customs organizations.

On its "Beware of Counterfeits" Internet site (www.vorsichtfaelschung.de - in German only), Bayer HealthCare informs patients of the considerable dangers associated with counterfeit products and provides advice on how they can protect themselves. At the European level, the company supports a proposal by the European pharmaceutical association EFPIA for coding and identifying pharmaceuticals. In this connection, manufacturers aim to ensure clear identification of pharmaceuticals upon sale to consumers through the use of a two-dimensional barcode. Between mid-September 2009 and the end of January 2010, 14 European pharmaceutical manufacturers - including Bayer HealthCare, which participated with two different products - worked with Bayer Technology Services to successfully carry out a four-month pilot project in Sweden involving around 100,000 packs. The feedback from the participating pharmacists, wholesalers and pharmaceutical manufacturers was consistently very positive.

Bayer CropScience supports the fight against illegal crop protection agents through participation in regional and global association committees such as the Anti-Counterfeiting Expert Group of the European Crop Protection Association (ECPA) and the Anti-Counterfeiting Steering Committee of CropLife International. As a result of the intensive cooperation with national and international authorities, large quantities of counterfeit crop protection agents in 2009 were confiscated in Hungary and destroyed. Bayer CropScience regularly organizes internal regional workshops to coordinate its activities to effectively counter illegal crop protection agents. Packaging materials for crop protection agents of Bayer CropScience generally feature specific identifying features that enable customers to distinguish between original and counterfeit products.

Bayer Technology Services offers a globally unique solution for the authentification of products without additional labeling: ProteXXion ${ }^{\circledR}$ is based on a laser-optic process from U.K.-based technology partner Ingenia Technology Ltd. ProteXXion ${ }^{\circledR}$ uses a laser scanner to read each individual surface of a product. This information is compared with the surface pattern of the registered original and serves as non-forgeable proof of authenticity.

Forgeries and counterfeit products not only present a risk to people and the environment, they also cause tremendous economic damage. Such piracy can impair innovation capability and competitiveness, leading to the loss of jobs and tax revenues worldwide.
Anti-counterfeiting

We are applying targeted measures in the fight against counterfeit products. 


\section{Responsible use of crop protection agents}

With its research and development efforts in the areas of crop protection, seed and plant traits, Bayer CropScience helps to safeguard and boost harvest yields worldwide. These activities necessitate extensive scientific risk assessments of crop protection agents. Stringent countryspecific regulations also apply to the registration, storage, use and disposal of such products. To ensure that these regulations are observed throughout the entire life cycle, Bayer provides all relevant product information in the

\section{Careful handling of crop protection agents}

It has long been a concern of Bayer Cropscience to train farmers across the world in the careful handling of crop protection agents. In India alone, more than 13,000 safety training sessions were held with over 720,000 farmers from more than 16,000 villages in 2009. In South America, our AgroVida program is setting standards. We have been implementing a wide range of initiatives to sensitize the village population to the importance of safety since the 1990s. In Colombia alone we trained almost 16,000 farmers in 2009 . We consider these training measures to be an integral part of our product stewardship management policy so that we become the first-choice partner for farmers - for social and ecological reasons as well. respective official national language. Currenta maintains a global emergency hotline to provide immediate assistance in the event that products are ingested orally or come into contact with the skin during use.

In addition to developing technical solutions for safe application of our products, we hold training courses worldwide for customers and partners such as farmers, dealers and medical personnel - both alone and in cooperation with CropLife International - on the proper, safe and targeted handling (product stewardship) of crop protection agents. In the emerging markets, we have mainly focused on user safety. In Europe, we have additionally concentrated on optimizing application equipment (including sowing machines) to provide better protection for users and the environment.

In 2009, Bayer CropScience published a brochure providing a comprehensive overview of its stewardship activities with 12 basic principles: from product integrity, testing, registration and labeling through production processes, application technologies, training courses, adequate packaging, transport, storage, disposal and damage prevention to protection of intellectual property. The brochure is currently available in German, English, French and Spanish. The implemented measures are based on the Food and Agriculture Organization's International Code of Conduct on the Distribution and Use of Pesticides.

\section{E.U.-wide crop protection agent requirements}

In 2009, the European Union passed two bodies of legislation governing the harmonization of registration and the sustainable use of crop protection agents in the E.U. The regulations of the new E.U. registration policy will take immediate effect in Germany from June 14, 2011, while the Directive governing the sustainable use of crop protection agents will be implemented through national laws. Bayer CropScience welcomes the E.U.'s harmonization efforts and advocates a modern registration procedure that accounts for these challenges. However, Bayer CropScience considers the result of the deliberations on crop protection legislation to be an overinterpretation of the precautionary principle as evidenced by the introduction of hazard-related exclusion criteria. These equate to a departure from the principle accepted in technology assessment and society of including in the risk assessment not just the theoretical hazard potential, but also the exposure relevant in practice. When drafting this policy, the E.U. largely neglected to carry out a comprehensive assessment of the potential long-term consequences the law would have on consumers and the environment as a result of the non-registration of important crop protection agents, which could lead to lower agricultural productivity. There is already a significant dearth of products for tackling crop diseases in the cultivation of fruits, vegetables and smaller crops. It 
is a top priority for Bayer CropScience and the European agricultural industry to enact the new legislation based on independent scientific findings, so that the desired harmonization goals can be realized in practice as intended in the national plans of action. Bayer CropScience will continue to contribute its experience and expertise in this area so as to support appropriate solutions in scientific committees and in collaboration with authorities, associations, farmers and consumer organizations. In this context, we place particular value on the further development of agricultural production systems to satisfy the increasing requirements as regards biodiversity, climate and water protection, as well as the sustainable production of high-quality, affordable food products.

\section{Gradual replacement of WHO Class I pesticides}

Bayer CropScience only distributes crop protection agents that have been granted regulatory approval by the authorities in the countries concerned, which are safe when used responsibly and as intended, and which pose no risk to either people or the environment. In streamlining its portfolio the company has committed itself to bringing products to market that have better environmental properties. As part of this strategy the portfolio is being continuously reviewed. We are accomplishing this, for example, by developing and introducing new active substances, products, application technologies and types of packaging. The portfolio was already significantly improved in recent years. The active substances discontinued during this period include methyl and ethyl parathion - we have not sold ethyl parathion in developing countries since 1992 - oxydemeton-methyl, monocrotophos, azinphos-methyl, amitraz and trichlorphon. We will discontinue the sale of products containing endosulfan worldwide by the end of 2010. New active substances with markedly better risk profiles, such as spiromesifen, flubendiamide and spirotetramate and their formulations, are now available to customers worldwide to replace the old products that have been withdrawn from the market. Bayer CropScience will systematically maintain this approach. However, there are still fields of application in which there are no suitable alternatives available. In these cases, we promote the safe use of the products in question by organizing numerous training events for users.

\section{Management of bee safety}

In the spring of 2008, Bayer CropScience made headlines because incorrectly treated corn seed resulted in the loss of bees in the Upper Rhine region of the German State of Baden-Württemberg. Investigations by both the authorities and Bayer found that the bee deaths were caused by improper application by the seed dressing companies of the crop protection agent clothianidin (trade name: Poncho ${ }^{\circledR}$ Pro) in seed treatment. Bayer CropScience has participated in the unrestricted clarification of the incidents in the Upper Rhine Valley and supports the proper use of its products through targeted dialogue with and information measures for the special interest groups affected. A corresponding multi-stage safety concept has been developed for seed dressing at the Seed Treatment Application Center in Monheim. Within the scope of this concept, training measures were carried out for employees around the world in workshops lasting for several days in order to instruct responsible parties at seed treatment companies. Furthermore, in close cooperation with sowing machine manufacturers and in coordination with the responsible registration and inspection agencies, a technical retrofitting concept for sowing machines has been developed that can considerably limit the spread of abrasive dust during the sowing of treated seed - the cause of the aforementioned incident in 2008 - through a groundlevel waste air duct. The effectiveness of these retrofitting concepts was confirmed in extensive test procedures carried out by the Julius Kühn Institute (German Federal Research Institute for Cultivated Plants). These drift minimization processes developed by Bayer CropScience in col- 
laboration with the agricultural machinery industry are setting the standard across Europe. Other regulatory authorities, such as in Austria, Slovenia, the Netherlands and also France, are already using the corresponding concepts as a guide in registration procedures. Implemented across the board, the measures developed can sustainably prevent a repeat of the incidents that took place in the Upper Rhine Valley.

While investigating the bee losses, the German Federal Office of Food Safety and Consumer Protection (BVL) in 2008 temporarily suspended marketing authorization for clothianidin-based seed treatments in the Upper Rhine region. The suspension was lifted again later in the same year for various crops with the exception of the type of corn originally affected. Bayer CropScience has submitted extensive documentation to enable assessment of the safety of clothianidin used

\section{Healthy bees}

Working together with veterinarians from Bayer Animal Health, experts from Bayer CropScience can make important contributions in bee health issues. Here, the company supports measures to reduce the risks posed to bee colonies by parasites such as the Varroa mite or other pests. We also work internationally with research institutes on matters of bee health. Bayer CropScience's contributions and activities are coordinated by a specially established team of experts focusing on bee health and product safety. as a corn seed dressing. Corresponding measures specified by the responsible authorities for sowing a type of corn seed treated with a different active substance proved their worth in the 2009 corn sowing season.

In accordance with the precautionary principle, the Italian authorities have also suspended the use of products based on neonicotinoid active substances in seed treatment. The absence of these substances and the limited options for fighting the corn rootworm have led to damages estimated at up to €90 million in Italian agriculture alone. On the other hand, clothianidin was newly or reapproved for use in corn seed treatment in Slovenia, the Netherlands and Greece in 2009 and 2010.

WWW 118 Responsible Care | 119 Global Product Strategy

120 Bayer Position on Global Product Strategy | 121 ICCA | 122 BayCare platform

123 ECHA | 124 REACH | 125 GHS | 126 LRI | 127 OECD | 128 ECETOC | 129 WHO

130 European Commission communication on the precautionary principle | 131 DFG

132 DGAUM | $133 \mathrm{VCI}$ | 134 SETAC | 135 ILSI/HESI | 136 Animal studies

137 EPAA | 138 Bayer Position on Nanotechnology | 139 CarboSafe | 140 FDA

141 EMA | 142 BfArM | 143 Trasylol | 144 IFPMA | 145 EFPIA | 146 FSA | 147 PILLS

148 Policy on gene technology | 149 Drug counterfeiting | 150 ECPA

151 CropLife International | 152 ProteXXion I 153 FAO | 154 Stewardship brochure 155 Bee safety | 156 BVL 


\section{케 ERNST \& YOUNG \\ Quality In Everything We Do}

\section{To the Management Board of Bayer AG, Leverkusen}

\section{Our engagement}

We have reviewed the parts of the Bayer Sustainable Development Report (hereinafter: the report) listed below for the reporting period from January 1, 2009 to December 31, 2009:

- Performance Report" (pages 48 to 112)

- "Health" (pages 30 to 35), "Nutrition" (pages 36 to 41) and "Climate Protection" (hereinafter referred to together as the "Focus Issues").

A review is aimed at achieving a limited level of assurance and is therefore less extensive than an audit, which is aimed at achieving reasonable assurance. Consequently, a review cannot ensure that all significant issues are identified as in an audit. Accordingly, we cannot express a conclusion in the positive form (audit opinion) on the parts of the report.

\section{Limitations of our engagement}

Our engagement did not comprise any parts of the report beyond the pages listed above. Our engagement also did not include any prospective statements or statements from external experts on pages 33,40 and 46 .

\section{Criteria}

We assessed the report against the criteria set out in the Sustainability Reporting Guidelines Vol. 3 issued by the Global Reporting Initiative and the reporting principles presented on the front flap of the report. We believe that these criteria are suitable for our assurance engagement.

\section{Responsibility of the Management Board of Bayer AG}

The Management Board of Bayer AG is responsible for the preparation and the content of the report in compliance with the above-mentioned criteria. This responsibility includes the design, implementation and maintenance of internal controls for the preparation of a report that is free from material misstatements, in accordance with the above criteria and based on suitable methods for gathering source data.

\section{Our responsibility}

Our responsibility is to issue an assurance report on the "Performance Report" and "Focus Issues" parts of the report based on our review. Our responsibility in perform- ing our assurance activities is to the management of Bayer AG only and in accordance with the terms of reference agreed with them.

We conducted our review in accordance with the International Standard on Assurance Engagements (ISAE) 3000. This standard requires that we comply with our professional duties and plan and perform the review to obtain a limited level of assurance to preclude that the "Performance Report" and "Focus Issues" parts of the report are not in accordance, in material respects, with the aforementioned reporting principles and criteria.

We performed the engagement in accordance with the independence requirements of the IFAC Code of Ethics for Professional Accountants.

\section{Procedures}

Within the scope of our engagement, we requested evidence on a sample basis based on risk and materiality criteria to obtain a limited level of assurance on the compliance of the "Performance Report" and "Focus Issues" parts of the report with the reporting principles and criteria. The nature and scope of our work was based on our professional judgment and we have performed all the procedures deemed necessary to provide a basis for our conclusions. The performance of our engagement mainly involved the following work:

- Assessment of the suitability of the underlying criteria and their consistent application.

- Inquiries of employees concerning the sustainability strategy, sustainability principles and sustainability management of Bayer AG.

- Inquiries of employees responsible for data capture and preparation of the Sustainable Development Report designed to assess the sustainable development reporting system, the data capture and compilation methods as well as internal controls to the extent relevant for a review of the Sustainable Development Report.

- Inspection of the relevant documents and systems for gathering, analyzing and aggregating data from the areas Health, Safety \& Environment (HSE) and Human Resources (HR) in the reporting period as well as tests on a sample basis. 
- Analytical considerations at Group level, subgroup level and the level of significant reporting units with regard to analysis and aggregation of HSE and HR data in the preparation of the report.

- Inquiries and inspection of documents on a sample basis relating to the collection and reporting of HSE and HR data during site visits for the following 10 reporting units: Bayer HealthCare Leverkusen (Germany), Bayer MaterialScience Leverkusen (Germany), Bayer CropScience Dormagen (Germany), Currenta Dormagen (Germany), Bayer HealthCare Grenzach (Germany), Bayer CropScience Muttenz (Switzerland), Bayer MaterialScience Caojing (China), Bayer Technology Services Caojing (China), Bayer MaterialScience Niihama (Japan) and Bayer HealthCare Orizaba (Mexico).

- Review of material qualitative statements in the "Performance Report" and the "Focus Issues" with regard to consistency and plausibility.

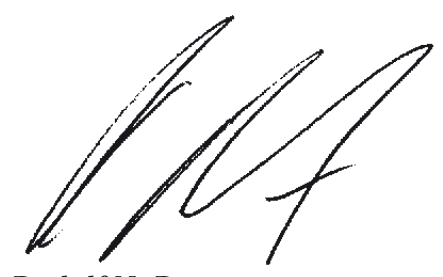

Rudolf X. Ruter

Auditor

Ernst \& Young GmbH

Wirtschaftsprüfungsgesellschaft

Düsseldorf, May 3, 2010
- Inquiries of employees from selected departments at the Group's headquarters, at subgroup level and the service companies and at the sites visited relating to significant qualitative statements made in the "Performance Report" and the "Focus Issues" as well as inspection of underlying documents.

- Review of selected press articles to ascertain whether they reflect company-specific topics of relevance for sustainable development considered in the "Performance Report" and "Focus Issues."

\section{Our conclusion}

Based on our work, nothing has come to our attention that causes us to believe that the "Performance Report" and "Focus Issues" parts of the report are not presented fairly, in material respects, in accordance with the reporting principles and criteria.

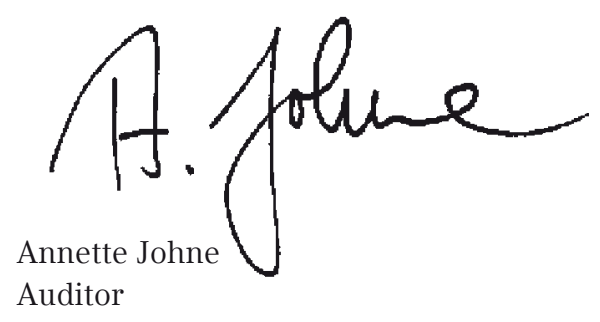




\section{Glossary}

$\underline{A}$

Acetonitrile Organic solvent African sleeping sickness Infection caused by trypanosome parasites. These are protozoa (single-cell organisms) that are transmitted by tsetse fly bites.

Aox Adsorbable organic halogen compounds; $x$ stands for the halogens fluorine, chlorine, bromine and iodine. This parameter, which is determined according to a standardized process, indicates the total level of pollution in a body of water with these organic halogen compounds, expressed in terms of chloride concentration. Organic halogen compounds are toxic and/or have poor biodegradation.

\section{B}

Beta-amyloid deposits Extensive amyloid deposits in the brain - also known as plaques - are often found in older people and are a pathological hallmark of disease in Alzheimer's patients.

Bt genes Bacillus thuringiensis are soil bacteria which form a toxic protein for harmful insects. Insect resistances in plants are thereby produced with the aid of genetic engineering processes.

\section{C}

Carbon Disclosure Leadership Index (CDLI) The Carbon Disclosure Project is an independent not-for-profit organization that collects climate-relevant information from companies on behalf of analysts and investors. The Carbon Disclosure Leadership Index (CDLI) has been published as part of the Carbon Disclosure Project since 2007. Criteria for the CDLI ranking comprise the level and quality of disclosure of climate-relevant data and reporting on long-term climate strategy, ambitious objectives and specific achievements in reducing greenhouse gas emissions.

Carbon nanotubes Carbon nanotubes, also known as CNT, are microscopic tubeshaped structures (molecular nanotubes) made of carbon.

Chagas disease Chagas (South American trypanosomiasis) is an infectious disease caused by parasites (Trypanosoma cruzi). It is transmitted to humans by so-called assassin bugs (Reduviidae). Chicago Climate Exchange (ccx) The Chicago Climate Exchange (ccX) is a voluntary greenhouse gas trading system in the United States in which 350 companies, universities and associations have undertaken to lower their joint green- house gas emissions by $6 \%$ between 2003 and 2010. Bayer Corporation is a member of the initiative.

\section{Compliance definitions}

- Corporate compliance comprises the observance of statutory and company regulations on lawful and responsible conduct by the company, its employees and its management and supervisory bodies.

- Compliance with respect to drug safety comprises the observation of regulatory requirements in quality assurance and monitoring of the risk-benefit ratio in human and veterinary medicine.

Corporate citizenship Social responsibility by companies looking to position themselves as "good citizens"

Corporate volunteering Corporate volunteering (CV) describes the support given by employers to employees looking to become civically involved in social, cultural or other projects.

D

Diversity Diversity designates the variation within the workforce in terms of gender, origin, nationality, age, religion and physical limitations.

\section{E}

EMAS EMAS is short for Eco Management and Audit Scheme, also known as E.U. Eco-Audit or Eco-Audit. It is an E.U. regulation. Introduction of EMAS is voluntary. Examples of organizations that can be certified are industrial companies, service providers and administrative centers.

Energy use (calculated in petajoules) Unit of labor, energy and heat volume ( 1 joule $=1$ watt $x$ second $=0.2239$ calories; 1 petajoule $=10^{15}$ joules)

External Adverse Incident Guideline This guideline governs global internal reporting channels in the event of unexpected incidents involving Bayer CropScience products.

$\underline{G}$

GHG Protocol The Greenhouse Gas Protocol is a standard tool for the registration and reporting of greenhouse gas emissions. The various standards summarized in the GHG Protocol were developed by the World Business Council for Sustainable Development (WBCSD) and the World Resources Institute (WRI).

GHS Globally Harmonized System for the classification, labeling and packaging of substances and mixtures; (Regulation (EC) No. $1272 / 2008)$ is in effect since January 20, 2009
Global Product Strategy Based on the objectives of the United Nations, the International Council of Chemical Associations (ICCA) took the initiative and established the Global Product Strategy (GPS). The aim of the GPS initiative is to improve and standardize the level of product stewardship in the chemical industry worldwide.

GMOs Genetically modified organisms (GMOs) are those whose hereditary disposition has been specifically altered through genetic engineering methods.

Green IT Efficiency-raising and resource-conserving measures in the information and communications technology sector for reducing greenhouse gas emissions

Green Supply Chain \& Logistics "Green supply chain" is an approach aimed at optimizing the value chain in terms of climate and cost aspects.

$\underline{\mathrm{H}}$

H1N1 Influenza virus. This influenza pathogen was first isolated in pigs. It can affect both animals and humans. It is a single-strand RNA (ribonucleic acid) virus. " $\mathrm{H} 1$ " and "N1" stand for the specific surface antigens of the virus, the hemagglutinin $\mathrm{H} 1$ and the neuraminidase $\mathrm{N} 1$.

Human biomonitoring Human biomonitoring is a tool used in environmental and occupational medicine that enables the concentrations of internal exposure to harmful substances in the environment or workplace to be determined in blood, urine or other biological material.

I

IEA The International Energy Agency (IEA) is an inter-governmental organization that advises 28 member states on energy policy issues.

Innovative Vector Control Consortium (IVCC) Initially established as a research consortium in November 2005, the Innovative Vector Control Consortium has now evolved into a Product Development Partnership (PDP). In 2008, it received the status of a not-for-profit British registered charity. The IVCC brings expertise and technical resources together with the goal of overcoming barriers to innovation in the development of new insecticides and information systems for improved vector control in health care.

Iso 14001 International standard specifying requirements for environmental management systems 
Phosphorus/Phosphate Phosphorus is a non-metal that occurs in white, red and black form. The white and red forms are insoluble in water.

Millennium Development Goals In 2000, high-ranking representatives from 189 countries adopted the Millennium Declaration at a UN summit in New York. This describes the global challenges and agenda for international politics at the beginning of the $21^{\text {st }}$ century. Eight internationally agreed objectives, the Millennium Development Goals (MDGs), were derived from the Declaration and assigned specific targets and indicators. These goals, such as eradicating poverty, maintaining peace and protecting the environment, should be achieved by 2015 . The UN is monitoring the implementation of the Millennium Declaration.

$\underline{N}$

Neonicotinoids Neonicotinoids (synthetically manufactured nicotine-like active substances) are highly effective insecticides which protect plants from biting or sucking insects when applied as sprays or seed dressings.

0

OHSAS 18001 OHSAS 18001 stands for the Occupational Health and Safety Assessment Series, which contains requirements for occupational health and safety management systems.

Open innovation approach The open innovation approach describes the optimization and opening up of the innovation processes of companies and thus the active strategic use of outside sources to expand one's own innovation potential.

Ozone-depleting substances (ODS) Ozone-depleting substances include fluorochlorohydrocarbons, other fully halogenated fluorochlorohydrocarbons, halons, tetrachlorocarbon, 1,1,1-trichloroethane, methyl bromide, partially halogenated fluorobromohydrocarbons and partially halogenated fluorochlorohydrocarbons. The successive discontinuation of their use was resolved in 1987 by the Montreal Protocol.

\section{P}

Phase I-III studies Phase I-III studies are phases in the clinical development of a drug product. The candidate active substance is tested in healthy subjects (with the exception of oncology) in Phase I, and in sick patients in Phases II and III. The studies are bound to strict legal requirements and documentation obligations. technology term designating the possibility of connecting new devices to the computer without the need to install drivers or alter settings. Contour ${ }^{\circledR}$ USB from Bayer is a Plug \& Play measuring device directly containing the diabetes data management software for the computer.

\section{Positron emission tomography (PET)}

Positron emission tomography is a nuclear medicine imaging process that produces cross-sections of living organisms by visualizing the distribution of a weakly radioactively marked substance in the organism. Depending on the selection and binding capacity of the radioactively marked substance, specific molecular structures such as receptors can thereby be made visible in vivo.

Product stewardship The monitoring of a product over its entire life cycle as an integral element of activities that satisfy the principles of sustainable development and Responsible Care

\section{$\underline{R}$}

Regulatory affairs Matters concerning the registration of pharmaceutical products

Responsible Care For the chemical industry, Responsible Care (RC) means an obligation to act responsibly. The goal is a voluntary commitment to do more than just what is prescribed: e.g. to promote sustainability, demonstrate product stewardship, increase safety for sites and the local community and improve health protection at the workplace and environmental protection.

Retrospective studies Clinical research studies that analyze previous history from the perspective of the present

\section{S}

SBCI The Sustainable Buildings and

Climate Initiative $(\mathrm{SBCI})$ is a UNEP program. The business model of the Bayer EcoCommercial Building has been included in the initiative as an innovative business model for integrated energy and material solutions ranging right up to zero-emission buildings.

Seed Treatment Application Center The Seed Treatment Application Center (STAC) in Monheim is a center of expertise for seed treatment applications technology that offers consulting, technical services, support and training for customers.
Plug \& Play Plug \& Play is a computer
Stress-induced gene (PARP-...) The poly(ADP-ribose)-polymerase gene reduces stress-induced energy consumption and protects plants against stress.

T

Telepresence A type of videoconference that enables lifelike, one-on-one communication across great distances through high-resolution communication solutions Total organic carbon (TOC) Total volume of organically bound carbon in water

$\underline{U}$

UNEP The United Nations Environment Programme was founded in 1972 and is based in Nairobi, Kenya. UNEP is a suborgan of the UN General Assembly.

\section{V}

Varroa mite Varroa mites destroy bee colonies by biting through the chitinous exoskeleton and sucking out the bees' blood.

Volatile organic compounds (voc) Volatile organic compounds are gaseous chemicals that contribute to smog or ozone formation. These enter the environment primarily from production processes, waste incineration or fuel consumption.

\section{W}

World Contraception Day This is an annual event held around the world on September 26 with the aim of increasing awareness and knowledge of contraception. It was initiated by 10 organizations to promote sexual health and family planning. The initiatives and forums are supported by the Internet site www.your-life.com 
Publisher:

Bayer AG

Communications

51368 Leverkusen

Germany

\section{Editor:}

Dr. Katrin Schneider, phone +49 2143048825

E-mail: katrin.schneider.ks@bayer-ag.de

\section{Environment \& Sustainability:}

Ursula Mathar, phone +4921430 36520

E-mail: ursula.mathar.um@bayer-ag.de

Dagmar Jost, phone +49214 3075284

E-mail: dagmar.jost.dj@bayer-ag.de

\section{English edition:}

Currenta GmbH \& Co. OHG

Language Service

\section{Bayer on the Internet:}

www.bayer.com

www.sustainability2009.bayer.com

\section{Date of publication:}

May 28, 2010

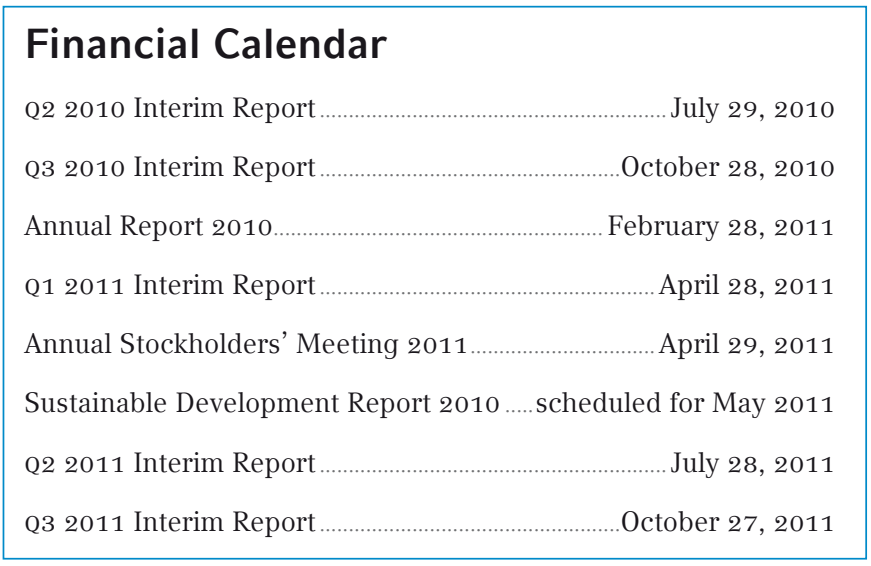

\begin{tabular}{|c|c|}
\hline 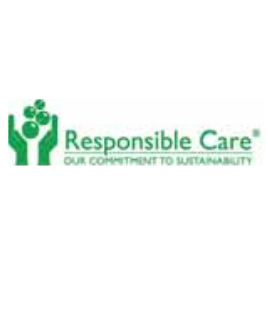 & $\begin{array}{l}\text { Bayer has a long tradition of commitment } \\
\text { to the concept of Responsible Care. } \\
\text { Since } 1994 \text {, the company has actively } \\
\text { supported the voluntary Responsible } \\
\text { Care initiative of the chemical and } \\
\text { pharmaceutical industry, including the } \\
\text { Global Charter revised in 2006, striving } \\
\text { for continuous improvement in the areas } \\
\text { of health, safety and environment. }\end{array}$ \\
\hline $\begin{array}{l}\text { World Business Council for } \\
\text { Sustainable Development }\end{array}$ & $\begin{array}{l}\text { Bayer has been a member of the } \\
\text { World Business Council for Sustainable } \\
\text { Development since } 1997 \text {. }\end{array}$ \\
\hline
\end{tabular}

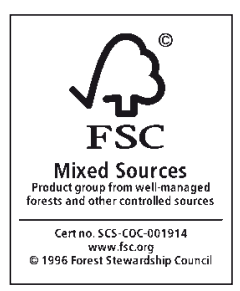

Forward-looking statements

This Sustainable Development Report may contain forward-looking statements based on current assumptions and forecasts made by Bayer Group or subgroup management. Various known and unknown risks, uncertainties and other factors could lead to material differences between the actual future results, financial situation, development or performance of the company and the estimates given here. These factors include those discussed in Bayer's public reports, which are available on the Bayer website at www.bayer.com. The company assumes no liability whatsoever to update these forward-looking statements or to conform them to future events or developments.

\section{Important information}

The names "Bayer Schering Pharma" or "Schering" as used in this publication always refer to Bayer Schering Pharma AG, Berlin, Germany, or its predecessor, Schering AG, Berlin, Germany, respectively.

Main risks from law suits

A detailed description of the main risks arising from the law suits beyond those cited in this report can be found in the Annual Report 2009. 
Index according to GRI (G3 core indicators)

Page number

Vision and strategy

1.1 Statement from the CEO or Chairman of the Supervisory Board $4 / 5$

1.2 Key sustainability impacts,

risks and opportunitie

2.1 Name of the company

2.2 Major brands, products and services

2.3 Business areas and operational structure

2.4 Location of company's headquarters

2.5 Countries in which the organization's main operations are located 13-15

2.6 Nature of ownership

2.7 Markets

2.8 Scale of the company

Significant changes during the reporting period

2.10 Awards received in the reporting period

$28 / 29,30-47,62 / 63,87 / 88$

3. Reporting parameters

\section{Reporting profile}

3.1 Reporting period

3.2 Date of most recent previous report

3.3 $\quad$ Reporting cycle

3.4 Contact for questions regarding the report

Scope and limitations of the report

3.5 Process for defining report conten

3.6 Limits of the reporting procedure

3.7 Limitations on the scope of the report

3.8 Joint ventures, subsidiaries, outsourcing

3.9 Data capture

front cover

front cover, $16 / 17$ front cover, 12-15

15, AR $144 / 145$

$12-15$

$6-10,25,47$

Changes in the pre

3.11 Changes in the scope and limitations of the report

or in the measurement methods applied

3.12 Index according to GRI with page numbers

3.13 Verification: External verification of the statements

4. Management, obligations and commitment

Management

4.1 Governance structure

4.2 Independence of the Supervisory Board Chairman

front cover

May 2009

annually

back cover

front cover, $28 / 29$

front cover, 50

front cover, 50

50

front cover, 50

front cover, 50,86

back cover

$50,113 / 114$

13,21

Governance body and/or independent members of management $13 / 14, A R 10-13$

4.4 Mechanisms for stockholders and employees to provide recommendations

to the Board of Management or Supervisory Board

4.5 Linkage between Board of Management

compensation and company performance

4.6 Mechanisms in place for the governance bodies

to ensure avoidance of conflicts of interest

14,72, AR $93-98$

4.7 Expertise of the governance bodies in sus

$59-61$

4.8 Mission statements, company values and codes of conduct

$21,26 / 27$

4.9 Procedures of the Board

for overseeing sustainability performance

4.10 Processes for evaluating the performance of the

Board of Management

Obligations towards external initiatives

4.11 Implementation of the precautionary principle

4.12 Support of external initiatives

4.13 Principal memberships in industry and business associations

Stakeholder commitment

4.14 Stakeholder groups engaged by the organization

4.15 Selection of stakeholders

4.16 Approaches to stakeholder dialogue (type/frequency)

$5,18-24,79 / 80,105,108$

4.17 Statements on key concerns raised by stakeholders

5. Performance indicators

\section{Economics}

Management approach

Aspect: Business performance

EC1 Economic value generated and distributed

EC2 Financial implications of climate change

EC3 Defined company benefit plan obligations

EC4 Public service financial benefits

Aspect: Market conduct

EC6 Business policy towards local suppliers

EC7 Senior management hired from the local community

Aspect: Indirect economic effects

EC8 Infrastructure investments and services provided for public benefit $\quad 59,84 / 85$ Ecology

Management approach

Aspect: Materials deployment

$14,19-21,24$

14,24, AR $93-98$

$18-29,62,102-112$

$29,60,63 / 64$

$8 / 29$

22,28

$28 / 29$

front cover, $18-23$

$1,18-29,30-47,51 / 52$

$12,15,54,58$

58,67

$54 / 55$

58

EN1 Materials used by weight/volume

EN2 Percentage of materials used that are recycled input materials $1,18-29,42-47,50-52,87 / 88$ Aspect: Energy use

EN3 Direct energy consumption by primary energy sources

EN4 Indirect energy consumption by primary energy sources

$88-90$

$86 / 87$

$86 / 87$
Index according to GRI (G3 core indicators)

Aspect: Water

EN8 Total water withdrawal by source

Aspect: Biodiversit

EN11 Use of land in protected areas

EN12 Significant impacts of activities in protected areas

$$
\text { Aspect: Emissions, wastewater and waste }
$$

EN16 Direct and indirect greenhouse gas emissions

EN17 Other relevant greenhouse gas emissions

(e.g. caused by business trips)

EN18 Initiatives to reduce greenhouse gas emissions and reductions achieved

EN19 Emissions of ozone-depleting substances by weigh

EN20 NOx, SOx, and other significant air emissions by weight

EN21 Wastewater discharge

EN22 Waste by type and disposal method

N23 Releases of hazardous substances by number and volume Aspect: Products and services

EN26 Initiatives to mitigate environmental impacts of products and services

EN27 Percentage of products whose packaging is reused Aspect: Legal compliance

EN28 Fines/sanctions for non-compliance with environmental regulations

Social performance

Working conditions

Management approach

Aspect: Employmen

A1 Breakdown of workforce by employment type and region

L2 Workforce fluctuation by age group, gender and region

Aspect: Codetermination

LA4 Percentage of employees covered by collective wage agreements

LA5 Minimum notice period(s) regarding significant operational changes Aspect: Occupational health and safety

A7 Injuries, absentee rates and work-related fatalities

A8 Risk control and programs with respect to serious diseases Aspect: Training and continuing education

LA10 Training and continuing education hours by employee category

LA11 Programs for employability and lifelong learning

$$
\text { Aspect: Diversity and equal opportunity }
$$

A13 Composition of senior management and employee structure (e.g. age/gender/culture)

LA14 Compensation by gender and employee category Human rights

Management approach

Aspect: Business practice

HR1 Investment decisions that include human rights clauses or screening

R2 Percentage of suppliers that have undergone screening on human rights and action taken

HR3 Employee training on human rights$$
\text { Aspect: Anti-discriminatio }
$$

HR4 Incidents of discrimination and action taken

HR5 Businesses with significant risk Aspect: Child labo

HR6 Businesses with significant risk and action taken Aspect: Forced labor

HR7 Businesses with significant risk and action taken Society

Management approach

Aspect: Local community

S01 Policy to manage impacts on local communities Policy to manage im

S02 Percentage and number of business areas analyzed

SO3 Percentage of employees trained in corruption prevention

SO4 Action taken in response to incidents of corruption

Page number

88

$92^{*}$

91

$92 / 93$

$46 / 47,92 / 93$

$94 / 95$

$87-89,95 / 96$

$97 / 98$

98-101

$42-47,102-112$

$90^{*}$

$1,18-29,51 / 52$ $66 / 67$

$66 / 67$

$76 / 77$

$75-78$

$73-75$

$72 / 73,75$

05 Public policy positions and participation

in public policy development and lobbying

S08 Fines/sanctions for non-compliance with regulations

Product stewardship

Management approach

Aspect: Customer safety and health

$1,18,22 / 23,30-41$

$18,22 / 23,80-81$

$23,80-81$ Product life cycle stages for whic

PR3 Principles/measures related to product information and labeling 102/103 Aspect: Advertising

PR6 Programs for compliance with laws

and voluntary codes related to advertising

$23,80 / 81$

$23,80 / 81$

$23,67,79$

$1,18-29,51 / 52,82$

$28 / 29,58 / 59,85$

Significant fines for non-compliance with laws and regulations concerning the use of products and services

7,11,106, AR 241ff

* Partially reported

AR=Annual Report 2009; All core indicators are included. Gaps in the numbering are due to the fact that GRI additional indicators are not included in the index.

GRI Application Level:

C $\quad \mathrm{C}+$

$\mathrm{C}+\mathrm{P}$

$\mathrm{B}+$

Reviewed by third party external organizations

Reviewed by GRI 


\section{Progress report on the implementation of the principles of the UN Global Compact}

Bayer has supported the United Nations Global Compact since this was founded in 2000. We play an active part in the endeavors to make globalization more socially and ecologically compatible and to raise standards in the fields of human rights, labor rights and environmental protection and in the fight against corruption. The following table shows the activities and management systems at Bayer that support the 10 principles of the Global Compact and the results which were achieved in the period under review. Information on the Global Compact can be found at www.unglobalcompact.org.

\begin{tabular}{|c|c|c|c|}
\hline & Systems & Measures 2009 & Achievements 2009 \\
\hline $\begin{array}{l}\text { Principle 1: } \\
\text { Support of } \\
\text { human rights }\end{array}$ & $\begin{array}{l}\text { Human Rights Position (p. 79) } \\
\text { Corporate Compliance Policy (p. 59) } \\
\text { Procurement Community Policy (p.22) } \\
\text { Procedure for selecting and evaluating } \\
\text { suppliers (p. 23, 80) } \\
\text { Supplier Code of Conduct (p. 23) }\end{array}$ & $\begin{array}{l}\text { Strategy development and expansion of the } \\
\text { alliances for sustainable health care (p.30-35) } \\
\text { and partnerships for good harvests (p.36-41) } \\
\text { Training presentation on the theme of human } \\
\text { rights (p.79) } \\
\text { Purchaser training on sustainability and on } \\
\text { the new Supplier Code of Conduct (p.23) } \\
\text { Roll-out of the Supplier Code of Conduct } \\
\text { (p.23,80) }\end{array}$ & $\begin{array}{l}\text { Increase in the Group-wide training rate } \\
\text { for human rights issues (p. 79) } \\
\text { Training rate for our purchasers world- } \\
\text { wide: almost } 100 \% \text { (p. 23) } \\
\text { First supplier training sessions for } \\
\text { the code of conduct and assessments } \\
\text { (p. } 23,80 \text { ) }\end{array}$ \\
\hline $\begin{array}{l}\text { Principle 2: } \\
\text { Exclusion of } \\
\text { human rights } \\
\text { violations }\end{array}$ & $\begin{array}{l}\text { Human Rights Position (p. 79) } \\
\text { Corporate Compliance Policy (p.59) } \\
\text { Supplier Code of Conduct (p.23) }\end{array}$ & $\begin{array}{l}\text { Start of an information campaign (brochure/ } \\
\text { training presentation) in all regions (p. 79) } \\
\text { Procurement management: risk analysis } \\
\text { using the Bayer Country Sustainability Risk } \\
\text { Index (p. 23) }\end{array}$ & \\
\hline $\begin{array}{l}\text { Principle } 3: \\
\text { Observance of the } \\
\text { right to freedom } \\
\text { of association }\end{array}$ & $\begin{array}{l}\text { Group works councils (p.66-67) } \\
\text { Bayer European Forum (p. 67) } \\
\text { Human Rights Position (p. 79) } \\
\text { Supplier Code of Conduct (p. 23) }\end{array}$ & $\begin{array}{l}\text { Constitution of union representation at Bayer } \\
\text { China (p.67) }\end{array}$ & $\begin{array}{l}\text { First supplier training sessions for } \\
\text { the code of conduct and assessments } \\
\text { (p.23,80) }\end{array}$ \\
\hline $\begin{array}{l}\text { Principle 4: } \\
\text { Abolition of all } \\
\text { forms of forced } \\
\text { labor }\end{array}$ & $\begin{array}{l}\text { Human Rights Position (p. 79) } \\
\text { Corporate Compliance organization (p. 60) } \\
\text { Supplier Code of Conduct (p.23) }\end{array}$ & $\begin{array}{l}\text { Purchaser training on sustainability and on } \\
\text { the new Supplier Code of Conduct (p.23) } \\
\text { Roll-out of the Supplier Code of Conduct } \\
\text { (p. 23, 80) }\end{array}$ & $\begin{array}{l}\text { First supplier training sessions for } \\
\text { the code of conduct and assessments } \\
\text { (p.23,80) }\end{array}$ \\
\hline $\begin{array}{l}\text { Principle 5: } \\
\text { Abolition of } \\
\text { child labor }\end{array}$ & $\begin{array}{l}\text { Human Rights Position (p. 79) } \\
\text { Corporate Compliance organization (p.60) } \\
\text { Supplier Code of Conduct (p.23) } \\
\text { Bayer Child Care Program (p. 80-81) }\end{array}$ & $\begin{array}{l}\text { Expansion of system for countering child } \\
\text { labor (p. 81) } \\
\text { Purchaser training on sustainability and on } \\
\text { the new Supplier Code of Conduct (p.23) } \\
\text { Roll-out of the Supplier Code of Conduct } \\
\text { (p.23,80) }\end{array}$ & $\begin{array}{l}\text { Brochure on child labor published (p. 81) } \\
\text { Renewed confirmation by audits that } \\
\text { there is no systematic child labor in the } \\
\text { supply chain for cotton seeds in India } \\
\text { (p. 80-81) }\end{array}$ \\
\hline $\begin{array}{l}\text { Principle 6: } \\
\text { Elimination of } \\
\text { discrimination }\end{array}$ & $\begin{array}{l}\text { Human Rights Position (p. 79) } \\
\text { Bayer diversity policy (p. 69) } \\
\text { Bayer diversity councils (p.69) } \\
\text { Corporate Compliance Policy (p.59) } \\
\text { Supplier Code of Conduct (p. 23) }\end{array}$ & $\begin{array}{l}\text { "Power of Diversity" campaign at BHC (p.69) } \\
\text { Training projects and establishment of } \\
\text { diversity councils at BCS in the United } \\
\text { States (p. 69) } \\
\text { GlobeSmart online database containing } \\
\text { information on customs and etiquette in } \\
\text { other countries (p.69) }\end{array}$ & $\begin{array}{l}\text { Continued increase in percentage of } \\
\text { women in senior management positions } \\
\text { (p.70) } \\
\text { SPEED program to support talented } \\
\text { young employees and managerial staff in } \\
\text { Asia/Pacific (p. 70) } \\
\text { Quadrupling of proportion of female } \\
\text { employees at BBS in India (p. } 70 \text { ) }\end{array}$ \\
\hline $\begin{array}{l}\text { Principle 7: } \\
\text { Precautionary } \\
\text { environmental } \\
\text { protection }\end{array}$ & $\begin{array}{l}\text { HSEQ management systems (p. 22, 51-52) } \\
\text { Risk management system (p. 62-63) } \\
\text { Global Product Strategy (p. 102) } \\
\text { Supplier Code of Conduct (p. 23) }\end{array}$ & $\begin{array}{l}\text { e.g. regular HSE(Q) audits (p. 22,52) } \\
\text { "BayRisk" procedure updated (p.62) } \\
\text { Analysis of pharmaceuticals in the environ- } \\
\text { ment (p. 107-108) } \\
\text { Training in methods of sustainable agricul- } \\
\text { ture worldwide (p.39-41) } \\
\text { Biodiversity projects (p.91-92) } \\
\text { Pilot projects for the Bayer Sustainability } \\
\text { Check (p.23) }\end{array}$ & $\begin{array}{l}\text { Successful pre-registration of more than } \\
800 \text { substances under REACH (p. 103) } \\
\text { Presentation of the CEO Safety Award } \\
\text { initiated by BMS (p.76) }\end{array}$ \\
\hline $\begin{array}{l}\text { Principle 8: } \\
\text { Specific commit- } \\
\text { ment to environ- } \\
\text { mental protection }\end{array}$ & $\begin{array}{l}\text { Group program of objectives 2006+ (p.24) } \\
\text { Bayer Sustainability Program (p.20) } \\
\text { Bayer Climate Program (p.42-47) } \\
\text { UNGC "Caring for Climate" (p.25) } \\
\text { CEO Water Mandate of the UN Global Compact } \\
\text { (p. 88) }\end{array}$ & $\begin{array}{l}\text { Application of the Bayer Climate Check } \\
\text { (p.45) } \\
\text { Implementation of the STRUCTese }{ }^{\circledR} \text { energy } \\
\text { efficiency management system (p.45) } \\
\text { Progress with the CEO Water Mandate (p. 88) } \\
\text { Green IT (resource efficiency with servers } \\
\text { and printers, p. 46) }\end{array}$ & $\begin{array}{l}\text { Reduction in greenhouse gas emissions } \\
\text { of } 6.5 \% \text { (p. } 92 \text { ) } \\
100 \text { production facilities analyzed with the } \\
\text { Bayer Climate Check (p. 45) } \\
\text { STRUCTese } \\
\text { plants (p. } 45 \text { ) } \\
\text { Reduction in emissions of carbon } \\
\text { monoxide, nitrogen oxides, sulfur oxides } \\
\text { and particulates (p.95) } \\
\text { Reduction in phosphorus discharges into } \\
\text { water (p.96) } \\
\text { Achievements with respect to the CEO } \\
\text { Water Mandate (p.88) }\end{array}$ \\
\hline $\begin{array}{l}\text { Principle 9: } \\
\text { Diffusion of } \\
\text { environmentally } \\
\text { friendly technolo- } \\
\text { gies }\end{array}$ & $\begin{array}{l}\text { Core business of BTS, BMS and Currenta } \\
\text { (p.16-17) }\end{array}$ & $\begin{array}{l}\text { Development of a new process to purify } \\
\text { acetonitrile (p. } 90 \text { ) } \\
\text { Use of non-recyclable solvents to generate } \\
\text { energy (p. 90) } \\
\text { Planning of an energy-efficient toluene diiso- } \\
\text { cyanate (TDI) production plant in Dormagen } \\
\text { (p.59) } \\
\text { Pilot plant for the environmentally compat- } \\
\text { ible utilization of } \mathrm{CO}_{2} \text { (p.57) }\end{array}$ & $\begin{array}{l}\text { Modernization of the central waste air } \\
\text { incinerator in Dormagen (p.87) } \\
\text { BAYQIK }{ }^{\otimes} \text { (quasi isothermal catalysis) } \\
\text { process for the production of sulfuric } \\
\text { acid enhances the aspects environmental } \\
\text { protection and energy recovery (p.57) }\end{array}$ \\
\hline $\begin{array}{l}\text { Principle 10: } \\
\text { Measures to fight } \\
\text { corruption }\end{array}$ & \begin{tabular}{|l} 
Corporate Compliance Policy (p. 59) \\
Code of Conduct for Responsible Lobbying \\
(p.61) \\
Code of the "Voluntary Self-Monitoring by the \\
Pharmaceutical Industry" (FSA) association (p.23) \\
Export controls (directive and manual, p.63) \\
Supplier Code of Conduct (p.23)
\end{tabular} & $\begin{array}{l}\text { Procurement management: risk analysis } \\
\text { using the Bayer Country Sustainability Risk } \\
\text { Index (p. 23) } \\
\text { Corporate compliance training (p. } 59) \\
\text { Entry in lobby register of the E.U. (p. 61) }\end{array}$ & $\begin{array}{l}\text { First supplier training sessions for the } \\
\text { code of conduct and assessments } \\
\text { (p.23, 80) } \\
\text { Use of the Bayer Country Sustainability } \\
\text { Risk Index (p. 23) }\end{array}$ \\
\hline
\end{tabular}




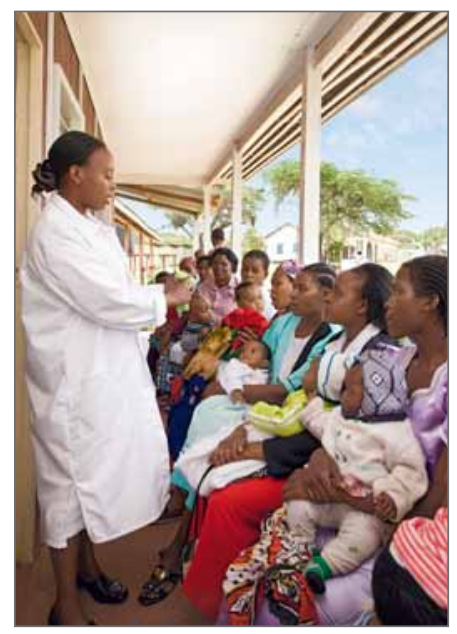

In the future, Bayer will focus even more strongly on sustainability. To this end, the company has launched an extensive program involving lighthouse projects focusing on the fields of health care, nutrition and climate protection. One of these in the health field concerns family planning. We want to help women in developing and emerging countries to take control of their own lives. A fundamental aspect of family planning is access to contraceptives. Working with partners, Bayer aims, through the provision of more health information and education, to help reduce the risks associated with unplanned pregnancies and unsafe termination of pregnancy. Our picture shows Sister Jane Maenaria, who is explaining to Kenyan women how to use oral contraceptives.

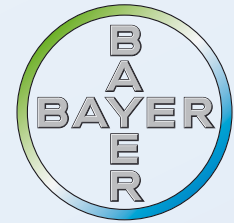

